\title{
Settling Treaty Claims: \\ The Formation of Policy on Treaty of Waitangi \\ Claims in the Pioneering Years, 1988-1998
}

Therese Suzanne Crocker

A thesis submitted to the Victoria University of Wellington in fulfilment of the requirements for the degree of

Doctor of Philosophy

Victoria University of Wellington

2016 


\section{ABSTRACT}

For the past quarter-century the New Zealand government has negotiated with Māori groupings to find ways of compensating for the Crown's historical breaches of the Treaty of Waitangi. The negotiations take place between mandated claimant negotiators and officials who represent the executive arm of government; the resultant settlements are then endorsed by legislation that declares them to be 'full and final' resolutions of historical grievances. This thesis analyses the way New Zealand governments conceived, introduced and implemented policies to address the claims during the pioneering years 1988-1998. The foundational policies worked out in this decade bedded-in the Treaty claims settlement processes which are now nearing their end. Through examining official archives, the thesis finds that these processes initially emerged as policy-driven responses to a combination of factors, such as the broad context of the 'Māori Renaissance', social shifts in understanding the past, legal cases and political pressure from iwi.

The thesis goes on to explore several years of experimental negotiations and policy formulation which culminated in the Crown's presentation in 1994 of both a suite of draft policies intended to offer a comprehensive approach to the negotiations process and a notional quantum of $\$ 1$ billion to settle all historical claims (the 'fiscal envelope'). It demonstrates that while this package was introduced to shape and contain the emergent settlement mechanisms and their outcomes, policies continued to be modified in highly significant ways. The major settlements negotiated with Waikato-Tainui and Ngāi Tahu, in particular, led to new developments which established the broad shapes of Treaty settlements, and key aspects of them, from the end of the twentieth century onwards.

Over 1988-1998, then, the Treaty settlements process transitioned from ad-hoc development of policies and arrangements into an entrenched system, yet one that was flexible enough to change in the course of negotiations with new claimant groups. 
Dedicated to

Graeme, Hannah and Jessie 


\section{REMEMBERED WITH LOVE}

‘Bob’ Robert McKenzie Craig 1921-2012

Robert 'Barry' Craig 1947-2015

Jean Margaret Yetton Brown 1931-2016 


\title{
ACKNOWLEDGEMENTS
}

\author{
He rangi tā Matawhāiti
}

He rangi tā Matawhānui

The person with a narrow vision sees a narrow horizon

The person with a wide vision sees a wide horizon

I wish to express my sincere appreciation to my supervisors Professor Richard S. Hill and Associate Professor Peter Adds, for their enthusiasm, advice and support of me. I also acknowledge the experiences of the Treaty settlements process that each of them brings. I want to thank Professor Lydia Wevers, whose experience and keen copy editing eye has been a great boost over the last few months of this process. Thanks to you all for not giving up on me, and not letting me give up either.

I am grateful to the funding from a Victoria Doctoral Scholarship and a Victoria Doctoral Submission Scholarship. A particular thanks to the Stout Research Centre administrator Debbie Levy, and former administrator Louise Grenside, who both provided much help and assistance throughout my thesis. I have thoroughly enjoyed the friendship and collegiality of the Stout community. To Justin Cargill and the distance staff, and other librarians at the Victoria University of Wellington library, thank you for your expertise and professionalism.

I would like to acknowledge those who agreed to be interviewed for this research, both on and off the record. Thank you for your time and your generosity towards me and this topic. I enjoyed our time together. I am also grateful to the staff at the Office of Treaty Settlements who facilitated my access to the files of the Treaty of Waitangi Policy Unit and the Office of Treaty Settlements. The material was invaluable to this research. 
I have been fortunate to enjoy the benefits of great discussions and encouragement from so many as I have worked on this thesis. Thanks in particular to Hazel Riseborough, who for many years has been a source of deep wisdom and friendship. To Marianna Churchward, Janine Hayward and Martin Fisher, and many others, thanks for the great discussions and your enthusiasm (for me) and this project.

To my Granny, my parents, my brothers and sisters, all my extended family and the many friends who have supported me (and our family) in so many ways over the journey of this thesis, thank you. Those who offered insight to the academic process, and those who demanded no more than my presence, I have carried you with me through this journey. I really appreciate your encouragement, hospitality, curiosity and support. It has sustained me through some long days.

It has been an absolute privilege for me to have been able to return to study to write about this area, which I am passionate about. None of this would have been possible (or worth it) without the boundless enthusiasm and love of my patient and very understanding husband Graeme Brown and our beautiful daughters Hannah and Jessie. You have all sacrificed so much for me to fulfil this goal. We did it. 


\section{CONTENTS}

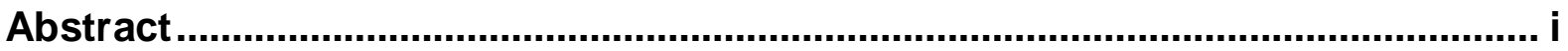

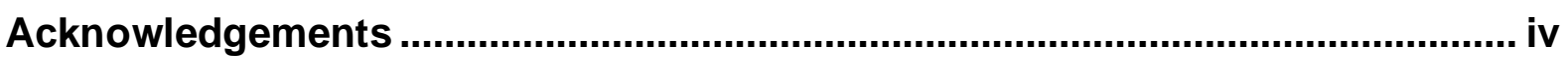

List of Abbreviations .................................................................................... ix

INTRODUCTION ................................................................................................... 1

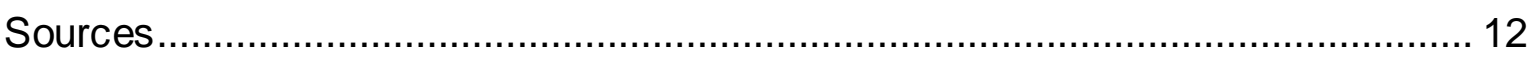

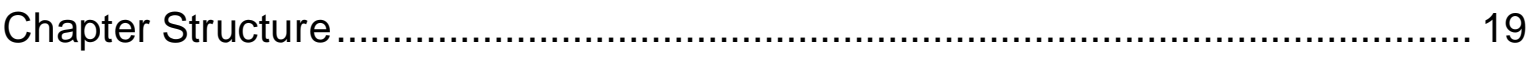

Chapter One: Looking backward to move forward .......................................... 23

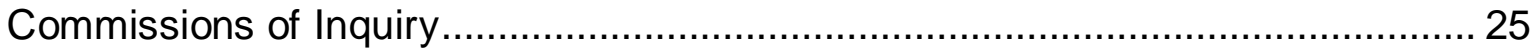

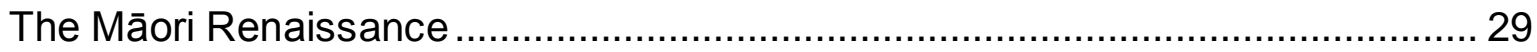

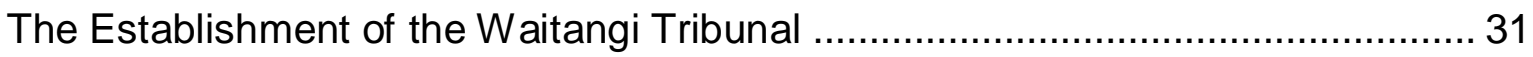

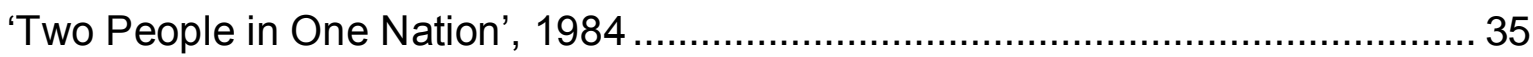

'A Catalyst for Action': The 1985 Treaty of Waitangi Amendment Act ................... 37

The Treaty in a Policy Context....................................................................... 41

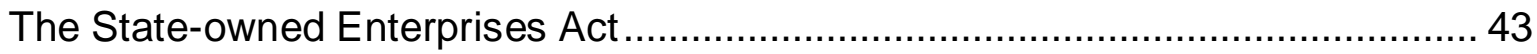

1988: The Establishment of the Treaty of Waitangi Policy Unit ............................ 46

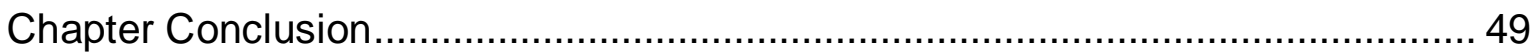

Chapter Two: 'Establishing a pattern for the future': 1989-1990 ....................... 51

The Treaty Reassessed: Court Decisions and Policy Development .................... 54

Waikato-Tainui 'Scoping Negotiations' ......................................................... 57

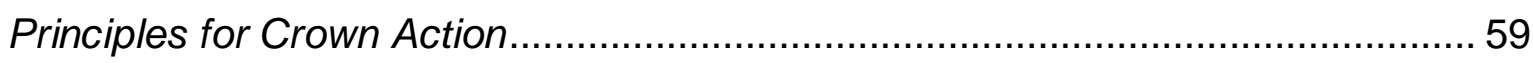

The Crown Asserts its Position on the Treaty ................................................. 64

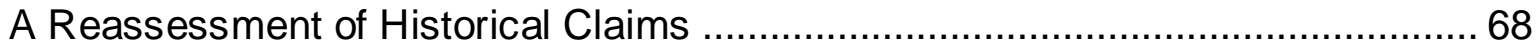

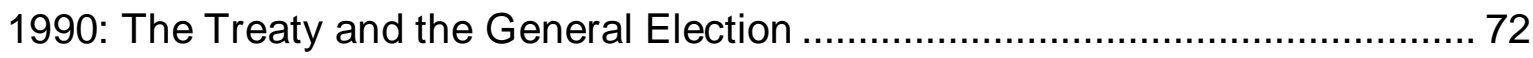

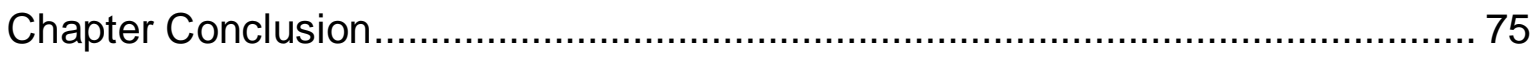

Chapter Three: Rapid Policy Development 1991-1993 ........................................ 77

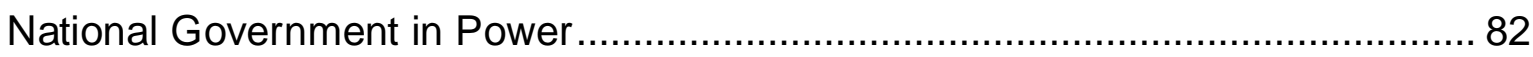

The Development of the 'Framework' Policies.............................................. 85

Historical Grievances vs Contemporary Problem-solving ................................... 88

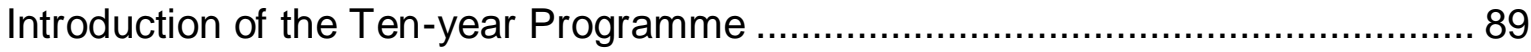


Principles for the settlement of Māori claims 91

Fisheries Agreement September 1992 ........................................................... 93

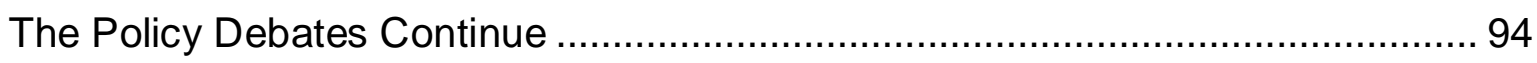

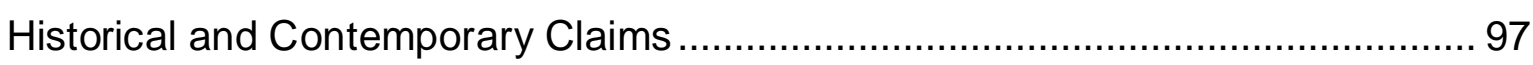

The Authority of the Tribunal and the Settlement Fund .................................... 98

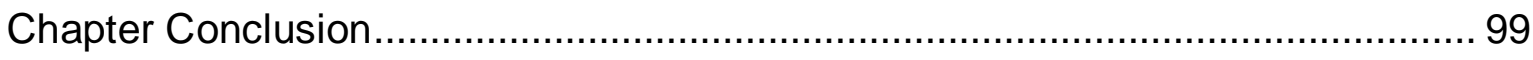

Chapter Four: Finalising the Crown Proposals 1993-1994 .............................. 101

The 1993 General Election ............................................................................ 104

The Government and the Waitangi Tribunal ............................................... 106

The Establishment of the Settlement Envelope ........................................... 108

Major Policy Developments ............................................................... 113

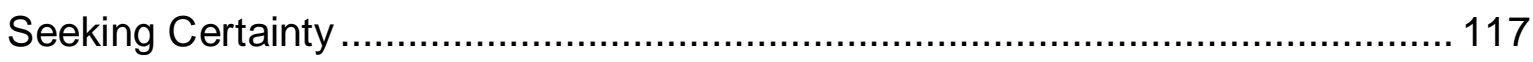

The Size of the Settlement Envelope ........................................................... 120

Planning of Consultation Process and Release of the Crown Proposals ............ 124

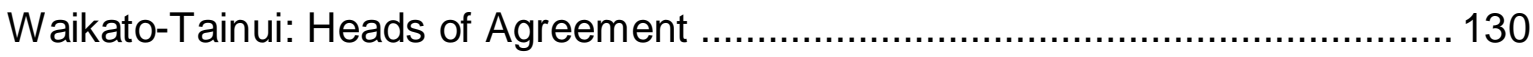

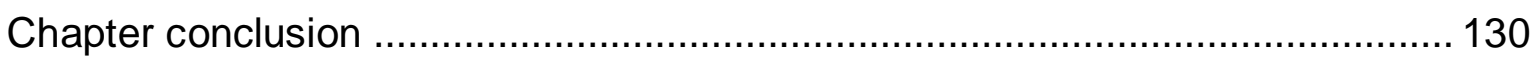

Chapter Five: After the Envelope: Reaction to the Crown Proposals............... 133

Initial Māori Response to the Crown Proposals ................................................ 136

The Hirangi Hui ..................................................................................... 137

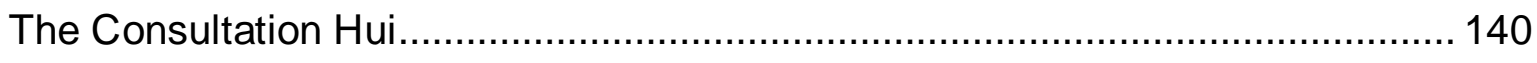

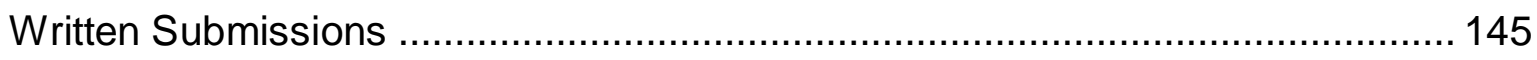

Report of Submissions, December 1995 ................................................... 147

Crown Response to the Submissions Process ................................................ 153

Chapter Conclusion........................................................................... 160

Chapter Six: From Parliament to the Paepae, policies in practice 1996 -1998 163

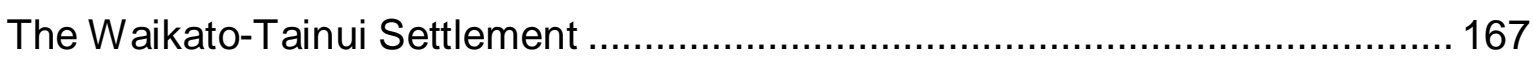

Return of Crown Land and the Development of Land-banks ............................ 169

Negotiation of the Relativity Clause for Waikato-Tainui ................................... 171

The Emergence of the Crown Apology .............................................................. 173

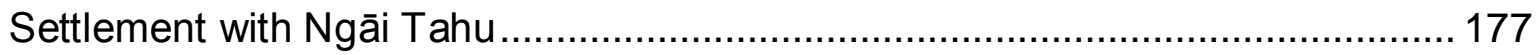

The Establishment of Te Rūnanga o Ngāi Tahu............................................... 183

Limitations of the Relativity Clause ........................................................... 184

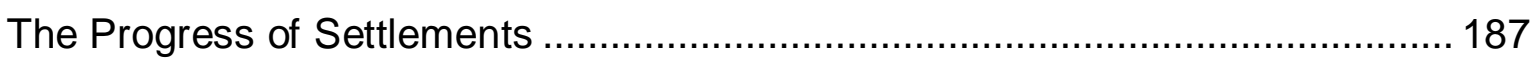




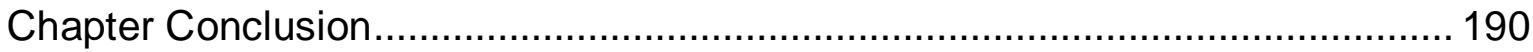

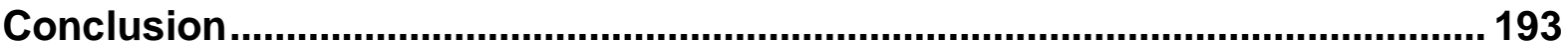

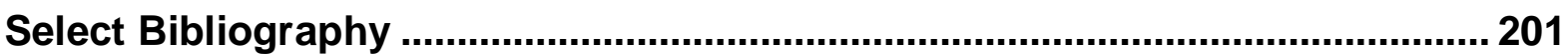




\section{LIST OF ABBREVIATIONS}

CLO

CFRT

DoC

MICOTOWN

NTMTB

OTS

OTS archive

SoE

TMTB

TOWPU

TOWPU Papers

TPK

Treasury Papers

TRONT

WT

Yellow Book
Crown Law Office

Crown Forestry Rental Trust

Department of Conservation

Minister in Charge of Treaty of Waitangi Negotiations

Ngāi Tahu Māori Trust Board

Office of Treaty Settlements

Archival material from the Treaty of Waitangi Policy Unit and the Office of Treaty Settlements, accessed from the Office of Treaty Settlements

State owned Enterprise

Tainui Maori Trust Board

Treaty of Waitangi Policy Unit

Treaty of Waitangi Policy Unit Ministerial Briefing Papers on Crown Proposals for the Settlement of Treaty of Waitangi Claims, released 31 March 1995

Te Puni Kōkiri

Treasury Advice on Crown Proposals for the Settlement of Treaty of Waitangi Claims, released 3 March 1995

Te Rūnanga o Ngāi Tahu

Waikato Tainui

Policy Papers for Crown Proposals for the Settlement of Treaty of Waitangi Claims, released 3 March 1995 


\section{INTRODUCTION}

In the past quarter of a century successive New Zealand governments have engaged with Māori to acknowledge, address, and ultimately settle historical breaches of the Treaty of Waitangi, signed in 1840. These breaches of the Treaty resulted in a variety of grievances, including the alienation of land and resources, through excessive Crown purchase, through raupatu (confiscation) of large tracts of land, the introduction of Native Land Laws, and the ongoing undermining of Māori tino rangatiratanga (in recent years described as the capacity for self-determination or autonomy). ${ }^{1}$ Since 1988 successive New Zealand governments have given priority to addressing historical breaches of Article Two of the Treaty of Waitangi through the process of negotiations between representatives of affected Māori and the Crown. ${ }^{2}$

This thesis traces the decade of rapid policy development from late 1988, when the Treaty of Waitangi Policy Unit (TOWPU) was set up, initially to provide a coordinated approach across government departments on the Treaty, through to 1998. By this time a comprehensive policy approach to settling historical Treaty claims had been established and settlements had been reached with the significant claims of both Waikato-Tainui and Ngāi Tahu. This ten year period marked a time of innovation, followed by significant and accelerated progress, by the Crown on issues of historical justice for Māori. Through years of protest, agitation, court action and the work of the Waitangi Tribunal, the Treaty had augmented to such a point in public and political consciousness that the major political parties had agreed to give a significant priority to the resolution of historical claims. What began as a tentative, ad-hoc approach developed into an established system, which forms the basis of the contemporary process. That decade was one of rapid policy development.

\footnotetext{
${ }^{1}$ For discussion see Waitangi Tribunal, The Taranaki Report: Kaupapa Tuatahi, Wai 143 (Wellington: Waitangi Tribunal, 1996), 5.

${ }^{2}$ In this thesis the Crown refers to the Executive branch of government: Ministers, government Departments and agencies and officials. For further discussion of the Crown and the role of the Crown and the Treaty of Waitangi see Janine Hayward, "In Search of a Treaty Partner: Who, or What, Is the Crown?" (PhD Thesis, Victoria University of Wellington, 1995).
} 
The Treaty of Waitangi was signed on 6 February 1840 between Māori rangatira and representatives of the British Crown. Further signatures from Māori in different parts of the country were collected over the subsequent months. There has been a significant amount of historical analysis of the Treaty and the background to its signing. ${ }^{3}$ The British version of events, that it had acquired sovereignty in exchange for Māori rights to tino rangatiratanga (expressed in Article Two's English version as guaranteeing Māori full, exclusive and undisturbed possession of their lands, forests, fisheries, and other properties as long as they wished to retain them). However, whether or not those chiefs signing the Treaty had agreed to cede to the Crown the right to govern ('kawanatanga') has been challenged by many revisionist historians and, more recently by the Waitangi Tribunal's report on the circumstances of the signings of the Treaty in Northland. ${ }^{4}$ For this thesis, and the Treaty settlement process, the important issue is that from the beginning the pledges set out in Article Two of the Treaty were violated, and that this increased over time as pressure for land grew and the balance of population shifted.

Māori sought resolution to these breaches of the Treaty, often from the time they occurred. This was pursued through a variety of means such as petitions, court cases, and direct personal deputations to England to appeal directly to Queen Victoria herself. ${ }^{5}$ But for most of New Zealand's history there were no systematic ways in which Treaty breaches could be considered or resolved. By the late 1980s, however the culmination of political and historical circumstances, and Māori assertion in the context of what has been called the 'Māori Renaissance' from the late 1960s, saw a rise in the recognition of the Treaty of Waitangi in New Zealand society. This meant that historical reconciliation could no longer be ignored. A formal process for addressing and resolving Treaty claims has developed through a process of negotiation between representatives of affected claimant groups and the Crown. This policy-driven process both began and developed significantly in the decade under study.

\footnotetext{
${ }^{3}$ A significant aspect of this is the variation in meaning between the written Māori and English versions of the Treaty. See for example Claudia Orange, The Treaty of Waitangi (Wellington: Bridget Williams Books, 2011).; Ranginui Walker, Ka Whawhai Tonu Matou: Struggle without End rev. ed. (Auckland: Penguin Books, 2004).

${ }^{4}$ See Waitangi Tribunal, He Whakaputanga Me Te Tiriti - the Declaration and the Treaty: The Report on Stage 1 of the Te Paparahi O Te Raki Inquiry (Wellington: Waitangi Tribunal, 2104).

${ }^{5}$ See for example Orange, The Treaty of Waitangi, 197-9.
} 
This thesis examines the official record (as far as possible) of the period 1988-1998, and asks what it reveals about the establishment, early development and bedding-in of the Treaty claims settlement process. It is a pioneering analysis of the way successive New Zealand governments formulated, introduced and implemented policies to address historical Treaty of Waitangi claims. In this period the Treaty settlements process transitioned from a tentative ad-hoc course to an entrenched system, which still forms the basis of the contemporary process.

The thesis is contextualised within works that argue that the Crown acts to accommodate Māori rights only when Māori led action threatens the status quo, whether that is through protest, political agitation, or through official channels, such as petitions and court action. However, in the resulting process, the authority always remains with the Crown. This is consistent with the work of other scholars, such as Ranginui Walker, Mason Durie, and Richard Hill. ${ }^{6}$ Recently Paul McHugh and Lisa Ford, have reiterated this position, arguing that politicians do not undertake a challenging and expensive programme of addressing historical colonial grievances of their own accord. They do so because they are under pressure to act. ${ }^{7}$ It was clear that the government could no longer 'do nothing' about historical Treaty issues - there was an increasing realisation that the Crown needed to act. The responses that emerged led into policies which became the basis of reconciliation through the Treaty settlement process, which is now in its final stages.

What were the circumstances in New Zealand in the late 1980s that prompted the fourth Labour government, and subsequent governments, to engage in a wideranging process of reparation with Māori? The previous decade, a number of factors, social and political had coalesced to bring the Treaty back into prominence. These included growing political awareness and consciousness-raising by diverse sections of society (such as Ngā Tamatoa and other young urban Māori, political groups, and church organisations), of the significance of the Treaty and a call for it to

\footnotetext{
${ }^{6}$ Walker, Ka Whawhai Tonu Matou: Struggle without End ; M.H. Durie, Te Māna, Te Kawanatanga: The Politics of Māori Self-Determination (Auckland: Oxford University Press, 1998); Richard S Hill, State Authority, Indigenous Autonomy in New Zealand/Aotearoa 1900-1950 (Wellington: Victoria University Press, 2004); Richard S. Hill, Maori and the State: Crown-Maori Relations in New Zealand/Aotearoa, 1950-2000 (Wellington Victoria University Press, 2009).

${ }^{7}$ Paul McHugh and Lisa Ford, "Settler Sovereignty and the Shapeshifting Crown," in Between Indigenous and Settler Governance, ed. Lisa Ford and Tim Rowse (New York: Routledge, 2013), 33.
} 
be honoured. The 1975 Māori land march was a powerful demonstration, bringing attention to the ongoing loss of Māori land and assertions of rangatiratanga.

Politically, the 1975 Treaty of Waitangi Act, which established the Waitangi Tribunal, brought the Treaty back within the legal framework. For the first time, Māori could appeal to the Tribunal for recommendations related to Crown breaches, by act or omission, of the Treaty, although any inquiries could only be from the time of the legislation onward.

Early in its term the fourth Labour government demonstrated initiatives on Treaty policy. This included an 1985 amendment to the Treaty of Waitangi Act to enable the Tribunal to investigate claims of breaches of the Treaty by the Crown back to the time of the signing of the Treaty. Some historians claim that Geoffrey Palmer, Minister of Justice, displayed naivety in leading this change, that the extent of historical claims was not appreciated and he was therefore unaware of what was going to result. ${ }^{8}$ Palmer himself has pointed out that he was well aware of the impact of what he was doing, but he noted that he could see no alternative, to deprive the Waitangi Tribunal of this greatly enlarged jurisdiction, he believed, would have meant race relations in New Zealand would go backwards. ${ }^{9}$ He has argued in a number of forums that these issues simply had to be addressed. Certainly, the Tribunal's new powers marked a decisive shift and began a new phase in New Zealand history. ${ }^{10}$ Under the responsibility of Tribunal Chairman, Chief Judge Edward Durie, the Waitangi Tribunal's investigations and findings began to establish a new bicultural jurisprudence. ${ }^{11}$

However, while the Tribunal's retrospective powers generated significant research and interest in New Zealand's colonial past, it did not actually establish a process for how such issues would actually be addressed and somehow resolved. By the late 1980s, at the very time the government was able to be held to account in its role as

\footnotetext{
${ }^{8}$ Paul Hamer, "A Quarter-Century of the Waitangi Tribunal: Responding to the Challenge," in The Waitangi Tribunal Te Roopu Whakamana I Te Tiriti O Waitangi, ed. Janine Hayward and Nicola R Wheen (Wellington: Bridget Williams Books, 2004), 5-6. The Opposition certainly claimed this at the time, 6 August 1985, NZPD, vol 465, 6063

${ }_{9}$ Interview with Sir Geoffrey Palmer, 27 February 2012

${ }^{10}$ Alan Ward, An Unsettled History: Treaty Claims in New Zealand Today (Wellington: Bridget Williams Books, 1999), 28-31.

${ }^{11}$ E. Taihakurei Durie and Gordon S. Orr, "The Role of the Waitangi Tribunal and the Development of a Bicultural Jurisprudence," New Zealand Universities Law Review 14, no. 1 (1990).
} 
Treaty partner through the Waitangi Tribunal process, it was also pursuing policy that was incompatible with this position. For example the government's scheme to corporatise Crown assets, which would be held and managed by these arms-length corporations, would for all practical purposes mean those assets were to be removed from the Crown's ownership and therefore not be available to be returned to claimants. The understanding was that as only Crown land would be potentially available as compensation for claims, Māori were looking to such land as redress for historical grievances, and now it was anticipated that large tracts would be moved out of reach of reparations processes. ${ }^{12}$ A late change to the State-owned Enterprises Bill requiring that the Crown not 'act in a manner that is inconsistent with the principles of the Treaty of Waitangi' was not sufficient to reassure Māori that Crown assets would be protected for possible return as part of a Treaty settlement. ${ }^{13}$

Māori, individually and collectively, sought to have this key issue addressed through the only course left available, the judicial system. Most notably in the New Zealand Māori Council's request for judicial review to the Court of Appeal, in what became known as the 'Lands case'. ${ }^{14}$ The Court's findings have been recognised as a landmark decision in the interpretation of the principles of the Treaty of Waitangi in a contemporary setting. ${ }^{15}$ The Court characterised the Treaty relationship as being 'akin to a partnership', and stated that the Crown must act in good faith towards Māori, as its Treaty partner (as well as vice versa). It found that the late changes made to State-owned Enterprises Act were not sufficient to safeguard Crown assets for potential use in Treaty settlements. It required the government to negotiate with Māori, the outcome of which resulted in new binding powers for the Tribunal. There were incorporated into The Treaty of Waitangi (State Enterprises) Act 1988. Under the Act State-owned Enterprises properties were marked with a protection memorial

\footnotetext{
${ }^{12}$ The one exception to this was when the Waitangi Tribunal in the Te Roroa inquiry found that a specific site should be returned to Te Roroa 'no matter the cost'. This ended up being costly matter as the land owner was obstructive and the matter proved problematic for the Crown for quite some time. The loophole of the Tribunal being able to recommend the return of the privately held land was removed with the passing of The Treaty of Waitangi Amendment Act 1993. Waitangi Tribunal, Te Roroa Report (Wai 38) (Wellington: Waitangi Tribunal, 1992), 305.

${ }^{13}$ Section 9, State-Owned Enterprises Bill, 1986

${ }^{14}$ New Zealand Maori Council v Attorney-General [1987] 1 NZLR 641. There was also a second SOE case, New Zealand Maori Council v Attorney-General [1989] 2 NZLR 142 resulting in the Crown Forest Assets Act 1989

${ }^{15}$ see Jacinta Ruru, ed. 'In Good Faith' Symposium Proceedings Marking the 20th Anniversary of the Lands Case (Dunedin: New Zealand Law Foundation and Faculty of Law, University of Otago, 2008).
} 
which ensured that if a claim on that property were well-founded the Tribunal could make a binding order for the mandatory resumption of the property to a claimant group. And although these powers have never been enforced they have been a significant factor in the government-Tribunal relationship since that time. ${ }^{16} \mathrm{~A}$ further significant case, for the evolution of the Treaty settlement process, the 'Coalcorp case', was the result of the Crown's attempt to corporatise the coal industry. The Crown argued that mining rights did not constitute an 'interest in land', meaning it was not subject to the provisions of the Treaty of Waitangi (State Enterprises) Act 1988. The Court of Appeal found in favour of the Tainui Maori Trust Board, which brought the case, and ordered that the Crown stop the sale of Coalcorp assets in the Waikato. ${ }^{17}$

It is significant that it was the fourth Labour government, holding office from July 1984 to October 1990, that simultaneously did so much to advance Treaty issues (through the amendment to the Waitangi Tribunal, and many developments after this) yet also posed the biggest potential threat to the return of assets to Māori in the future (by proposing to move Crown assets to State-owned Enterprises, to administer). ${ }^{18}$ After the court cases which resulted, the government acted to bring Treaty issues back under political control. In November 1989 Prime Minister Geoffrey Palmer announced that the government would not challenge the Court of Appeal findings in relation to Coalcorp, rather, it would set about to address historical breaches on a policy level, a process it had already long set in train. ${ }^{19}$ From this point the Labour government (and the succeeding National government) sought to develop a policy framework to address and resolve historical claims.

\footnotetext{
${ }^{16}$ Nicola R Wheen and Janine Hayward, "The Meaning of Treaty Settlements and the Evolution of the Treaty Settlement Process," in Treaty of Waitangi Settlements, ed. Nicola R Wheen and Janine Hayward (Wellington: Bridget Williams Books, 2012). 18 Barry Rigby, "Forty Years On: A Personal View of the History of the Waitangi Tribunal, 1975-2015," in Reconciliation, Representation and Indigeneity: 'Biculturalism' in Aotearoa, ed. Peter Adds, Brigitte Bönisch-Brednich, Richard S Hill and Graeme Whimp (Heidelberg: Universitätsverlag Winter, 2016 (forthcoming)).

17 Tainui Maori Trust Board V Attorney-General, 2 NZLR 513 (1989). David McCan, Whatiwhatihoe: The Waikato Raupatu Claim (Wellington: Huia Publishers, 2001), 251-96.

${ }_{18}$ The neo-liberal policies also contributed to high levels of Māori unemployment which has been an ongoing feature and contributes to issues of poverty. See Martin Holland and Jonathan Boston, ed. The Fourth Labour Government: Politics and Policy in New Zealand (Second Edition) (Auckland: Oxford University Press, 1992).

${ }_{19} 24$ November 1989, PM Geoffrey Palmer, Speech at Te Awamarahi Marae, TE131, OTS archive
} 
These, and the manner in which such policies were developed and modified over time, are the further focus of this thesis.

TOWPU had been authorised in 1988 to provide strategic policy advice. Scoping negotiations with Waikato-Tainui, in the wake of the Coalcorp issue, had begun in 1989 , the same year the government decided to consider addressing historical claims. At the time there were no precedents and certainly no budget for settlements. In July 1989 TOWPU published the government's Principles for Crown Action on the Treaty of Waitangi. The document set out five principles that would guide the Crown's actions on the Treaty: 1) The Principle of Kawanatanga or the Crown's right to govern; 2) The Principle of Rangatiratanga or the Māori right to selfmanagement; 3) The Principle of Equality; 4) The Principle of Cooperation; and 5) The Principle of Redress. The fifth principle, in particular, was a breakthrough in terms of resolving historical Treaty claims, as for the first time there was acknowledgment that that Crown had a responsibility to provide a process for the resolution of Treaty grievances (whether through the 'courts, the Waitangi Tribunal, or direct negotiation'), and would provide redress for this purpose. ${ }^{20}$ Many Māori, such as academic Mason Durie, were critical that the Crown was returning 'Treaty issues to the political arena, rather than relying on the Tribunal or a court of law'. ${ }^{21}$ But Prime Minister, Palmer responded that given that the issues were political in nature the final application of the Treaty had always been with the Crown. ${ }^{22}$

The release of the Principles for Crown Action, the beginnings of exploratory discussions with Waikato-Tainui (headed by TOWPU), and other developments in that year (such as re-assessment of the historical agreements with some iwi in the 1940s and 1950s), all provided the impetus for a new focus on negotiating settlements. From this time Māori claimants were able to by-pass the Waitangi Tribunal inquiry process and negotiate directly with the Crown (within certain defined parameters); this was expected to speed up the reconciliation processes, given that Tribunal hearings took a number of years and led to negotiations in any case.

\footnotetext{
${ }^{20}$ Department of Justice, "Principles for Crown Action on the Treaty of Waitangi," (1989), 15.

${ }^{21}$ Mason Durie, Te Māna, Te Kāwanatanga: The Politics of Māori Self-Determination (Auckland: Oxford University Press, 1998), 188.

${ }_{22} 24$ November 1989, PM Geoffrey Palmer, Speech at Te Awamarahi Marae Waikato, TE131, OTS archive
} 
Individual Māori groups (iwi, hapū or wider regional groups), then, were soon able enter a formal process of 'direct negotiation' with officials representing the Crown and reporting back to ministers. The outcome of this process, as policy emerged, was to be an agreed 'full and final' settlement of all of the historical claims of each particular group. A clear process for how a claim would progress through negotiations to settlement was devised. A Canadian model formed the starting point for the process, with adaptations made for the New Zealand context. The details of the process of direct negotiations between Māori claimants and the Crown were published in September 1990. ${ }^{23}$

From 1990 through to 1992, policy development tended to emanate from ad-hoc developments in the early negotiations. As a problem was encountered a solution was quickly developed to solve it. In this process, officials were mindful of establishing a consistent approach across the different claims. The policies around claimant funding were an example of this. Cabinet accepted that claimants needed to be sufficiently funded to be able to participate in the negotiations process, and a series of policies were approved in June 1990. Policies around mandating were another significant, early example of this kind of development. It was apparent that the government needed to ensure that those negotiating, on behalf of claimants, accurately represented both the area of the claim and the claimant group, and so policy was formulated to ensure this. ${ }^{24}$

One of the results of this reactive approach was that such measures tended to become established if they proved to be viable, even if they had been temporary solutions in the first place. Policies around the retention of areas of surplus Crown land, known as 'protection mechanism', and other land-banking systems, are examples. The protection mechanism was developed as a way of retaining surplus Crown land which was identified as being relevant to a claim. The land was purchased by TOWPU from the Crown department or agency and held in a land-

\footnotetext{
${ }^{23}$ The Treaty of Waitangi Policy Unit for the Crown Task Force on Treaty of Waitangi Issues, The Direct Negotiation of Maori Claims: An Information Booklet (Wellington: Department of Justice, 1990). ${ }^{24}$ Therese Crocker, "Mandating Matters: Maori Representation and Crown Policy in the Early Treaty Settlements Processes, 1988-1998," Treaty Research Series 2013 (2013).
} 
bank for potential use as part of a settlement. ${ }^{25}$ What was not anticipated when the protection mechanism was established, was the length of time it would take to negotiate and settle the various claims. The system, introduced in a systematic fashion in 1992 thus continues to this day.

From that year the National government sought to bring under firmer control the parameters and expenses of the negotiations system, and set about developing a comprehensive approach to the process. This work took place over several years, and culminated most dramatically in the announcement of a 'settlement envelope' of $\$ 1$ billion as the total dollar amount to be set aside to settle all historical claims. The detailed outcome of this work, however, was the publication of a series of draft Crown policies, published as Crown Proposals for the Settlement of Treaty of Waitangi Claims. Both of these aspects were released to Māori and the general public simultaneously in December 1994. While the Crown Proposals were released as a part of a strategy for consultation with Māori, the settlement envelope concept and amount were presented 'for information only', without any opportunity for feedback or modification. This proved to be a public relations disaster for the government, resulting in animosity between Māori and the Crown. Māori spokespersons unanimously rejected the unilaterally imposed cap. The figure seemed too low to be able to offer sufficient compensation for all historical claims, not all of which had been received by the Waitangi Tribunal in any case. ${ }^{26}$ The release of the Crown proposals was a touchstone moment in the Crown-Māori relationship. It signified the Crown responding to Māori grievances, but in a way which fell far short of Maori expectations in terms of consultation and outcomes.

The consultation exercise, then, was dominated by anger at the fiscal envelope and its unilateral production and status. The subsequent consultation process also demonstrated some differences in approach to the Treaty between Māori and the Crown. Many Māori called for holistic discussions about the Treaty, including how

\footnotetext{
${ }^{25}$ The current market value of the land-banked properties as at 30 June 29015 was $\$ 400.141$ million (excluding GST), Office of Treaty Settlements, Te Tari Whakatau Take e pā ana ki te Tiriti o Waitangi, "12 Month Progress Report 1 July 2014 - 30 June 2015", 11

${ }^{26}$ M.H. Durie, "Proceedings of a Hui Held at Hirangi Marae Turangi," in Treaty Settlements: The Unfinished Business, ed. Geoff McLay (Wellington: Victoria University of Wellington Law Review and the New Zealand Institute of Advanced Legal Studies, 1995) ; Ward, An Unsettled History: Treaty Claims in New Zealand Today, 52.
} 
the Crown could respect rangatiratanga. The Crown however, was committed to consider only historical resolution under Article Two. As demonstrated in this thesis, the consultation process on the draft policies, which invited oral submissions at organised regional hui and through written submissions, was essentially a boxticking exercise. The vast majority of the policies included in the Crown Proposals were applied almost immediately, despite the level of opposition during the consultation process. Over time some concessions were made.

For the most part these policies had been developed by several government departments, such as the Treasury, the Crown Law Office and Te Puni Kōkiri, working together with the Treaty of Waitangi Policy Unit as the lead agency on these issues. The advice had then been considered by a Committee of Cabinet before going to Cabinet. One of the criticisms was that the policies had been devised by the Crown in isolation, meaning that any Māori input was limited to "consultation" after the event. Yet, the government argued that it had the prerogative to develop a clear and consistent approach to these issues before going public with them. Graham, later pointed out that the government did not act in isolation, as it had been actively engaged with Māori in the negotiations process. ${ }^{27}$ These differing perspectives epitomise some of the conflicting positions held over such issues.

In parallel with developing the draft policies for the Crown Proposals, direct negotiations were being undertaken on two significant claims, those of WaikatoTainui and Ngāi Tahu. In May 1995 the Crown and Waikato-Tainui signed a Deed of Settlement settling Waikato's raupatu claims. And in September $1998 \mathrm{Ngāi}$ Tahu and the Crown signed a Deed of Settlement to settle all of Ngāi Tahu's historical claims. In his recent thesis Martin Fisher has written in detail about both sets of negotiations. With unprecedented access to archives held by the Crown and by Waikato-Tainui and Ngāi Tahu, Fisher has produced the first scholarship on each set of ground-breaking negotiations. ${ }^{28}$ Some modification of the negotiations processes has occurred over time, as individual claimant groups secured new

${ }^{27}$ Douglas Graham, "Address by the Minister in Charge of Treaty of Waitangi Negotitaions " in Treaty Settlements: The Unfinished Business, ed. Geoff McLay (Wellington: NZ Institute of Advanced Legal Studies and Victoria University of Wellington Law Review, 1995), 144.

${ }_{28}$ Martin Fisher, "Balancing Rangatiratanga and Kawanatanga: Waikato-Tainui and Ngāi Tahu's

Treaty Settlement Negotiations with the Crown" (PhD Thesis, Victoria University of Wellington, 2015). 
elements in settlements. Iwi-initiated aspects of settlements, in fact, occurred from the beginning. The inclusion of a Crown apology in the Waikato-Tainui settlement, for example, was an initiative from the claimants themselves, and the wording was negotiated. This, together with relevant historical detail, was included in its Deed of Settlement, and in the legislation to enact the settlement. Since that time virtually all settlements have included a Crown apology.

These have become more detailed over time, and are generally recognised as a significant aspect of a settlement. ${ }^{29}$ In a similar way, the return of culturally significant sites, which have become known as 'cultural redress', have been modified over time. The process began when Ngāi Tahu's priorities resulted in the establishment of some cultural redress mechanisms and these have provided a starting point for subsequent settlements. This thesis stresses the development of policy on settlement components over time, in the process of the negotiations between claimants and the Crown.

The use of the relativity clause, in contrast, was not continued after the two pioneering settlements. Late in the Waikato-Tainui negotiations process it was agreed that the iwi's settlement would be $\$ 170$ million, or 17 percent of the newly announced settlement envelope. Waikato-Tainui had sought assurance from the Crown that should the amount spent on settlements prove to be more than $\$ 1$ billion it would not be disadvantaged vis a vis other claimants. The relativity clause, therefore, provides that if the total spent on historical Treaty settlements exceeded $\$ 1$ billion in 1994 present value terms the iwi were entitled to a top-up amounting to 17 percent of the real value of settlements. Ngāi Tahu also negotiated a relativity clause in its settlement, signed in 1998. These clauses, in turn, might be said to have provided an incentive to the Crown to operate within that $\$ 1$ billion limit, even though the settlement cap was technically abolished in 1996 (and was stated to have been eliminated again in 2000). The Crown has not agreed to any further relativity clauses in any further settlements, causing a point of tension with other

\footnotetext{
${ }^{29}$ See Maureen Hickey, "Apologies in Treaty Settlements," in Treaty of Waitangi Settlements, ed. Nicola R Wheen and Janine Hayward (Wellington: Bridget Williams Books, 2012); Therese Crocker, "Reconciliation and Resolution: The Office of Treaty Settlements and the Treaty of Waitangi Claims Process in New Zealand/Aotearoa," in Reconciliation, Representation and Indigeneity: 'Biculturalism' in Aotearoa, ed. Peter Adds, Brigitte Bönisch-Brednich, Richard S Hill and Graeme Whimp (Universitätsverlag Winter: 2016 (forthcoming)).
} 
claimants. From the Crown perspective, however, the clauses exposed it to fiscal risk. Essentially, it had done its job by contributing to two significant claimant groups, Waikato-Tainui and Ngāi Tahu, agreeing to settlements from the 'settlement envelope'.

This thesis explains how, the Treaty reconciliation system that we have today emerged from a combination of Crown policy initiatives and the early negotiations. Modifications to the process, which continue to this day, began with the WaikatoTainui and Ngāi Tahu negotiations. While there have been many critics of its limitations, it is widely seen as successful - at least compared with reconciliation systems elsewhere. ${ }^{30}$

\section{Sources}

This thesis examines the factors that contributed to the development of Crown policy in the years 1988-1998, through the examination as far as possible of key primary sources. Interviews with some key individuals engaged with the process have been used to supplement the primary record. ${ }^{31}$ The structure follows a narrative approach, with the arguments and analysis emerging from the sources themselves. Given that this is a pioneering analysis of these events and the historiography of the Treaty settlement process is still at an early stage, the details of the events, their causes and consequences, first needed to be presented in all their complexity. This topic has not yet been widely explored or considered by researchers. There is a rich store of primary documents. As most of these are not yet publicly accessible, very little of the literature to date has been able to engage with the bulk of the documentary record. ${ }^{32}$ But settling historical claims under the Treaty is a significant

\footnotetext{
${ }^{30}$ Joseph Williams, "Landmarks: 40 Years of the Treaty of Waitangi Act 1975", Presentation." Victoria University of Wellington, 12 October 2015

${ }^{31}$ I conducted formal interviews with Sir Douglas Graham former Minister in Charge of Treaty of Waitangi Negotiations and a former senior policy manager at The Office of Treaty Settlements. I also undertook informal interviews with Sir Geoffrey Palmer, former Minister of Justice and Prime Minister, and with several former Crown Officials who were actively involved in policy development and direct negotiations with Māori.

${ }_{32}$ Matthew Palmer was able to access the Cabinet files on the Treaty of Waitangi from 1971. Matthew S. R. Palmer, The Treaty of Waitangi in New Zealand's Law and Constitution (Wellington: Victoria University Press, 2008), 7. More recently Martin Fisher has accessed TOWPU and OTS files relating to the Waikato-Tainui and the Ngāi Tahu negotiations processes, Fisher, "Balancing Rangatiratanga and Kawanatanga: Waikato-Tainui and Ngāi Tahu's Treaty Settlement Negotiations with the Crown."
} 
part of recent New Zealand history, and it is now timely to begin telling the story and analysing why and how it came about. This thesis handles the issues involved from the perspective of the development of government policy. While appreciating the enormous efforts of iwi to achieve settlement, it does not pretend to provide analysis on the experiences of and the outcomes for iwi. That story remains for each individual iwi to tell.

The major primary sources for the thesis have been government documents, such as Cabinet papers and internal files of the Treaty of Waitangi Policy Unit and the Office of Treaty Settlements. The Office of Treaty Settlements allowed me access to its archives, which include those of the Treaty of Waitangi Policy Unit, which operated from 1988 until it was superseded by the Office of Treaty Settlements in 1995. ${ }^{33}$ I was able to access these archival files by requesting specific files from a database list, which included file titles and brief descriptions of the content.

Although I was as thorough as possible, this procedure meant that there was no way of knowing if all relevant material had been consulted. I also sought to access the papers of the Right Honourable Sir Douglas Graham, who was Minister of Treaty Settlements for much of this period, and the papers of Right Honourable Sir William Birch, who was Minister of Finance from 1993 to $1999 .{ }^{34}$ As required by the Cabinet Manual 2008, Archives New Zealand liaised with the relevant agencies about which information should be made available to me. ${ }^{35}$ When I was allowed access only to 'certain files subject to certain terms and conditions' I (and my supervisors) considered that the caveats placed on access were too restricting to be able to agree to, and so political papers have not been used in the thesis. ${ }^{36}$

\footnotetext{
${ }^{33}$ I signed an access agreement with the Office of Treaty Settlements in order to access their archives. One of the clauses of the agreement was that OTS was given an opportunity to see and comment on draft work prior to publication, specifically to ensure that it met the criteria of the Official Information Act. I retained complete editorial control through this process.

${ }^{34}$ Papers from the collections of the Right Honorable Sir Douglas Graham, Archives ref: AAKW, series 7812, W5105. Papers from the collection of the Right Honourable Sir William Francis Birch, Archives ref: W5105; Archives ref: AAMN 7522, W5671

${ }^{35}$ Paragraph 8.110 and 8.111 of Cabinet Manual, 2008

${ }^{36}$ Draft Confidentiality Agreement for access to Archives NZ files, 16 June 2011. For example clause 5(j) of the Agreement required the researcher to agree 'not to publish, within ten years of the Thesis being deposited in the library at the University, any articles making use of the Information or any analyses based on the Information', unless the researcher has sought express permission of the Director of OTS prior to publication.
} 
In March 1995, during the time of the consultation process on the Crown Proposals for the Settlement of Treaty of Waitangi Claims, several series of key policy and Cabinet papers were released to the public by the Office of Treaty Settlements and by the Treasury as a collated set of documents under the provisions of the Official Information Act. The resulting 'Policy Papers for Crown Proposals for the Settlement of Treaty of Waitangi Claims' is a chronological summary of Cabinet decisions on the key policy decisions relating to the 'settlement envelope' and its size and to policy proposals on issues such as natural resources and conservation estate. ${ }^{37}$ Other material was released by the Office of Treaty Settlements and the Treasury, which provides insight to the advice ministers were receiving in the lead up to Cabinet decisions on the fiscal envelope and associated policies included in the Crown Proposals for the Settlement of Treaty of Waitangi Claims, released on 8 December $1994 .{ }^{38}$

Douglas Graham (later Sir Douglas), who was Minister of Treaty Settlements from 1991-1998, has written of his experiences of this period and the tensions involved in establishing a process that had little public (and at times, especially early on, ministerial) support for acknowledging and sufficiently compensating Māori grievances. ${ }^{39}$ Graham emphasises the level of learning he and fellow ministers went through as they engaged with Māori during this period.

Historians have been analysing and providing a revisionist approach to Crown-Māori relations and Treaty history since the 1970s. An early influential work on the Treaty of Waitangi was 'Te Tiriti o Waitangi: Texts and Translations', in the New Zealand Journal of History (1972) by historian Ruth Ross. ${ }^{40}$ Ross examined the Māori and English versions of the Treaty and considered the perspectives of those involved in

\footnotetext{
37 'Policy Papers for Crown Proposals for the Settlement of Treaty of Waitangi Claims', released on 3 March 1995 [hereafter Yellow Book] It was referred to as the Yellow Book at the time if its release due to its yellow cover.

${ }^{38}$ Treaty of Waitangi Policy Unit Ministerial Briefing Papers on Crown Proposals for the Settlement of Treaty of Waitangi Claims, released 31 March 1995 (hereafter TOWPU papers); Treasury Advice on Crown Proposals for the Settlement of Treaty of Waitangi Claims, released 3 March 1995 (hereafter Treasury Papers)

${ }^{39}$ Initially these duties were carried out under the portfolio of Minister of Justice. A new portfolio Minister in Charge of Treaty of Waitangi Negotiations (MICOTOWN) was established following the November 1993 general election. Douglas Graham, Trick or Treaty? (Wellington: Institute of Policy Studies, 1997).

${ }^{40}$ R.M. Ross, "Te Tiriti O Waitangi: Texts and Translations," New Zealand Journal of History 6, no. 2 (1972).
} 
1840. Researching and writing about the Treaty of Waitangi long before it became a prominent topic, Ross's seminal work is recognised as influencing a great deal of future scholarship. Alan Ward's A Show of Justice: Racial 'amalgamation' in nineteenth century New Zealand, also published in the early 1970s, provided a detailed approach to the annexation of New Zealand, following in the footsteps of Ian Wards' 1968 The shadow of the land: a study of British policy and racial conflict in New Zealand 1832-185. ${ }^{41}$

A groundbreaking text dedicated solely to the Treaty, The Treaty of Waitangi, was published by Claudia Orange in $1987 .^{42}$ The book, a comprehensive study of the Treaty, analysed its background and traced the status of the Treaty in New Zealand society and government over time. The final chapter, 'A Residue of Guilt: 18901987' highlighted nearly a century of both Māori and Pākehā New Zealand grappling with the significance of the Treaty of Waitangi, together with governments acknowledging a duty to the Treaty of Waitangi at the same time as breaching it. Orange has continued to update her work over time to include details on the negotiations process. ${ }^{43}$

From the late 1970s and into the 1980s New Zealand experienced what has been referred to as a 'historiographical revolution' in relation to the history of race relations. ${ }^{44}$ According to Lorenzo Veracini this process went both ways: 'New Zealand's new historiography, while certainly influenced by the changing political, social and economic contexts, was also an active factor in this transformation'. ${ }^{45}$ One result of this 'revolution', together with the sesquicentennial of the signing of the Treaty was a proliferation of accessible New Zealand history with an emphasis on the Treaty. For a time history books gained a popularity previously reserved for

\footnotetext{
${ }^{41}$ Alan Ward, A Show of Justice: Racial 'Amalgamation' in Ninteenth Century New Zealand (Canberra: Australian National University Press, 1974); Ian Wards, The Shadow of the Land: A Study of British Policy and Racial Conflict in New Zealand 1832-1852 (Wellington: Department of Internal Affairs, 1968).

${ }^{42}$ Claudia Orange, The Treaty of Waitangi (Wellington: Allen and Unwin, 1987).

${ }^{43}$ An Illustrated History of the Treaty of Waitangi (Wellington Bridget Williams Books Ltd, 2004); The Treaty of Waitangi.

${ }^{44}$ Lorenzo Veracini, Negotiating a Bicultural Past: An Historigraphical 'Revolution' in 1980s Aotearoa/New Zealand (Wellington: Treaty of Waitangi Research Unit, Victoria University of Wellington, 2001).

${ }^{45}$ Veracini, 16.
} 
novels. ${ }^{46}$ The year 1990, then one hundred and fifty years since the signing of the Treaty of Waitangi, created reflection about the journey to nationhood. The same year also marked two terms of a Labour government that had altered the political landscape with major economic and social reforms. Several significant volumes were published in that year. Ranginui Walker's, Struggle Without End: Ka Whawhai Tonu Matou, published in 1990, presented the history of Aotearoa/New Zealand with a Māori kaupapa, providing a new insight into the process of colonization. ${ }^{47}$ Andrew Sharp's Justice and the Māori (1990), provided analysis of the increasing demands by Māori for justice for past wrongs, and the often contradictory view of the dominant Pākehā population. Sharp's work also provided discussion on the growing distinction between the Treaty itself and the 'principles of the Treaty', as referenced by section 6 of the Treaty of Waitangi Act 1975, section 9 of the State Owned Enterprises Act 1986, and emerging from findings of the Waitangi Tribunal. ${ }^{48}$ Sharp's second edition, published in 1997 updated events from 1990, with a further chapter 'Justice and Agency, 1989-1996'. ${ }^{49}$

Much of the writing on the Treaty and its place in contemporary New Zealand has tended to focus on the development, inquiries and outcomes of the Waitangi Tribunal. It is not directly applicable to the Treaty negotiations environment, which places history in a political and policy-driven sphere. ${ }^{50}$ Two further volumes which do examine the role of the State, and the various Māori interactions with the Crown in the twentieth-century (including early Treaty negotiations) are Richard Hill's companion volumes: State Authority, Indigenous Autonomy in New Zealand/Aotearoa 1900-1950 and Maori and the State: Crown-Maori Relations in

\footnotetext{
46 Jock Phillips, "Of Verandahs and Fish and Chips and Footie on Saturday Afternoon: Reflections on 100 Years of New Zealand Historiography," New Zealand Journal of History 24, no. 2 (1990): 129.

${ }^{47}$ Ranginui Walker, Ka Whawhai Tonu Matou: Struggle without End (Auckland: Penguin, 1990).

${ }^{48}$ Andrew Sharp, Justice and the Māori: Māori Claims in New Zealand Political Argument in the 1980s (Auckland: Oxford University Press, 1990).

49 Justice and the Māori: The Philosophy and Practice of Māori Claims in New Zealand since the 1970s (Second Edition) (Oxford: Oxford University Press, 1997).

${ }^{50}$ See for example Giselle Byrnes, "Jackals of the Crown? Historians and the Treaty Claims Process," in Going Public: The Changing Face of New Zealand History, ed. Bronwyn Dalley and Jock Phillips (Auckland: Auckland University Press, 2001).; M.P.K. Sorrenson, "Towards a Radical Reinterpretation of New Zealand History: The Role of the Waitangi Tribunal," in Waitangi: Maori and Pakeha Perspectives on the Treaty of Waitangi, ed. I.H. Kawharu (Auckland: Oxford University Press, 1989); Jim McAloon, "By Which Standards? History and the Waitangi Tribunal," New Zealand Journal of History Vol.40 no. No.2 (2006).
} 
New Zealand/Aotearoa, 1950-2000. ${ }^{51}$ Hill's analysis of Crown-Māori relations in the second half of the twentieth century examines the tensions between Māori attempts to assert rangatiratanga and the response of the Crown to those attempts. Hill has argued that when Māori engage in the Treaty settlement process with the Crown they are looking, among other things, for Crown acknowledgement of rangatiratanga - a demand which he traces through the twentieth century, placing all Crown concessions to Māori within the context of their vigorous assertion of their rights. ${ }^{52}$

Some literature has argued that the Treaty settlements limit rangatiratanga (which the Waitangi Tribunal has termed 'autonomy') by considering Article 2, essentially property rights, in isolation from the remainder of the Treaty. ${ }^{53}$ In 1999 Alan Ward wrote of the interface between the Treaty, the creation of grievances through the implementation of policies and legislation of the nineteenth century, and the emergence of the Treaty claims process. Ward pointed to the complexity of trying to resolve historical grievances in a contemporary context and expressed concern about the limitations of the claims process, in particular, that the $\$ 1$ billion cap was too limited, and that the method of calculating the value of different claims was not fair. ${ }^{54}$ Some of the criticism of the process is aimed at the amount of money the Crown is prepared to set aside for Treaty Settlements. The sum of $\$ 1$ billion dollars in 1992 to settle all historical Treaty claims has been subject to criticism from the outset. $^{55}$ This is particularly so as the full extent of claims was not appreciated at that time. Despite such limitations, Ward concluded by recognising the overwhelming importance for New Zealand as a whole, of acknowledging our past and acting to address it in the present.

Wheen and Hayward's recent Treaty of Waitangi Settlements provides useful analysis on different aspects of the contemporary settlement process. Dean Cowie's chapter, 'The Treaty Settlement Process' is an insight into the roles of the different government departments which make up 'the Crown' within the contemporary

\footnotetext{
${ }^{51}$ Hill, State Authority, Indigenous Autonomy in New Zealand/Aotearoa 1900-1950. Hill, Maori and the State: Crown-Maori Relations in New Zealand/Aotearoa, 1950-2000.

52 Maori and the State: Crown-Maori Relations in New Zealand/Aotearoa, 1950-2000, 260.

53 Moana Jackson, "The Hirangi Hui: Broadening the Debate," Treaty Times 18 (1995).

${ }^{54}$ Ward, An Unsettled History: Treaty Claims in New Zealand Today, 174-5.

55 Durie, Te Māna, Te Kawanatanga: The Politics of Māori Self-Determination, 192; Ward, An Unsettled History: Treaty Claims in New Zealand Today, 176-77.
} 
settlement process. Cowie, a former Negotiations Manager at the Office of Treaty Settlements, writes about the current process for the stages that lead to the negotiation and settlement of a claim. This is a useful source for those outside the process to gain an understanding of what goes on when claimants sit down with the Crown. ${ }^{56}$

This thesis fits into a wider, international context. Over the past thirty or forty years settler societies, such as New Zealand have come to face the nature of their colonial pasts and reassessment of political and historical issues have led to a new interpretation of those pasts. Historical injustices have been brought to the fore, as a result of the revitalisation of indigenous peoples. Through on-going political and historical debates, the outcome in many countries has been a move to reconciliation. For New Zealand, such developments have resulted in a challenge to previously dominant views of our history and race-relations, including to accepted notions of national identity. ${ }^{57}$ Berg and Schaefer remind us that historical justice is an emerging field, and terms such as 'historical reparation' are still in flux. ${ }^{58}$

In New Zealand the Treaty settlements process is an obvious and tangible example of 'historical reparation'. The negotiation and delivery of a Crown apology is a specific and valued aspect of this. The Crown apology is a significant tool of reconciliation, particularly as a Crown apology is drafted through the representatives of a claimant group and representatives of the Crown sitting together and agreeing on wording. Maureen Hickey has written of the development of the Crown apology, and the nature of negotiations in relation to them. ${ }^{59}$ Emma Wethey, a former historian at the Office of Treaty Settlements offers a broader reading of the New

\footnotetext{
${ }^{56}$ Dean Cowie, "The Treaty Settlement Process," in Treaty of Waitangi Settlements, ed. Nicola R Wheen and Janine Hayward (Wellington: Bridget Williams Books, 2012).

${ }^{57}$ Richard S Hill and Brigitte Bönisch-Brednich, "Fitting Aotearoa into New Zealand: Politico-Cultural Change in a Modern Bicultural Nation," in Historical Justice in International Perspective: How Societies Are Trying to Right the Wrongs of the Past, ed. Manfred Berg and Bernd Schaefer (New York: Cambridge University Press, 2009).

${ }^{58}$ Manfred Berg and Bernd Schaefer, "Introduction," in Historical Justice in International Perspective: How Societies Are Trying to Right the Worngs of the Past, ed. Manfred Berg and Bernd Schaefer (New York: Cambridge University Press, 2009), 4.

59 Hickey, "Apologies in Treaty Settlements."; "Negotiating History: Crown Apologies in Historical Treaty of Waitangi Settlements," in Restorative Justice and Practices in New Zealand: Towards a Restorative Society, ed. Gabrielle Maxwell and James H Liu (Wellington: Victoria University Press, 2007).
} 
Zealand experience of the Crown apology, by putting it in context within the North American and Australian practice. ${ }^{60}$

\section{Chapter Structure}

The first chapter of this thesis examines some of the historical background to the current Treaty of Waitangi Settlement process. It analyses key events from the 1920s through to the 1980s, a period which provides the context to the establishment of the Treaty of Waitangi settlement process. Government policy on Māori issues was transformed during these decades. In the 1920s two commissions of inquiry were established to inquire into historical alienation of land through Crown purchase operations and through raupatu (confiscation of land) under the $1863 \mathrm{New}$ Zealand Settlements Act. ${ }^{61}$ The findings of the commissions were the basis for statutory agreements with Tainui, Taranaki and Ngāi Tahu. While the commissions and subsequent agreements recognised the impact of land loss on the respective groups they were limited in their perspectives and outcomes. This chapter discusses these limitations, while emphasising the significance that these commissions had through time.

Policies of assimilation, which had persisted for so long, were eventually superseded by a bicultural approach to policy in the 1980s. The Māori cultural and political resurgence from the late 1960s, resulting in what has commonly been called 'the Māori Renaissance', made a major contribution to this change of approach and prompted a renewed focus on the Treaty. The establishment of the Waitangi Tribunal in 1975, a permanent commission of inquiry to investigate alleged contemporary Crown breaches of the Treaty was a further example of bringing the Treaty into contemporary society and holding the Crown to account as Treaty partner. Treaty issues moved quickly in this period. In 1985 when the fourth Labour government awarded the Waitangi Tribunal retrospective powers dating back to the

\footnotetext{
${ }^{60}$ Emma Wethey, "The Politics of Apology: Issues Arising from State Apologies to Indigenous Peoples for Historical Injustices in Australasia and North America" (Thesis (M.Phil.) University of Cambridge, 2002).

${ }^{61}$ Report of Native Land Claims Commission, AJHR 1921 G5; Report of Royal Commission to inquire into confiscations of Native lands and other grievances alleged by Natives, AJHR 1928 G7
} 
signing of the Treaty, a new era was ushered in. However, there was not as yet any systematic capacity to address or implement findings of the Tribunal. The establishment of TOWPU in the Department of Justice signalled the first attempt to coordinate a government-wide response to Treaty issues, including Tribunal findings and recommendations. The nature of the work of the Unit was quickly augmented as it was called on to undertake negotiations with Waikato-Tainui in 1989.

The second chapter analyses the unprecedented political prominence of the Treaty of Waitangi in the years 1989 and 1990. This was brought about in part by the work of the Waitangi Tribunal, whose historical focus in reports was bringing attention to an often unknown aspect of New Zealand's past. ${ }^{62}$ The neo-liberal policies of the period and Treaty issues ran parallel, and the government was being forced to address the Treaty on an unprecedented level following previous judicial findings which had broken new ground on the duty of the Crown as Treaty partner; the Lands case and the Coalcorp case are discussed in detail. ${ }^{63}$ It was a result of these, with ongoing Māori pressure, that the government sought to bring Treaty issues into a policy framework. In 1989 officials reassessed historical claims, and recommended a new way of approaching them, recommending that ministers needed to reconsider the previous 'full and final' settlements. The beginnings of a policy-driven approach to historical Treaty of Waitangi claims were beginning to emerge.

As chapter three describes, by 1992 the National government sought to develop a comprehensive approach to the negotiation and settlement of claims. It focuses on the years 1992-1993, in which significant progress was made in understanding the need for a resolution to historical grievances (even though, as is demonstrated, the number of potential claims and their extent was not yet fully grasped). The process of direct-negotiations between a claimant group and the Crown, without the need for a Waitangi Tribunal investigation, was particularly championed by Douglas Graham as the Minister of Treaty Settlements. The approach was soon supported within

\footnotetext{
${ }^{62}$ For example the Waitangi Tribunal examined some of the historical background in relation to the Manukau Report, Waitangi Tribunal, Report of the Waitangi Tribunal on the Manukau Claim, Wai 8 (Wellington, 1985). See also Report of the Waitangi Tribunal on the Waiheke Island Claim (Wai 10) (Wellington: Waitangi Tribunal, 1987); Report of the Waitangi Tribunal on the Orakei Report (Wai 9) (Wellington: Waitangi Tribunal, 1987).

${ }_{63}$ In particular New Zealand Maori Council v Attorney-General [1987] 1 NZLR; Tainui Trust Board v Attorney-General [1989] 2 NZLR 513
} 
political circles, especially when the logistics were considered. This chapter traces this key period in the conceptualising of a process for addressing Treaty claims. At the time the Waikato-Tainui negotiations were continuing and the Tribunal was preparing to report on the significant Ngāi Tahu claims in February 1991, which would also need to be addressed. This work dominated the work of relevant departments for this period.

Draft policies, which set out the structure and expectations of the process for resolving grievances, were worked on through 1994 and were released for consultation as The Crown Proposals for the Settlement of Treaty of Waitangi Claims in December 1994. ${ }^{64}$ Accompanying this was the announcement of the settlement envelope, and its $\$ 1$ billion cap. The finalising of these policies and their release is the focus of Chapter Four. The chapter demonstrates that there were differing perspectives between the various government departments on the nature and appropriate level of compensation required to address these claims, and that this led to tensions. But much of this debate occurred out of public view, as a result when the issues were finally released there was a significant backlash from Mãori on the issue of process alone - let alone the content of the proposals and the nonnegotiable announcement of the cap. Chapter Five describes the reaction to the Crown Proposals. The post-release consultation process set up by the Crown, included a series of regional hui attended by officials and ministers to hear oral submissions. Written submissions on the proposals were also invited. The chapter discusses the consultation process and examines the way the submissions were considered and analysed. It concludes that the reporting back on the submissions was of limited value and that little changed as a result of the consultation.

The final chapter highlights that the main modifications to Crown policy, in the years 1996-1998. The chapter demonstrates that it was during the actual negotiations phase, when claimants met with Crown officials and identified the main priorities for their particular claimant group, that the government modified its policies in ways in which were more acceptable to iwi. Particular focus here is on the development of land-banking systems to ensure that Crown land potentially suitable for settlements

\footnotetext{
${ }^{64}$ Office of Treaty Settlements, Crown Proposals for the Settlement of Treaty of Waitangi Claims: Detailed Proposals (Wellington: Office of Treaty Settlements, Department of Justice, 1994).
} 
was not alienated during the period of negotiations. The negotiation of Crown apology for past breaches, as first included in the Waikato-Tainui settlement in 1995; and the return of cultural redress, as included in the $1998 \mathrm{Ngāi}$ Tahu settlement are used as case studies of such policy development. These became precedents for the majority of subsequent settlements, and have tended themselves to be modified incrementally over subsequent years.

The work of Māori and the New Zealand Government to resolve past grievances progressed significantly in the years 1988-1998. At the beginning of that decade there was no formal process or budget for resolving historical grievances against the Crown, but at the end of the decade a system for redress had been firmly established and continued thereafter through to the present. How did such a tentative and ad-hoc beginning in 1988 lead to such a significant and entrenched system within 10 years? That period saw an increasing political realisation that the Crown needed to act, for a number of reasons which are explored. What began as a reactive approach gradually became a comprehensive, policy-driven process for addressing and settling claims in a systematic manner. For the most part, Māori were also motivated to achieve settlements and all major iwi groupings entered the process with awareness of the limitations. The approach was modified over time as a result of negotiation between individual claimant groups and the Crown. A great deal of the innovation and progress made in this era emerged when the Crown and an individual claimant group engaged in one on one negotiations.

While Crown policies on settlement and the settlement envelope were introduced to shape and contain the process of negotiations. The major settlements negotiated with Waikato-Tainui and Ngāi Tahu, in particular, led to new developments which established the broad shapes of Treaty settlements, these have continued to be modified in highly significant ways over time. 


\title{
CHAPTER ONE: LOOKING BACKWARD TO MOVE FORWARD
}

\author{
Me haere whakamuri, \\ kia haere whakamua
}

This whakatauki or (proverb), speaks of the need to look backward, into the past, in order to move forward in the present. It is a reminder of the importance and influence of the past in the present. An understanding of the development of the current Treaty of Waitangi claims settlement process requires one to go back in time to consider how historical grievances have been dealt with, and how the Treaty itself has been regarded through time.

Since the mid-nineteenth century Māori have sought resolution, initially with the British Crown and then the New Zealand government, to breaches of the Treaty of Waitangi. Through the nineteenth and well into the twentieth century Māori had continually and repeatedly asserted their rights through the Treaty. To Māori, Article Two of the Treaty recognised their rights of tino rangatiratanga and this put them in a partnership relationship with the Crown. ${ }^{65}$ Over time, the Crown let its responsibilities to this partnership, and to Article Two obligations drop away.

For much of the twentieth century race relations in New Zealand were constructed in an assimilation rationale; there remained an official view that it was only a matter of time before Māori society became fully integrated within the dominant Pākehā society. To a certain extent, this was a lingering reflection of the 'dying race' theory so influential at the end of the nineteenth century. Visibility also contributed to the perception. For the first half of the twentieth century Māori were predominately rural; in 193683 per cent of Māori lived rurally and this had not changed much by the time of the Second World War when by this time 74 per cent of the Māori population of

\footnotetext{
65 This interpretation was confirmed by the Lands Case in 1987, New Zealand Maori Council v Attorney-General [1987] 1 NZLR
} 
88, 000 still lived rurally. ${ }^{66}$ This was in stark comparison with 1966, by which time two thirds of Māori were living in urban settings. Twenty years later this had risen to 83 per cent of Māori dwelling in urban areas. In just 50 years, Māori underwent a migration revolution from a largely rural to a predominately urban population. Māori also continued to organise themselves socially and culturally, on their own terms; 'They sought collective autonomous power over their own destinies, in fact, even during the difficult times of the great urban migration. ${ }^{67}$ As Richard Hill points out, neither 'Crown assimilation policies nor mass urban migration, then, were able to extinguish expressions of Maori autonomy, of rangatiratanga. ${ }^{68}$ The rest of New Zealand society also underwent significant change during this same period of the 1960s to the 1990s. In general, New Zealand society became less a reflection of England, and displayed an increasing willingness to stand apart. ${ }^{69}$

The policy of assimilation in place through the nineteenth and into the twentieth century attempted to undermine Māori institutions and render tribalism irrelevant. ${ }^{70}$ Despite this Māori continued to look to the Treaty of Waitangi as a source of rights. This reached a new level in the 1960s and 1970s with the Māori renaissance and increased scrutiny of the Treaty relationship. The establishment of the Waitangi Tribunal marked a significant shift in the status; the Treaty of Waitangi, no longer an historic vestige, could be drawn on to direct the Tribunal as it considered contemporary issues and whether actions or inactions of the Crown were in breach of the principles of the Treaty of Waitangi. It took a decade before the Tribunal could use the Treaty as an instrument to examine actions of the Crown from the signing of the Treaty itself. The differences between the Māori and English texts of the Treaty, together with the need to express the Treaty in a contemporary situation have led government, the courts and the Waitangi Tribunal to express and interpret the 'spirit'

\footnotetext{
${ }^{66}$ James Belich, Paradise Reforged: A History of the New Zealanders from the 1880s to the Year 2000 (Auckland: Penguin Books (NZ) Ltd, 2001), 471.

${ }^{67}$ Bönisch-Brednich, "Fitting Aotearoa into New Zealand: Politico-Cultural Change in a Modern Bicultural Nation," 245.

${ }^{68} \mathrm{Hill}$, Maori and the State: Crown-Maori Relations in New Zealand/Aotearoa, 1950-2000, 3.

${ }^{69}$ For example anti-nuclear policy, homosexual law reform See Belich, Paradise Reforged: A History of the New Zealanders from the 1880s to the Year 2000, part 5.

${ }^{70}$ Richard S Hill, Autonomy and Authority: Rangatiratanga and the Crown in Twentieth Century New Zealand: An Overview (Wellington: Crown Forestry Rental Trust, 2000).; Alan Ward, A Show of Justice Racial 'Amalgamation' in Nineteenth Century New Zealand (Auckland: Auckland University Press, 1995).
} 
of the Treaty as Treaty principles, rather than relying on the specific wording of the 1840 text. $^{71}$

This chapter traces previous attempts to address issues of Māori grievance in the twentieth-century. In doing so, it lays the foundation for 1988, the creation of the Treaty of Waitangi Policy Unit, and the establishment of a Crown initiated process to address historical Treaty of Waitangi grievances. Early attempts to address historical grievances had been limited. They tend to assess claims on the basis of 'good governance' or what was considered fair and just treatment, as the early twentieth century commissions of inquiry demonstrate.

\section{Commissions of Inquiry}

The grievances resulting from breaches of the Treaty are many and varied, occurring almost from the time of the signing of the Treaty. They relate to issues surrounding the acquisition of land through unfair purchase and through raupatu (confiscation), resources and the undermining of Māori sovereignty. These actions include, but are not limited to, widespread raupatu or confiscation of land and the unjust initiating of war, unfair Crown land purchases, and the operation and impact of the Native land laws. ${ }^{72}$ Changes to land use also resulted in the destruction of customary food sources and other resources. Reduced access to wāhi tapu or sacred places, including urupā (burial sites) was another consequence of land alienation. As a result, Māori have retained only a fraction of the land in New Zealand. By the end of the 1930s there was very little Māori land remaining in Taranaki, Waikato, Hawkes Bay and Poverty Bay, and had been a significant loss of Māori land in the South Island, Hauraki, and Auckland. The impacts were not confined to the loss of the land itself. As Alan Ward explained:

they are also about the more subtle processes that undermined tribal control of land, and tribal control of engagement with modernity, with the loss of rangatiratanga, the loss of balance, the loss of resources, and the sense of marginalisation and alienation that has followed. The sense of marginalisation

\footnotetext{
${ }^{71}$ The principles of the Treaty have evolved over time. For further discussion of the Principles of the Treaty see J. Hayward, "Flowing from the Treaty's Words: The Principles of the Treaty of Waitangi " in The Waitangi Tribunal: Te Roopu Whakamana I Te Tiriti O Waitangi, ed. J. Hayward and N.R. Wheen (Wellington: Bridget Williams Books, 2004).

${ }^{72}$ The Office of Treaty Settlements, Ka Tika Ā Muri, Ka Tika Ā Mua: Healing the Past, Building a Future. A Guide to Treaty of Waitangi Claims and Negotiations with the Crown (Wellington: Office of Treaty Settlements, 2015), 7-13.
} 
and alienation does not show up on maps. It shows up in the statistics of unemployment, social malaise, crime, ill-health, and low educational attainment. $^{73}$

During the 1940s and 1950s a number of historical grievances were addressed, which resulted in statutory agreements between the government and several Māori groups, including Tainui, Taranaki iwi, and Ngāi Tahu to address earlier grievances. These transactions were statutory agreements arising from Court decisions and Commissions of Inquiry from the 1920s they were not simply an early version of the current Treaty of Waitangi settlement process. Both the intentions and solutions were far narrower than the contemporary approach and therefore can not be directly compared to the present process, which has the Treaty at its core. Nevertheless some attention needs to be paid to what they set out to do and whether they achieved their aims. The term 'statutory agreements', as used by Cathy Marr, acknowledges the disparity in the negotiating position between Māori and the Crown at the time, but still recognises that there was some level of understanding sought by the Crown. ${ }^{74}$ It has been suggested that these agreements represented a Crown desire to extinguish customary rights, yet Māori saw them as a way to have their rights recognised, and significantly, of maintaining a relationship with the Crown. ${ }^{75}$

Māori participation and contribution to World War I provided part of the incentive to take a fresh look at long-standing Māori land grievances. The valuable contributions of Māori soldiers were used to 'increase respect for Māori among the Pākehā public, and to increase the sense of moral debt in the minds of Pākehā politicians and officials. ${ }^{76}$ Māori politicians capitalised on the goodwill this generated to push for an official response to these grievances. There was also an official view of wanting to

\footnotetext{
${ }^{73}$ Alan Ward, National Overview: Rangahaua Whanui Series, vol. I (Wellington: Waitangi Tribunal, 1997), 11.

${ }^{74}$ Cathy Marr, "Crown Policy Towards Major Crown-Iwi Claim Agreements of the 1940s and 1950s: A Preliminary Report for the Treaty of Waitangi Policy Unit," in Treaty of Waitangi Research Unit Historical Document Series (Wellington: Treaty of Waitangi Research Unit, Stout Centre for New Zealand Studies, Victoria University of Wellington, Wellington, 2010).

${ }^{75}$ Michael Belgrave, "Negotiations and Settlements," in Treaty of Waitangi Settlements, ed. Nicola R Wheen and Janine Hayward (Wellington: Bridget Williams Books, 2012), 31.

${ }^{76}$ Belich, Paradise Reforged: A History of the New Zealanders from the 1880s to the Year 2000, 212.
} 
address these historical issues and move on. ${ }^{77}$ It took quite some time for these grievances, once recognised, to actually be addressed.

The Native Land Claims Commission (Jones Commission), headed by the Native Land Court's Chief Judge Robert Jones investigated a number of claims during 1920 and 1921, including the long-term grievances of Ngāi Tahu, which primarily related to the Crown's failure to provide allocations for landless Ngāi Tahu and for promised schools and hospitals. Although previous inquiries had found in favour of allocating further reserves to Ngāi Tahu, attempts to implement those recommendations had not been fulfilled. ${ }^{78}$ The Commission found that the Crown had not treated Ngāi Tahu in a 'liberal spirit' and recommended that compensation be paid to the iwi. ${ }^{79}$ Ngāi Tahu had always sought the return of the promised reserves. But as Marr pointed out the high demand for land post- World War 1 meant that the Commission shied away from recommending the return of land and rather monetary compensation of $£ 354,000$ was recommended. ${ }^{80}$ Despite the recommendations of the Commission, little was done to finalise the issue and it was not until late 1944, 23 years after the Jones Commission, that Parliament passed the Ngāi Tahu Claim Settlement Act. The legislation allowed for annual instalments of $£ 10,000$ per annum for 30 years be paid to Ngāi Tahu Trust Board. ${ }^{81}$

A Royal Commission, to investigate the long-standing grievances of land confiscated under the 1863 New Zealand Settlements Act, following the New Zealand Wars was established in 1926 and reported back to the House in 1928. The commission, known as the Sim Commission, was asked to investigate the confiscation of land in Taranaki, Waikato, Tauranga, Eastern Bay of Plenty, and the Kauhouroa Block, and some additional petitions and report on whether any of the confiscations were excessive in quantity, whether any of the land confiscated was of a special nature

\footnotetext{
${ }^{77}$ See Marr, "Crown Policy Towards Major Crown-Iwi Claim Agreements of the 1940s and 1950s: A Preliminary Report for the Treaty of Waitangi Policy Unit," 5.

${ }^{78}$ Report of Native Land Claims Commission, AJHR 1921 G5 ; Richard S. Hill, "Settlements of Major Maori Claims in the 1940s: A Preliminary Historical Investigation. The Ngai Tahu Grievance and Its Ramifications," (TOWPU, 1989), 5.

${ }^{79}$ AJHR $1921 \mathrm{G} 5$, p.36, The Commission also investigated petitions on other areas of the country, AJHR $1921 \mathrm{G} 5$, p.1-2

${ }^{80}$ AJHR $1921 \mathrm{G} 5, \mathrm{p} .40$

${ }^{81}$ For further discussion on limitation of the compensation see Waitangi Tribunal, The Ngai Tahu Report 1991 (Wai 27) (Wellington: Waitangi Tribunal, 1991).)
} 
and should have been excluded, whether any Māori were entitled to compensation, and whether reserves (that should have been set aside) were adequate. ${ }^{82}$

In general, the commission found that the confiscation in Taranaki and Waikato was unjust and excessive, and it recommended annual compensation be paid. ${ }^{83}$ In relation to the remaining confiscated areas, it concluded that confiscations did not exceed what was fair and just. It also found that too much time had passed since the confiscation to consider returning any land of significance. This was despite the fact that requests had been made for canoe landing sites, fishing grounds, and sacred sites including Mount Taranaki. Contemporary Treaty settlement policy now recognises that the passing of time does not diminish the effects of loss of land for Māori.

Despite the recommendations of these two major commissions that compensation for long-standing grievances should be awarded to Ngāi Tahu, Taranaki, and Waikato, it took many years for this to be implemented. Changes of government, shifting political priorities and the state of the economy all had a role in stalling the payment of the recommended compensation. This is not the place for a detailed consideration of the time taken to bring these recommendations to fruition; suffice to say the relevant iwi continued to campaign and negotiate for recognition and compensation throughout this period. After negotiating for about 15 years, in 1946 agreement was reached that Tainui would receive $£ 5000$ compensation a year for 30 years. The payment was to be managed by the Tainui Maori Trust Board, established by the Waikato-Maniapoto Māori Claims Settlement Act $1946 .{ }^{84}$ Compensation for Taranaki was awarded through the 1944 Taranaki Maori Claims Settlement Act. The Act provided simply for an annual payment to the Trust Board of $£ 5000$ and a one-off payment of $£ 300$ for Parihaka. ${ }^{85}$ These agreements were described as being 'a full settlement and discharge' of the claims. Implicit in these

\footnotetext{
${ }^{82}$ Report of Royal Commission to inquire into confiscations of Native lands and other grievances alleged by Natives, AJHR 1928 G7, p.2

83 This included compensation for Whakatōhea, for 'loyal' Māori in the Wairoa district, and a one-off payment for the Parihaka raid.

${ }^{84}$ Hill, State Authority, Indigenous Autonomy in New Zealand/Aotearoa 1900-1950, 223-24.

${ }^{85}$ Hill, State Authority, Indigenous Autonomy in New Zealand/Aotearoa 1900-1950, 221.
} 
arrangements was an ongoing political belief that Māori would put the past behind them and better adjust into Pākehā society. ${ }^{86}$

But from the time of these agreements there was some ambiguity as to whether the payments were compensation for wrongful Crown actions or for land loss and associated economic impacts. The government remained determined that the settlements would be regarded as 'full and final'. Māori at least, continued to see the payments (as Ngata had presented them) as permanent acknowledgement of a wrong and that the value of the loss of land was still a matter to be settled. And as Cathy Marr points out '[A]ll sides were aware that iwi had always maintained the rights of a new generation to renegotiate. ${ }^{187}$ Some detractors of the current Treaty settlement process have been critical of what they consider 'another round' of 'full and final' settlements. ${ }^{88}$ Yet, as Cathy Marr and the Waitangi Tribunal have assessed those inquiries of the 1920s had been limited in scope and many of the historical findings had been challenged. ${ }^{89}$ None of the resulting agreements were made in the context of the Treaty of Waitangi. It should also be noted that the agreements were only for a discrete number of historical grievances. There were many other Crown actions that were not even investigated at this time.

\section{The Māori Renaissance}

Internationally, the period of the late 1960s and 1970s was a time of revival and agitation for indigenous peoples around the world. The era between World War II and the 1960s was one of unprecedented industrial growth, which resulted in

\footnotetext{
${ }^{86}$ Cathy Marr, "An Overview History of the Taranaki Confiscation Claim 1920s-1980s: From the Sim Commission to the Submission of Taranaki Claims to the Waitangi Tribunal, Wai 143," (Wellington: Waitangi Tribunal, 1993), 6.

87 "Crown Policy Towards Major Crown-Iwi Claim Agreements of the 1940s and 1950s: A Preliminary Report for the Treaty of Waitangi Policy Unit," 62.

${ }^{88}$ See for example Stuart C Scott, The Travesty of Waitangi: Towards Anarchy (Dunedin: Campbell Press, 1995).; Ian Wishart, The Great Divide: The Story of New Zealand and Its Treaty (Auckland: Howling at the Moon, 2012). For further discussion see Richard S. Hill, "Anti-Treatyism and AntiScholarship: An Analysis of Anti-Treatyist Writings," in Occasional Paper Series (Wellington: Treaty of Waitangi Research Unit, 2002).

${ }^{89}$ Marr, "Crown Policy Towards Major Crown-Iwi Claim Agreements of the 1940s and 1950s: A Preliminary Report for the Treaty of Waitangi Policy Unit."; Tribunal, The Taranaki Report: Kaupapa Tuatahi, Wai 143, sec 1.8.
} 
pressure on resources and land occupied by indigenous peoples. ${ }^{90}$ The release of an official report on the Department of Maori Affairs by Deputy Chair of the Public Service Commission and Acting Secretary for Māori, J.K. Hunn, was a key event in the growing awareness of Māori land loss and rights during this period. The Hunn report presented a situation of inevitable Māori integration, and to speed this up the report advocated the assisted urbanisation of Māori through a relocation programme. ${ }^{91}$ To assist with the goal of integration were initiatives to remove 'legal differentiation between the races', including the abolition of the separate Māori land title system. $^{92}$ The 1967 Maori Affairs Amendment Act was part of this objective. In particular, this legislation provided for compulsory 'improvement' of Māori land (but not for general land); for the compulsory acquisition of uneconomic interests in Māori land valued under £50; and for Māori land owned by four or fewer owners to lose its status as Māori land and become general land. ${ }^{93}$ Belich describes the situation set up by these policies as volatile, 'the political fuse for an explosion of Māori radicalism had been laid. ${ }^{94}$

By the early 1970s a new era of political activism was emerging from a diverse range of influences. Many young urban Māori began to be influenced and radicalised by the plight of African Americans. Ngā Tamatoa which emerged from a young Māori leadership conference at Auckland University in 1970, is an example of this political conscious raising. ${ }^{95}$ Activism soon focussed on Māori land rights and the legacy of the Treaty of Waitangi. ${ }^{96}$ This period, in turn, set the scene for the Treaty of Waitangi settlement process. Claudia Orange notes an increased interest in activities on Waitangi Day, by both Māori and Pākehā in the 1960s and 1970s,

\footnotetext{
${ }^{90}$ Ken S. Coates, A Global History of Indigenous Peoples: Struggle and Survival (New York: Palgrave Macmillan, 2004), 226-27.

${ }^{91}$ G.V. \& H.R. Young Butterworth, Maori Affairs: A Department and the People Who Made It (Wellington: Government Printing Office, 1990), 102.

${ }^{92}$ Hill, Maori and the State: Crown-Maori Relations in New Zealand/Aotearoa, 1950-2000, 158.

${ }^{93}$ I.H. Kawharu, Maori Land Tenure: Studies of a Changing Institution (Oxford: Oxford university Press, 1977), 272-93.

${ }^{94}$ Belich, Paradise Reforged: A History of the New Zealanders from the 1880s to the Year 2000, 477. See also Donna Awatere, Maori Sovereignty (Auckland: Broadsheet, 1984).

${ }^{95}$ Walker, Ka Whawhai Tonu Matou: Struggle without End 210-12.

${ }^{96}$ Hill, Maori and the State: Crown-Maori Relations in New Zealand/Aotearoa, 1950-2000, 155. For broader discussion on Māori political activism see Aroha Harris, Hikoi: Forty Years of Maori Protest (Wellington: Huia Publishers, 2004).
} 
although perhaps motivated by different agendas. ${ }^{97}$ There was also a growing awareness of environmental issues at this time. Many of these aspects of Māori protest and agitation coalesced with the land march of 1975 from Te Hāpua in the far north to Parliament buildings in Wellington, led by kuia Whina Cooper. With the slogan of 'not 1 more acre', the land march united Māori young and old, in a strong, visible display that was not able to be ignored. McHugh described the land march as 'the moment at which the Treaty of Waitangi obtained a national profile, which it has retained ever since'. ${ }^{98}$ The 1975 land march arrived at Parliament within days of the passing of the Treaty of Waitangi Act. This was a further demonstration of the coalescing of energy and focus at this time.

\section{The Establishment of the Waitangi Tribunal}

Former Chair of the Waitangi Tribunal, the Honourable Justice Joe Williams, characterised the establishment of the Tribunal as representing a 'shift from protest to process. ${ }^{99}$ Matiu Rata, Labour-Ratana MP for Northern Māori introduced the Treaty of Waitangi Bill in his role as Minister for Māori Affairs. During the introduction of the Bill, Rata pointed out that it gave rise to Labour's election undertaking to mark Waitangi Day as a public holiday and to 'examine the practical means of legally acknowledging the principles set out in the Treaty'. ${ }^{100}$

Under the 1975 Treaty of Waitangi Act the Waitangi Tribunal was established, as a permanent commission of inquiry. It was able to inquire into and make recommendations into any claims brought by any Māori or group of Māori prejudicially affected by any Act, regulation, Order in Council, or policy or practice of the Crown which is considered inconsistent with the principles of the Treaty of Waitangi from that time onward. It was for the Tribunal to consider what the principles of the Treaty might be, taking both the Māori and English versions into

\footnotetext{
97 Orange, The Treaty of Waitangi, 226.

98 P.G. McHugh, "From Soverignty Talk to Settlement Time: The Consitutional Setting of Māori Claims in the 1990s," in Indigenous Peoples' Rights in Australia, Canada, and New Zealand, ed. Paul Havemann (Auckland: Oxford University Press, 1999), 456.

${ }^{99}$ Chief Judge J V Williams, "Speech," in 25th Anniversary of the Waitangi Tribunal conference (Wellington, 11 October 2000).

100 Matiu Rata, 8 November 1974, vol.395, NZPD, p.5725-6. Rata referred to two years work by a committee examining whether formal recognition of the Treaty principle was possible.
} 
account in equal measure. The Tribunal was then to make recommendations to government on these claims and determine the extent to which it is appropriate to redress the grievances in the present. The impact of the Act was significant, and within 'a decade, new thinking on the Treaty would bring change to almost every area of government. ${ }^{101}$ The legislation signified a new acknowledgement of the Treaty at an executive level.

Claudia Orange has suggested that 'few appreciated the full significance of this legislation. ${ }^{102}$ The Bill's sponsor, Rata, certainly did; although his vision had been to give the Tribunal retrospective powers, perhaps back to 1900. There has been some debate about why Rata was not able to convince his Cabinet colleagues to do this. Hill notes that Rata had 'attempted to persuade Cabinet that the proposed Waitangi Tribunal ought to have jurisdiction back to 1900, a compromise (based on spurious advice that historical material was lacking) from the ideal of retrospective jurisdiction back to $1840 .{ }^{103}$ He was clearly not able to convince his Cabinet colleagues. During the third reading of the Treaty of Waitangi Bill, Rata noted:

The absence of retrospective powers in this Bill was the only matter on which there was a strong difference of opinion before the Māori Affairs Committee. After considerable thought the government accepted that at this stage the complexity of the many issues involved is such that retrospective powers should not be given. ${ }^{104}$

Although clearly a milestone in recognising the role and function of the Treaty of Waitangi, the Waitangi Tribunal was initially limited in its effectiveness, mainly due to the provisions of the legislation which only allowed for inquiries on Crown actions or omissions from the passing of the Act. This immediately limited the claims that could be registered to contemporary actions of the Crown. It was not able to consider the many historical impacts of colonisation. The early claims registered reflected the contemporary interface between Māori and the Crown; registered claims related to fisheries rights and regulations, the establishment of a power station, and the impact of pollution on waterways. ${ }^{105}$ The fact that the Tribunal only

\footnotetext{
101 Orange, The Treaty of Waitangi, 230.

102 Ibid.

${ }^{103}$ Hill, Maori and the State: Crown-Maori Relations in New Zealand/Aotearoa, 1950-2000, 165.

${ }^{104}$ Matiu Rata, 10 October 1985, NZPD, Vol.402, p.5407

${ }^{105}$ Five of the first six claims registered reflected these concerns; Wai 1 Claim by J.P. Hawke and Others of Ngati Whatu concerning the fisheries regulations; Wai 2 Claim on the Waiau Pa Power
} 
had powers of recommendation was also criticised. Over time the Tribunal's measured recommendations have proved to be a powerful incentive to government, but in the early years, there was growing disquiet about the Tribunal as just another example of government 'window dressing'. ${ }^{106}$ The first Tribunal was seen as being limited in its make-up and monocultural in its approach and this was reflected in the resulting report. ${ }^{107}$ The early reports have been deemed as 'narrowly legalistic' and somewhat unsympathetic towards the claims. ${ }^{108}$

When Chief Judge Edward Durie (as he was then) was appointed Chair of the Tribunal, the Tribunal began to win back the confidence of Māori. It sat on marae and followed the protocol (or kawa) of the area during those hearings. Under the guidance of Durie, the Tribunal began to consider claims and the principles of the Treaty in a wider context and over time a new understanding of the Treaty began to emerge. The natural environment was considered in the context of kaitiakitanga; issues of land-loss were examined in relation to sovereignty and the resulting reports began to reflect this change in approach. ${ }^{109}$ The report on the Motunui-Waitara claim found that Te Atiawa of Taranaki were entitled to have its fishing rights protected under the Treaty and the proposed discharge of sewerage and industrial waste in the area would cause damage to those fishing grounds (and to Te Atiawa as tangata whenua), in a manner that was inconsistent with the principles of the Treaty. The Tribunal emphasised Māori cultural values and a Māori world view. This new interpretation of the Treaty and of Māori rights was not accepted outright. Prime Minister Robert Muldoon threatened to have the Tribunal disbanded. This

Station; Wai 3 Claim on Proposed Discharge of Sewage at Welcome Bay; Wai 4 Claim on Kaituna River, Wai 6 Claim on the Motunui-Waitara outfall

${ }_{106}$ Orange, The Treaty of Waitangi, 231.; see also Hamer, "A Quarter-Century of the Waitangi Tribunal: Responding to the Challenge," 4.; Walker, Ka Whawhai Tonu Matou: Struggle without End 245.

${ }^{107}$ Waitangi Tribunal, Report of the Waitangi Tribunal on a Claim by J.P Hawke and Others of Ngati Whatua Concerning the Fisheries Regulations, Wai 1 (Waitangi Tribunal, 1978).

${ }^{108}$ Hamer, "A Quarter-Century of the Waitangi Tribunal: Responding to the Challenge," 4.; Orange, The Treaty of Waitangi, 231.

${ }^{109}$ See for example Waitangi Tribunal, Report of the Waitangi Tribunal on the Motunui-Waitara Claim, Wai 6 (Wellington, 1983).; Report of the Waitangi Tribunal on the Manukau Claim, Wai 8.; Report of the Waitangi Tribunal on the Kaituna River Claim, Wai 4 (Wellington, 1984). 
was the era of 'think big' policies and the Motunui-Waitara claim struck at the heart of plans for Taranaki as a petro-chemical centre. ${ }^{110}$

Even though it was not able to investigate claims that had occurred prior to 1975 , in some cases the Tribunal went as far as commenting on historical aspects of contemporary claims. Although not anticipated by the 1975 Act, the Tribunal demonstrated that historical Crown actions continued to have consequences into the present. In the Manukau Report, for example, the Tribunal noted that it considered details of raupatu 'because consequences have followed that still have their effects today. ${ }^{111}$ Through this approach the Tribunal began to reveal a past that continued to have a profound_impact in the present.

The Tribunal considered the Treaty in a new and public way. In this early period the Waitangi Tribunal provided a contemporary interpretation of the Treaty in late twentieth century New Zealand, and in doing so began to breathe new life into it. In its Manukau Report the Tribunal referred to this new interpretation:

Given that the Treaty has not previously been part of the domestic law, we are to consider what steps might be taken to ensure that domestic laws and policies adequately reflect its general principles or what might be done to remedy or compensate for existing breaches....It follows that while we are to consider the "practical application of the Treaty" we must approach that task by seeking to give to the Treaty the fullest effect practicable. In this sense it is now no longer to be treated as 'a simple nullity' ${ }^{112}$

Placing the Treaty in contemporary New Zealand the Tribunal claimed: 'A Māori approach to the Treaty would imply that its wairua or spirit is something more than a literal construction of the actual words used can provide. The spirit of the Treaty transcends the sum total of its component written words and puts literal or narrow interpretations out of place. ${ }^{113}$ Claudia Orange suggests that in these early reports the Tribunal was 'testing the extent of its mandate', and while its discussions of

\footnotetext{
${ }^{110}$ Paul Temm, The Waitangi Tribunal: The Conscience of a Nation (Auckland: Random Century, 1990), 37.

${ }^{111}$ Tribunal, Report of the Waitangi Tribunal on the Manukau Claim, Wai 8, vii. This approach of 'considering but not investigating' pre-1975 events was also used in Report of the Waitangi Tribunal on the Kaituna River Claim, Wai 4. and Report of the Waitangi Tribunal on the Te Reo Maori Claim, Wai 11 (Wellington, 1986).

${ }_{112}$ Report of the Waitangi Tribunal on the Manukau Claim, Wai 8, para 8.1.

${ }^{113}$ Report of the Waitangi Tribunal on the Motunui-Waitara Claim, Wai 6, 47.
} 
Treaty principles were challenging its recommendations tended to be moderate. ${ }^{114}$ The Tribunal came to articulate Māori-Crown relations in a way that individual iwi or hapū never could. This, in turn had a political influence. An ongoing interaction developed between the analysis and findings of the Waitangi Tribunal and the development of Crown policy; at times an uneasy tension resulted.

\section{'Two People in One Nation', 1984}

In July 1984 the National Prime Minister Robert Muldoon called an early election. The National government was by then in its third term and increasingly unpopular. In contrast, the Labour party presented itself as a younger, fresher alternative to a tired National government. Under the leadership of David Lange, Labour gained a significant victory. As part of its new approach, the party was preparing to reinstate the Treaty of Waitangi at a level of official recognition excluded for nearly a century. ${ }^{115}$ It is significant that it was the fourth Labour government that simultaneously did so much to advance Treaty issues (primarily through the amendment to the Waitangi Tribunal) yet also posed the biggest threat to the possible return of Crown assets to Māori in the future (through the establishment of State-owned Enterprises and the transfer of Crown assets to these arms-length bodies).

In February 1984, Labour party spokesperson for Justice, Geoffrey Palmer, had announced Labour's new policies on the Treaty of Waitangi. The three main components were that Waitangi Day would be acknowledged in a more relevant way; that the Waitangi Tribunal membership would be expanded, the provisions guiding the Tribunal itself would be able to hear claims back to the signing of the Treaty in 1840; and that the Treaty of Waitangi would be included in a planned Bill of Rights. Labour was responding to a growing sense of urgency on Treaty issues. Māori agitation for action on the Treaty was growing. For example, a hīkoi drawing

\footnotetext{
114 Orange, The Treaty of Waitangi, 233.

${ }^{115}$ From the 1877 case when the Treaty was declared to be '[A] simple nullity', Wi Parata vs. Bishop of Wellington (1877) 3 NZ Jur (NS) SC 72; David V Williams, "The Constitutional Status of the Treaty of Waitangi: An Historical Perspective," New Zealand Universities Law Review 14, no. 1 (1990): 14.
} 
attention to the role of the Treaty in contemporary New Zealand journeyed from Ngāruawahia and arrived at Waitangi for Waitangi Day 1984. ${ }^{116}$

The Labour government was also soon about to take the country in an economic direction that had not predicted by the electorate, adopting and implementing free market, neo-liberal policies. ${ }^{117}$ 'The fourth Labour Government initiated the most sweeping reorganization of the machinery of government ever undertaken in New Zealand.' 118 The Treasury rose in power and influence during this period. This was a period of unprecedented bureaucratic and policy change, undertaken in great haste. The process of change was controversial, and Labour supporters were taken by surprise not just at the speed of change but also (and primarily) the direction, which had not been signalled to the electorate. The massive deregulation and destabilisation which followed particularly affected the Māori workforce.

The Government's goals for devolution of service delivery and the divestment of state involvement in Māori welfare, however, presented renewed opportunities for Māori to be more involved with Māori development initiatives, which tied in closely with the aims of self-determination, and for a time signalled the revival of recognition of Māori collectives. These aims were also consistent with government policy aimed at raising outcomes for Māori, while decentralising the role of the state. A new policy direction was signalled through the Hui Taumata or Maori Economic Development Conference in October 1984; through which the concept of a decade of Māori development was adopted. Among the themes for this decade was an emphasis on the Treaty of Waitangi, focusing on Māori-Crown relationships, the settlement of claims, and biculturalism. The initiative adopted became known as 'positive Māori development' and sought better outcomes for Māori while operating in a mainstream framework. Mason Durie points out that despite a difference in emphasis, positive Māori development and Māori self-determination have obvious similarities, for example emphasising social, cultural, and economic development, and Māori

\footnotetext{
${ }_{117}^{116}$ Ranginui Walker, "Locked in a Drama of the Past," New Zealand Listener, 17 March 1984, 58,60.

117 Malcolm McKinnon, Treasury: The New Zealand Treasury 1840-2000 (Auckland: Auckland University Press, 2003), 325.

118 Jonathon Boston, "Reorganizing the Machinery of Government: Objectives and Outcomes," in Reshaping the State: New Zealand's Bureaucratic Revolution, ed. J. Boston, Martin, J., Pallot, J., Walsh, P. (Auckland: Oxford University Press, 1991), 233.
} 
delivery systems. ${ }^{119}$ However, for a number of reasons the decade of Māori development did not reach its full potential. The incompatibility of Māori selfdetermination and the neo-liberal policies was one reason for this. ${ }^{120}$

\section{'A Catalyst for Action': The 1985 Treaty of Waitangi Amendment Act}

As part of its 1984 pre-election strategy, the Labour Party, under pressure from its longstanding Māori support base and its many Pākehā members supportive of giving greater recognition to the Treaty in contemporary New Zealand, had committed to amend the Treaty of Waitangi Act and extend the size and the scope of the Waitangi Tribunal. They undertook to grant the Tribunal retrospective powers to enable it to investigate claims back to 6 February 1840, the date the Treaty was signed. On 5 November 1984 the Labour Cabinet approved the drafting of the Treaty of Waitangi Amendment Bill to ensure its introduction before the end of the year and enable it to be enacted by the end of March 1985. Koro Wetere, Minister of Māori Affairs, introduced the Bill to the House just five months after Labour had returned to power. It was challenged by the opposition, who argued that awarding retrospective powers to the Tribunal would bring 'monumental' changes to private, public and individual lives and that the very system of land ownership was under attack. National MP Douglas Graham predicted that the flood gates on claims would be opened; he was concerned about the social and economic impacts of the Bill:

I am sure that all New Zealanders want to be as fair as possible in coming to grips with this complex problem: but the answer is not to go back to 1840 and review every Government act or omission, including settlements already reached and payments made, and try to decide 150 years later whether prejudice was involved. ${ }^{121}$

In response Geoffrey Palmer, Deputy Prime Minister and Minister of Justice, argued that ignoring the grievances will not make them go away. 'If we are to maintain

\footnotetext{
${ }^{119}$ Durie, Te Māna, Te Kāwanatanga: The Politics of Māori Self-Determination, 6.

${ }^{120}$ The election of a National government in 1990 has been cited as another reason for this. Durie, $T e$ Māna, Te Kāwanatanga, 9. Jane Kelsey, A Question of Honour? Labour and the Treaty 1984-1989 (Wellington: Allen and Unwin, 1990), 35.

${ }^{121}$ Douglas Graham, NZPD, vol.460, 2704.
} 
peace, good order, and good government in New Zealand it is essential to provide for the redress of grievances. ${ }^{122}$

The number of claims registered with the Waitangi Tribunal rose quickly, prompting commentators to question whether the government anticipated the sheer volume of historical claims. Some consider that Palmer was being naive, or at the least, narrowly legalistic in his expectations of what the impact of extending the Waitangi Tribunal's powers might lead to. ${ }^{123}$ Palmer responded that during his time in the United States in the late 1960s and early 1970s he witnessed generations of disenfranchised African Americans and did not want that situation to be repeated in New Zealand. ${ }^{124}$ The government needed to act to prevent such disenfranchisement.

Of particular interest, for the purposes of this thesis, is whether consideration was given at the time as to how a claim might be progressed following a Waitangi Tribunal inquiry and report. During the course of the Bill's passage through the House, questions were raised relating to how these grievances would be addressed, given that the Tribunal's powers would still be recommendatory. ${ }^{125}$ Geoffrey Palmer claimed that the previous Minister of Māori Affairs, Ben Couch, had failed to 'redress the grievances', a situation the Bill was intended to address. According to Palmer the 'purpose of this Bill is to provide an authoritative mechanism for the settlement of outstanding grievances.' He described the Waitangi Tribunal as a 'unique dispute settlement mechanism...devised in New Zealand, by New Zealanders to deal with the tangata whenua in a way that is suitable to them. ${ }^{126}$ Winston Peters, (Opposition spokesperson on Māori issues) pointed out that the Bill had no criterion on compensation and did not indicate how settlements would be arrived at. ${ }^{127}$ In response, Peter Tapsell Minister of Internal Affairs, who represented the Eastern

\footnotetext{
122 Geoffrey Palmer, NZPD vol.460, 2708.

123 Alan Ward, Personal Communication, 29 August 2013.

124 Geoffrey Palmer, New Zealand's Constitution in Crisis: Reforming Our Political System (Dunedin: John Mclndoe, 1992), 75.

${ }^{125}$ Simon Upton, 18 December 1985, NZPD, vol 460, 2709.

126 Geoffrey Palmer, 18 December 1985, NZPD, vol.460, 2708.

${ }^{127}$ Winston Peters, 18 December 1985, NZPD, vol 460, 2703.
} 
Māori electorate, argued that matters of compensation would not be addressed by the Tribunal, but rather by the Courts. ${ }^{128}$

By the final reading of the Bill the matter of how Tribunal recommendations were to be considered or implemented was still not clearly resolved. Tapsell reported that the Tribunal would have 'recommendatory powers only. It does not have any power whatsoever to award compensation. The matter was considered at the Committee stage and the Government chose to avoid it'. ${ }^{129}$ So the Treaty of Waitangi Amendment Bill was passed into law without a clear direction of how recommendations from the Waitangi Tribunal would be considered, or a clear process for how past grievances would be resolved. The Labour government was later criticised for introducing legislation for which it had not fully considered the consequences. The debate in the House would suggest that its strategy to equip the Waitangi Tribunal with the capacity to be able to investigate back to 1840 was seen as the resolution to outstanding grievances, rather than a step in that process. This is evidenced by the fact that no strategy was put in place to consider what might happen to claims beyond the Tribunal inquiry process. Nor were any resources set aside for the resolution of grievances following an investigation by Waitangi Tribunal. Palmer later wrote that 'It would be for the government of the day to do something about the recommendations.' This course of action was not evident from the Parliamentary Debates at the time. ${ }^{130}$ Once again, government moved to address Māori grievances, but only to a limited extent.

The general purpose of the Bill was to extend the scope of the Tribunal to investigate claims dating back to the signing of the Treaty of Waitangi, 6 February 1840. Given that a greater number of claims were anticipated, the Waitangi Tribunal was also to be extended to six appointees (of whom at least four had to be Māori), plus the Chief Judge of the Māori Land Court. The Tribunal could also appoint research and administrative staff, and appoint counsel to assist it and to assist claimants. Not surprisingly, the number of claims registered with the Tribunal began a steady increase from this time. The Tribunal could not keep up with the demand.

\footnotetext{
128 Peter Tapsell, 18 December 1985, vol. 460, NZPD, 2706.

129 Peter Tapsell, 3 December 1985, vol. 468, NZPD, 8630.

130 Palmer, New Zealand's Constitution in Crisis: Reforming Our Political System, 80.
} 
To an extent this was unavoidable. The research and inquiry process is intrinsically detailed, complex, and therefore tends to be lengthy. Then again, the widespread surfacing of historical claims had not been predicted by Labour in opposition. At the insistence of the affected iwi, the government found itself having to address claims it considered long settled, such as Taranaki, Waikato and Ngāi Tahu. Research soon revealed that these grievances had not been fully addressed in the earlier period, and the agreements struck at that time had not been upheld. ${ }^{131}$

The additional staff allocated for the Tribunal, under the Treaty of Waitangi Amendment Act proved insufficient to keep up with the number of historical claims. This resulted in longer waiting times between the registration of claims and the research and inquiry process. In June 1987, 88 claims had been registered and the Tribunal had reported on 13. By the middle of 1991, there were 216 registered claims of which 27 had been inquired into and reported on. ${ }^{132}$ This increase in business for the Tribunal led to the appointment of more Tribunal members, increasing the numbers to 16 in 1988, which allowed for the Tribunal to hear more than one claim at a time. Yet the Tribunal was still not really able to make up ground as the number of claims registered continued to rise, by the early 1990s the gap between number of claims registered and number of claims reported on was even greater as the number of new claims increased significantly. This increase continued with more than 75 claims being registered with the Tribunal each year since $1990 .{ }^{133}$ Matters of funding of the Tribunal and the speed with which the Tribunal was able to research and inquire into claims became a recurring political issue over the years. These came to the fore again as the process of direct negotiation began to gain traction.

\footnotetext{
${ }^{131}$ Richard S. Hill, "Enthroning "Justice above Might"?: The Sim Commission, Tainui and the Crown," (Treaty of Waitangi Policy Unit, Department of Justice, Wellington, 1989).

${ }_{132}$ W. H. Oliver, Claims to the Waitangi Tribunal (Wellington: Waitangi Tribunal Division, Department of Justice, 1991), 12.

${ }^{133} 31$ August 1995, Draft 'Report to Parliament - the Settlement of Claims under the Treaty of Waitangi', ST 02000002 Part 2, OTS archive
} 


\section{The Treaty in a Policy Context}

At a policy level, the Labour Government continued to demonstrate its commitment to the Treaty of Waitangi. In June 1986 Geoffrey Palmer, then Deputy Prime Minister and Minister of Justice and Koro Wetere, the Minister of Māori Affairs, proposed that government departments should be directed to give recognition to the Treaty of Waitangi 'as if it were part of the domestic law of New Zealand in all aspects of administration and in the preparation of legislation'; to regard the Treaty as 'always speaking' and to apply it in a way that gives effect to 'its true intent and spirit'; and 'to consult with the Maori people on all matters affecting the application of the Treaty. ${ }^{134}$ An officials subcommittee reported to Cabinet Policy Committee on the implications for Palmer and Wetere's proposal. The eight page report gives an insight into concerns of officials at the time; uncertainty was expressed around the 'modern realities' of interpreting the Treaty, for example how much force should be put on the "full, exclusive and undisturbed" possession as promised in Article two. Officials suggested that this interpretation allowed for the possibility that Māori land may be excluded from compulsory acquisition, such as under the Public Works Act. Another concern raised was that 'the full application of the "undisturbed" principle' might mean that the Crown would not be able to obtain a water right or a fishery right if the Māori owners objected. ${ }^{135}$ There was uncertainty as to the 'interrelationship between the first and second articles' of the Treaty. Various government departments sought clarification and guidance on interpreting the 'true intent and spirit of the Treaty'. ${ }^{136}$ It was noted that as the Treaty was to be considered 'living and organic' and was not defined by the Treaty of Waitangi Act 1975 or the draft Bill of Rights, government departments were looking to the recent findings of the Waitangi Tribunal as a source of interpretation of the Treaty principles.

The Officials Committee also considered the proposal of Palmer and Wetere that all future legislation should take the Treaty of Waitangi into account and advised that

\footnotetext{
13413 June 1986, 'Treaty of Waitangi: Implications of Recognition', Officials Committee Report to the Cabinet Policy Committee; see also Butterworth, Maori Affairs: A Department and the People Who Made It.

13513 June 1986, 'Treaty of Waitangi: Implications of Recognition', 'Officials Committee report to the Cabinet Policy Committee, 1

${ }_{136} 13$ June 1986, 'Treaty of Waitangi: Implications of Recognition', 'Officials Committee report to the Cabinet Policy Committee, 2.
} 
the best time for this would be when policy approval was sought from Cabinet. It suggested that reference to 'Treaty of Waitangi' should be included in all Cabinet papers, and the 'Department of Māori Affairs could advise if they were in any doubt as to whether a Treaty issue might be involved. ${ }^{137}$ The Committee also noted that there was potential for different interpretations of Treaty principles to emerge if each government department was individually responsible for applying them. It therefore recommended that some form of central monitoring be introduced to eliminate the possibility of inconsistently applying Treaty principles. It was recommended that 'all future legislation referred to Cabinet at the policy approval stage contain a mandatory reference to any implications for recognition of the principles of the Treaty of Waitangi' and that government departments should consult with 'the appropriate Māori people on all significant matters affecting the application of the Treaty.' Finally, the Committee noted that the financial and resource implications of these changes could be considerable and should be assessed in the future. ${ }^{138}$

The matter came before Cabinet ten days later, where it was agreed that 'all future legislation referred to Cabinet at the policy approval stage should draw attention to any implications of the principles of the Treaty of Waitangi' and that departments 'should consult with appropriate Maori people on all significant matters affecting the application of the Treaty'. ${ }^{139}$ These recommendations were a significant variation to 'business as usual' for government departments, yet it is not clear to what extent this was appreciated at the time. Although these moves were radical ones, Claudia Orange has observed; 'the government and its agencies were only partly aware of the likely impact on their work. ${ }^{140}$ They are an example of an expedient policy, introduced to address a particular problem, but which had ongoing implications that were not fully considered at its introduction. This thesis demonstrates that there were a number of such policy decisions in the decade under investigation. A salient

\footnotetext{
13713 June 1986, 'Treaty of Waitangi: Implications of Recognition', 'Officials Committee report to the Cabinet Policy Committee, 5-6.

13813 June 1986, 'Treaty of Waitangi: Implications of Recognition', 'Officials Committee report to the Cabinet Policy Committee, 8.

13923 June 1986, 'Treaty of Waitangi: Implications of Recognition', CM 86/22/7

140 Orange, The Treaty of Waitangi, 236. The Treasury recognised that this would have major implications for all of government. See for example Chapter 5 'The Implications of the Treaty of Waitangi', in The Treasury, "Government Management: Brief to the Incoming Government 1987, Vol.1," (Wellington: The Treasury, 1987).
} 
example of underestimating the impact of the Cabinet decision came a few months later when the State-owned Enterprises Bill was introduced to the House late in 1986.

\section{The State-owned Enterprises Act}

While Māori were increasingly having Treaty of Waitangi rights acknowledged through the Waitangi Tribunal and through the Labour government's policy commitment to the Treaty of Waitangi, the government was pressing on with market-driven economic policies. ${ }^{141}$ It was the latter that resulted in one of the most significant court cases on Treaty matters principles ever considered by a New Zealand Court. The object of the State-owned Enterprises (SoE) Bill, introduced to Parliament in September 1986 was to transfer Crown owned assets, previously managed by government departments, to a group of new state-owned commercial enterprises on 1 April 1987. The assets were to be managed as private entities, with profits being returned to the Crown. These were market-driven economics in action; and included the proposed transfer of extensive land holdings to the newly formed Land Corporation. Māori were concerned that the transfer of Crown land to one of nine new corporations could easily lead to full privatisation over time (which they suspected was the government's intention). There was growing disquiet among Māori that Crown land which was subject to Treaty of Waitangi claims, (which might have been available to be returned as part of the settlement of those claims), could potentially be alienated prior to such a resolution. It was somewhat ironic that just when the Tribunal had been extended to consider breaches back to 1840 large amounts of Crown assets (up to 10 million hectares) were to be removed from direct Crown ownership. ${ }^{142}$

During its hearing into the Muriwhenua fisheries in December 1986, the Tribunal released an interim report warning the government that any compensation sought by claimants was likely to be prejudiced by the Bill, and that such prejudice would be

\footnotetext{
${ }^{141}$ By this time the Waitangi Tribunal had issued seven reports

142 Hayward, "Flowing from the Treaty's Words: The Principles of the Treaty of Waitangi " 31.
} 
contrary to the principles of the Treaty. ${ }^{143}$ It recommended that Crown assets within the Muriwhenua rohe not be transferred to any State-owned Corporation while the Muriwhenua fisheries inquiry was ongoing. In response to general Māori unrest, the Crown amended the Bill to include a new section on the Treaty of Waitangi; 'nothing in this Act shall permit the Crown to act in a manner that is inconsistent with the principles of the Treaty of Waitangi'. Section 27 was also amended to give protection to land for which claims had been registered prior to 18 December 1986, the date of the assenting of the Act. This still left claims made after this date in an uncertain position, as they may have been 'on-sold to a third party' and therefore not be available to be returned as part of a settlement. ${ }^{144}$

Māori were not assured that this new section offered sufficient protection to the Crown assets. The New Zealand Māori Council, under Sir Graham Latimer brought proceedings to the High Court in Wellington on 30 March 1987, asking for an order preventing the transfer of Crown assets to State-Owned Enterprises, and for the case to be moved to the Court of Appeal. The Court of Appeal returned its judgment on 29 June 1987. Each of the five Court of Appeal judges (Cooke, Richardson, Somers, Casey, and Bisson) reported separately but unanimously found in favour of the Māori Council and required the government to negotiate with it to develop a system that would satisfy the interests of Māori and government. The case marked a turning point in New Zealand legal history. ${ }^{145}$ In his judgement, the President of the Court of Appeal, Sir Robin Cooke noted that many matters considered by the Court had already been extensively considered in earlier findings by the Waitangi Tribunal. ${ }^{146}$ Perhaps just as importantly in terms of lasting impact, were the Court of Appeal's findings relating to the principles of the Treaty of Waitangi and the ongoing relationship between the Treaty partners, Māori and the Crown. The Court stated:

The Treaty signified a partnership between Pakeha and Maori requiring each to act towards the other reasonably and with the utmost good faith. The relationship between the Treaty partners creates responsibilities analogous to

\footnotetext{
${ }^{143}$ Waitangi Tribunal, Interim Report to Minster of Māori Affairs on State-owned Enterprises Bill, 8 December 1986 reproduced as Appendix A3.4.1 in Waitangi Tribunal, Report of the Waitangi Tribunal on the Muriwhenua Fishing Claim (Wai 22) (Waitangi Tribunal, 1988), 290.

${ }^{144}$ Orange, The Treaty of Waitangi, 237.

${ }^{145}$ R P Boast, "New Zealand Maori Council V Attorney-General: The Case of the Century?," New Zealand Law Journal August (1987): 240.

${ }_{146}$ New Zealand Maori Council v Attorney-General [1987] 1 NZLR.
} 
fiduciary duties. The duty of the Crown is not merely passive but extends to active protection of Maori people in their use of their lands and waters to the fullest extent practicable..$^{147}$

These words have gained enormous significance in official and public discourse. ${ }^{148}$

The Court of Appeal finding was a setback for the government's plans and had clearly not been anticipated. Geoffrey Palmer, later noted that the Government's decision to incorporate that section in the State-Owned Enterprises Act 'was not taken lightly, nor was it taken without some awareness that it could have some significant consequences. ${ }^{149}$ Negotiations between the New Zealand Māori Council and the government ensued and resulted in a redrafted The Treaty of Waitangi (State Enterprises) Act 1988. This Act provided for the transfer of Crown assets to State-owned Enterprises, but offered as a safeguard the provision that any land that was on-sold would include a memorial on its title. Such a memorial would enable the Waitangi Tribunal to order a legally binding recommendation to return land to Māori ownership if an inquiry revealed that any land had been acquired in breach of the Treaty. This new power conferred on the Waitangi Tribunal caused some unease in the political arena. ${ }^{150}$ The government had planned to privatise Crown commercial forests in 1988, the same way it had proposed with SoE land, that is, with little or no consultation with Māori. However, given the Court of Appeal's decision in 1987, the government was obliged to deal with the forested lands in accordance with the principles of the Treaty. Rather than sell the land, government agreed to retain the land (so as not to jeopardise any future Treaty claims) and sell just the cutting rights to the forest. Money from the rentals from licensing 'would be

\footnotetext{
${ }^{147}$ New Zealand Maori Council v Attorney-General [1987], 1 NZLR 642.

${ }^{148}$ A great deal has been written on the significance of the Lands Case and its ongoing impact on Treaty jurisprudence. See for example Ruru, 'In Good Faith' Symposium Proceedings Marking the 20th Anniversary of the Lands Case.

${ }^{149}$ Geoffrey Palmer, Treaty of Waitangi (State-Owned Enterprises) Bill debate, 8 December 1987 NZPD, vol 485, 1715.

150 This unease continues in some quarters. Despite this, the Tribunal has proved cautious with its power of compulsory return of land. Rather than use this power of resumption, the Tribunal has tended to reference its authority but encourage negotiations between claimants and the Crown. These have become known as 27B Memorials; which denotes the relevant clause of the Act. Hill, Maori and the State: Crown-Maori Relations in New Zealand/Aotearoa, 1950-2000, 223-6.; Durie, Te Māna, Te Kāwanatanga: The Politics of Māori Self-Determination, 182-4.
} 
held and managed by the Crown Forestry Rental Trust (CFRT), pending research of Māori claims on forested land.'151

Waikato Māori were concerned that the Government intended to privatise the government owned Coal Corporation (Coalcorp). In 1989 the Tainui Māori Trust Board filed papers with the High Court to protect its interests in coal on raupatu (confiscated) land and registered two claims with the Waitangi Tribunal. ${ }^{152}$ The board sought reassurance that the memorialised protection offered by the Stateowned Enterprises Act would also apply to mining licenses. The Court found in favour of Waikato-Tainui. In his decision, the President of the Court of Appeal, Sir Robin Cooke, pointed out that ' $[T]$ he principles of the Treaty required that the Treaty partners, the Crown and Waikato-Tainui, make a genuine effort to work out an agreement. $^{1153}$

Many Māori were encouraged by the findings of the judiciary over these cases. There was a sense that the Treaty of Waitangi was finally gaining the legal recognition it deserved. Also at this time, with Chief Judge Edward Durie as Chairman, a consistently bicultural dimension to New Zealand colonial history began to emerge through the published reports of the Tribunal. The reports presented a bicultural reading of the Treaty, with an emphasis on the principles of the Treaty in contemporary New Zealand. ${ }^{154}$ Alan Ward points to concern from the public that the Waitangi Tribunal process was uncovering problems that were better left in the past. ${ }^{155}$ In reality what was being exposed were grievances that had never gone away, but were only now getting an opportunity to be considered.

\section{8: The Establishment of the Treaty of Waitangi Policy Unit}

The year 1988 marked a conscious attempt by government to take firmer control over Treaty matters through the policy process. As has already been discussed, the

\footnotetext{
${ }^{151}$ Ward, An Unsettled History: Treaty Claims in New Zealand Today, 39.

152 Tainui Trust Board v Attorney-General [1989] 2 NZLR 513.; McCan, Whatiwhatihoe: The Waikato Raupatu Claim, 260.

${ }_{153}$ McCan, Whatiwhatihoe, 280.

${ }^{154}$ Andrew Sharp refers to this as the 'jurisprudence of the wairua' of the Treaty, Sharp, Justice and the Māori: Māori Claims in New Zealand Political Argument in the 1980s 163-77.

${ }^{155}$ Ward, An Unsettled History: Treaty Claims in New Zealand Today, 32.
} 
Treaty of Waitangi was coming to prominence through the court system and through the reports of Tribunal inquiries. Historical Crown actions were coming under scrutiny, and there was some pressure on government to respond to the growing number of recommendations emanating from the Waitangi Tribunal's inquiries. A policy vacuum was opening, and increasingly the government's position during the 1985 debate on the Treaty of Waitangi Amendment Act seemed inadequate. The Treasury briefing to the incoming government in 1987 demonstrated that the department had been considering the implications of findings of the Tribunal and the Courts, and considered that a broad policy response, rather than a case by case reaction was required. Treasury pointed to its own limitations in providing this analysis, 'in assessing the implications for the Treaty we are conscious that we have no specialist expertise in such areas as history, law and Māori culture.' It undertook the task regardless, pointing out that 'we do have a useful vantage point in assessing policies from our central position in the machinery of government. ${ }^{156}$ The Treasury briefing provides insight on the 'blank slate' that the government had on these issues at the time:

As a general principle it may be assumed that the greater the generosity of the Government, the greater the likelihood of claims being settled once and for all. On the other hand, the greater the generosity the greater the fiscal cost of the income forgone from the use of assets. It would be surprising if any settlement that might realistically be expected would extinguish all sense of grievance. ${ }^{157}$

By 1988, references to the Treaty of Waitangi and its principles had permeated every level of government, as two years earlier Cabinet had agreed that all legislation recommended to Cabinet level must include some reference to any implications of the principles of the Treaty of Waitangi. ${ }^{158}$ But a background paper by the Office of the Deputy Prime Minister, Geoffrey Palmer, to Members of Cabinet Policy Committee in June 1988 suggested that the government needed a more organized and coordinated approach to Treaty matters:

Until now the response to Treaty of Waitangi issues has been essentially an un-cordinated series of ad hoc responses. No general policies in respect to Treaty issues have been developed and no department has any overall

\footnotetext{
156 Treasury, "Government Management: Brief to the Incoming Government 1987, Vol.1," 320.

157 Treasury, "Government Management", 331.

15823 June 1986, 'Treaty of Waitangi: Implications for recognition', CM 86/22/7
} 
responsibility for co-ordinating the information and advice necessary to establish the Government's response to particular issues. There is a need for overall consistency of approach. ${ }^{159}$

There were also a growing number of specific issues awaiting some sort of resolution by government, and this number would grow as the Waitangi Tribunal continued with its inquiries. In particular, on several occasions undertakings had been made to commence some kind of negotiations with the Tainui Māori Trust Board and a recent Waitangi Tribunal report into the fishing claims of Muriwhenua had called for a response from the Crown. ${ }^{160}$

Palmer reflected that his own Department, that of Justice was a natural fit to provide policy advice to the Crown on Treaty issues; claiming that the Department of Māori Affairs were in the role of looking after the other Treaty Partner - Māori. ${ }^{161}$ As a result, the Treaty of Waitangi Policy Unit (TOWPU) was established by Cabinet Policy Committee at its meeting of 28 June 1988 and located within the Department of Justice. Its purpose was to provide advice to the Government on Treaty of Waitangi issues, to liaise with the Department of Māori Affairs over the implementation of recommendations from the Waitangi Tribunal, and to provide advice to other government departments on the obligations of the Crown to the Treaty of Waitangi. ${ }^{162}$ Legal academic Alex Frame was appointed as the inaugural Director of TOWPU. Over the next few months, Frame set about establishing the Unit, which began operation with a staff of six and a budget of $\$ 1$ million for the first year, thereafter $\$ 1.5$ million per annum.

At the same time, the Cabinet Policy Committee established a new Standing Committee of Cabinet, made up of the Minister of Māori Affairs, the AttorneyGeneral, the Minister of Finance and the Minister of State Owned Enterprises (with other ministers as required). The Committee's purpose was 'to facilitate direct

\footnotetext{
15927 June 1988, Background Paper by Office of Deputy Prime Minister to Members of Cabinet Policy Committee, TS 10 part 1 of 1 , OTS archive

${ }^{160}$ For details see Fisher, "Balancing Rangatiratanga and Kawanatanga: Waikato-Tainui and Ngāi Tahu's Treaty Settlement Negotiations with the Crown," 49-53. McCan, Whatiwhatihoe: The Waikato Raupatu Claim, 255-60.

${ }_{161}$ Palmer, New Zealand's Constitution in Crisis: Reforming Our Political System, 84.

16228 June 1988, Cabinet Policy Committee POL (88) M23/11, TS 10 1, OTS archive
} 
negotiations with Māori and implement the recommendations of the Waitangi Tribunal. ${ }^{163}$ Up to this point there had been no government-wide approach to the increasing references to the Treaty of Waitangi included in legislation, such as the Environment Act 1986, the Conservation Act 1987. Nor had there been any official response to the recommendations of the Waitangi Tribunal. It seems obvious that a process was required to consider those recommendations and respond to them.

\section{Chapter Conclusion}

This chapter has explored a watershed period of New Zealand history, as the Treaty of Waitangi rose to prominence to such an extent that central government had no choice but to actively take up its role as Treaty partner. The historical approach taken by the Crown to the Royal Commissions of the 1920s had not been in the context of the Treaty relationship, but rather was based on the notion of 'good conscience and equity'. As a reflection of the times, when announcing the Royal Commission to inquire into confiscated land and other grievances (the Sim Commission), Prime Minister and Native Minister, Gordon Coates, had considered that these matters should be regarded in the context of what was 'fair and just'. In other words, the enquiry did not come under the rubric of the Treaty of Waitangi. The inquiries of 1920s eventually led to several 'statutory agreements' in the 1940s, but these were very much on the Crown's terms. ${ }^{164}$ The Māori renaissance saw a revival of Treaty issues on a nationwide scale and the establishment of the Waitangi Tribunal was a signal that the Crown recognised that the Treaty had a role in contemporary New Zealand.

Within a relatively short period, the fourth Labour government had changed the future direction of the Treaty in New Zealand. In fact it was not long before the government's drive to push through new economic policies and its commitment to the Treaty of Waitangi collided. It was when the Tribunal was extended to inquire

\footnotetext{
${ }^{163}$ The standing committee was not named in this document, 28 June 1988, Minutes of Cabinet Policy Committee POL (88) M23/11, TS 101 , OTS archive

${ }_{164}$ Marr, "Crown Policy Towards Major Crown-Iwi Claim Agreements of the 1940s and 1950s: A Preliminary Report for the Treaty of Waitangi Policy Unit," 17.
} 
into claims from 1840 that the colonial past increasingly made itself felt in the present. On the one hand Labour had placed increased emphasis on honouring the Treaty, and on the other hand on free-market neoliberal policies which ran the risk of permanently alienating Crown land. While the Labour government may have been forced to put the Treaty of Waitangi back on the national agenda after a long absence there remained a tension between the phrase attributed to Hobson (at the time of the signing of the Treaty in 1840), 'we are all one people', and on the ground experience in Aotearoa/New Zealand. This was recognised by the Governor General, David Beattie in the Waitangi Day speech when he referred to 'two peoples in one nation'. While Waitangi Day commemorations in 1985 were less volatile than previous years, in part due to the initiatives of the decade of Māori development, Pākehā New Zealand was beginning to get an understanding of the complexities of our founding document, which were being brought into mainstream political discussion. Several major court cases meant that the government was compelled to engage with the Treaty at a policy level. Through 1988 and 1989 the Labour government sought to accommodate Māori rights as they had been asserted through protest action and the findings of the Courts, but its response was a moderating one; attempting to balance the findings of the Courts with tensions within Cabinet, government, and the wider New Zealand public. As a result, many Māori felt no closer to the goal of their rangatiratanga yet there was, on an unprecedented level, progress in addressing and recognizing historical grievances. 


\section{CHAPTER TWO: 'ESTABLISHING A PATTERN FOR THE FUTURE': 1989-1990}

In his speech at Te Awamarahi marae, Port Waikato on 24 November 1989 Prime Minister Geoffrey Palmer told those present that the Labour government was committed to the resolution of differences that had arisen from different interpretations and implementation of the Treaty. Palmer claimed that the fourth Labour government had done more than any other government to honour the obligations of the Treaty and that:

To find a resolution we must look forward, not backwards. We are establishing a pattern for the future - a basis on which to go forward. ${ }^{165}$

The Labour government had little option, but to engage with the Treaty, and historical breaches of it on a policy level. The previous decades of Māori renaissance of political agitation, protest, and action through the courts had led to the demand that central government heed this call and take up its role as Treaty partner. Through 1988 and 1989 the Labour government sought to accommodate the rights Māori were asserting through protest action and Court proceedings. Its approach was one of moderation, trying to balance tensions within Cabinet, the government, and the wider New Zealand public, yet to address and recognize historical grievances at a coordinate, detailed policy level. A Canadian-influenced model was introduced to establish a formal Negotiations Register to recognise claims that could be negotiated directly between claimants and the Crown.

Issues of land, fisheries, and Treaty principles all came together in this period. At the beginning of 1989 the Labour government needed to address the recommendations of the Courts and the Tribunal on several fronts. ${ }^{166}$ This was also an intense period of restructuring and reform; the fourth Labour government engaged in public sector reform, which impacted on all levels of government. Māori had been buoyed by the response of the Courts to these issues, although this success had been a long time in the making. For over a century Māori had been

\footnotetext{
16524 November 1989, PM Geoffrey Palmer, Speech at Te Awamarahi Marae, TE131, OTS archive

166 See for example McCan, Whatiwhatihoe: The Waikato Raupatu Claim, 246-54.
} 
accessing the judicial system to seek confirmation of the rights and obligations afforded them by the Treaty. The Māori Council or Lands case was significant as it 'implied that the Treaty had a constitutional status that should not ordinarily be negated by legislation. ${ }^{167}$ Likewise, findings of the Courts relating to restructuring of the forestry and fisheries sectors brought Article Two issues to the fore. Within a short period, the government was seeking ways to accommodate and moderate the findings of the judiciary and to contain the issues with policy and legislation rather than leaving it to the Courts to decide on the direction of the Treaty in contemporary New Zealand. ${ }^{168}$

This chapter demonstrates that through the period 1989 to 1990 the Labour government was obliged to acknowledge and engage with historical Treaty claims. Treaty issues were moving quickly and it was not long before it was considered that the Treaty of Waitangi Policy Unit had been 'inadequately resourced for the large and highly complex task assigned to it.' The unit had been required in 1989 to undertake additional work not originally envisaged in its terms of reference, including negotiating directly with Māori on behalf of the Crown on the Tainui 'scoping' discussions; the Waitomo claim, and the Māori fisheries agreement. ${ }^{169}$ The government acknowledged the existence of legitimate outstanding grievances, although the extent of grievances does not seem to have been appreciated at the highest levels. While Māori and some historians may have been familiar with the breadth of historical injustices there had not been any formal consideration of the degree of Treaty breaches as a result of colonisation, although TOWPU officials sought to advise ministers on these details and propose a way to approach historical claims.

There was (and remains) a tension, for the Crown between wanting to satisfactorily settle grievances for Māori, and be deemed fair to all New Zealanders. Public opinion was divided on how far the government should go compensating for

\footnotetext{
${ }^{167}$ Hill, Maori and the State: Crown-Maori Relations in New Zealand/Aotearoa, 1950-2000, 224.

168 Durie, Te Māna, Te Kāwanatanga: The Politics of Māori Self-Determination, 188.; Jane Kelsey, Rolling Back the State: Privatisation of Power in New Zealand/Aotearoa (Wellington: Bridget Williams Books Ltd, 1993), 213-6.

1694 December 1989, PM Geoffrey Palmer, Memo for Cabinet: 'Coordination of the Government's policy, legislation and negotiating position on Treaty of Waitangi Issues' attached to CAB(89) M $42 / 13,2$.
} 
historical claims and making accommodation in the law for the Treaty. ${ }^{170}$ Yet, it was increasingly obvious to the Labour government that it needed urgently to address the recommendations of the Waitangi Tribunal and findings of the courts, and implement a process of negotiating some resolution to claims. ${ }^{171}$ The Canadian approach to the process of addressing historical grievances was an example of what could be achieved here in New Zealand. New Zealand officials began to look closely at the Canadian experience. A relationship was established with Ian Cowie, a New Zealander working as a consultant in the field of Canadian aboriginal affairs. Cowie became an advisor to TOWPU and assisted with the establishment of the formal direct negotiations framework, details of which were published in 1990. ${ }^{172}$ As a result, the Crown Task Force on Treaty issues was established to manage the process of direct negotiations between government and Māori.

Meanwhile the fourth Labour government was increasingly fractured. In August 1989 David Lange resigned, and was replaced by the deputy leader, Geoffrey Palmer. At that time Bill Jeffries was appointed Minister of Justice, which included responsibility for Treaty policy and negotiations. On 4 September 1990, just weeks out from the general election, Mike Moore replaced Palmer as Prime Minister. By then Labour's departure from its traditional roots on socio-economic matters had taken its toll and in October 1990, the year marking 150 years since the signing of the Treaty of Waitangi, Labour was significantly defeated by National. The National Party had campaigned on removing all references to the principles of the Treaty from legislation and yet also acknowledged historical misunderstandings relating to the Treaty and sought to resolve 'genuine' grievances quickly. ${ }^{173}$ While there was a political desire to get historical Treaty claims dealt with and 'settled' as quickly as possible, they were nonetheless a priority for both major parties in the lead-up to the 1990 election.

\footnotetext{
170 Jack Vowles \& Peter Aimer, Voters' Vengeance: The 1990 Election in New Zealand and the Fate of the Fourth Labour Government (Auckland: Auckland University Press, 1993), 173.

${ }^{171}$ See for example 27 November 1989, Prime Minister Memorandum for Cabinet, 'Coordination of the Government's Policy, Legislation and Negotiating Position on Treaty of Waitangi Issues', TS 01 pt 1 of 2, OTS archive. Also at this time the Waitangi Tribunal was nearing the end of its substantial inquiry into the claims of Ngāi Tahu.

172 Issues, The Direct Negotiation of Maori Claims: An Information Booklet.

${ }^{173}$ NZ National Party, National Party Policies for the 1990s: Creating a Decent Society (Wellington: NZ National Party 1990), 18.
} 


\section{The Treaty Reassessed: Court Decisions and Policy Development}

The extension of the Waitangi Tribunal's jurisdiction to consider historical claims proved to be a defining moment for the legislative consideration of the Treaty. As McHugh observed, conduct of the Crown in relation to the Treaty would now be subject to audit by the Tribunal, according to the principles of the Treaty of Waitangi. The Crown had 'not only signified its willingness to submit itself to such external audit but also announced the voluntary adjustment of its internal practices to conform with Treaty principles. ${ }^{174}$ Throughout 1989 Treaty issues continued to rise to the centre of politics. There were several significant court cases relating to Treaty rights, including fisheries, forestry and coal, and broadcasting, which prompted a policy response.

In February 1989 Alex Frame, TOWPU's founding director, set out what he considered the future direction for the Unit. He had already appointed three specialist staff and an administrator, although it took some months for those appointees to take up their positions. ${ }^{175}$ Frame sought permission from the Minister of Justice to establish a temporary officials group to provide some overview to Treaty policy matters and to develop a strategic response to emerging issues and Treatybased legal proceedings against the Crown in areas such as fisheries, forestry, broadcasting and coal. The group of officials (which became known as the 'Treaty of Waitangi Officials co-ordinating group') would also provide instruction to the Crown Law Office, and more broadly the officials would consider how the 'relations between the Crown and its Māori Treaty partner may be turned towards more constructive and cooperative directions which may be of mutual benefit'. ${ }^{176}$

\footnotetext{
${ }^{174}$ McHugh, "From Soverignty Talk to Settlement Time: The Consitutional Setting of Māori Claims in the 1990s," 457.;see also Geoffrey Palmer, "The Treaty of Waitangi - Principles for Crown Action," Victoria University of Wellington Law Review 19 (1989): 335.

${ }^{175} 23$ February 1989, Briefing to Minister of Justice from Group manager, Policy Analysis and Development, Department of Justice, TS 03, OTS archive. TOWPU Director, Frame recalls the details of securing those early staff members, Alex Frame, "Raupatu Settlement - Legal Finality and Political Reality," in Raupatu: The Confiscation of Maori Land, ed. Richard Boast and Richard S. Hill (Wellington: Victoria University Press, 2009), 243.

17623 February 1989, Briefing to Minister of Justice from Group manager, Policy Analysis and Development, Department of Justice, TS 03, OTS archive
} 
Within the same briefing paper, Alex Frame proposed that TOWPU develop a set of principles to guide the Crown on issues relating to issues arising under the Treaty of Waitangi, to establish a policy base for the Crown on Treaty issues. These principles were to be derived from existing material from the Courts, the Waitangi Tribunal and the Treaty itself, and could then be relied on as the base-line from which the Crown could respond on Treaty issues, rather than the existing ad hoc reaction. At the end of March 1989 a copy of draft principles upon which the Crown proposed to act in relation to the Treaty, were sent to the Minister of Justice. ${ }^{177}$

Meanwhile a crisis over fishery rights was emerging. Three years earlier, in 1986 the government had introduced a quota management system to regulate the seafish industry, in an attempt to protect depleting fish stocks. Māori were concerned that the new system did not fully consider all of their interests in fisheries. Claudia Orange refers to some of the complexity surrounding Māori fishery rights:

Under article two of the Treaty, Māori are 'confirmed and guaranteed' the 'full, exclusive and undisturbed possession [rangatiratanga] of their lands and estates, forests, fisheries and other properties [taonga]'. However, fishery rights are also involved in the Crown's exercise in sovereignty, as well as the rights of all citizens at common law to fish. ${ }^{178}$

The New Zealand Māori Council, the Muriwhenua iwi of the far North, Ngāi Tahu and others, lodged applications for injunctions with the High Court. ${ }^{179}$ The applications were granted by the Court, and a joint working party of Crown officials and Māori leaders was set up to negotiate a settlement. ${ }^{180}$ But the two parties had very different expectations of what would constitute a reasonable settlement. ${ }^{181}$ The Tribunal issued the Muriwhenua Fishing Report in June 1988 which also fed into the negotiations process. ${ }^{182}$ Agreement on an interim Fisheries settlement was

\footnotetext{
177 Briefing by TOWPU Director, Alex Frame to Minister of Justice, 31 March 1989, TS0, OTS archive 178 Orange, The Treaty of Waitangi, 239.

179 Durie, Te Māna, Te Kāwanatanga: The Politics of Māori Self-Determination, 154.

${ }^{180}$ Ward, An Unsettled History: Treaty Claims in New Zealand Today, 46.

${ }^{181}$ For two different perspectives see Margaret Mutu, "'The Sea I Never Gave': Fisheries Settlements," in Treaty of Waitangi Settlements, ed. Nicola R. Wheen and Janine Hayward (Wellington: Bridget Williams Books, 2012), 114-23. and Palmer, New Zealand's Constitution in Crisis: Reforming Our Political System, 93-96.

182 Tribunal, Report of the Waitangi Tribunal on the Muriwhenua Fishing Claim (Wai 22). The Waitangi Tribunal had intended a comprehensive inquiry into all of the claims of Muriwhenua but
} 
eventually reached, the details of which were included in the Māori Fisheries Act 1989. The Act established a Māori Fisheries Commission, which was to receive 10 percent of the quota over a four year period. In addition $\$ 10$ million was provided to help establish Aotearoa Fisheries, a commercial fisheries company owned by the Māori Fisheries Commission. The final agreement, known as the 'Sealord deal' was negotiated in 1992; it marked a full and final settlement of all Māori commercial fishing claims under the Treaty of Waitangi. ${ }^{183}$ The experience of the Fisheries negotiations and the negotiated outcomes to some extent set a precedent for the land negotiations that were to follow. A number of Crown officials, ministers and Māori negotiators were prominent in both sets of negotiations.

This was a period of intense movement and activity within government departments. In July 1988, as part of the ongoing neo-liberal economic policies, the government had announced its intention to privatise its exotic forests. This was a further example of how Labour's ongoing commitment to a free market neoliberal economic strategy resulted in bringing Treaty issues to the political forefront. ${ }^{184}$ The government's original intention to corporatise 700000 hectares of forest in 1986 had already been restricted by the Court action against the State-owned Enterprises Act. As discussed above, the Court of Appeal decision on the SoE Act (the Lands Case) meant that the Crown was obliged to consider the transfer of Crown forests in accordance with the principles of the Treaty of Waitangi. Rather than do this, the government chose to sell the forests directly to the private sector, thereby circumventing any obligations of principles of the Treaty, under the SoE Act. In response, the New Zealand Māori Council sought an injunction on the sale of any Crown forests, as there was concern that much of the forestry land was subject to Treaty claims. After court-ordered negotiations, an agreement was reached between the Crown, New Zealand Māori Council and the Federation of Māori Authorities; by which 'the government decided to retain the land, sell only the cutting

given the timing of the introduction of the quota management system the Tribunal chose to issue an interim report on just the fishing claim at this time.

${ }^{183}$ The fisheries negotiations were complex and took some time to resolve. For further detail see Paul Moon, The Sealord Deal (Palmerston North: Campus Press, 1999), 155-71; Durie, Te Māna, Te Kāwanatanga: The Politics of Māori Self-Determination.

${ }^{184}$ Boston, "Reorganizing the Machinery of Government: Objectives and Outcomes." 
rights to the forest, and lease (or rather license) the land on which the forest grew'. ${ }^{185}$ Section 34 of the 1989 Crown Forest Assets Act established a trust, known as the Crown Forestry Rental Trust (CFRT). The role of CFRT was to manage the rentals from the licences and use the interest accumulated from investment of the fees to assist research and negotiations for Māori claimants with an interest in those forestry lands. Since 1990 CFRT has become a major funder of research for Treaty claims. Alan Ward pointed out that in its first decade the amount of funding CFRT was able to spend on research was 'greater than that made available to the Waitangi Tribunal itself. ${ }^{186}$

\section{Waikato-Tainui 'Scoping Negotiations'}

In June 1988, the government informed Waikato-Tainui that Coalcorp would be sold as part of the strategy for economic recovery. While the government made an undertaking to begin negotiations with the Tainui Māori Trust Board it continued with the process of selling Coalcorp, not seeing any conflict with the Treaty of Waitangi (SoE) Act, as it considered that the legislation was restricted to land alone. Tainui did not agree; still waiting for the Crown to begin negotiations, it filed papers with the High Court in an attempt to get the coal safeguarded under the Treaty of Waitangi (State Enterprises) Act 1988. Tainui argued that like land, 'mineral wealth such as coal should equally be set aside by the Crown and used in a future settlement'. ${ }^{187}$

Scoping negotiations between Waikato-Tainui and the Crown took place in the Waikato in July and August 1989 under the background of Court of Appeal proceedings on Coalcorp. ${ }^{188}$ Waikato-Tainui had been waiting to engage in negotiations with the Crown, as recommended by the Tribunal in the Manukau Claims Report and undertakings from the Crown with regard to State owned Enterprises. ${ }^{189}$ Waikato-Tainui had always been very clear on its own history, and did not feel the need to go through the process of a Tribunal inquiry. It also knew

\footnotetext{
${ }^{185}$ Ward, An Unsettled History: Treaty Claims in New Zealand Today, 39.

186 Ibid.

${ }^{187}$ Fisher, "Balancing Rangatiratanga and Kawanatanga: Waikato-Tainui and Ngāi Tahu's Treaty Settlement Negotiations with the Crown," 20.

188 Hill, Maori and the State: Crown-Maori Relations in New Zealand/Aotearoa, 1950-2000, 253.

${ }^{189}$ Tribunal, Report of the Waitangi Tribunal on the Manukau Claim, Wai 8.
} 
that the Crown were aware of its history too. TOWPU Director, Alex Frame, other TOWPU officials and a representative each from Treasury and Crown Law Office travelled to Tapuwae (the Māori Queen's rural marae) in the Waikato for these initial discussions. This was an opportunity for Crown representatives to hear directly about the impact of historical claims, with a particular emphasis on the spiritual aspects of the land and river to Waikato-Tainui who clearly stated that they sought the return of all Crown land holdings within the Tainui rohe. An outcome of these discussions was a document which set out the main arguments each side might raise in negotiations and to which the Government might agree. ${ }^{190}$ In addition, the Crown agreed that it would review the previous statutory agreements and the compensation arrangements to understand the reasons why these had not fulfilled the expectation of a 'full and final' settlement. Frame pointed out that this review would set a precedent for other historical claims settled by this type of statutory arrangements; Ngāi Tahu and Taranaki were specifically mentioned.

In October 1989 the Court of Appeal found unanimously in favour of the Tainui Māori Trust Board. The Court supported the argument that coal constituted an interest in land, therefore putting a halt to the proposed transfer of Crown ownership of coal to the State-owned Enterprise, Coal Corporation. Justice Robin Cooke encouraged Waikato-Tainui and the Crown, as Treaty partners to find resolution by negotiating directly with each other. The Court also stated that:

The Crown should take no action...in selling, disposing of or otherwise alienating the said lands until such time as the Crown has established a scheme of protection in respect of the rights of the plaintiffs [Tainui]. ${ }^{191}$

The government reserved its position as to whether to appeal the decision, although pressure was on it to engage with the findings of the Court. The Prime Minister Geoffrey Palmer did not appreciate that the Court of Appeal appeared to be overturning government policy; and later described the decision as 'an exercise in judicial activism'. ${ }^{192}$ The government took this as an opportunity to restate its authority on the Treaty relationship, as Palmer recalled:

\footnotetext{
${ }^{190} 5$ February 1990, Report from Director TOWPU to Core group of Officials, Crown Task Force on Treaty of Waitangi Issues, TS 01, OTS archive

191 Tainui Maori Trust Board v Attorney-General [1989] 2 NZLR 513 (CA) 527

192 , Geoffrey Palmer, 'Treaty of Waitangi Issues demand clarity, certainty', 2 January 1990, New Zealand Herald
} 
We had lost important cases and it seemed to the ministers they were being told they were about to lose the ability to govern on these issues...cabinet ministers meant they should make the final decisions not the courts. ${ }^{193}$

Waikato's chief negotiator Robert Mahuta later reflected that the Court of Appeal decision marked a 'turning point in the relationship between the tribe and the Government'. ${ }^{194}$ According to Mahuta, prior to the decision the Crown had been prioritising economic recovery over any rights Tainui might have had to the land it was privatising. The findings of the Court of Appeal provided the movement and momentum Tainui had been seeking for the Crown to engage with them directly, building on the scoping negotiations that had already taken place.

\section{Principles for Crown Action}

As the number of claims registered with the Tribunal increased, and as Māori demonstrated a willingness to appeal to the Courts for clarity, the Crown began to develop policy to address historical claims, rather than simply reacting on an ad hoc basis. Addressing and settling claims through some kind of direct negotiation process, rather than resorting to the Courts or waiting years for Tribunal decisions was the Crown preference. During this period the Crown started to think more strategically about the issues; the term 'a co-ordinated approach' is used frequently in the files. It was increasingly evident that the Crown needed to develop policy to address historical grievances. But there was no precedent, no template, and certainly no budget for settlements at this stage. The Treaty of Waitangi Policy Unit was the primary agency of government with Treaty issues at the core of its mandate; meanwhile other government departments were beginning to develop specialist Treaty divisions. Cabinet itself was divided on how these issues should be considered and it was the momentum of key ministerial figures, such as Geoffrey Palmer and his successor Bill Jeffries, supported by TOWPU, that drove strategic policy thinking at the time.

\footnotetext{
${ }^{193}$ Palmer, New Zealand's Constitution in Crisis: Reforming Our Political System, 92.

194 Robert Te Kotahi Mahuta, "Tainui: A Case Study of Direct Negotiation," in Treaty Settlements: The Unfinished Business, ed. Geoff McLay (Palmerston North: Victoria University of Wellington Law Review and the New Zealand Institute of Advanced Legal Studies Inc., 1995), 78.
} 
The Treaty of Waitangi Policy Unit quickly began to provide strategic policy advice, it was the only section of the public sector that had the expertise to attend to this work at short notice. In July 1989 it published the Principles for Crown Action on the Treaty of Waitangi. This document was the first public policy emerging from the newly established TOWPU and was presented as a summary of the Crown's approach to the principles of the Treaty. The Tribunal had pointed out that Treaty principles were more than the text of the Treaty itself; stating that the Treaty 'did not create rights, at domestic law, but laid down the principles from which defined rights might flow. The essential task is not to apply the Treaty's literal words but to locate the correct principle. ${ }^{195}$ The Principles for Crown Action presented the Crown's approach to the Treaty principles in a policy context - what were the principles that were influencing the Crown as it considered its role as Treaty partner when interacting with Māori and Treaty claims? The principles had been worked on over several months by officials in the Treaty of Waitangi Officials Co-ordinating Group, led by TOWPU, and were approved by Cabinet on 22 May.

The Principles for Crown Action was published in two formats. A small, 'summary version' was printed intended for interested members of the public, while a detailed A4 size version was intended to provide more detailed information, particularly for the public sector. This version included background information on the origins and meanings of each of the principles, although at 15 pages the so-called detailed version is still relatively brief. Geoffrey Palmer, as Deputy Prime Minister, Minister of Justice and Attorney-General, explained that the principles gave the government 'a place to stand' in relation to the Treaty and the debates and controversies surrounding it. He argued that this explanation was needed to 'dispel doubt and remove confusion' among the public and, even more importantly, to 'give Government Departments and agencies a clean set of policy guidelines about how to approach Treaty issues. ${ }^{196}$

The first principle was the 'Principle of Government' or the 'Kawanatanga Principle'. It related directly to the first Article of the Treaty, and gave 'expression to the right of the Crown to make laws and its obligation to govern in accordance with

\footnotetext{
195 Tribunal, Report of the Waitangi Tribunal on the Muriwhenua Fishing Claim (Wai 22), 213.

${ }^{196}$ Palmer, "The Treaty of Waitangi - Principles for Crown Action," 338.
} 
constitutional process'. Significantly, this right or 'sovereignty is qualified by the promise to accord Māori interests specified in the second Article an appropriate priority.' The commentary sought to pre-empt possible disquiet about 'the exercise of sovereignty [being] subject to a promise to protect a specified Māori interest'; it pointed out that this was not a new interpretation and that New Zealand's legislative sovereignty is subject to many other binding undertakings entered into by treaty in areas of trade, human rights, transportation. ${ }^{197}$

Principle Two, was known as the Rangatiratanga or Self Management Principle. It was guided by the second article of the Treaty, which the publication noted guaranteed to iwi Māori the control and enjoyment of those resources and taonga which it was their wish to retain. The preservation of a resource base, restoration of iwi self management, and the active protection of taonga, both material and cultural, were said to be necessary elements of the Crown's policy of recognizing rangatiratanga. The second principle was qualified by the first principle. Just as kawanatanga was 'subject to a promise to protect Rangatiratanga', then rangatiratanga was subject to an acknowledgement of kawanatanga. According to the document, the balance between these two Treaty Articles would need to be considered on a case by case basis, and was part of an ongoing dialogue and consideration. ${ }^{198}$ The accompanying commentary noted that 'the second Article is a powerful statement of the price paid by the Crown for what it obtained in the first Article.' The Court of Appeal ruling was drawn on to illustrate this: 'the duty of the Crown is not merely passive but extends to active protection of Māori people in the use of their lands and waters to the fullest extent practicable.' According to Frame the first and second Articles of the Treaty are 'both strong statements and each qualifies the other'. 199 The third principle was described as the Principle of Equality, and related to the third Article of the Treaty, which accorded Māori all the 'rights and privileges of British subjects'. The principle noted that Article three of the Treaty constituted a guarantee of legal equality between Māori and other citizens of New Zealand, meaning all New Zealanders are equal under law.

\footnotetext{
197 Justice, "Principles for Crown Action on the Treaty of Waitangi," 9.

198 Justice, "Principles for Crown Action on the Treaty of Waitangi", 10.

${ }_{199}$ Alex Frame, "A State Servant Looks at the Treaty," New Zealand Universities Law Review 14, no. 1 (1990): 83.[emphasis in original]
} 
The fourth and fifth principles departed from alignment with the text of the Treaty and reflected some social, legal and political developments in the wake of the Māori renaissance. The fourth principle was termed 'the Principle of Cooperation' and was influenced by the concept of 'partnership' as articulated by the findings of the Court of Appeal and the Waitangi Tribunal. For example, the 1987 Lands Case had emphasized the Treaty signatories as 'partners' who needed to act toward each other 'with the utmost good faith'. Co-operation as articulated in this principle, related to 'shared understandings and common objectives', which would take place if consultation was undertaken on major issues of concern and if both sides displayed 'good faith, balance, and common sense'. ${ }^{200}$

The fifth principle was entitled the Principle of Redress. This principle provided the first clear indication of the Crown's commitment to addressing and settling historical Treaty claims in a systematic process. It stated that the 'Crown accepts a responsibility to provide a process for the resolution of grievances arising from the Treaty.' This in itself was a powerful statement from the Crown. The text pointed out that any redress should 'take account of its practical impact and of the need to avoid the creation of fresh injustice. If the Crown demonstrates commitment to this process of redress then it will expect reconciliation to result'. ${ }^{201}$ This was the first time that a government document had set out a clear intention of providing redress for settlements as a general policy, and was therefore a breakthrough in the acknowledgement of Māori land and other historical grievances. This principle also mentioned that the process of redress could involve the Waitangi Tribunal, courts, or direct negotiation - thereby implicitly consenting to establish a process of direct negotiation with the government. Prompted by Crown discussions with WaikatoTainui, this principle added a new dimension to the process: the possibility of direct negotiation with the Crown, bypassing the Waitangi Tribunal. ${ }^{202}$ Indeed, as this thesis demonstrates, over time direct negotiations between claimants and the Crown have become an established way of resolving historical Treaty claims.

\footnotetext{
200 Justice, "Principles for Crown Action on the Treaty of Waitangi," 14.

201 Justice, "Principles for Crown Action on the Treaty of Waitangi," 15

202 Although Waikato-Tainui still reserved their right to return to the Waitangi Tribunal
} 
The Principles for Crown Action of the Treaty of Waitangi were a policy breakthough. As noted by Richard Hill, the principles:

confirmed explicitly for the first time the need for the compensation for historical grievances, incorporated judicial and Tribunal pronouncements, stressed the need for good-faith cooperation between Crown and Māori and recognized the need to work towards Crown-Māori partnership. ${ }^{203}$

They were favourably received in some quarters for providing contemporary guidance on the Crown's approach to the Treaty, but there was also opposition. Some Māori academics and church leaders viewed the Principles as an attempt to re-establish government control over the Treaty of Waitangi following the recent judicial and Tribunal findings. Mason Durie for example, was critical that the Crown was returning 'Treaty issues to the political arena, rather than relying on the Tribunal or a court of law'. ${ }^{204}$ Professor Hirini Mead, at the time Head of Māori Studies at Victoria University of Wellington, referred to the Principles as biased and as limiting 'the interpretation of rangatiratanga.' ${ }^{205}$ In response, Geoffrey Palmer (who had become Prime Minister within a few weeks of the publication of the document), stated that the final application of the Treaty had always been with the Crown, rather than the Courts. He repeated this sentiment in November and December 1989 when he directly addressed the question of whether the Crown would appeal the Court of Appeal's finding in favour of Tainui in the Coalcorp case. ${ }^{206}$

While in opposition, the National party had been highly critical of the Principles for Crown Action, but after being elected in 1990, it did not reject them outright. Rather, the Cabinet requested that Treaty of Waitangi Policy Unit officials review the principles. However when Minister of Justice, Douglas Graham took on responsibility for Treaty issues in May 1991 the matter was not pursued any further. ${ }^{207}$ So although the National government did not openly promote the Principles as the previous Labour government had done, they were not abandoned either. The Principles were subsequently explicitly endorsed and elaborated upon

\footnotetext{
203 Hill, Maori and the State: Crown-Maori Relations in New Zealand/Aotearoa, 1950-2000, 237.

204 Durie, Te Māna, Te Kāwanatanga: The Politics of Māori Self-Determination, 188.

2054 July 1989, 'Treaty guide clearly biased, says Prof Mead', The Evening Post,

20624 November 1989, PM Geoffrey Palmer, Speech at Te Awamarahi Marae Waikato, TE131, OTS archive; 15 December 1989, 'Palmer Puts Courts in Place', The Evening Post

207 Interview with former Crown official 1, 3 November 2014
} 
by several government departments and have continued to be part of the general public sector guidelines.

\section{The Crown Asserts its Position on the Treaty}

On 24 November 1989 Geoffrey Palmer addressed the Maori Queen, Te Arikinui Dame Te Atairangikahu, Robert Mahuta and other Tainui and Kingitanga leaders, at Dame Te Atairangikahu's home marae, Te Awamarahi, Port Waikato. ${ }^{208}$ The speech was significant, as the Prime Minister had travelled to Waikato to announce that the government had decided not to appeal the Court of Appeal's decision on Coalcorp. $\mathrm{He}$ asserted that the government was not prepared to let the courts have the final say on how the Treaty would be interpreted; rather these issues were political in nature and 'must be settled through the political organs of government. Broad issues relating to use of resources in our system of government cannot be decided by the Courts.' Palmer reiterated that the 'Courts interpret the law. They do not legislate. They do not govern. The Executive governs. ${ }^{209}$ Palmer reiterated Labour's dedication to Treaty issues; 'We are committed, as a government, to the comprehensive resolution of the differences which have arisen. ${ }^{210}$ He stated a commitment to engage in negotiations with Tainui to see why the 1946 settlement had not met its 'full and final' objectives. Palmer pointed out that the Principles for Crown Action may provide some way to remedy the situation.

At a post-Cabinet press conference on 27 November Palmer confirmed that the government were not going to appeal the Court of Appeal decision to the Privy Council. He also admitted that Crown Law had advised the Crown was unlikely to win an appeal. He stated that government were reviewing the Treaty resolution process to date and were working on developing a structure for dealing with claims. There was some concern that issues around the Treaty had become unclear:

the people have become confused because there are so many different branches of government involved in this. The Courts are involved in it; Parliament are involved in it and also the executive arm of Government is

\footnotetext{
${ }^{208}$ Palmer had replaced David Lange as Prime Minister on 8 August 1989.

20924 November 1989, PM Geoffrey Palmer Speech Te Awamarahi marae, TE 13 2, OTS archive 210 ibid
} 
involved in it. What I want to make absolutely clear to people is that the Government will make all of the final decisions. The Government on this matter is going to govern. ${ }^{211}$

The files demonstrate that some of this strategic work had been going on for some months. In August Cabinet had discussed the importance of establishing a coordinated approach to handling Māori land claims. ${ }^{212}$ TOWPU had been instructed to prepare a paper setting out 'principles for the handling of Māori land claims by government departments, and clear procedures for a consistent and co-ordinated approach to decision-making on them. ${ }^{213}$ Bill Jeffries, as new Minister of Justice, noted that TOWPU had begun investigating options for this, in particular whether a negotiations register might be used to progress claims. Soon after Palmer's speech TOWPU engaged lan Cowie, as consultant on indigenous rights and claims resolution in Canada, to visit in December 1989 and provide some expertise on the Canadian experience on the resolution of historical land claims. ${ }^{214}$ The Canadian model, as presented by Cowie was accepted and altered to suit the New Zealand situation. ${ }^{215}$

The policy coordination on the Treaty of Waitangi issues paper (which Palmer had referred to at his 27 November press conference) came before Cabinet at the end of November, prior to the planned visit by Cowie. The previous attempts to coordinate policy at a ministerial and officials level had proved unsatisfactory. A standing committee of Cabinet which had been established in June 1988 (at the same time that TOWPU was established) to facilitate direct settlement of Māori grievances and to implement the recommendations of the Waitangi Tribunal had been disestablished in February 1989, as the structure had not been working effectively,

\footnotetext{
21127 November 1989, PM Geoffrey Palmer, post Cabinet press conference, TE13 2, OTS archive ${ }^{212}$ Cited in 21 November 1989, Memo from Office of Minister of Justice to Secretary of Cabinet Office, TS 01 Part 2 OTS archive 213. 21 November 1989 Memo Minister of Justice to Secretary of the Cabinet office, TS 01 Pt 2, OTS archive ${ }^{214}$ Cowie had hosted Alex Frame and Edward Durie in Canada in August 1989, TOW 111 1, OTS file ${ }^{215}$ Cowie's document 'Discussion Paper, 'Government Policy for Handling Maori Claims and Treaty related Issues', received by TOWPU in December 1989, TE 15(2) pt 5 of 6 OTS archive; According to the file he spent the week 11-15 December 1989 at the TOWPU Office working on this (no further details were available in the files I accessed), TS 11 pt 1, OTS file. There was a further example of correspondence relating to the drafting of The Direct Negotiation of Maori Claims: An Information Booklet, 13 June 1990, TE 18 pt1, OTS archive
} 
'due in part to Ministers' competing commitments. ${ }^{216}$ For some time after this, matters were referred to the more broadly focussed Cabinet Social Equity Committee. ${ }^{217}$ And a core group of officials had been temporarily appointed to examine the policy and strategic issues arising from the legal proceedings, report to the Cabinet Policy Committee and liaise with existing officials committees. ${ }^{218}$ But again this arrangement was not satisfactory, primarily because government policy was 'not sufficiently developed to handle the issues in a consistent and coherent way'. ${ }^{219}$ A Cabinet Paper of 30 November set out the Prime Minister's recommendations for a new approach to Māori claims. ${ }^{220}$ It was proposed to establish a new system for 'handling Māori claims and Treaty-related issues' by implementing a new ministerial Committee and an officials group to replace existing arrangements. This was to become known as the Crown Task Force on Treaty of Waitangi Issues. He also proposed increasing resources to TOWPU to better reflect the additional roles it had been assigned. ${ }^{221}$

Cabinet approved of the establishment of the Crown Task Force on Treaty of Waitangi Issues, as a new system for handling Māori claims and Treaty-related issues, early in December 1989. A new Cabinet Committee on Treaty of Waitangi Issues was created, chaired by Minister of Justice Bill Jeffries. Other members were David Caygill, Minister of Finance; Stan Rodger Minister of State-owned Enterprises; Koro Wetere, Minister of Maori Affairs; Roger Douglas, Minister of Special Projects, and David Lange as Attorney-General. The new Cabinet Committee was to develop 'a clear and consistent policy and legislative framework in respect of Māori interests in natural resources' and clear procedures for the handling of Māori claims.

To facilitate these claims a "negotiations register" was to be established to prioritise and handle claims. The Cabinet Committee was also going to take responsibility for implementing negotiated agreements, Waitangi Tribunal recommendations that were

\footnotetext{
${ }^{216} 4$ December 1989, PM Geoffrey Palmer briefing attached to CAB (89) M 42/13,2

${ }^{217}$ Reasons were provided for this structure not achieving its goals, 30 November 1989 PM Geoffrey Palmer Memo attached to CAB (89) 941, TS 01, OTS archive

${ }^{218}$ This group was chaired by TOWPU, other officials represented the Treasury, the Department of Maori Affairs and the Prime Minister's office.

2194 December 1989, PM Geoffrey Palmer briefing in CAB (89) M 42/13, 2

${ }^{220}$ Although it should be noted that such initiatives are generally instigated by (and certainly drafted by) officials themselves.

${ }^{221} 30$ November 1989, CAB (89) 941, TS 01, OTS archive
} 
accepted by government, and Court judgments. Finally, the Cabinet Committee was also to take on the role of monitoring public awareness and attitudes to Māori claims and identify 'appropriate material to remedy misinformation. ${ }^{\prime 222}$ This Committee was supported by a new core group of officials, which became known as the Officials Standing Committee on Treaty of Waitangi Issues. Officials representing the Department of Prime Minister and Cabinet, the Treaty of Waitangi Policy Unit, Treasury, Crown Law Office, and Ministry for Maori Affairs were to be permanent members, with officials from other departments involved as needed.

Palmer saw this structure as underlying a new phase in the government approach to Treaty claims. The new ministerial committee, the core group of officials, a strengthened Ministry of Maori Affairs and Treaty Policy Unit all signalled a substantial step forward in handling Māori claims. ${ }^{223}$ The functions of TOWPU were enhanced to better reflect this expanded role; the policy unit was now to coordinate the Crown's position and instruct the Crown Law Office before Waitangi Tribunal hearings - which was a growing task. TOWPU was also tasked with conducting direct negotiations with Māori on behalf of the Crown, as it had been doing since the scoping negotiations with Tainui. It was expected that 'the new system should be presented as a complement to the Waitangi Tribunal and a recognition of the importance of settling outstanding claims in a measured and predictable way.'

At the beginning of 1990 TOWPU Director, Alex Frame, set out the policy priorities for the Crown. Many of these were issues that had been highlighted during the visit from the consultant lan Cowie. In particular, Frame reported that a clear system for managing the negotiation process needed to be formulated, and financial assistance should be made available to claimants to participate in the negotiations process. He also proposed the establishment of a negotiations register, which would determine a clear and orderly queue for negotiations. A further initiative was the implementation of a negotiating process with three discrete phases: a Framework Agreement, Agreement-in-Principle, and Final Agreement. These approaches came directly

\footnotetext{
2224 December 1989, CAB (89) M 42/13

${ }^{223} 4$ December 1989, PM Geoffrey Palmer briefing in CAB (89) M 42/13, 6. At this time the Department of Maori Affairs had undergone a restructure, replaced by Ministry of Maori Affairs (from 1 July 1989) and the Iwi Transition Agency (to be in place until 1994). For further details see Butterworth, Maori Affairs: A Department and the People Who Made It, 120-1.
} 
from the Canadian model. ${ }^{224}$ The following month Frame presented the position on the Waikato-Tainui negotiations; the two parties had previously agreed to recommence negotiations in March. But the parties had very different starting points. In November, while at Te Awamarahi marae, Palmer had undertaken to investigate why the 1946 agreement had not met expectations, whereas Waikato-Tainui sought a fresh consideration of its historical claims and the return of as much Crown land within the raupatu area as possible. Frame predicted that any reconsideration given to Tainui's 'full and final' settlement of 1946 was likely to set a precedent for other major settlements, particularly for Ngāi Tahu and Taranaki. ${ }^{225}$

\section{A Reassessment of Historical Claims}

The Principles for Crown Action had set out, for the first time, a government's clear intention of providing redress or compensation for grievances as a general policy. But there was a wide difference in approach between the positions of the Crown and that of the Tainui Maori Trust Board. Given Waikato-Tainui's position it was accepted that a reassessment of the historical record may be necessary. In late 1989 Alex Frame reported to the Minister of Justice some reasons why it would be 'neither prudent nor honourable' to assert the 1940s settlement as a complete answer to any further claims. He suggested that the 1940 s settlements be mobilised as 'a powerful moderating' force on claimant demands, and should be used as a counter to any rigid positions adopted by claimants. ${ }^{226}$

Part of the issue was clearly trying to establish the basis on which redress was to be made. TOWPU had been asked to report back to Cabinet on the 'origins and nature of the 'full and final; settlements negotiated by Prime Minister Peter Fraser after World War II.' The resulting report claimed it would be 'neither prudent nor honourable' for the government to consider the 1940s settlement as a complete

\footnotetext{
22425 January 1990, TOWPU Director Briefing to Core Group of Officials, Crown Task Force on TOW Issues

${ }^{225} 5$ February 1990, TOWPU Director Briefing to Core Group of Officials, Crown Task Force on TOW Issues, TS 01 pt 2, OTS archive. The Waitangi Tribunal was due to issue its report on the Ngāi Tahu claims in the first half of 1990. Taranaki, like Waikato-Tainui had been subject to a 'full and final' agreement in the 1940s.

${ }^{226} 8$ November 1989 , Memo by Alex Frame, Director of TOWPU to Minister of Justice, W.P. Jeffries, 8 October 1989, T1/50, OTS archive
} 
answer to the claims, but it could be used as the basis on which to begin new negotiations. The suggested Crown position was that 'these settlements were intended to be full and final by both sides, but that the desired result has not been fully achieved'. It was recommended that the Crown negotiate with claimants to come to a solution consistent with the Principles for Crown Action on the Treaty of Waitangi released by Government in July 1989. ${ }^{227}$

Accompanying this briefing was a report compiled at the Prime Minister's request and within a very tight timeframe by TOWPU historian Richard Hill on the major Māori settlements of the 1940s. ${ }^{228}$ Although intended as a first-cut at investigating these issues this document has been relied on heavily over time. The report briefly canvassed the grievances relating to Ngāi Tahu, 'the Lakes' of Te Arawa and Tūwharetoa, raupatu amongst others and noted the limitations of those earlier agreements in two particular areas. The first of these related to monetary compensation: 'The various monetary compensations, particularly those paid out over a period of time or in perpetuity have not withstood the test of time.'229 The second concern of the report, considered more significant than the annual payments, was what the report described as 'the neglect of the 'spiritual dimension". This related particularly to the 'raupatu tribes', who experienced confiscation of their lands and alienation from their sites of significance. The payments had 'in no way addressed the loss of mana and of spiritual taonga. ${ }^{230}$ The report and accompanying briefing paper were a significant reconsideration of the approach of the 1940s. Officials explained that historical grievances needed to be considered more widely than simply compensation for loss of land, but extended to a broader connection with the land and therefore a more profound sense of loss caused by

\footnotetext{
227 Ibid

${ }^{228}$ Hill, "Settlements of Major Maori Claims in the 1940s: A Preliminary Historical Investigation. The Ngai Tahu Grievance and Its Ramifications."

${ }^{229}$ lbid. 11

${ }^{230}$ Ibid. 12
} 
land alienation. ${ }^{231}$ Officials stressed 'the need to take reconciliatory action' to address these ongoing grievances. ${ }^{232}$

Another facet of this work was the acknowledgement that the payments established under the statutory agreements had been inadequate, in part because they had not been inflation adjusted. The inflation rate experienced in the 1970s, and the 1980s, meant the payments did not hold their value. An independent statistician was contracted to prepare a report on the Crown payments made to the Tainui Māori Trust Board and other Trust Boards, and the result of the non-indexing to inflation of their settlements with the Crown in 1940s'. ${ }^{233}$ The report compared the payments actually received (in 1989 dollars) by the Te Arawa, Ngäi Tahu, Tainui, Taranaki, and Tuwharetoa Māori Trust Boards and the amount which would have been received had all payments been indexed to inflation. The lack of inflation-adjustment for the payments meant that the respective Trust Boards had missed out on significant income between the time they had been established and 1989. According to the calculations, the difference between indexed payments and the actual payments to the Tainui Maori Trust Board in the period between 1946 and 1989 (measured in 1989 dollars) \$ 6767309 . Figures were also provided for the other Trust Boards, which reflected a similar 'loss' due to the non-inflation adjusted approach. ${ }^{234}$

There was still a sense of the government trying to base any future arrangements with Waikato-Tainui on the 1946 agreement, thereby limiting the possible implications of a reassessment of all of the previous arrangements. The Minister of Justice writing to Robert Mahuta in March 1990 reflected this; 'one obvious respect in which the settlement has lagged behind is that inflation (which was negligible, or even negative, during the negotiations period) has almost certainly destroyed the value of the annuity.' He wrote that officials were reviewing the historical record,

\footnotetext{
${ }^{231}$ The Waitangi Tribunal had recognized this for some time. As noted in the previous chapter, the Sim Commission had not recommended returning any land of significance, concluding that too much time had passed since land had been confiscated in 1860s, AJHR 1928 G7

${ }^{232}$ Richard S Hill, "A Quarter Century of Treaty of Waitangi Reconciliation Processes, 1988-2013: An Appraisal," http://www.victoria.ac.nz/stout-centre/research-units/towru/publications/ReconciliationProcesses.pdf. 4

${ }^{233}$ TOWPU Historian to contract statistician, 21 December 1989, TI 50, OTS archive

23423 March 1990, 'Indexation of payments to Māori Trust Boards Report', TI 50, OTS archive.
} 
although added that he 'considered the 1946 agreement was a result of careful discussion in good faith by both parties and was fair by standards of the time. ${ }^{235}$ Whereas Waikato-Tainui did not regard the agreement with such integrity, it was of the opinion that agreement was the result of an ultimatum delivered to Te Puea by the government of the day. ${ }^{236}$

But TOWPU officials, who were engaging in historical research, had been advising for some months that merely readjusting the inflation rate on the 1946 agreement was not going to be sufficient; a "shift" in thinking was required. ${ }^{237}$ TOWPU Director, Alex Frame acknowledged that there may not have been sufficient acknowledgment of the full impact that alienation of land had on Waikato-Tainui. ${ }^{238}$ Officials were open to the proposition of the restoration of Crown land and reported back accordingly to ministers. Richard Hill has said that during the 1989 scoping negotiations with Waikato the elders spoke of being orphans on their own land following the 1865 confiscation. ${ }^{239}$

Throughout 1990 the Treaty of Waitangi Policy Unit and the Officials group on Treaty of Waitangi Issues worked on policies for direct negotiations, which were published in The Direct Negotiation of Maori Claims: An Information Booklet. ${ }^{240}$ This was the first public insight into the formulation of policies for the Crown to negotiate with Māori. Ian Cowie had contributed to the drafting of the publication. The booklet said that when a claim met certain criteria and was approved by the Crown Task Force it could by-pass the Tribunal inquiry process, and be accepted on the Negotiations Register for direct negotiations with the Crown. A significant aspect of this new process was ensuring that the claimant negotiators had clear authorisation, or mandate to act on behalf of a specific group of claimants, and a specific claim. It

\footnotetext{
${ }^{235} 21$ March 1990, Minister of Justice, W P Jeffries to Robert Mahuta, Tainui Maori Trust Board. $236 \mathrm{lbid}$. See also 8 March 1990, '\$1b Waikato land talks will be test for Waitangi Task Force', Auckland Star. The letter and the article quote Mahuta on this point ${ }^{237}$ See Hill, "Enthroning "Justice above Might"?: The Sim Commission, Tainui and the Crown." Cathy Marr, "Crown Policy Towards Major Crown/lwi Agreements in the 1940s and 1950s," (Wellington, 1990).

${ }^{238} 5$ February 1990, Memo by Alex Frame, Director TOWPU, setting out Position of Tainui settlement, as at early 1990, Core group of Officials, Crown Task Force on Treaty of Waitangi Issues, TS 01, OTS archive

${ }^{239}$ Hill, "A Quarter Century of Treaty of Waitangi Reconciliation Processes, 1988-2013: An Appraisal" 6. This aspect was later included in the Crown apology to Waikato-Tainui, Waikato Raupatu Claims Settlement Act, 1995, Sec 6

${ }^{240}$ Issues, The Direct Negotiation of Maori Claims: An Information Booklet.
} 
was a priority that those acting on behalf of the claimants correctly represented the claimant group associated with a particular claim, and that group correctly represented the geographical area under claim. ${ }^{241}$

The policy of claimant funding was also introduced at this time; funding was to be made available to claimants while they were in the process of negotiation. Both of these policies signalled a significant shift in thinking. The Principles for Crown Action were also reproduced in this booklet. It was also clearly recognised that claims inquired into by the Tribunal would eventually require negotiation between the affected party and the Crown.

The Negotiations Register was established in June 1990 and staff at the Treaty of Waitangi Policy Unit and the Waitangi Tribunal worked on assessing which claims registered with the Tribunal might be suitable for negotiation or mediation. By October 1990, at the time of the general election there were eight claims on the Negotiations Register, at different stages of the negotiation process. ${ }^{242}$ A total of 160 claims had been registered with the Waitangi Tribunal by this stage. In July 1990 Neil Martin succeeded Alex Frame as Director at the Treaty of Waitangi Policy Unit. Martin had previously worked on the negotiations of the interim Fisheries Settlement. The new Director reflected the increased TOWPU focus on the actual negotiations between claimant groups and the Crown

\section{0: The Treaty and the General Election}

The year 1990 marked 150 years since the signing of the Treaty of Waitangi. As preparations were made to commemorate this occasion, New Zealand was on the cusp of a new approach to dealing with historical land grievances, which also coincided with a new bicultural vision for the country. Political scientists Vowles and Aimer point out that there were divergent views of Māori operating within the country; 'evoked by the manifestations of low social status, high employment and

\footnotetext{
${ }^{241}$ Ibid., 8. Approval had been given by the Cabinet Committee on Treaty of Waitangi Issues in February 1990 TOW (90) M 2/2

242 Department of Justice, 'Post-election Briefing 1990', 122.
} 
high crime rates', contrasted with the open adoption of Māori symbols as part of a New Zealand identity, such as at the opening of the 1990 Commonwealth Games, the Te Māori exhibition, and the positive reaction to the appointment of Sir Paul Reeves as the first Māori Governor General. ${ }^{243}$ The occasion of the sesquicentennial also signalled the opportunity for reflection on New Zealand's 'progress as a nation'. This included some assessments from historians, and a host of new books emerged geared towards 1990 and reflections of nation-hood. ${ }^{244}$

Due in part to this commemorative year, the Treaty of Waitangi and issues of race relations gained an importance in the lead up to the general election of October 1990. Treaty issues had risen to prominence during Labour's second term in office; particularly precipitated by the inherent tensions between the pursuit of free-market policies and Treaty of Waitangi issues. While the Labour government had demonstrated a commitment to the Treaty of Waitangi, a potential 'backlash' was brewing: 'to many Pakeha electors, Maori demands in the name of the Treaty were confusing and irritating and sometimes even threatening. ${ }^{245}$ But more importantly for Labour's electoral fate was the extent to which it had moved from the mandate of the party membership and voting base. By 1990 the Labour government was paying the price for its swing from core Labour principles to neo-liberal policies, and it lost office on 27 October 1990.

The National party had indicated a cautious approach to Treaty issues. Speaking in October 1989, opposition leader, Jim Bolger was critical of the Labour government's 'carelessness over Treaty of Waitangi rights'. He claimed the government had 'opened a Pandora's box with the loose wording in its state-owned enterprises legislation on the principles of the Treaty of Waitangi and Māori interests in land'. ${ }^{246}$ In May 1990 Winston Peters, as National's Māori affairs spokesperson, said that a

\footnotetext{
${ }^{243}$ Aimer, Voters' Vengeance: The 1990 Election in New Zealand and the Fate of the Fourth Labour Government, 171.

${ }^{244}$ For commentary on this see Lorenzo Veracini, Negotiating a Bicultural Past: An Historical 'Revolution' in 1980s Aotearoa/New Zealand, vol. Number 7, Treaty of Waitangi Research Unit Occassional Papers Series (Wellington: Treaty of Waitangi Research Unit, Stout Research Centre, Victoria University of Wellington 2001).

${ }^{245}$ Aimer, Voters' Vengeance: The 1990 Election in New Zealand and the Fate of the Fourth Labour Government, 172.

${ }^{246} 11$ October 1989, Leader of the Opposition to New Zealand Manufacturers Federation Annual Conference, TE 131 , OTS archive
} 
'future National Government should eradicate recognition of the Treaty of Waitangi from all legislation'. ${ }^{247}$ This position was criticised in an editorial in The Evening Post:

It is easy to forget the angry pre-1984 land marches and protests and therefore underestimate Labour's success in defusing Māori anger and channelling grievances into legal forums. ${ }^{248}$

In the lead-up to the 1990 election National promoted itself as the party to put New Zealand back on the path to 'prosperity and security'. ${ }^{249}$ In relation to Māori Affairs, National undertook to acknowledge the Treaty of Waitangi as the founding document of New Zealand, resolve misunderstandings relating to the Treaty, and quickly resolve outstanding Māori grievances that are genuine and proven. ${ }^{250}$ The National party won the election by a landslide, and with Jim Bolger as Prime Minister formed the government. Immediately after the election Treaty issues went to Winston Peters as Minister of Māori Affairs, though, as TOWPU was a unit within the Department of Justice it continued to report to the Minister of Justice (now Douglas Graham). In effect there was no equivalent unit set up in Manatū Māori, so TOWPU continued to run negotiations

In the post-election update officials noted that significant progress had been made in the development of the claims negotiation process. However they also pointed out that 'Māori involvement will be required if the policy is to achieve working credibility' and that any negotiation policy involving both Crown and Māori should have 'the commitment of both parties if it is to generate settlements that will attract the required political support from both sides'. ${ }^{251}$ In December 1990 Prime Minister Jim Bolger stated National's commitment to the Treaty claims process, as well as to developing clear and consistent policy. The new National government was aware that becoming 'bogged down' by Treaty issues would not prove popular with its

\footnotetext{
2475 May 1990, 'Peters believes proposal to wipe out Treaty has caucus support', The Dominion

24810 May 1990, Editorial, Evening Post

${ }^{249}$ National Party, National Party Policies for the 1990s: Creating a Decent Society 1.

250 National Party, National Party Policies for the 1990s: Creating a Decent Society 18.

251 Department of Justice, 'Post-election Briefing 1990', 122.
} 
constituents. It sought to address negotiations promptly and to also closely monitor public attitudes to Māori claims. ${ }^{252}$

Despite its early rhetoric the National government struggled to find an overall policy approach to settle claims. At this time the Waitangi Tribunal was getting ready to report on Ngāi Tahu's claims, concluding the largest and most comprehensive hearings the Waitangi Tribunal had conducted. These reports were to pose a challenge to the government. Was it to accept the Tribunal's findings and recommendations? If the findings were that large amounts of compensation were owed to Ngāi Tahu what implications would this have for other claims?

\section{Chapter Conclusion}

The years 1989-1990 were pivotal for the formation of the basis of a process of direct negotiations between claimants and the Crown. The Labour government was challenged to respond to Court decisions and Tribunal reports. While the Labour government had facilitated the extension to the Waitangi Tribunal's powers and the establishment of Treaty of Waitangi Policy Unit, these moves in themselves did not directly facilitate or enable the resolution of historical grievances. In fact even as late as 1989 the government had been of the opinion that the historical statutory agreements in place with Ngāi Tahu, Taranaki, and Waikato were robust and did not need to be reconsidered. This position was challenged by Māori and by Crown officials, as they examined the foundation and the historical details of those earlier agreements. A process of direct negotiations between Crown and claimants was signalled by the ongoing negotiations between Waikato-Tainui and the policy work done to publish The Direct Negotiation of Maori Claims: An Information Booklet. ${ }^{253}$ These policies marked a significant shift in approach, and offered a pathway to resolving historical grievances.

The 1990 general election signalled that Treaty issues were a priority across the political spectrum. When the fourth National government came to power in

\footnotetext{
${ }^{252}$ February 1991, Memo for Cabinet on Treaty of Waitangi Issues, attached to CAB (91) M19/17, 13 14

${ }^{253}$ Issues, The Direct Negotiation of Maori Claims: An Information Booklet.
} 
November that year it took some time for it to gain an understanding of Treaty issues. 


\section{CHAPTER THREE: RAPID POLICY DEVELOPMENT}

\section{1-1993}

This chapter examines how National approached its pre-election undertakings in its first term of office. At the time of the general election of 27 October 1990, Treaty of Waitangi issues were significant, yet National remained somewhat conflicted about its position on these matters. Its Māori Affairs spokesman, Winston Peters had campaigned on removing references to the Treaty and its principles from legislation. National's stated policy was to treat all New Zealanders fairly and equally, which involved encouraging Māori to become fully active in the development of the country. National had also campaigned to establish a clear process for outstanding Māori grievances and to equitably settle all major grievances by the end of the century. ${ }^{254}$ It was keen to underplay the focus on historical grievances and concentrate rather on getting Māori fully engaged in the economy. However, by this time the Waitangi Tribunal had become an entrenched and valued entity. Moreover, there were now over 20 references to the Treaty in legislation which would have been difficult to remove. Significantly, Māori had an expectation that their Treaty partner was beginning to take responsibility for its role.

As outlined in the previous chapters, growing Māori and Pākehā agitation calling for the Treaty of Waitangi to be honoured and for past Crown breaches of the Treaty to be addressed grew throughout the 1980s. Initially this was done through the investigations of the Waitangi Tribunal. However, neither historical investigations nor the recommendations of the Waitangi Tribunal in and of themselves could resolve historical grievances, and over time the focus shifted further towards resolution. Attention moved from the Waitangi Tribunal and the inquiry of historical claims, to developing a process for addressing and settling individual claims. An increased focus on direct negotiation between claimants and the government without the need for a Waitangi Tribunal inquiry gave further political impetus to the

\footnotetext{
${ }^{254}$ New Zealand National Party, "Facing the Future Togther: National's Policy on Maori Affairs," news release, 22 July 1990, 1990.; Party, National Party Policies for the 1990s: Creating a Decent Society 18-19.
} 
process. From the 1990 general election on, political manifestos featured policies on the Treaty of Waitangi and the resolution of historical Treaty of Waitangi grievances. There was ongoing tension between the pressure resulting from protest, the outcome of judicial action and a shift to a post-colonial view, and the perception of the general population, who are predominately non-Māori. ${ }^{255}$ This tension was always in the minds of officials and politicians. Douglas Graham, as Minister of Treaty settlements from May 1991 was always particularly sensitive to the electorate's perception of Treaty settlements. ${ }^{256}$

At the beginning of its parliamentary term the National government was reticent about the extent to which it wanted to engage with Treaty matters. While in opposition, National leader Jim Bolger had been critical of what he saw as Labour's carelessness over Treaty rights and it was not clear how he would approach the issues. An indication that the new Prime Minister was somewhat ambivalent about Treaty settlements, at least initially, was the transfer of responsibility for Treaty settlements from the Minister of Justice to the Minister of Māori Affairs, Winston Peters. In opposition, Peters had been a vocal critic of Treaty principles in legislation and had warned he would limit the Waitangi Tribunal's mandatory recommendations under the State owned Enterprises Act. ${ }^{257}$ There was also clear tension between the National party hierarchy and Peters at this time. It is little wonder Māori and the community felt some uncertainty about how Treaty matters might progress as the fourth National government took office. The fact was that progress on Treaty issues had come too far to be neglected. The Treaty of Waitangi Policy Unit continued to provide policy advice to its minister, Douglas Graham, even while Peters was Chair of the Cabinet Committee on Treaty of Waitangi issues. For the most part TOWPU continued to fulfil the bureaucratic requirements related to Treaty issues, whereas Peters took charge of the political issues. On the ground very little had changed for TOWPU staff. ${ }^{258}$ A briefing from the Director of TOWPU to the Secretary for Justice in April 1991, noted that the Cabinet Committee on

\footnotetext{
${ }^{255}$ Around $10 \%$ of the population were Maori in 1990, New Zealand, https://www3.stats.govt.nz/New Zealand Official Yearbooks/1992/NZOYB 1992.html, accessed 4 April 2014 ${ }^{256}$ Interview with former Crown official 1, 3 November 2014 ${ }^{257}$ Hill, Maori and the State: Crown-Maori Relations in New Zealand/Aotearoa, 1950-2000, 247. ${ }^{258}$ Interview with former Crown official 1, 3 November 2014
} 
Treaty of Waitangi Issues had 'not yet made any decisions on policy, process or structural issues.'259 Part of the lack of progress has been attributed to Winston Peters, who was given initial responsibility for Treaty Settlements and was Chair of the Cabinet Committee on TOW issues, in his role of Minister of Māori Affairs. His Department, Manatū Māori were given responsibility for the lead role on developing policy and implement any negotiated agreements or Waitangi Tribunal hearings. These had previously been the role of TOWPU (as set out by Cabinet in December 1989). ${ }^{260}$ Peters was generally unsupportive of Treaty issues, having campaigned on abolishing references to the principles of the Treaty in legislation, repealing the Runanga Iwi Act and scaling back the role of the Waitangi Tribunal. While the Act was repealed in May 1991, little else seems to have been achieved on his preelection undertakings.

The roles of developing policy advice on Treaty issues and negotiating settlements were removed from Winston Peters and returned to the responsibility of the Minister of Justice, Douglas Graham, and therefore TOWPU in May 1991. By this time little progress had been made on National's pre-election Treaty pledges to make the negotiation and settlement of outstanding historical Treaty of Waitangi grievances a priority. This was about to change. Due to the growing expectations from Māori and the community, and with Graham and his officials resuming the lead on Treaty issues, the government soon gave higher priority to the settlement of historical claims. The release of the Tribunal's report on Ngāi Tahu's claims raised these expectations further. ${ }^{261}$ Another impetus to establish a clear process for addressing historical grievances came from Minister of Finance Ruth Richardson and the Treasury who were keen to push on with priorities for privatising Crown assets. It referred to Māori interests in those assets as a 'roadblock' to progress. At this point

\footnotetext{
25922 April 1991, Briefing from Director of TOWPU to Secretary for Justice, 'Future of Treaty of Waitangi Policy Unit' ; see also Ranginui Walker, "Te Karanga: Claim Jumping," Metro Magazine, March 1995.

2604 December 1989, 'Policy Coordination on Treaty of Waitangi Issues, CAB (89) M 42/13. Manatū Māori were also given provision to report, through its Minister, directly to the Cabinet Committee without going through the Officials Standing committee on TOW issues. See March 1991, Memorandum for Cabinet Committee on Treaty of Waitangi Issues: Report on current and suggested government approach and structures for resolution of Treaty of Waitangi grievances, attached to 23 May 1991, 'Structures for the resolution of Treaty of Waitangi grievances', CAB (91) M 19/17, T 13, OTS archive, for further detail about how these responsibilities were shifted post-election 261 Tribunal, The Ngai Tahu Report 1991 (Wai 27).
} 
in time it was recognised that to 'do nothing' was no longer an option. Too much attention was now on historical grievances and the government were determined to push on with plans to privatise Crown assets. But once committed the National government transformed the landscape; Douglas Graham recalled that over 300 papers on settlement issues were presented to Cabinet on Treaty settlement policy during the period 1991 to $1994 .{ }^{262}$

From 1992 the National government began to develop a long-term, coordinated strategy for the settlement of Treaty of Waitangi claims. It was conceived of as a 10year programme for addressing all historical claims (and this was released in December 1994 as The Crown Proposals for the Settlement of Treaty of Waitangi Claims). The concept of a settlement fund (later known as the settlement envelope or the fiscal envelope) was decided upon in 1992, although the details of it were not made public until December 1994. The government gave priority to defining the parameters of the historical grievances negotiation process and to deciding on the amount of money it was prepared to pay to settle those claims. The Treasury sought to set parameters around the amount of money that was to be spent on historical claims, as a means of providing certainty for government, the electorate and claimants, in that order. It will be argued that once the National government realised it needed to address historical claims it was highly motivated in seeking to contain settlements, both in terms of the amount of money and the length of time it was prepared to spend on them.

Another motivation for the National government to complete Treaty settlements was to give some assurance to the public that this process could be well managed and addressed quickly. The National government sought to strike a balance between recognising that historical grievances were genuine and yet not being perceived as being overly generous with compensation, as its traditionally conservative electorate would not support excessive spending on Treaty issues. A tension existed between those three key aspects: acceptability in the eyes of the public, fiscal responsibility and removing a sense of grievance for Māori.

${ }^{262}$ Interview with Sir Douglas Graham, 15 August 2012 
Officials advised ministers and Cabinet that Treaty issues needed to be addressed in a timely manner. Policy papers from the period refer to this situation as containing 'self-reinforcing uncertainties'; the need to balance the opinion of the conservative electorate who viewed the amount paid out in settlements as excessive (even though there were hardly any payments yet) and the growing recognition that to 'do nothing' was no longer an option. What officials were identifying could be described as the inherent tension of the Treaty settlements process. On the one hand pressure to find general public acceptability and ensure that any resulting policies were seen as 'fiscally responsible', yet on the other a need to offer durable settlements which would address the Māori sense of grievance for historical Crown actions. Ministers had come to recognise that a new policy approach was required, with the goal of a sustained improvement in race relations in New Zealand.

From early 1992 until their release in December 1994, the National Government worked on developing its policies for the settlement of historical Treaty claims. They were released as The Crown Proposals for the Settlement of Treaty of Waitangi Claims, in December 1994. Officials and politicians did the vast majority of this policy development without any contribution from Māori, apart from Māori public servants. Collectively and colloquially known as the "fiscal envelope", these policies became a symbol of discord in the relationship between Māori and the Crown. Māori were critical of the level of progress that the government had made on these issues without any wider discussion or room for genuine contribution by them. As the policies were being developed, there was ongoing reference to the need to consult with Māori on the details. What can be referred to as a 'culture of consultation' had been established in part from the adoption of free market, neoliberal policies under the fourth Labour government. It was now fairly standard practice for the State to seek to consult with community and 'stakeholders' on major issues. Initiatives such as the education reforms, resulting in 'Tomorrow's Schools', were examples of this. Although by the 1990s this type of consultation was commonplace, it did not necessarily follow that the consultation process impacted on draft policies. Some arguing that it was more of a box-ticking exercise. ${ }^{263}$ There had

\footnotetext{
263 see for example B Guy Peters and Donald J Savoie, ed. Taking Stock: Assessing Public Sector Reforms (Montreal: McGill-Queens University Press, 1998).
} 
been no consultation on settlement issues up to this point, but as officials were drafting policies and presenting them to Cabinet there were ongoing references that it was the intention to present these matters to Māori for consultation.

The fact that the government devoted so much time and effort into developing policy demonstrates the significant position the Treaty and the resolution of breaches had come to occupy in New Zealand in a short period. ${ }^{264}$ Yet, as this chapter demonstrates, there are few examples of a direct 'Māori voice' coming through from official sources and files. The Crown was in formal negotiations with Waikato-Tainui and beginning negotiations with $\mathrm{Ngāi}$ Tahu at this time. Other claimant groups, such as Te Ariki (wai 7), Ngati Te Ata (wai 31), and the Hauai claim (wai 200) were working towards a Final Agreement, while at least six more claims were on the formal negotiations register. ${ }^{265}$ All of this demonstrates that contact was occurring between those claimants and Crown officials during this period, although this was limited to specific claims, rather than on the wider policy framework.

\section{National Government in Power}

Although the National party had campaigned on attending to genuine historical Treaty claims, it remained somewhat conflicted about engaging with Treaty issues. National was uneasy at the extent to which Treaty principles had permeated legislation and the public service by this time, yet there was the acknowledgement of genuine Treaty claims and the negative socio-economic statistics in which Māori were over-represented. There was some belief that by attending to Treaty grievances Māori might better engage in society. At the time of the 6 November 1993 election, negotiations were already underway with Waikato-Tainui and the Waitangi Tribunal was finalising its substantial report on the Ngāi Tahu claims in preparation for release in early 1991 . The 1990 booklet the Direct Negotiation of

\footnotetext{
${ }^{264}$ This fits into Dominic O'Sullivan's theory that biculturalism has come to limit Māori, Dominic O'Sullivan, Beyond Biculturalism: The Politics of an Indigenous Minority (Wellington: Huia publishers, 2007).

26517 March 1992, CSC(92) 23, Memo for Cabinet Strategy Committee, 'The Crown's Obligations under the Treaty of Waitangi at 1992', 11
} 
Treaty claims was still in place, but the negotiations process was operating on a small-scale but without a definite budget to address settlements.

Little progress had been made on National's pre-election undertaking to address Treaty grievances and to remove references to the Treaty from legislation in the months after the election. ${ }^{266}$ Part of the delay in progressing and concluding the negotiations was that insufficient policy work had been done to develop a robust, clear process to address the many claims that had been registered with the Waitangi Tribunal. Briefings from TOWPU in November 1990 and March 1991 both demonstrate that the system in place was limited, and not equipped to progress multiple negotiations simultaneously. ${ }^{267}$ TOWPU officials expressed concern that in the post-election situation there was inadequate direction to officials from Government about the thrust of Treaty claims resolution policy beyond the preelection commitment to resolving the major claims within ten years. ${ }^{268}$ Graham later commented that Māori claimants were frustrated at the lack of progress on resolving claims, members of the public were not very well informed about the background to grievances (and were therefore not impressed), and 'Cabinet in early 1991 set out on a path fraught with difficulties at every turn.'269

In May 1991 Winston Peters was dismissed as Minister of Māori Affairs, and responsibility for Treaty negotiations returned to the portfolio of the Department of Justice. Douglas Graham, as Minister of Justice, also assumed responsibility as Chair of Cabinet Committee on Treaty of Waitangi Issues. ${ }^{270} \mathrm{He}$ was formally briefed in this role at the end of May 1991 and from that time there was an increased

\footnotetext{
${ }^{266}$ By this time over 20 pieces of legislation included references to the Treaty or principles of the Treaty.

2675 December 1990, Director TOWPU Memorandum for Minister of Justice; March 1991, Memorandum for Cabinet Committee on Treaty of Waitangi Issues: Report on current and suggested government approach and structures for resolution of Treaty of Waitangi grievances, attached to 23 May 1991, 'Structures for the resolution of Treaty of Waitangi grievances', CAB (91) M 19/17, T 13, OTS archive

26829 May 1991, Memorandum for Minister of Justice 'Papers before Cabinet Committee on Treaty of Waitangi Issues Schedule for 30 May', T1 50 1, OTS archive

269 Douglas Graham, "The Treaty and Treaty Negotiations," in The Bolger Years: 1990-1997, ed. Margaret Clark (Dunmore Publishing, 2008), 166.

27020 May 1991, 'Structures for the resolution of Treaty of Waitangi Grievances', CAB (91) M 19/17, T 13, OTS archive; Trick or Treaty?, 42.
} 
focus on progressing Treaty of Waitangi negotiations. ${ }^{271}$ The Prime Minister gave a speech at Turangawaewae Marae, on the $25^{\text {th }}$ anniversary of the coronation of the Māori Queen, Te Arikinui Dame Te Atairangikaahu in May 1991, during which he reiterated his government's commitment to resolving 'misunderstandings about the Treaty and to streamline the structures for resolving Treaty grievances.' He pointed out that this must be done for the good of all New Zealand, and would therefore operate within financial constraints, 'the Crown's cheque book' he said was not 'without limit.'272

TOWPU officials expressed concern to Graham that little or no progress had been made on the specific issues allocated to the office of Winston Peters. An example they cited was the pre-election undertaking to review the Principles for Crown Action, which had been allocated to officials at Manatū Māori by Winston Peters. TOWPU reported that little had developed and prospects for working out any new or revised versions seemed a long way off. ${ }^{273} \mathrm{~A}$ couple of months later the Cabinet Committee on Treaty of Waitangi Issues was presented with a review of the Principles and four possible options on how the government might approach them: repudiate, replace, modify or reaffirm. Officials favoured reaffirming the principles as they had worked well as an overarching framework. The Cabinet Committee 'directed officials to restate the existing five principles with modifications or explanations designed to conform with Government policy. ${ }^{274}$

Further, and more problematic in terms of National's undertakings, was what TOWPU identified as the main barriers to progress: 'government policy on Māori claims is not sufficiently developed to handle the issues in a consistent and coherent way. ${ }^{275}$ It would seem that various government departments held differing views on the value of settling claims. In July 1991, the same month Cabinet Committee on TOW Issues considered the paper on the Principles for Crown Action, the Prime Minister had asked Treasury to work out the cost Treaty Claims were having on

\footnotetext{
${ }^{271} 28$ May 1991, Briefing to Minister of Justice, 'Treaty of Waitangi Policy Unit - Status Report', TS 351 , OTS archive

${ }_{272}$ Cited in 17 March 1992, 'Memorandum for Cab Strategy Committee: The Crown's Obligations under the Treaty of Waitangi at 1992', CSC (92) 23, 23

27329 May 1991, TOWPU Memo for Minister of Justice, T1 50 1, OTS archive

${ }^{274}$ Palmer, The Treaty of Waitangi in New Zealand's Law and Constitution, 140.

275 June 1991, 'Memorandum: The Work of TOWPU and Implications for Structure'.3
} 
delaying government business, including asset sales. Treasury estimated the Crown's Treaty related costs in relation to asset sales and transfers as $\$ 205$ million. ${ }^{276}$ While this is a considerable amount of money, the more significant aspect appears to be the question the Prime Minister put to Treasury in the first place -as if 'normal' government business was being disrupted by the Crown's Treaty obligations.

\section{The Development of the 'Framework' Policies}

On 17 February 1992 Graham took a proposal to settle claims with Ngāi Tahu and Tainui as an oral item to a regular Cabinet meeting. ${ }^{277}$ In response, Cabinet invited the ministers to report back on the status of all negotiations to date and on an overall approach to claims resolution. ${ }^{278}$ The National government began to engage in some strategic thinking on Treaty claims. While Graham was motivated in the first instance by wanting to progress negotiations with the major claims of Waikato-Tainu and Ngāi Tahu, his Cabinet colleagues encouraged him to develop a broader base from which to approach all claims. ${ }^{279}$ Ministers had already agreed that to 'do nothing' was no longer an option; a comprehensive approach to claims settlement was needed. Over the next few months, Graham and his TOWPU officials prepared a number of papers for Cabinet Strategy Committee and Cabinet, which sought to establish a set of principles and parameters and to define provisions for negotiating and achieving settlements between Māori claimants and the Crown. Through this work issues of affordability, durability, definition of grievance, and mandating were considered and debated within government.

In the meantime different claims were at different stages of negotiation. Of the 271 claims registered with the Tribunal, at least 15 claims had been accepted onto the

\footnotetext{
27618 July 1991, The Treasury, Report to Minister of Finance Minister of State-owned Enterprises, 'Costs of Delays in Government Business due to Treaty claims'

${ }^{277}$ As it transpired, it was to take several more years of intense negotiations for either of these claims to reach settlement. For more on the details of the negotiation process for each see Fisher, "Balancing Rangatiratanga and Kawanatanga: Waikato-Tainui and Ngāi Tahu's Treaty Settlement Negotiations with the Crown."

27817 March 1992, Memorandum for Cabinet Strategy Committee: 'The Crown's Obligation under the Treaty of Waitangi at 1992', CSC(92)23; citing 17 February 1992, CAB (92) M5/18

${ }^{279}$ Ruth Richardson, Making a Difference (Christchurch: Shoal Bay Press, 1995), 148.
} 
direct negotiations register. ${ }^{280}$ Formal negotiations had resumed with Waikato-Tainui and in July 1991, as a gesture of goodwill, Cabinet had agreed to return the decommissioned military base Hopuhopu to Waikato-Tainui. ${ }^{281}$ The iwi decided that Hopuhopu would be vested in Pootatau Te Wherowhero, the first leader of Kingitanga, to generate a sense of unity among the hapū and to ensure the land was not able to be alienated. ${ }^{282}$ This was the first time that returned Crown land was vested in an eponymous ancestor, but the approach has now been taken on by other claimants as part of settlement arrangements. In September 1991, the Crown had entered formal negotiations with Ngāi Tahu, six months after the release of its Tribunal report. On 6 September 1991, around the time negotiations between Ngāi Tahu and the Crown commenced, the Waitangi Tribunal issued a supplementary report recommending the creation by statute of a representative tribal body for $\mathrm{Ngāi}$ Tahu, at Ngāi Tahu's request. ${ }^{283}$ In November 1991 Cabinet agreed on the details which were to be included in the Framework Agreement between Ngāi Tahu and the Crown.

Officials had been working behind the scenes on different options for ways to approach Treaty settlements. Graham presented these proposals in a 27 page memo to Cabinet Strategy Committee on 17 March 1992. The document reasoned that the government should state its position on how it would approach its Treaty obligations. It also asserted that Treaty issues were 'fundamentally political issues' and that government had a duty to deal with these matters by a policy-based approach to resolving grievances rather than leaving them for a 'strictly legalistic approach with the Courts providing adjudication. ${ }^{284}$ The adoption of a policy driven solution has come to define the New Zealand Crown's approach to settlements, but

\footnotetext{
28017 March 1992, Memorandum for Cabinet Strategy Committee: 'The Crown's Obligations under the Treaty of Waitangi at 1992', CSC (92) 23, 9-11

28123 July 1991, CAB (91) M31/20, TS 03, OTS archive

${ }^{282}$ Fisher, "Balancing Rangatiratanga and Kawanatanga: Waikato-Tainui and Ngāi Tahu's Treaty Settlement Negotiations with the Crown," 69.

283 Waitangi Tribunal, The Ngai Tahu Claim: Supplementary Report on Legal Personality (Wellington: Waitangi Tribunal, 1991).

28417 March 1992, Memorandum for Cabinet Strategy Committee: The Crown's Obligations under the Treaty of Waitangi at 1992, CSC (92) 23. It is notable how much of this material was consistent with that of the previous Labour government
} 
it is rare in the global experience of historical settlements with indigenous peoples. ${ }^{285}$ The report also noted that the inscription of the Treaty into 21 Government statutes could not now be easily reversed and they should remain in place. It was proposed that the structures and processes already put in by the Labour government would remain but there would be a change in attitude and focus, characterised by goodwill, the gifting of Hopuhopu to Waikato-Tainui was used as an example of this. 'Chiefs meeting with chiefs' was a further example of this new approach, meaning the Minister of Justice, supported by senior officials would regularly meet with senior claimants. This suited Douglas Graham's position as a senior minister and his affable personality and came to characterise his ministerial tenure. Speed and efficiency in the negotiating process and a desire to address the major claims first, were further initiatives which characterised this new approach. ${ }^{286}$ This March 1992 memo was a starting point for ongoing policy debate and formulation within government.

The work of the previous Labour government was acknowledged as having contributed 'significant steps' to resolve Treaty claims, 'most of which the current government confirmed in May 1991'.287 For example the establishment of TOWPU and the implementation of a negotiating process with three discrete phases (Framework Agreement, Agreement-in-Principle, and Final Agreement) and the establishment of a Negotiations Register were all acknowledged. These observations of the progress of the Labour government support the historical material, which demonstrates that the 1990 National government built on the processes already begun by Labour. It contrasts with Graham's later recollection that National 'started with a blank sheet of paper' on Treaty settlements. ${ }^{288}$

\footnotetext{
${ }^{285}$ R P Boast and D A Edmunds, "How Negotiations for Reconciliation Can Exacerbate Division as Well as Promote Reconciliation," in Reconciliation, Representation and Indigeneity: An international conference hosted by University of Mainz and Victoria University of Wellington (Wellington, March 2013), 3.

28617 March 1992, Memorandum for Cabinet Strategy Committee: The Crown's Obligations under the Treaty of Waitangi at $1992, \operatorname{CSC}(92) 23,11-12$

${ }^{287}$ ibid

28817 March 1992, Memorandum for Cabinet Strategy Committee: The Crown's Obligations under the Treaty of Waitangi at 1992, CSC(92) 23,.14; Graham, Trick or Treaty?, 42. Graham also made reference to progress of Labour in relation to grievances when discussing the interim fisheries settlement, saying Labour 'lifted the awareness of New Zealanders when they didn't want to hear'. 25 September 1992, 'Graham in tears as he reports on fishing deal', The Dominion
} 


\section{Historical Grievances vs Contemporary Problem-solving}

In May 1992 it was publically reported that the government was reassessing its approach to Treaty claims as it tried to contain costs and help Māori 'climb from the bottom of the economic heap.'289 In this report, the ambiguity and tension between resolving historical wrongs under the Treaty of Waitangi and addressing contemporary economic realities (such as unemployment) came to the fore. During the early 1990s, there was political concern that Māori were not fully participating in New Zealand society; in 1992, the unemployment rate was just over ten percent but Māori unemployment was over 25 percent. ${ }^{290}$ This was seen as a key indicator that Māori were not fully "engaging" with society, and was presented as a factor contributing to the view that the past should be addressed, in order for Māori to be in a position to fully participate. The Treasury advised its minister that Treaty settlements should not aspire to restore an economic base for Māori, rather that economic development for Māori would be better achieved through education and employment. It argued that there was a tipping point for settlements. If the Crown were too financially generous, it would have less to spend on 'programmes to enhance development of Māori in the future. ${ }^{291}$ From the Treasury perspective there was a clear trade-off between providing historical redress for Māori, under Article Two of the Treaty and yet also providing for Māori under Article three of the Treaty. The Treasury advised that the amount of compensation to be paid through negotiated agreements should be fair to all New Zealanders, future generations, and should 'encompass some level of the grievance. ${ }^{292}$ Meanwhile TOWPU was advising its minister that while Treaty claims might assist in promoting tribal development, compensation should be recompense for historical actions of the Crown under Article Two of the Treaty, social and economic policies should be considered separately. There was tension between the goals of Graham, as

\footnotetext{
${ }^{289} 18$ May 1992, 'Govt looks ahead on treaty claims', The New Zealand Herald

$290 \mathrm{http}: / /$ socialreport.msd.govt.nz/documents/the-social-report-2010.pdf, 51, accessed 30 October 2013

29118 May 1992, Treasury Aide Memoire, Treasury Advice on Crown Proposals for the Settlement of Treaty of Waitangi Claims, (released by Treasury under the OIA, 3 March 1995) hereafter referred to as Treasury Papers

29226 May 1992, T92/2890, 'Treaty of Waitangi Issues', Treasury Papers
} 
Minister of Justice and Ruth Richardson Minister of Finance and their departments at this time. Where TOWPU and Treasury differed was on how generous compensation should be. Richardson and her department were particularly 'anxious to restrain spending. ${ }^{293}$

\section{Introduction of the Ten-year Programme}

On 12 August 1992 Graham tabled a further memo to Cabinet Strategy Committee (CSC), which proposed a ten year programme plan for settling historical grievances under the Treaty of Waitangi, as an attempt to remain in step with National's election promises. ${ }^{294}$ The paper, later described a 'think-piece', pointed out the possible fiscal implications of historical claims, in particular that it was unlikely Māori would achieve economic and social parity while historical grievances were left unresolved, and yet that it would not be possible for the Crown to fund the total loss experienced by Māori. TOWPU officials argued that any settlements should seek to be 'durable through ensuring that the redress is fair, sustainable and contributes to the removal of any sense of grievance'. ${ }^{295}$ Another issue raised in the paper, which required further consideration was that of mandating, or the need for the Crown to be satisfied that it was negotiating with the proper claimant group. The repeal of the Runanga-Iwi Act (RIA) contributed to some of the later difficulties with mandating. Hill noted that even some opponents of the Act considered that problems relating to Maori representation, 'which were often to delay reparational negotiations and settlements, may have been avoided had the RIA been retained or reformed. ${ }^{296}$ The Solicitor-General was asked to report back on how this identification might be obtained. Most significant was the proposed establishment of a trust fund from which costs to settle historical grievances (except taonga and environmental claims) would be paid. It was suggested that the Crown trust fund receive $\$ 100$ million each

\footnotetext{
29318 May 1992, 'Govt looks ahead on treaty claims', New Zealand Herald

29412 August 1992, Memorandum for Cabinet Strategy Committee, 'Ten Year Programme of Settling Maori Treaty Claims', Yellow Book

29512 August 1992, Memorandum for Cabinet Strategy Committee, 'Ten Year Programme of Settling Māori Treaty Claims', para Q-AB Yellow Book

${ }^{296}$ Hill, Maori and the State: Crown-Maori Relations in New Zealand/Aotearoa, 1950-2000, 248.
} 
year for 10 years to pay for Treaty of Waitangi claims. ${ }^{297}$ This is the first clear reference to the concept of a trust fund, which later became known as the Settlement Fund or fiscal cap. The trust fund concept soon attracted scrutiny from the Treasury. As it briefed its minister on the progress of the Fisheries negotiations being undertaken at this time, it argued that the compensation for the fisheries settlement should be deducted from the recently announced trust fund:

In our view this Trust Fund should be comprehensive in its coverage, in order for the Crown to clearly contain its liability and hence its fiscal risk, and to avoid disputes about what should be funded from the package and what lies outside it. ${ }^{298}$

TOWPU officials did not support this position. They considered that the fishery settlement should be funded separately from settlements relating to land. ${ }^{299}$ Also of note, was the fact that many of the details of the trust fund had not been finalised and yet deductions were already being made from it.

Later in August the Prime Minister, Jim Bolger submitted a paper (which would have been drafted by officials from Department of Prime Minister and Cabinet) 'Principles for Settlement of Maori Claims', in response to Graham's ten-year programme memo. It contended that any negotiation process had to be fiscally manageable and that settlements had to be affordable in terms of the Government's fiscal and economic strategy and be broadly politically acceptable to the wider community. Bolger was also adamant that any settlements should mark the resolution of historical grievances. ${ }^{300}$ The inherent tensions of this approach were obvious; it was noted that it was 'unlikely that Maori will achieve parity economically and socially while grievances continue to exist', and yet it was considered 'unfair for current generation to bear all costs.' The Prime Minister noted that it was impossible to fund the total loss experienced by Māori and yet it was argued that redress should be fair, sustainable and contribute to removing a sense of grievance. In addition there was

\footnotetext{
29712 August 1992, Memorandum for Cabinet Strategy Committee, 'Ten Year Programme of Settling Māori Treaty Claims', para AD Yellow Book. It is of particular interest to note that the amount of money mentioned in this early document was the same amount eventually agreed to for the fiscal cap.

${ }_{298} 25$ August 1992, Treasury briefing to Minister of Finance, T1 33, OTS archive

299 Interview with former Crown official 2, 25 September 2012

30025 August 1992, 'Principles for Settlement of Maori Claims', CSC (92) M 36/2, T 5/2/1 vol.1, OTS archive. Claimants would also need to assure that the benefits from settlement will accrue to members of the claimant group for purposes consistent with the Government's broad objectives for Māori.
} 
seen to be a need to resolve valid claims as soon as possible, 'so that the honour of the Crown is restored without delay. ${ }^{301}$

Even as the policy was being developed, (and before the amount of the trust fund had been confirmed) the focus was on affordability for the country as a whole. Achieving this required compromise from Māori. It was well understood that the country was not in a position to offer full compensation for all that was lost, therefore any settlement required Māori to forfeit the return of much which they had lost for the sake of the country as a whole. In 1995, Waikato-Tainui claimed that the Crown offer of $\$ 170$ million was less than 2 cents in the dollar on what it had lost through raupatu. Likewise Ngāi Tahu noted that its land loss had been valued by its advisors at up to $\$ 16$ billion, yet it too agreed to settle its claims for the significantly lower figure of $\$ 170$ million. ${ }^{302}$ The fact that sufficient Māori claimants continued to engage in negotiations with the Crown indicated that Māori were willing to accept that compensation would not replace loss; yet there was very little wider society recognition of what claimants were to forfeit in order to agree to settlement with the Crown. Meredith Gibbs has also noted this, contending that while justice is the principal aim of the Treaty settlements process it is 'limited by cultural and temporal restraints'. ${ }^{303}$ Even at this early stage the government also highlighted the need for 'consistency and equity' between claimant groups, within the 'Crown's limited resources'. This reference highlights some of the difficulties the Crown would face in trying to establish and maintain relativities between claims, as it attempted to contain all settlements within a fixed cap, particularly given that the number and extent of historical claims was not known in 1992.

\section{Principles for the settlement of Māori claims}

In September 1992, a further paper was presented to Cabinet Strategy Committee. Entitled 'Treaty of Waitangi: Principles for Settlement of Māori Claims'. The paper

\footnotetext{
30125 August 1992, 'Principles for Settlement of Maori Claims', CSC (92) M 36/2, T 5/2/1 vol.1, OTS archive, Para q

${ }^{302}$ February-April 1995, Mana Magazine ; "Figure Wrong - Ngai Tahu," The National Business Review, 17 February 1995, 5.

${ }^{303}$ Meredith Gibbs, "Are New Zealand Treaty of Waitangi Settlements Achieving Justice? : The Ngāi Tahu Settlement and the Return of Pounamu" (PhD Thesis, Otago University, 2002), 46.
} 
was a culmination of Graham's August paper, the Prime Minister's paper and further work by officials and it set the parameters for the National government's approach to the negotiation and settlement of claims. ${ }^{304}$ Cabinet approved this paper on 21 September 1992. This was the key Cabinet paper which underpinned the direction of the National government as it worked, considered and refined its policy approach over the next two years.

A specific quantum amount was not mentioned in the policy documents at this time, officials considered that any decision on how much money was to be available as compensation was a political one, one that politicians would make the final decision on. Rather, the paper presented several key principles to guide the programme for settling historical grievances under the Treaty of Waitangi in the best interests of all New Zealanders. There was an acknowledged tension between doing right by Māori claimants and the need to 'avoid the risks of backlash' from the majority of the electorate, who are not Māori. ${ }^{305}$ The expectations and aspirations of Māori and the public were regarded by officials as being polar opposites, referred to in the paper as 'self-reinforcing uncertainties'. Also explicitly stated was the fact that the Crown was duty-bound to act in the interests of all New Zealanders and that any settlements should strive to be 'durable', yet fair and sustainable, removing a sense of grievance. $^{306}$ The paper explicitly stated that the country was not able to afford to compensate Māori for all that they had lost. There was also an explicit Crown acknowledgement that outstanding historical grievances existed, and further principle that any attempts to resolve outstanding grievances should not create another grievance.

From this early position, Cabinet made it clear that any settlement would include 'public and authoritative acknowledgement by the Crown and the claimant that the former acted honourably and reasonably, and that the settlement is to their mutual satisfaction.' $^{307}$ This aspect was subject to ongoing criticism from claimants and commentators. The Crown, as perpetrator of historical breaches of the Treaty and

\footnotetext{
${ }^{304} 21$ September 1992, Treaty of Waitangi: Principles for Settlement of Māori claims, CAB (92) M 38/11, Yellow Book

305 ibid

306 ibid

30721 September 1992, Treaty of Waitangi: Principles for Settlement of Māori claims, CAB (92) M 38/11, Yellow Book, para F i
} 
its principles, required that claimants agree that it was now acting honourably and reasonably. Aside from Māori public servants; it is hard to see where a Māori voice could be heard in this discussion.

\section{Fisheries Agreement September 1992}

At the same time as the development of these policies for historical grievances the negotiation and final settlement of the fisheries claims took place. The Fisheries Agreement was signed on 23 September 1992, two days after the significant Cabinet decisions on the creation of the settlement fund and the ten-year programme to settle all significant claims. ${ }^{308}$ This settlement, also known as the 'Sealord deal' was a pan-tribal agreement signed by over 80 tribal representatives. The settlement of $\$ 170$ million was used to enable Māori to acquire 50 per cent of Sealord Ltd, with Brierley Investments Ltd acquiring the other half, and provided for the Crown to transfer 20 per cent of quota of any new fish species to Māori. The Agreement also recognised and protected Māori customary fishing practices and established the Treaty of Waitangi Fisheries Commission/Te Ohu Kai Moana. The Treaty of Waitangi Fisheries Claim Settlement Act, passed 14 December 1992, confirmed the Deed of Settlement. ${ }^{309}$

The Fisheries agreement included a reference in clause 4.6 that the settlement would be deducted from a Treaty of Waitangi settlement fund. The settlement fund had only been approved by Cabinet two days prior to the signing of the Fisheries Agreement and no dollar figure had yet been specified. There was understandably some backlash to this last minute addition. Denise Henare, legal advisor to the Māori negotiators (and solicitor for the Tainui Māori Trust Board) had sought assurance that the amount paid for the fisheries settlement would not impact on the fiscal negotiations that were being undertaken with Waikato and Ngāi Tahu at that

\footnotetext{
308 See 28 June 1993, Treaty of Waitangi: Settlement of Claims, Overview Paper, CSC (93) M 27/1, 1993, T5/2 vol 4, OTS archive

${ }^{309}$ For more detail on the fisheries agreement see Ward, An Unsettled History: Treaty Claims in New Zealand Today, 46-51.; Moon, The Sealord Deal.; Richard T. Price, "Assessing Modern Treaty Settlements: New Zealand's 1992 Treaty of Waitangi (Fisheries Claims) Settlement and Its Aftermath," (Christchurch: Macmillan Brown Centre for Pacific Studies, 1996).; Hill, Maori and the State: Crown-Maori Relations in New Zealand/Aotearoa, 1950-2000, 254-5.;
} 
time. This assurance was given by Graham. ${ }^{310}$ Yet, as will be demonstrated, Denise Henare's concerns were proved correct. The Fisheries negotiation and subsequent settlement was recognised by the National government as its first negotiated settlement, and contributed to the framework for negotiations and settlement of land issues. ${ }^{311}$

Despite the fact that Graham, the TOWPU Director and other TOWPU staff were heavily involved in negotiations of the fisheries agreement there is very little reference to it within the TOWPU files. ${ }^{312}$ Following the pan-Mãori approach to the fisheries settlement there was brief reference to the possibility of a pan-Māori approach to land settlements. Sir Graham Latimer was quoted in the media at the time, supporting this initiative. Others, such as Tipene O'Regan were not keen and could see no benefit in a pan-Māori approach to land issues. ${ }^{313}$

\section{The Policy Debates Continue}

The September 1992 Cabinet decision was crucial for establishing the framework for the direction of the government's approach, but there was a great amount of detail yet to be considered. Issues like the purpose and the size of the Settlement Fund, what approach should be taken to natural resources dominated the work of ministers and their advisors for the next year or so. All policy work was suspended in the immediate lead up to the 1993 general election, but prior to that officials were busy working to address issues raised by Cabinet ministers. There was concern among ministers and officials that matters outside the control of the executive branch of Government could skew settlements. Of particular concern for the Crown were the Waitangi Tribunal's binding powers, which had the potential to alter any funding

\footnotetext{
${ }^{310}$ Fisher, "Balancing Rangatiratanga and Kawanatanga: Waikato-Tainui and Ngāi Tahu's Treaty Settlement Negotiations with the Crown," 120.

${ }^{311}$ Mason Durie, Nga Tai Matatu: Tides of Maori Endurance (Melbourne: Oxford University Press, 2006), 115.; P G McHugh, "Sealords and the Sharks: The Maori Fisheries Agreement 1992," New Zealand Law Journal (October 1992): 358.

${ }_{312}$ With the exception of reference to the settlement fund there was little (if any) reference to the Fisheries negotiation and agreement in the TOWPU files I have accessed. This is an area where future research may reveal further connections between the two processes.

${ }^{313} 25$ August 1992, Briefing to the Minister of Finance by The Treasury, Maori Fisheries Settlement: Sealord proposal, para 14, T1 33, OTS archive.
} 
priorities or relativities that were put in place by government. Officials advised that 'the settlement fund could blow out if the Tribunal directed the return of assets in excess of the settlement fund size. ${ }^{314}$ It was also proposed that a cut off date for registering claims with the Waitangi Tribunal should be introduced; there was quite some discussion on when this should be. ${ }^{315}$ There was also concern that the money generated by CFRT could also distort the fund. In relation to CFRT, officials advised Graham that if compensation were paid from the Trust it too could 'distort settlement relativities' if compensation was more than Government was expecting. ${ }^{316}$

The size and the composition of the settlement fund continued to be debated in the months from April through to June 1993. The Treasury noted that the size of the Settlement Fund would be lower than some would be expecting, and would thereby reduce the 'inflated expectations' of many claimants. Yet it was also observed that the settlements would only be 'durable' if claimants considered individual settlements as being fair. It was necessary for the settlement fund to achieve a balance between claimant expectations and acceptance with the wider community. Treasury's observations here are revealing and foreshadow some limitations of the Settlement Fund, even before it had been officially established. A further issue that was debated internally was whether the Treaty settlement process should be controlled by policy or statute. ${ }^{317}$ TOWPU recommended that the process should be controlled by policy, leaving ultimate responsibility with the Crown. ${ }^{318}$

There are frequent references through these papers to the need for consultation with Māori on the role and function of the settlement fund, and accompanying policies. For example, officials were asked to report back to Cabinet Strategy Committee by

\footnotetext{
${ }^{314} 27$ October 1992, TOWPU Ministerial Briefing paper, 'Treaty of Waitangi Settlement Fund: Size, shape, and Timescale, 4, in Treaty of Waitangi Policy Unit Ministerial Briefing Papers on Crown Proposals for the Settlement of Treaty of Waitangi Claims, released under the OIA 31 March 1995, hereafter referred to as TOWPU Papers

315 If 3 year limit on filing historical claims was implemented there would be an expectation that the Tribunal would need to be suitably resourced; See for examples Treaty of Waitangi Settlement Fund: Aide memoire, 17 November 1993, TOWPU Papers

${ }^{316} 27$ October 1992, TOWPU Ministerial Briefing paper, 'Treaty of Waitangi Settlement Fund: Size, shape, and Timescale, 3. TOWPU Papers

${ }_{317}$ See 27 April 1993, 'Treaty of Waitangi Claim Settlement Fund: Follow-up to meeting 7 April 1993'; 13 May 1993, 'Treaty of Waitangi Claim Settlement Envelope', TOWPU Papers

${ }^{318} 29$ June 1993, Briefing to Minister of Justice, 'Brief on 'Treaty of Waitangi claim Settlement Fund: Size, shape, Timescale and the reciprocation from Maori', TOWPU Papers. TOWPU also argued that the Fisheries settlement should be excluded from the settlement fund
} 
16 December 1992 and again on 1 March 1993 to provide advice on what ministerial consultation with Māori leaders on the settlement fund might look like. ${ }^{319}$ The Officials Committee was also asked to report on proposals for involving Māori leaders in advising the Crown on relativities between grievances and claimant groups. All of this clearly signalled that there would be some kind of Crown-claimant discussion on the details of the settlement fund at this stage of policy development. Treasury advised that the overall quantum of the fund would be a judgement call, and any one individual settlement larger than the fisheries settlement was likely to be viewed by the wider community as being very large and, therefore, unacceptable, which would mean that a 'quantum larger than $\$ 800$ million including the fisheries settlement may not be acceptable to the wider community. ${ }^{320}$ Initially officials advised that the way the fund was presented would be a key aspect of whether it would be acceptable to Māori and non-Māori. ${ }^{321}$ A few months later, in June 1993, the issue was raised again: 'it is important that the Government has sufficient assurance from Māori that the concepts are viable and likely to be achieved in the timeframe. ${ }^{322}$ There was some ambivalence about the consultation:

while the settlement concepts have been signalled in a general way, and soundings have been taken with key claimants, wider consultation with Māori has not taken place to date.

It was recognised that consultation should take place in order for the government to ensure that it was acting within the principles of the Treaty when reaching a position on these issues. The Solicitor General had previously indicated 'that the Government has a duty to inform itself of the Māori perspective.' Crown Law considered that definitive decisions on settlement policy must await consideration of the Māori perspective. ${ }^{323}$ This issue of consultation (or lack thereof) generated a great deal of ill-will between Crown and Māori when these policies were finalised

\footnotetext{
3193 March 1993, Treasury Aide memoire, 'Treaty of Waitangi Claim Settlement Fund: Size of Fund', Treasury Papers

3203 March 1993, Treasury, Aide memoire 'Treaty of Waitangi Claim Settlement Fund: Size of Fund', Treasury Papers. This figure of no single settlement being larger than the Fisheries Settlement (of $\$ 170$ million in 1992) has been borne out over time.

${ }^{321} 25$ March 1993, 'Treaty of Waitangi Claim Settlement Fund: Presentation and perceptions', TOWPU Ministerial Briefing papers on Crown Proposals for the settlement of Treaty of Waitangi Claims, TOWPU papers.

${ }^{322} 28$ June 1993, Treaty of Waitangi: Settlement of Claims Overview Paper, CSC (93) 89, Yellow Book ${ }^{323}$ ibid
} 
and finally presented as The Crown Proposals for the Settlement of Treaty of Waitangi Claims in December 1994.

\section{Historical and Contemporary Claims}

In July 1993 Cabinet had agreed that the costs of settlement of all historical claims would be charged to the settlement Fund. It was therefore necessary to make the distinction between historical and contemporary grievances. ${ }^{324}$ Some debate followed, as to how 'historical claims' and 'contemporary claims' should be defined and which date should be used as the cut off between the two types of claims. Some possible suggestions floated were the date in 1985 that the Waitangi Tribunal's jurisdiction was extended back to 1840; or the date the Treaty of Waitangi (State Enterprises) Act 1988 came into force, or 30 June 1996, which was the proposed date that all historical grievances must be registered with the Waitangi Tribunal. ${ }^{325}$ The date of 21 September 1992, which had been the date that Cabinet had agreed to the framework approach for the settlement of claims, was the date retrospectively approved as the cut off date for historical claims. ${ }^{326}$ This date did not hold any other significance, but has often been misrepresented as the date of the signing of the Fisheries Settlement. As noted above, the Fisheries Deed of Settlement was in fact signed two days later on 23 September 1992. The paper recommending this date as dividing line between the types of claim was agreed to by Cabinet on 21 July 1993. ${ }^{327}$ Ministers and officials were also considering options for ways the Crown could approach claims relating to natural resources, including lakes and rivers, geothermal resources, the conservation estate. ${ }^{328}$ Matters of claimant representation were also being taken into account in these internal Crown papers, all of which indicates the level of detail in the discussions and debates by

\footnotetext{
32419 July 1993, 'Treaty of Waitangi Fund: Further Issues', CSC (93) 123, Yellow Book; 16 July 1993, Inter-office memo to Treasury from TOWPU, T5/2 4, OTS archive

${ }^{325}$ That proposed date to register all historical claims was not enforced.

${ }^{326}$ Settlements, Ka Tika A Muri, Ka Tika Ā Mua: Healing the Past, Building a Future. A Guide to Treaty of Waitangi Claims and Negotiations with the Crown, 24.; 21 September 1992, 'Principles for Settlement of Māori Claims', CAB (92) M 38/11, Yellow Book.

32721 July 1993, CSC (93) M 30/5, Yellow Book

328 February 1993, 'Additional Item: Treaty of Waitangi General Issues; minor claims', CAB (93) M $3 / 11$, Yellow Book Other papers relating to development of natural resources policy include 25 May 1993 TOW (93) M 4; 30 June 1993 CSC (93) M 27/2; 5 July 1993 CAB (93) M24/24. There were at least five papers prepared for Cabinet committee and Cabinet on Natural Resources in 1993, included in Yellow Book
} 
officials and ministers. There was little public engagement in these issues at this stage.

As demonstrated, a significant amount of thought and energy had gone into developing draft policies in 1992 and 1993, but the government determined that it was not in its interest to release any policy details in an election year. It was judged that Treaty issues were still too sensitive to be a central political item in the lead up to the general election. ${ }^{329}$ Cabinet agreed to suspend any further decisions on these policy issues until after the election of 6 November 1993 and all work was set aside until after then. ${ }^{330}$

\section{The Authority of the Tribunal and the Settlement Fund}

The role and function of the Waitangi Tribunal were being sidelined to a certain extent by the National government in this period. While the reports of the Tribunal provided a valuable new insight on New Zealand's history and a growing interpretation of the Treaty, there was concern about the length of time it was taking for the Tribunal to release those reports following an inquiry. All claims, even those with an accompanying Tribunal report, still needed to be negotiated with the Crown at some point.

The government was also wary of the claw-back provisions in the legislation governing the Tribunal. As discussed above, the concern was that if the Waitangi Tribunal could order the return of land to claimants, the government would not be able to contain the amount spent on settlements. It was therefore proposed that the Treaty of Waitangi Act be amended to take that power away from the Waitangi Tribunal. Interestingly, the Tribunal itself only referred sparingly to these powers. ${ }^{331}$ Cabinet decided in July 1993 that 'the Treaty of Waitangi Act should be amended so that claims relating to historical grievances must be filed with the Waitangi Tribunal

\footnotetext{
${ }^{329}$ Richardson, Making a Difference, 149.

${ }_{330} 27$ September 1993, 'Report backs due to the Cabinet Strategy Committee on Treaty of Waitangi Issues', CAB (93) M 36/9 (3a), includes a list of Cabinet papers on settlement policies held back until after the election, see also 8 February 1994 letter from TOWPU to the Solicitor-General, Crown Law Office on Treaty of Waitangi Claim Settlement Fund, T5/2 4, OTS archive; 'You will be aware that Cabinet held this issue in abeyance until after the parliamentary elections'. .

${ }^{331}$ Hill, Maori and the State: Crown-Maori Relations in New Zealand/Aotearoa, 1950-2000, 227.
} 
by 30 June 1996. ${ }^{332}$ Cabinet amended this on 31 October 1994, to say that a date should be worked out in the process of consultation. ${ }^{333}$

The government had expressed concern during the Ngāi Tahu hearings that it had no control over the findings the Tribunal would make in relation to the large South Island claim. Despite the fact the Tribunal could make recommendations only, there was a sense that claimant expectations might be elevated by the findings. Likewise, in 1991 the Tribunal released its report on the Te Roroa inquiry in which it recommended the return of land which should have originally been set aside from a Crown purchase, but had been in private ownership since the late nineteenth century. The recommendation was that former Māori reserves, some of which were now held in freehold title and in good faith, should be returned 'no matter what the cost'. ${ }^{334}$ Graham accused the Tribunal of failing to adhere to the principle of trying to resolve historical grievances without creating new ones. As a result in July 1993 The Treaty of Waitangi Amendment Act 1993 was passed to amend the Tribunal's powers of recommendation. A new subsection stated that the Tribunal could not recommend the return to Māori ownership any land in private ownership or the acquisition by the Crown of any private land. This allayed, to some degree, landowners' fears over the issue.

\section{Chapter Conclusion}

The period of 1991 through to 1993 had been of rapid policy development in relation to historical Treaty claims. In this period, some significant measures were introduced which built on those of the previous Labour government. Graham sought to address long-standing historical grievances and his officials advised him on how this might be achieved. Minister of Finance, Ruth Richardson sought to contain the process by implementing clear parameters and guidelines. The official record, including material publically released under the Official Information Act in 1995

\footnotetext{
33230 June 1993, 'Treaty of Waitangi: Settlement of Claims: Overview paper', CAB (93) M 24/13 (94) para (q), Yellow Book

${ }^{333} 31$ October 1994, 'Booklets for the consultation process on the Crown's proposals for the settlement of the Treaty of Waitangi claims', CAB (94) M 43/5

${ }^{334}$ Tribunal, Te Roroa Report (Wai 38), 305. see findings 8.1.2 and 8.1.3.
} 
demonstrates the degree to which ministers and officials were actively engaged with this process prior to the November 1993 general election. ${ }^{335}$ The fact that none of this policy development was discussed in the lead-up to that election is an indication that Treaty settlement issues were still politically volatile and that while Crown officials and ministers were working on quite a complex level on these issues, there was very little direct input from Māori (or the public) in this development. It is not possible to gain a sense of a Māori voice or Māori reaction to these developments and while there was acknowledgement of the need to consult with Māori, it was not acted on. The Crown considered that the presentation of a specific set of proposals would concentrate the issues, and that without these any period of consultation would experience delays. Provided the consultation process was open-minded and carried out in good faith any proposed policies could be altered and modified as a result of feedback.

\footnotetext{
${ }^{335}$ Policy Papers for Crown Proposals for the Settlement of Treaty of Waitangi Claims, (released by Office of Treaty Settlements under OIA, 3 March 1995) (Yellow Book); Treaty of Waitangi Policy Unit Ministerial Briefing Papers on Crown Proposals for the Settlement of Treaty of Waitangi Claims, released under the OIA 31 March 1995, (TOWPU Papers); Treasury Advice on Crown Proposals for the Settlement of Treaty of Waitangi Claims, (Treasury Papers)
} 


\section{CHAPTER FOUR: FINALISING THE CROWN PROPOSALS 1993-1994}

Draft government policy designed to address and settle historical Treaty grievances continued to develop between November 1993 and December 1994. In December 1994 the draft policies were released to Māori and the wider public as the Crown Proposals for the Settlement of Treaty of Waitangi Claims. The suite of policies were designed to comprehensively recognise legitimate historical Treaty grievances and address them in a transparent process of direct negotiations between claimants and the Crown, culminating in deeds of settlements. ${ }^{336}$

In 1991 the government had committed to addressing those historical grievances under the Treaty of Waitangi by developing a comprehensive set of policies designed to acknowledge legitimate grievances and offer compensation from a settlement fund to a recognised, defined Māori claimant group. The result was a response that was unique to New Zealand, fitting with Ken Coates' argument that all solutions to 'indigenous-government conflict must fit within national, political, economic and social frameworks. ${ }^{1377}$ This is also supported by Dominic O'Sullivan who also states that Māori, as a 'minority indigenous group', face power limitations in their relationship with the state. ${ }^{338}$ Graham recalled that the lead up to the release of the Crown Proposals was an intense one for officials and ministers, as they sought Cabinet direction on the draft polices. The emerging process was established as a policy-driven process and the resulting settlements were political settlements. While a lot of the policy groundwork had already been drafted in mid-1993 the National government decided to suspend any further work (and not to publicise information on progress) in the lead up to the November 1993 general election.

\footnotetext{
${ }^{336}$ Office of Treaty Settlements, Crown Proposals for the Settlement of Treaty of Waitangi Claims: Summary (Office of Treaty Settlements, Department of Justice, 1994 ).

${ }^{337}$ Ken S. Coates, "International Perspectives on Relations with Indigenous Peoples," in Living Relationships, Kōkiri Ngātahi: The Treaty of Waitangi in the New Millenium, ed. Ken S. Coates \& P.G. McHugh (Wellington: Victoria University Press, 1998), 77.

${ }^{338}$ O'Sullivan, Beyond Biculturalism: The Politics of an Indigenous Minority, 76.
} 
Following its re-election, the incumbent National government turned its attention to finalising policies, which were to be released for consultation with Māori and the wider public. This chapter analyses the details of their final policy decisions, including those on claimant representation, natural resources, the conservation estate, and the establishment of the settlement envelope. Ministers and officials worked to establish procedures and define the process that would govern negotiation and settlement of historical breaches of the Treaty. While some officials involved in policy formulation were also engaged in negotiations with claimants and Graham himself was regularly meeting with Tainui and Ngāi Tahu representatives and other claimants during this period, the majority of the claimants of the 450 registered claims had very little knowledge of, let alone input into the policy development. Officials and Cabinet ministers were essentially carrying out these debates and conversations in a vacuum. Aside from the occasional media coverage or leaked political document there was very little opportunity for Māori to interact with the process or to understand the level of changes proposed. ${ }^{339}$ Māori were at the very least denied agency in this process, and found themselves somewhat on the sideline of a significant re-interpretation of the Treaty rights in contemporary New Zealand so it is little wonder that the draft proposals faced such strong opposition when they were released. The Crown was concerned that consultation with iwi without first establishing baseline policies would have been time consuming and costly.

The National government considered that settling historical Treaty claims, within certain parameters and a particular budget, would not only address historical grievances, but also put Māori in a position to fully engage with and contribute to society. The settlement fund and the $\$ 1$ billion cap were presented as a nonnegotiable, for- information-only basis, at the same time as the draft policies. Māori were highly critical of the fiscal envelope, claiming that its arbitrary introduction was not the action of a considerate Treaty partner. They also argued that $\$ 1$ billion was an insufficient amount to settle all historical claims. There was further criticism for the draft policies of the Crown Proposals, namely that the policies did not go far

\footnotetext{
${ }^{339}$ See for example, 6 July 1994, 'Maori business 'down drain”, The Dominion.; Ranginui Walker, "Te Karanga: Pushing the Envelope," Metro Magazine, September 1994.
} 
enough and that they had been developed to such an extent before they were released. Although they had been released as draft policies open to feedback. On the other hand some Pākehā were critical of the Treaty settlement process and the large amount of money being spent on events that had taken place before they were born. ${ }^{340}$ Opinion polls demonstrated that the vast majority of New Zealanders believed Māori were already getting a 'fair go' in this country and saw no need to even embark on settlements. ${ }^{341}$ This chapter analyses the details of the draft policies that were developed and the lead up to their release at the end of 1994 .

During this period, Māori were increasingly looking to the Tribunal to undertake detailed historical inquiries and make recommendations to government on historical claims. Many claimants welcomed the opportunity to have historical grievances aired in an open and transparent way. Through this period, however, there was a sense that the Waitangi Tribunal's contribution was being downplayed and even sidelined by the government. The Waitangi Tribunal reported that its activities were hampered due to the restrictions of funding limitations. ${ }^{342}$ In 1993, the Waitangi Tribunal commissioned the Rangahaua Whanui project in an attempt to understand the impact of Treaty breaches in different regions throughout the country. This was in part a response to the government's settlement envelope concept. There was concern from some historians that the full extent of historical claims were not well understood and yet settlement costs were beginning to be deducted from the settlement fund. This chapter refers to the formal negotiations with Waikato-Tainui and Ngāi Tahu, which were reaching a critical stage during 1994. At the time of the release of the Crown Proposals, Waikato-Tainui was adamant that its decision to go ahead with signing a Heads of Agreement with the Crown was not a sign of support for the fiscal cap or the Crown Proposals, but was a matter of the timing being right for their own iwi.

\footnotetext{
${ }^{340}$ For discussion see Hill, "Anti-Treatyism and Anti-Scholarship: An Analysis of Anti-Treatyist Writings."

${ }^{341} \mathrm{~A}$ Listener/Heylen Monitor poll in a survey of 1,000 adults found that over $70 \%$ of those agreed Māori 'get a fair go in this country', 17 December 1994, The New Zealand Listener, 13.

${ }^{342}$ Te Manutukutuku Waitangi Tribunal Division Department of Justice Newsletter, no. 26, December 1993
} 


\section{The 1993 General Election}

Treaty issues and race relations were a dominant issue for the National government in the lead up to the general election of November 1993. Māori development was one of six election issues identified as priority by the National party, and it asserted that both Māori and the government were keen to move as quickly as possible beyond a focus on grievance and wrong-doing. The Government reaffirmed its commitment to settling all major claims by the end of the century. ${ }^{343}$ Although it pointed to genuine progress on the resolution of Treaty grievances, no mention was made of the potential establishment of the settlement envelope or of other policy work that had been going on since $1991 .{ }^{344}$ Opposition parties did not appear to give Treaty settlements quite the significance they had at the 1990 election. The Labour Party's manifesto for the 1993 election titled Jobs. Health. Growth, gave an indication of the priorities of the party at the time. The resolution of historical Treaty claims was not even at the top of the list of 'Māori issues', but came in behind employment and better land utilisation. ${ }^{345}$

The election resulted in National being returned to government with only a slim majority. A year earlier, in September 1992, a non-binding referendum had been held on the preferred electoral system for New Zealand, the first past the post (FFP) status quo or an alternative system. An overwhelming number of voters opted for change, and the majority of those chose Mixed Member Proportional (MMP) representation as the preferred system. A binding referendum was held at the time of the 1993 general election, with the choice being between the existing FPP and MMP. Fifty-three percent of voters opted for MMP; the New Zealand electoral system was therefore about to change fundamentally. The uncertainties of how MMP and a resulting coalition government might affect the development of policy were part of the political backdrop of this period.

\footnotetext{
${ }^{343}$ New Zealand National Party, Manifesto '93: Stepping out on the Path to 2010: The Spirit of Recovery (Wellington: New Zealand National Party, 1993), 24-5.

${ }^{344}$ This omission was noted 28 October 1993 'Maori Treaty claims still a priority', The Dominion ${ }^{345}$ New Zealand Labour Party, Jobs. Growth. Health: Labour's Manifesto for New Zealand 1993 (Wellington: GP Publications Ltd, 1993), 12.
} 
Graham was again given responsibility for Treaty settlements, under the new portfolio of Minister in Charge of Treaty of Waitangi Issues. ${ }^{346}$ The main focus for TOWPU after the election was to develop and finalise the government's position on claims relating to natural resources and other policies, as these had not yet been finalised. TOWPU reminded Graham that the previous Minister of Finance had advocated enshrining the settlement fund in legislation. ${ }^{347}$ TOWPU suggested instead that 'the newly constituted Cabinet may wish to re-visit the question of whether the fund can function equally well as a fiscal management tool with key data on claim relativities held in a select few ministerial safes'. This refers to a list, complied in some haste, by senior Māori advisors to Graham. It apparently recorded the major claims and indicated a comparative value to each other. It was claimed that the list, which became known as the 'Richter scale' was kept in a safe in Graham's office. ${ }^{348}$ Clearly, TOWPU and the Minister favoured an executive-based, rather than a legislative based approach. In relation to the Waikato-Tainui negotiations, TOWPU noted that a decision would have to be made on whether the Crown should continue with negotiation and settlement of the Tainui raupatu claim or whether all of their claims should be negotiated and settled at the same time.

A briefing to the new Minister of Finance, Bill Birch (who had replaced Ruth Richardson following the 1993 election) provides a Treasury perspective on the progress at this time. Treasury advised Birch that outstanding matters of policy needed to be addressed before a comprehensive government approach could be finalised, and that this should be done prior to settling any further claims. In particular, it pointed to the need to complete the policies on natural resources, the use of the conservation estate in claims' settlement; and the specifics of the trade off (or 'quid pro quo') for establishing the settlement fund. ${ }^{349}$ Treasury signalled that

\footnotetext{
${ }^{346}$ This was a new responsibility but did not hold a warranted at this time.

34710 December 1993, TOWPU Briefing to Minister of Justice, T 5/2 5, OTS archive.

${ }^{348}$ The above reference suggests that TOWPU considered that in the future this information could be made more widely available. Interview with former Crown official 1, 3 November 2014. Sir Douglas Graham made passing reference to the existence of the Richter scale in 2012, although was not specific about its content; Interview with Sir Douglas Graham, 15 August 2012.

${ }^{349} 8$ December 1993, 'Update on the Resolution of Treaty of Waitangi Claims' memo to Minister of Finance, Treasury papers
} 
given the long-term nature of establishing a settlement fund, support from the other political parties would be required to make progress on these issues. ${ }^{350}$

\section{The Government and the Waitangi Tribunal}

At times throughout this period, it seems the government was quite preoccupied by the activities of the Tribunal, particularly with the potential of its mandatory powers. The Tribunal was also moving into new territory with the content of its inquiries and the recommendations in its reports. As previously noted, the recommendations of the Te Roroa Report, were an example of this. In that report the Tribunal made the unprecedented move to recommend the return of land which was now in private freehold ownership, to Te Roroa. The Tribunal investigation revealed that areas that were intended to be reserved from the Crown purchases had not been set aside. An official investigation in 1942 had recommended that the reserves at Manuwhetai and Whangaiariki should be returned, 'no matter what cost to the Crown this may involve'. The Waitangi Tribunal endorsed this sentiment. ${ }^{351}$ Although the details of this recommendation were specific to time and place, the finding it made in relation to freehold land was a first and opened unchartered territory for the Waitangi Tribunal. Many private freehold land owners were already nervous about the Waitangi Tribunal process, and now grew more concerned about the implications of such a finding for their own land. Graham, conscious of the reaction of some Pākehā landowners, was critical of the Tribunal and noted that the report 'created a spark in what was already a tinder dry situation. ${ }^{352}$ This recommendation created real tension on the ground in the Far North, and took many years for the government to resolve. The Tribunal's powers were amended to prevent the Tribunal making recommendations including private land, as the Treaty of Waitangi Amendment Act 1993. ${ }^{353}$ The Muriwhenua inquiry was held between August 1990 and June 1994.

\footnotetext{
${ }^{350}$ Reference to a bipartisan political approach in 21 September 1992, 'Principles for Settlement of Maori Claims', CAB (92) M 38/11, Yellow Book

${ }^{351}$ Tribunal, Te Roroa Report (Wai 38), 292.

352 Graham, Trick or Treaty?, 52.

353 The Treaty of Waitangi Amendment Act 1993
} 
The inquiry into the Taranaki raupatu took a similar length of time. ${ }^{354}$ Both of these inquiries traversed new ground for the Tribunal; the Muriwhenua inquiry put new emphasis on oral testimony and on Māori concepts of early Crown land purchases. The Taranaki report stressed the ongoing impact of the Taranaki wars into the present, and the significance of Māori autonomy as 'pivotal to the Treaty and to the partnership concept it entails'. ${ }^{355}$

At the same time, Crown officials were concerned that the resumption powers of the Tribunal posed a 'risk' to the settlement envelope. If the Waitangi Tribunal could order the return of land to claimants, the government would not be able to contain the amount spent on settlements. ${ }^{356}$ This was reference to the authority the Tribunal had over State-owned Enterprise land, Crown forest land, and formerly owned railway land. ${ }^{357}$ The Tribunal alone had the power to decide whether resumption should occur and any findings would be binding on the Crown. While it had not used these powers and indeed only referred to them sparingly, their very existence meant that the Crown was not able to control all aspects of potential cost of the Treaty settlements process, as it would have preferred. ${ }^{358}$ At the end of 1993, the Tribunal reported that despite the growing number of claims, funding constraints were limiting its activities and progress. ${ }^{359}$ There was a growing divide between the historical inquiry and recommendatory process of the Waitangi Tribunal, and the process of direct negotiations for those claimant groups who were ready and wanted to proceed.

\footnotetext{
${ }^{354}$ Waitangi Tribunal, Muriwhenua Land Report (Wai 45) (Wellington: Waitangi Tribunal, 1997); The Taranaki Report: Kaupapa Tuatahi, Wai 143.

355 The Taranaki Report: Kaupapa Tuatahi, Wai 143, 5.

356 The Crown proposed the eventual removal of all memorials in its policy proposals, Settlements, Crown Proposals for the Settlement of Treaty of Waitangi Claims: Detailed Proposals.

${ }^{357}$ Geoff Melvin, "The Jurisdiction of the Waitangi Tribunal," in The Waitangi Tribunal: Te Roopu Whakamana I Te Tiriti O Waitangi, ed. Janine Hayward and Nicola R Wheen (Wellington: Bridget Williams Books, 2004), 25.

${ }^{358}$ Hill, Maori and the State: Crown-Maori Relations in New Zealand/Aotearoa, 1950-2000, 227.

359 Te Manutukutuku Waitangi Tribunal Division Department of Justice Newsletter, no. 26, December 1993
} 


\section{The Establishment of the Settlement Envelope}

By late 1993 there were further outstanding details to be finalised, such as the amount of money available for settlements, and how land-banks would affect the settlement fund, as well as the mechanics of how the settlement fund would be administered. Final decisions were yet to be made on issues of claimant representation, the Crown's approach to natural resources and whether they would be returned as part of a settlement, how claims to land included in the Conservation Estate were to be dealt with, and how the consultation process on all of the draft policies would proceed. ${ }^{360}$ The following section sets out the final policy decisions on each of these categories, released as part of the Crown Proposals in December 1994. It had been anticipated that policies relating to historical claims, the Public Works Act and the impact of the Native Land Court (and related Native Land Laws) would be included in this suite of policies but these were not completed in time. The issues were set aside to be considered after the release of the Crown Proposals. Despite these questions, the claims were still to be 'settled from the total amount in the Envelope. ${ }^{361}$

In September 1992 Cabinet had agreed on the concept of a settlement fund from which to pay compensation for all historical claims. In July 1993, Cabinet had agreed that the settlement fund would be established in legislation and annual instalments would be set aside for 10 years. ${ }^{362}$ Details of the how the settlement fund would be administered and the amount of money that would make up the fund were considered as two separate issues. While officials provided ongoing advice on the mechanics of the fund, the size of the fund was considered a political issue for Cabinet alone to decide. ${ }^{363}$ By this time, officials and ministers were familiar with the concept of the envelope, and were engaged in discussions about its limitations, but the majority of Māori claimants were unaware of these details. Martin Fisher has

\footnotetext{
3601 March 1994, 'Settlement of Treaty claims: outstanding policy and consultation issues' CSC (94) 12, OTS archive

${ }^{361}$ Settlements, Crown Proposals for the Settlement of Treaty of Waitangi Claims: Detailed Proposals, 10.

36221 September 1992, 'Principles for Settlement of Maori Claims', CAB (92) M 38/11, Yellow Book

36327 June 1994, 'Detailed Definition and Implementation of the Treaty of Waitangi Settlement

Envelope', CAB (94) M 23/20, para S, Yellow Book. Although I understand that Officials were asked to provide advice to their ministers on a one-off basis on the size of the envelope (see below) I have not been able to locate any further official documentation on this aspect.
} 
referred to a private pan-Māori hui attended by Waikato-Tainui, Ngāi Tahu and other iwi in Rotorua in February 1994 which Graham and Minister of Māori Affairs John Luxton were recorded as attending. According to Fisher, at the hui, Graham announced that the settlement envelope would be $\$ 1$ billion, which included the fisheries settlement. It is difficult to assess the veracity of this revelation. ${ }^{364}$ It should be pointed out that Cabinet was months away from making a formal decision on the size of the settlement fund, so it is unclear on what level of certainty Graham presented this information. ${ }^{365}$ It is unclear how many iwi representatives were in attendance at the hui. There do not appear to have been any Crown officials in attendance, nor were any media present. Although there had been some public references, in the media, to ongoing government work on policies including the settlement fund there was a great deal of uncertainty around the details. It is likely that major claimants, engaged with the Crown such as Waikato-Tainui and Ngāi Tahu had been privy to more information than claimants who were not yet engaged in the negotiations process. ${ }^{366}$ This lack of inside knowledge among Māori was evident in a planned Māori protest in April 1994 over concern that Treaty of Waitangi claims might be lumped together in a global Sealord style settlement. ${ }^{367}$

In April 1994 Graham asked the Cabinet Strategy Committee to revisit the decision to enshrine the settlement envelope in legislation, and instead consider a 'more flexible budget, or target, implemented by Government policy alone.. 368 There were pros and cons to both approaches. One of the arguments against fixing the cap in law was that the use of legislation could be an incentive for Māori to bring court action or appeal to the Waitangi Tribunal; in other words, establishing the cap in legislation would enable Māori to access the legal (and Tribunal) system to challenge the process if they wished. It was also argued that if the legislation was

\footnotetext{
${ }^{364}$ Fisher, "Balancing Rangatiratanga and Kawanatanga: Waikato-Tainui and Ngāi Tahu's Treaty Settlement Negotiations with the Crown," 123. Fisher cites references from both the Te Rūnanga o Ngāi Tahu, and the Waikato-Tainui archives to support these assertions. These archives are not publically available. I have been unable to locate any other references to this hui.

${ }^{365}$ Sir Douglas Graham does not have any recollection of this meeting; Personal Communication with Sir Douglas Graham, 28 July 2015

${ }^{366}$ Fisher, "Balancing Rangatiratanga and Kawanatanga: Waikato-Tainui and Ngāi Tahu's Treaty Settlement Negotiations with the Crown," 123.

36720 April 1994, 'Graham fails to allay fears of Treaty deal', The Evening Post

${ }^{368} 27$ April 1994, CSC (94) 43, 'Treaty of Waitangi Settlement Fund' approved by Cabinet 2 May 1994, CAB (94) M15/7 Yellow Book,
} 
passed with only a small majority, it could undermine its credibility and authority in the minds of the general public. ${ }^{369}$ Given the small majority that National maintained in Parliament this seems to have been a real concern for the government at the time. Ruth Richardson, as Minister of Finance had been a keen supporter of legislation to control the settlement fund, but she had now been replaced by Bill Birch who did not appear to be as committed to that approach. While Treasury expressed a preference that the settlement fund should be legislated, it noted that Graham and his advisors at TOWPU favoured the settlement fund being implemented through policy alone. Treasury advised that if the settlement fund was to be implemented this way it needed to be clearly defined firstly by an up-front dollar figure on the amount available to settle historical claims, and secondly, 'by settling a large claim and then relying on relativities between claims to give an implicit limit. ${ }^{370}$ Graham was able to convince his Cabinet colleagues of his reading of the situation and at its meeting on 2 May 1994 Cabinet reversed its earlier decision and agreed that the Treaty of Waitangi Settlement Fund would be implemented by government policy alone. ${ }^{371}$ As this example demonstrates, the development of the Treaty claims settlement process is essentially a political one.

Once Cabinet decided that the settlement fund was going to operate on a policy basis, officials were asked to consider some of the finer details or technicalities on how the fund would be managed and contained. ${ }^{372}$ The next Cabinet paper on the details of the settlement envelope in June 1994 reiterated earlier decisions about the costs that would be deducted from the fund (this was months before Cabinet agreed to the total of the fund). ${ }^{373}$ TOWPU and Treasury began referring to the need to establish some sort of comparison or relativity between claims to act as a 'control' on the overall cap and internal discussion began to focus on how the relativities between claims should be determined.

\footnotetext{
${ }^{369} 5$ May 1994, CAB (94) M 15/7, 'Treaty of Waitangi Settlement Fund', para 14 v, Yellow Book 37015 April 1994, 'Briefing Minister of Finance on Settlement Fund', Treasury Papers.

${ }^{371} 5$ May 1994, 'Treaty of Waitangi Settlement Fund', CAB (94) M 15/7, Yellow Book.

${ }^{372}$ From this time on the settlement fund was referred to as the settlement envelope in official documents

${ }^{373}$ Although as noted there are some references to the amount of $\$ 1$ billion being referred to prior to the final Cabinet decision in November 1994.
} 
In the meantime, the number of claims registered with the Waitangi Tribunal continued to grow. In 1990 there had been 90 claims registered; by the end of 1993 that number had increased to $423 .{ }^{374}$ There was some concern among Crown officials, and others in the Treaty sector that the settlement envelope would run out before all historical claims had even been registered, let alone fully investigated and understood. Claims relating to land acquired under the public works Act, and the impact of the Native Land Court and related Native Land laws, for example, had not been comprehensively assessed at all by this time. An influential historian associated with the Waitangi Tribunal, Emeritus Professor Alan Ward, urged for less haste in the process of settling claims. Ward argued that there was not yet sufficient research or knowledge about the extent of historical claims in all regions and that the government was 'rushing' the process. ${ }^{375} \mathrm{He}$ was concerned that a fixed amount of money was being set aside to settle all claims and yet the full range of experiences that had led to those claims was still not known. Rather than an 'acre by acre' assessment of Crown action, Ward advocated for a broad approach, highlighting key policies and impacts nationally and regionally. ${ }^{376}$ Graham and his officials at TOWPU had already been exploring a regional approach to claims by this time, as a way of streamlining processes that might otherwise get bogged down in multiple negotiations with small groupings within those regions. After broad-brush research findings settlements could be forged at iwi level. ${ }^{377}$

The Waitangi Tribunal adopted a regional research approach as well, leading to the Rangahaua Whanui national overview project, commissioned in 1993. Led by Ward, the intention of the project was to provide some broad context to historical action and policy of the Crown, which would help streamline the lengthy research and inquiry process of the Waitangi Tribunal and alleviate concerns that the process in place was unfairly advantaging claims 'first dealt with in the long claimant queue. ${ }^{378}$ Certainly, Edward Durie, Chairman of the Waitangi Tribunal and Alan Ward were

\footnotetext{
${ }^{374}$ Te Manutukutuku Waitangi Tribunal Division Department of Justice Newsletter, no.27, March 1993 ${ }^{375}$ Alan Ward, "Less Haste Urged for Resolving Treaty Claims," The Dominion, 20 January 1994.

${ }^{376} 3$ February 1993, Graham meeting with Alan Ward (Chief Historian at Crown Congress Joint Working Party), TS 37 , OTS archive

${ }^{377}$ Interview with former TOWPU official 2, 25 September 2012

378 Te Manutukutuku Waitangi Tribunal Division Department of Justice Newsletter, no.24/25, OctoberDecember 1994 4; Alan Ward, "National Overview Waitangi Tribunal Rangahaua Whānui Series, 3 Vols," (Wellington: Waitangi Tribunal, 1997).
} 
concerned with the concept of a limited settlement fund being imposed before sufficient research on the background to claims had been undertaken, potentially creating a situation where insufficient resources remained for significant, yet less recognised Crown breaches of the Treaty. Michael Belgrave suggests that the three volumes of the Rangahaua Whanui National Overview Report provided 'some assistance to government in 'comparative compensation'. ${ }^{379}$ While the Overview Report influenced the Waitangi Tribunal's approach to hearings with the adoption of a new casebook method, however, the extent to which they were utilised by government as a guide for relativities is doubtful, particularly given that the WaikatoTainui Deed of Settlement and the Ngāi Tahu heads of Agreement had been signed by the time the Overview Report was released. ${ }^{380}$

Officials meanwhile had advised government that to regulate and contain the settlement envelope a clear sense of 'ranking' of claims would be needed from the beginning. It was suggested that the status of claims could be determined by several factors including the amount of land and resources lost, the nature of the grievance (for example military invasion and raupatu was regarded as more serious than adverse results of incompetent officials), the needs of the claimants, and the size of the claimant group. Based on analysis at the time TOWPU officials regarded the raupatu-based claims of Tainui and Taranaki at the upper level. ${ }^{381}$ Recent discussions on the 'relativity clauses' included in the Waikato-Tainui and Ngāi Tahu deeds of settlement have tended to portray these as unduly advantaging those iwi. But the government needed to establish a comparative ranking of claims soon after the introduction of the settlement envelope, and the selection of the major raupatu iwi, and Ngāi Tahu, the major South Island iwi which had suffered huge land loss, reflected an assessment of the impact of bloodshed and resource loss that was based on historical analysis as well as on procedural Crown dealings with those groups.

\footnotetext{
${ }^{379}$ Michael Belgrave, "Something Borrowed, Something New: History and the Waitangi Tribunal," in Going Public: The Changing Face of New Zealand Hitsory., ed. Bronwyn Dalley and Jock Phillips (Auckland: Auckland University Press, 2001), 106.

380 Te Manutukutuku Waitangi Tribunal Division Department of Justice Newsletter, no.41 June-July 1997; Orange, The Treaty of Waitangi, 260.

${ }^{381} 28$ April 1994, Internal TOWPU Memo, T 5/2 5, OTS archive. The Ngāi Tahu claim was not mentioned in this memo
} 
Some ministers were uneasy that aspects of the settlement envelope may have been at risk to judicial challenge, in particular aspects of pre-determination and relativities. Officials reiterated that if claimants considered the settlements on offer were fair and just the process would be successful. They advised that if the comparisons between claims were approached in an overly mechanical or overt way, that could provide the basis for claimants to have the settlement fund judicially reviewed. ${ }^{382}$ Rather, officials reminded ministers, 'relativities within the Envelope must be seen as politically determined' on the basis of the recognition of historical grievances. $^{383}$ It was also noted in this paper, that claimants would have some sense of the relativities of their own claims within the Treaty settlement cap. Neither did the Waitangi Tribunal inquiry make comparisons between claims.

\section{Major Policy Developments}

Cabinet had previously agreed that all costs of settling historical claims since 21 September 1992, apart from the Crown's negotiating costs, would be offset against the envelope. ${ }^{384}$ Those costs, somewhat controversially, included the approximately $\$ 170$ million for the fisheries settlement which had been signed on 23 September 1992, just after the decision to create the fund had been made. Certainly TOWPU were advising Graham that the fisheries settlement should not be taken out of this fund, or if it was, the amount of the fund should be increased to accommodate this. ${ }^{385}$ This decision and the proximity of those two events caused some frustration later, as most of those signing the fisheries agreement had no knowledge of the establishment of the envelope, and later felt resentful that the compensation was being deducted from a finite fund they knew nothing about.

\footnotetext{
38220 June 1994, CSC (94) 73, Detailed Definition and Implementation of Treaty of Waitangi Settlement Envelope, T 5/2 5, OTS archive. In the version released in 1995, this section had been deleted. see 20 June 1994, CSC (94) 73, Report of Ad hoc Officials Committee to Cabinet Strategy Committee, Yellow Book

38320 June 1994, Report of Ad hoc Officials Committee to Cabinet Strategy Committee, T 5/2 5, OTS archive. A further Memo in September referred to a meeting 26 September 1994 on legal risks on pre-determination/relativities, interoffice memo, T 5/2 vol 5

${ }^{384} 5$ July 1993, 'Treaty of Waitangi Claim Settlement Fund: Size, Shape, Timescale and the Reciprocation from Maori', CAB (93) M 24/13 (e), Yellow Book

${ }^{385}$ Interview with former Crown official 2, 25 September 2012
} 
All the costs of land transferred back to claimants, (including land held in land-banks and wāhi tapu sites), any holding costs and current market value of those assets was to be deducted from the settlement envelope. Along with any claimants' research costs that had been funded by the Crown and negotiating and technical costs as reimbursed by the Crown. Compensation to claimants under the Crown Forest Assets Act 1989, and any resumption under the Treaty of Waitangi (State Enterprises) Act 1988 made by the Waitangi Tribunal were also to be deducted from the settlement envelope. These details were reconfirmed by Cabinet in June $1994 .^{386}$

By June 1994, Cabinet was considering how to present the settlement envelope in the annual Crown accounts, and which Crown assets should be available to be returned as part of compensation for a settlement. ${ }^{387}$ Another important issue related to this was how Treaty claims relating to natural resources should be taken into account in a settlement. In 1993 officials had advised that lack of policy on claims to natural resources, which included fresh water, geothermal energy, river and lake beds, foreshore and seabed, sand, shingle and minerals (including gold, coal, gas and petroleum), was hampering the settlement of claims. ${ }^{388}$ Both WaikatoTainui and Ngāi Tahu had considerable claims to natural resources. Waikato-Tainui had recognised interests in natural resources such as the Waikato River, harbours and coal within its rohe. ${ }^{389} \mathrm{Ngāi}$ Tahu had proven substantial interests in pounamu, mahinga kai and other significant natural resources, many of which were by the late twentieth century part of the Department of Conservation estate. ${ }^{390}$ Māori considered these natural resources taonga, guaranteed to them under Article II of the Treaty and confirmed through customary use and access. As Alan Ward

\footnotetext{
${ }^{386} 27$ June 1994, 'Detailed Definition and Implementation of the Treaty of Waitangi Settlement Envelope', CAB (94) M 23/20, Yellow Book

38727 June 1994, 'Detailed Definition and the Implementation of the Treaty of Waitangi Settlement Envelope', CAB (94) M 23/20 Yellow Book, 27 June 1994; CAB (94) 24/9 'Consultation with Maori and the Wider Public on Treaty of Waitangi Settlement Policies'

38819 July 1993, CSC (93) 122, 'Overarching policy on Treaty claims affecting natural resources', Yellow Book. This thesis does not consider the details of the foreshore and seabed debate, which resulted in the Foreshore and Seabed Act 2004

${ }^{389}$ The claims to the harbours and rivers were deferred during the process of negotiations, Fisher, "Balancing Rangatiratanga and Kawanatanga: Waikato-Tainui and Ngāi Tahu's Treaty Settlement Negotiations with the Crown," 127.

390 Tribunal, The Ngai Tahu Report 1991 (Wai 27), chapter 17.
} 
explained, traditionally Māori had not separated the waters and the river, nor the fish or waterfowl they supported:

A hapu or several hapu would control a certain territory, and the mana of the chiefs of that community would lie over that territory. For Maori this was tantamount to ownership of the waters as well as the land.' ${ }^{391}$

From the mid-nineteenth century, Māori had objected to the Crown's assumed ownership of lakes and navigable rivers, and to legislation that had eroded access to and control of natural resources such as waterways and geothermal resources. Māori had maintained ongoing links and associations with areas of natural resource, and had a clear expectation that such natural resources would be included as part of a Treaty settlement.

Much public, Crown and legal discussion focussed on the ownership and use of resources at 1840; for example pounamu was used and recognised at 1840, whereas radio airwaves were not. ${ }^{392}$ The Waitangi Tribunal differentiated between 'taonga tuku iho no nga tupuna' (taonga handed down from ancestors), which existed in 1840, such as te reo Māori and potential not realised in 1840, such as radio 'airwaves'. In relation to the radio spectrum, the Tribunal recognised a 'hierarchy of interests in natural resources based on the twin concepts of kawanatanga and tino rangatiratanga', or Article One and Article Two of the Treaty. ${ }^{393}$ It did not uphold the claim to the airwaves. But Ngāi Tahu rights to pounamu were considered differently as the value and potential of pounamu had been identified and utilised by Ngāi Tahu prior to 1840 and the Tribunal therefore recommended that all pounamu on Crown land be vested in the iwi, and all pounamu mining rights should be granted solely to Ngāi Tahu, including pounamu on private land. ${ }^{394}$ Officials and Cabinet debated the approach taken by the Tribunal and the extent to which the natural resources policy might reflect this approach. The official papers on natural resources referred to the need to recognise the expectations of Māori claimants, but also pointed out that the Crown had a right to

\footnotetext{
${ }^{391}$ Ward, An Unsettled History: Treaty Claims in New Zealand Today, 52.

392 The Waitangi Tribunal had reported on two claims to the radio spectrum, see Waitangi Tribunal, Report of the Waitangi Tribunal Claims Concerning the Allocation of Radio Frequencies (Wai 26, Wai 150) (Wellington: Waitangi Tribunal, 1990).

${ }^{393}$ Waitangi Tribunal, Report of the Waitangi Tribunal Claims Concerning the Allocation of Radio Frequencies 42.

${ }^{394}$ Tribunal, The Ngai Tahu Report 1991 (Wai 27), vol.4, 715-27.
} 
assert its sovereignty through the legislative process. ${ }^{395}$ As a reminder of the political nature of this process, officials emphasised the importance of giving assurance to the general public that common interests in natural resources would be maintained. In other words the Crown's rights and powers under Article One of the Treaty were considered sufficient to over-ride Māori Article Two interests in natural resources, where this was considered to be in the interests of all New Zealanders. This is a further example of the complexity of these issues; balancing Māori rights of rangatiratanga and the Crown's right to govern. Cabinet agreed that the form and level of redress should be guided by affordability (as with all policy development during this period), and that redress was to address the overall grievance without interfering with existing property rights. In the end Cabinet decided that the Crown would:

not negotiate Treaty claims based on acceptance of Maori ownership interests in natural resources, on the understanding that an ownership interest would extend to and include (as in fee simple) all the unknown potential uses of those resources at $1840 .{ }^{396}$

The Crown would not, then, automatically recognise a claim if the claimants could demonstrate rights to a resource as at 1840: it was also necessary for claimants to demonstrate a well-founded grievance in relation to it.

Further Cabinet decided that there were occasions when it was necessary for the Crown to own or regulate resources in the interests of all New Zealanders; and this right would over-ride the interests of Māori owners. ${ }^{397}$ This included, in particular, resources held within the Conservation Estate. As a compromise, redress to these areas could also take the form of increasing the level of Māori participation on regulatory bodies. Cabinet noted that Māori might have a different view from that of the Crown on the nature of their interests in natural resources, and that the Crown would take the opportunity to avail itself of the views of claimants through the upcoming consultation process and through individual negotiations. Indeed, the policies relating to natural resources came under intense scrutiny when the draft

\footnotetext{
${ }^{395} 22$ July 1993, 'Overarching Policy on Treaty Claims Affecting Natural resources', CSC (93) 132, para 9.5 onward

39623 March 1994, 'Crown Policy on Treaty of Waitangi Claims to Natural Resources', CAB (94) M $9 / 6$

39723 March 1994, 'Crown Policy on Treaty of Waitangi Claims to Natural Resources', CAB (94) M 9/6, para d, see also Justice, "Principles for Crown Action on the Treaty of Waitangi."
} 
policies were released in December 1994. Māori felt there was little acknowledgement of the historical events that had enabled land to be in the Department of Conservation's jurisdiction in the first place. Māori also felt their position of kaitiaki or custodian of the environment was being undermined; this particularly came to the fore during the course of the Ngāi Tahu negotiations. ${ }^{398}$ Many conservationists, including Department of Conservation staff were concerned that Māori might not be able to co-manage conservation areas appropriately. The fact that Cabinet agreed with this sentiment is a demonstration of the power of both the Department of Conservation and the organised conservation interest groups outside of government at this time. ${ }^{399}$

\section{Seeking Certainty}

The government was determined that any negotiated settlements were to be comprehensive, full and final; to that end draft policies were formulated on establishing a clear process of mandate and on settling all claims of each claimant group for once and all. Officials therefore set about developing an approach that would provide certainty about which claims were being settled, and ensuring that a claimant group had direct links to the historical claims that were being negotiated. Further, those representatives involved in the actual negotiations with the Crown needed to be endorsed by those claimants. Addressing matters of claimant representation were part of the development of a robust mandating process. As well as developing a process for achieving a mandate, officials were developing procedures for ensuring that a claimant group would agree to negotiate a final settlement of all its claims (even claims that may not have been registered with the Waitangi Tribunal by this time). ${ }^{400}$ This process was officially referred to as the 'quid pro quo' ('this for that'); in exchange for compensation, the settlements were to be full and final, to give the general public reassurance that these issues would not be revisited.

\footnotetext{
${ }^{398}$ Martin Fisher, "Defenders of the Environment: Third-Party Interests and Crown-Ngāi Tahu Treaty Settlement Negotiations," Treaty Research Series (2015).

39924 June 1994, Hon D. Graham, Minister of Justice, Address to a Public Meeting Organised by Public Access

400 Unless specifically exempted by Cabinet, 22 August 1994, 'Revised Treaty Negotiations Process', CAB (94) M 31/15, para d i, Yellow Book
} 
Issues of claimant representation and mandate had first been addressed by TOWPU in 1990 when it developed its policies for direct negotiations, published in The Direct Negotiation of Māori Claims: An Information Booklet. ${ }^{401}$ The booklet identified criteria for the acceptance of a claim for direct negotiation, including whether the claimants wished to negotiate all or part of the claim, and that the person acting on behalf of the claimants needed to properly represent the iwi, hapū and whānau concerned. ${ }^{402}$ With the advent of the settlement envelope, emphasis on containment, and the passing of the Runanga Iwi Act Repeal Act 1991, these previous criteria were tightened. From 1992, officials put an increased focus on negotiating with the 'right group'. No longer was the issue limited to who represented Māori in their interaction with the Crown, it was also expanded to take in what area of land a particular group was historically linked to, as allocation of assets (whether fisheries, forestry, or resources) became inextricably linked to mana whenua or territorial rights. Tracing the policy development that led to the release of the Crown Proposals in December 1994 provides some insight to official thinking of land issues at the time. For example, in June 1993 a Cabinet Committee paper noted that:

when it came to grievances relating to historical dispossession of land and land-based resources, the claims were tribal. For settlements to these claims to be effective in terms of progress from "grievance mode to development mode", the Crown would need to negotiate with individual tribes. ${ }^{403}$

Claimant representation problems were considered a potential 'risk' to the settlement fund. To mitigate this vulnerability, the Crown needed to ensure that it was dealing with both the appropriate claimants and the appropriate representatives of those claimants, and that further claims within the rohe were not lodged subsequently. Officials and ministers discussed these issues over the course of the next few months and concluded that it was necessary to ensure that mandate procedures were in place for each claim grouping: a claimant group, its negotiators and its membership all needed to be defined. By 1994 it was decided that a formal deed of mandate would be prerequisite to entering the formal process of negotiations, known

\footnotetext{
401 Issues, The Direct Negotiation of Maori Claims: An Information Booklet.

402 The Treaty of Waitangi Policy Unit for the Crown Task Force on Treaty of Waitangi Issues, The Direct Negotiation of Māori Claims: An Information Booklet, (September 1990), 8

40328 June 1993, 'Treaty of Waitangi Claim Settlement Fund: Size, shape, timescale and the reciprocation from Maori' CSC (93) M 27/1, Yellow Book
} 
as the Negotiations Work Programme (NWP). A deed of mandate required a definition of the claimant group together with the claims to be covered by the negotiations beneficiaries, (all the claims of that group whether they had been registered with the Waitangi Tribunal or not) and a definition of the boundaries covered by the negotiations. For the first time, all of the claims of a defined claimant group over its area were to be negotiated at the same time. The deed of mandate identified authorised negotiators to represent that claimant group in negotiations with the Crown. Another requirement introduced at this time was the need to establish a robust legal entity to receive and administer the assets received from a negotiated settlement. ${ }^{404}$ The government had previously agreed that it needed to ensure any settlement assets should be used for the benefit of claimants; it now rescinded that decision. ${ }^{405}$ Clearly government influence on how settlements were to be used was now seen as a step too far. The settlements were to be unencumbered, except that administration of the assets needed to be legally rigorous.

As a way of managing negotiations into the future, a controversial suggestion was made to amend the Waitangi Tribunal's statutory powers so that claims could only be lodged by iwi. ${ }^{406}$ The fact that 'any Māori' could register a claim with the Waitangi Tribunal was seen by the Crown as having the potential to disrupt government plans to settle claims at an iwi or tribal level and therefore efforts to contain costs. ${ }^{407}$ The idea gained traction and the proposal that the Treaty of Waitangi Act 1975 be amended so the Tribunal could only inquire into claims registered by a mandated iwi or hapū, was included as part of the Crown Proposals. ${ }^{408}$

The government was firm that negotiated settlements must achieve some sort of finality that could be agreed upon between Crown and claimants. In 1989 and 1990 TOWPU officials had proposed that the Crown seek settlements that would be 'durable', rather than a requirement that they be 'full and final'. This way, officials

\footnotetext{
${ }^{404} 21$ March 1994, CAB (94) M 9/8, Yellow Book

40521 September 1992, CAB (92) M 38/11; 17 October 1994, CAB (94) M 39/11 (i,j), Yellow Book 40612 July 1993, File Note: 'managing the risks', From TOWPU to Officials from Treasury, DPMC \& TOWPU

${ }^{407}$ The Crown now seeks to negotiate and settle with large natural groupings, Settlements, Ka Tika $\bar{A}$ Muri, Ka Tika Ā Mua: Healing the Past, Building a Future. A Guide to Treaty of Waitangi Claims and Negotiations with the Crown, 39.

${ }^{408}$ Settlements, Crown Proposals for the Settlement of Treaty of Waitangi Claims: Detailed

Proposals, 37. This proposal was later dropped
} 
argued, if a settlement was adequate and just it would stand the test of time without needing to declare itself 'full and final'. This approach was set out again in the September 1992 Cabinet paper, which was the first attempt at establishing the 'principles and parameters' of a settlement process. ${ }^{409}$ In part this was a response to the awareness of and sensitivity to the agreements of the 1940s and 1950s, which had sought to be 'full and final' and yet had proved not to be. ${ }^{410}$ Over time this idea of durability was eroded and replaced again with the term 'full and final'. As part of the drive to control spending on Treaty settlements and remain within the settlement envelope (remembering that the quantity of that envelope had not been defined at this time) government sought to ensure that negotiations were final.

A further prerequisite to entering the formal process of negotiation or the Negotiations Work Programme was that claimants had to agree to a full and final settlement of all of their claims. What was being called for was that claimants would agree a Deed of Settlement would specify that all of the historic claims of the defined claimant group would be settled - including claims that had not yet been investigated, or known at this time. Claimants were also going to be asked to agree that any memorials over their land (under the State-owned Enterprise or any relevant legislation) would be removed. ${ }^{411}$ It was proposed that these details would then be enacted in individual legislation at the conclusion of a settlement. It was planned that these strategies would be released as part of the consultation document.

\section{The Size of the Settlement Envelope}

Discussions on how to manage the settlement envelope were kept separate from discussions on how much money it would contain. The size of the envelope was always regarded as a matter of political judgment, and not a matter for official advice (at least not written advice). The first mention of a dollar amount which might be

\footnotetext{
${ }^{409} 21$ September 1992, 'Principles for Settlement of Maori Claims', CAB(92) M38/11, Yellow Book

${ }^{410}$ For explanation of this term see Marr, "Crown Policy Towards Major Crown-Iwi Claim Agreements of the 1940s and 1950s: A Preliminary Report for the Treaty of Waitangi Policy Unit."

41110 October 1994, Cab (94) M38/7, Yellow Book, final issues dealt with in 17 October 1994, Cab (94) 39/11, Yellow Book
} 
spent on settlements was in August 1992. There was a recommendation in a Cabinet paper to pay $\$ 100$ million a year for ten years, $1992 / 93$ to $2001 / 2$, inclusive, 'into a trust fund to be established by the Crown', which would meet the cost of all claims 'other than taonga and environmental claims'. ${ }^{412}$ It is a little surprising to see that the $\$ 1$ billion amount had been referred to as early as August 1992. There did not appear to be any ongoing references to this paper or this amount of money indicated in it, in later papers on the fiscal envelope. It is not clear which claims were considered 'taonga and environmental claims' in this context, but it is likely that this was what was later referred to as 'cultural redress'. Neither was there any reference to the fisheries settlement being deducted from a settlement fund. This does suggest that there had been an informal discussion at Cabinet (or between ministers) on the appropriate amount.

According to Graham, Cabinet's decision on the quantum amount was made at the last minute as the consultation booklets were being prepared for release. ${ }^{413}$ This is consistent with the Cabinet papers I have been able to access. For example on 1 November 1994 a paper on the preparation of the consultation process and the publication of the booklets noted that the 'final agreed quantum and the period over which the quantum will be expended are yet to be agreed. ${ }^{\prime 414}$ Cabinet made the final decision on the amount of the envelope, or the quantum on 7 November 1994. There was an accompanying memo by Graham for Cabinet setting out the previous decisions made on the Settlement Envelope to that point, but it did not make a recommendation on a dollar amount. Cabinet ministers were briefed orally by officials, but the advised amounts varied a great deal. Cabinet made three key decisions that day. It agreed that the overall quantum was to be $\$ 1$ billion in September 1992-dollar terms. It also agreed that the first charge on the envelope was to be all costs incurred since September 1992 connected with the settlement of historical claims, including the $\$ 170$ million for the fisheries settlement, and $\$ 15$

\footnotetext{
41212 August 1992, Memorandum for Cabinet Strategy Committee, 'Ten Year Programme of Settling Māori Treaty Claims', para AD, Yellow Book

${ }^{413}$ Douglas Graham, Introduction to 'Policy Papers for Crown Proposals for the settlement of Treaty of Waitangi Claims', released on 3 March 1995, yellow book.

414 November 1994, CSC (94) 152
} 
million for other settlements. ${ }^{415}$ Cabinet also noted that the quantum would be published in Treasury's December forecast (Economic and Fiscal Update) as a risk. ${ }^{416}$

Speculation on the amount of the settlement envelope had been circulating for months before the Cabinet decision of November 1994, but it is difficult to uncover exactly how or when the $\$ 1$ billion figure for the settlement envelope was decided on. Ranginui Walker reported in September 1994 that rumours were circulating that the 'outer limit of the envelope' was a billion dollars.' ${ }^{417}$ The following month Walker reported that the amount of the fiscal envelope had been disclosed on a television programme in May 1994, and that a pan-tribal organisation of Māori students had formed to challenge the concept. ${ }^{418}$ Martin Fisher records that, according to claimant documents he has seen, Graham had disclosed the concept and the amount of the fiscal envelope to a number of claimants at a hui in February 1994. ${ }^{419}$ Graham himself later recorded that the final decision on quantum had been made in September 1994, although this reference is also inconsistent with the November Cabinet decision. ${ }^{420}$

It would seem that any reference to the amount (or quantum) of the settlement envelope prior to the November 1994 Cabinet decision cannot be regarded as definitive. In an interview in 2012 Graham noted that Cabinet had met and discussed the fiscal envelope at length; 'the Treasury were very much heading for a low figure...my Ministry officials were trying to get as high as we could.' ${ }^{421}$ Graham could not recall the exact details of the amounts being argued and concluded; 'it doesn't really matter. At the end of the day I think probably the Prime Minister said I

\footnotetext{
415 These historical settlements were not listed in the Cabinet paper. Deeds of settlement for $1992-$ 1994 period appear to be Ngati Rangiteaorere (wai 32), Hauai (wai 200), Ngati Whakaue (wai 94), accessed 26 July 2012, https://www.ots.govt.nz/documents/deedsofsettlement

4167 November 1994, 'Settlement Envelope Quantum', CAB (94) M 43/6, Yellow Book; see also 21 November 1994, 'The Treaty Settlement Envelope: Budgeting and Reporting', CAB (94) M 45/21, Yellow Book. The paper sets out details of the budgeting and reporting of the settlement envelope. ${ }^{417}$ Walker, "Te Karanga: Pushing the Envelope," 144.

418 "Te Karanga: Tribal Lolly Scramble," Metro Magazine, October 1994. I have not been able to locate any further references to the Frontline programme

${ }^{419}$ Fisher, "Balancing Rangatiratanga and Kawanatanga: Waikato-Tainui and Ngāi Tahu's Treaty Settlement Negotiations with the Crown," 123.

${ }_{420}$ Graham, Trick or Treaty?, 60.

421 Interview with Sir Douglas Graham, 15 August 2012
} 
think the best solution to this is a billion dollars over ten years. ${ }^{422}$ Uncertainty about what the $\$ 1$ billion dollar quantum was based on continued to circulate after the Cabinet decision. On 7 December 1994 the lead article in The Dominion newspaper stated that 'Treasury officials had suggested $\$ 2.2$ billion was the minimum the Government would have to offer to be sure of majority Maori support.' ${ }^{423}$ Treasury denied offering such advice and noted;

in our view the credibility of the $\$ 1$ billion Settlement would be undermined if the public perception is that Treasury recommended a $\$ 2.2$ billion Settlement Envelope. We suggest that Ministers explicitly note when releasing the Crown Proposals on Settlement of Treaty of Waitangi Claims that Treasury did not make any such recommendation. ${ }^{424}$

A former TOWPU official recalled that TOWPU had recommended to its minister that the settlement envelope be set at around \$2.2 billion and Te Puni Kōkiri had recommended the slightly lower amount of \$2 billion, both excluding the 1992 fisheries settlement. ${ }^{425}$ Given the perspectives of the various government departments involved in this work, it would seem consistent that TOWPU and TPK officials were advising their ministers on a higher level of quantum. It would also seem consistent that Treasury would be supporting the lowest possible sum. not be supporting a higher amount. In the two years leading up to this decision Treasury's primary concern was to contain the costs of settlement, rather than ensuring that the majority of Māori supported the settlement envelope.

There were two main levels of Māori opposition to the settlement envelope. The first was the extent to which the policy had been developed in isolation from Māori, which as Alan Ward pointed out, was 'in stark contravention of any concept of partnership or obligation to consult, as had been espoused in the development of Treaty principles'. ${ }^{426}$ The second main level of opposition was frustration at the low amount of the quantum, particularly considering that the $\$ 1$ billion was to include compensation for the fisheries settlement and for all historical claims, including

\footnotetext{
422 ibid

4237 December 1994, 'Govt set to make Maori land deal', The Dominion

4247 December 1994, Treasury to Minister 'Treaty Settlement Envelope - Media Reports of \$2.2

Billion Treasury Advice', Treasury Papers

${ }^{425}$ Interview with former Crown official 2, 25 September 2012. I was unable to locate any documentation on this aspect in my research.

${ }^{426}$ Ward, An Unsettled History: Treaty Claims in New Zealand Today, 52.
} 
claims not yet even registered with the Waitangi Tribunal by 1994. Mason Durie echoed this frustration: 'the amount necessary to ensure a just settlement is not known. Estimates vary, but even highly conservative assessments suggest that the sum of one billion dollars falls well short of a reasonable and fair settlement price by some ten or more billion dollars. ${ }^{1427}$ A further point of frustration for Māori was that the settlement envelope concept and quantum were presented 'for information only' during the consultation process. This was seen as a provocation, and indeed the $\$ 1$ billion non-negotiable cap that dominated the process of consultation.

\section{Planning of Consultation Process and Release of the Crown Proposals}

Planning for consultation with Māori and the wider public on the Treaty of Waitangi settlement policies was led by Te Puni Kōkiri (TPK) and had been underway for almost two years before the December 1994 release of the Crown Proposals. ${ }^{428}$ In June 1994 the Ministry identified a programme of consultation and information on the policies as having three main objectives: to fulfil the Crown's moral and legal duties under the Treaty of Waitangi by consulting with Māori on major policy issues affecting them; to inform the general public of the Crown's position on settlement policies; and finally, to give 'a political and societal consensus on issues to do with the settlement of Treaty grievances. ${ }^{429}$ At this time, the plan was to consult with Māori (as Treaty partner) first, and subsequently inform the public on the outcome of the Crown-Māori consultation process. This two-tiered approach to consultation did not eventuate.

In the end the settlement envelope was presented 'for information only'. Cabinet agreed that the settlement envelope would not be consulted on, despite TPK and TOWPU officials advising against presenting the policies as a fait accompli. Those officials considered that the settlement envelope would 'have as significant an

\footnotetext{
${ }^{427}$ Durie, Te Māna, Te Kawanatanga: The Politics of Māori Self-Determination, 192.

428 For example 10 February 1993, Te Puni Kōkiri paper 'Treaty of Waitangi Settlement Fund Consultation Process'. The paper set out a proposed consultation strategy

${ }^{429} 27$ June 1994,'Coverage of Settlement Envelope', CSC (94) M 21/1, Yellow Book
} 
impact on Māori interests as those policies on natural resource and the conservation estate, and hence should be consulted on at a broad level. ${ }^{430}$ TPK noted that officials from the Department of Justice were the only other officials who supported this approach. ${ }^{431}$ This advice was not taken. The Crown Law Office had earlier advised that the Crown was not required to consult 'on the size of the settlement envelope. ${ }^{432}$

The Crown Law Office also advised that the Crown would be obliged to re-negotiate on policies relating to the Treaty of Waitangi (State Enterprises) Act 1988 and the Crown Forest Assets Act 1989, but the Crown was not legally required to consult on other policy decisions. It pointed out however that legal obligations aside, the Crown should consult to honour its Treaty duty. On the nature of the consultation process, Crown Law pointed out that the essence of consultation was to have an open mind as to the outcome. Consultation had to take place at a formative stage of policy development, to allow sufficient time for Māori to respond to the proposed policies, and there needed to be a willingness to alter a proposed approach in light of feedback from Māori. The Crown Law Office reminded the government of its duty: 'those being consulted are not simply to be informed of an impending decision informing is not consultation. ${ }^{433}$

On 4 July 1994 Cabinet made the decision to inform and consult with Māori and the wider public on the Crown's policy position on Treaty settlement issues at the same time. The consultation process was to commence with release of a document containing a clear statement of the Crown's position on generic Treaty settlement policies. ${ }^{434}$ The document would be a compilation of the government's approach to generic policies such as claims to natural resources, and the use of the Conservation Estate in settlements. Details of the process of negotiations, mandating and how the Crown planned to ensure equity and fairness between

\footnotetext{
${ }^{430} 28$ June 1994, 'Brief to Minister of Māori Affairs: Consultation with Māori and the Wider Public on the on Treaty of Waitangi Settlement Policies'

${ }^{431}$ Ibid

43227 June 1994, 'Consultation with Maori and the Wider Public on Treaty of Waitangi Settlement Policies', CSC (94) M 21/1 ${ }^{433}$ ibid

4344 July 1994, Treaty of Waitangi settlement policies: Consultation with Maori and the wider public, CAB (94) M 24/9
} 
claimants was also to be included. Feedback would be invited on these aspects. As discussed, the settlement envelope concept and size of the envelope was to be presented for information only. For Māori, as Treaty partner, the extent to which policy had been developed prior to consultation was a major factor in the outrage that surfaced following the release of the Crown Proposals. The vast majority of Māori claimants had not been privy to the significant amount of thinking; discussing and decision-making that had gone prior to the public release of the draft policies. Moreover, as will be demonstrated in the following chapter, an alleged willingness to change the draft policies was not borne out in practice.

TOWPU were given responsibility for producing and distributing the consultation document and coordinating written responses from Māori and non-Māori.

Management of the regional hui and the recording of oral submissions made at those gatherings were the responsibility of TPK. A four-week period was planned between the publication of the booklets and the first hui with Māori, 'in order to allow time for Maori to consult among themselves and form an initial view on the policies. ${ }^{1435}$ Cabinet agreed that the Government would hold 12 regional hui over eight weeks, culminating in a national hui. Meetings were also to be held to allow the wider public the opportunity to express their views. It was planned that ministers would be available to attend the hui and public meetings. The deadline for written submissions was planned to be a month after the hui and public meetings. An indicative timeframe of four to six months after the publication of the settlement policies was anticipated for Cabinet to make its final decisions on the policies. As will be discussed in the following chapter the consultation process and coordination of feedback took considerably longer than anticipated, and negotiations continued under the auspices of the draft policies until 1996.

Cabinet also agreed that individual negotiations could continue in tandem with the consultation process, and to maintain the integrity of the consultation process

43527 June 1994, 'Consultation with Maori and the Wider Public on Treaty of Waitangi Settlement Policies', CAB (94) M 21/1. The fast moving nature of this work is reflected in the fact that papers were presented to Cabinet Strategy Committee on three consecutive days 27-29 June 1994. Usually papers were only considered on a weekly basis. 
provided it did not lead to a pre-determined outcome of the policies. ${ }^{436}$ Formal negotiations Waikato-Tainui and Ngāi Tahu continued at this time. To some, this rendered the consultation process disingenuous. If the outcome of the process was not going to impact on negotiations then why consult at all. Although it should be noted that the negotiations were undertaken without prejudice to any end result. At the end of October 1994, Cabinet gave approval on the content and the text of the three Crown Proposals booklets to be published. Last minute details such as the amount of the settlement envelope had not been included at this time; a fortnight was required between Cabinet's final decisions and printing of the booklets. ${ }^{437}$

The Crown Proposals for the Settlement of Treaty of Waitangi Claims were publically released to Māori, the media, and the public simultaneously on 8 December 1994. On that day, the Prime Minister was scheduled to brief the Governor-General and the Chief Ombudsman. Meanwhile Graham and other ministers met with key nongovernment organisations, business leaders, academics and constitutional experts. Editors and political commentators were invited to attend a separate briefing. ${ }^{438}$ The Prime Minister hosted the official launch at Premier House for a group of 'influential New Zealanders', including key Māori figures, church leaders, politicians and senior Crown officials. Some of those key Māori who declined the invitation included paramount chief of Ngāti Tūwharetoa Sir Hepi Te Heu Heu, the Māori Queen Dame Te Atairangikaahu, senior Ngāti Whakaue leader Charles Bennett and Tipene O'Regan of Ngāi Tahu. At the launch David Caygill, Deputy Leader of the Opposition and Labour's spokesperson on Treaty issues, said Labour supported the policies in theory, but were wary about the fiscal envelope and the amount of money set aside for the cap. ${ }^{439}$ Labour had previously publically expressed concerns about National's policy direction. But Caygill, was critical that the envelope concept would divert attention away from the justice of individual claims, to comparisons about the

\footnotetext{
${ }^{436} 27$ June 1994, 'Consultation with Maori and the Wider Public on Treaty of Waitangi Settlement Policies', CAB (94) M 21/1. This had been a point of dispute between TOWPU who were keen to see momentum of consultation continue and Treasury who considered that the consultation process should be considered before negotiations recommenced

${ }_{437} 31$ October 1994, 'Booklets for the consultation process on the Crown's proposals for settlement of the Treaty of Waitangi claims', CAB (94) $43 / 5$.

${ }^{438} 21$ November 1994, CAB (94) M 45/8

${ }^{439}$ Wira Gardiner, Return to Sender: What Really Happened at the Fiscal Envelope Hui (Auckland: Reed Publishing (NZ) Ltd, 1996), 32.
} 
size of the envelope. Both he and former Prime Minister David Lange were concerned that the small size of the envelope would set one group of claimants against another. ${ }^{440}$

The Crown Proposals were presented in three booklets published by the Office of Treaty Settlements, setting out the detailed proposals, the timetable of the consultation with Māori, and a summary booklet. The Summary booklet, published in Māori and English, presented a background to historical claims and the proposed process for negotiation and settlement of claims. It contained an introduction by Graham. The third booklet Consultation with Māori, included a foreword by Luxton, Minister of Māori Affairs, and detail of the timetable of regional hui, as well as information on how to make a submission at one of those hui. The Detailed Proposals booklet was aimed at those preparing a written submission. The tone of the written material in booklets was rather formal and stiff, potentially making it a challenge for the general public to understand. They tended to reflect the language and tone of Cabinet papers, rather than being presented in everyday language. Those drafting the material for publication were focussed on accurately presenting the decisions of Cabinet, but did not give sufficient attention to the fact that many readers would be encountering these concepts and this material would be doing so for the first time. Graham later reflected that the document was 'probably too Treasury-led' in its wording. ${ }^{441}$ Fifteen thousand copies of each of the booklets were printed for distribution to Māori while a further 15,000 of the 'Summary' and 'Details' booklets were distributed to non-government organisations, interest groups and the wider public. ${ }^{442}$

The release of the Crown Proposals provided the first opportunity for Māori to see the detail of how the government was going to approach direct negotiations, since the development of the new policy process over the previous 3 years. The

\footnotetext{
${ }^{440}$ David Lange, 'An appearance of progress' 31 January 1994, The Dominion; 'Settling Treaty claim limits', 15 July 1994, The Dominion. See also 30 September 1994, Aide Memoire: proposed multiparty accord on the Treaty settlement envelope issues, TOWPU Papers

${ }^{441} 28$ March 1995, 'Graham tries dignified pullback from Fiscal Envelope', The Dominion

442 Settlements, Crown Proposals for the Settlement of Treaty of Waitangi Claims: Detailed Proposals.; Crown Proposals for the Settlement of Treaty of Waitangi Claims: Summary.; Department of Justice Office of Treaty Settlements, Crown Proposals for the Settlement of Treaty of Waitangi Claims: Consultation with Maori (Office of Treaty Settlements, 1994).
} 
immediate focus for Māori (and for the media) was on the \$1 billion settlement envelope and how it was going to operate. ${ }^{443}$ The details of what was to be deducted from the settlement envelope were set out in the Summary and Detailed Proposals booklets. It was proposed that all the claimant costs of negotiations and the costs of settlements since 21 September 1992 were to be deducted including any land and resources for each claim and the holding costs of land held in landbanks. It was also proposed that the full cost of returning any wāhi tapu sites to claimants was to be deducted from the envelope as well as any compensation, including compensation under the Crown Forest Assets Act 1989, and resumptions under the Treaty of Waitangi (State Enterprises) Act 1988. Māori were surprised, and outraged, to learn that any claimant research, negotiating or technical costs reimbursed by the Crown since 21 September 1992 were to come out of the envelope, as was the cost of the Māori fisheries settlement of approximately $\$ 170$ million. ${ }^{444}$ Despite the fact that the Settlement Envelope was presented 'for information only' it came to dominate the discussion around the Crown Proposals.

Māori reaction to the policy proposals was strong and swift. Although the proposals were presented as drafts, to be finalised after consultation, many felt there was an air of inevitability about them. Māori dismissed the amount of money set aside to settle all claims as highly inadequate, and were disappointed that the Crown had acted unilaterally to draft policies. Some Pākehā were concerned that the amount of money being set aside was excessive in a time of economic recession.

Conservationists, particularly groups such as Forest and Bird and Federated Mountain Clubs of New Zealand, were concerned about the potential return of parts of the Conservation Estate as part of the settlement process. It had been planned that ministers would continue with 'quiet diplomacy' by meeting with Māori, nongovernment organisations, business leaders, constitutional experts and academics between December 1994 and April 1995. However, the reality was that reaction to the Crown Proposals was so intense that there was very little opportunity for a 'quiet' approach.

\footnotetext{
${ }^{443}$ The settlement envelope tended to be referred to as the fiscal envelope

444 Settlements, Crown Proposals for the Settlement of Treaty of Waitangi Claims: Detailed

Proposals, 9-12. Crown Proposals for the Settlement of Treaty of Waitangi Claims: Summary, 24-7.
} 


\section{Waikato-Tainui: Heads of Agreement}

Progress was being made with the Waikato-Tainui negotiations at the same time the Crown Proposals were being finalised. ${ }^{445}$ A file note from early October 1994 revealed the tensions between the dual process of the proposals and the Tainui settlement. The minister wanted to discuss a proposed timetable relating to both the completion of the Crown Proposals booklet and the Tainui settlement. At this time, it was envisaged that the release of the booklet and the announcement of the Tainui settlement could coincide on 12 December 1994. The minister was anxious that both processes should progress in tandem and 'be kept synchronised'. ${ }^{446}$ In the event, a Heads of Agreement was not signed between Waikato-Tainui and the Crown until 22 December 1994. At that time, too, Waikato-Tainui negotiators were at pains to point out they supported neither the Crown Proposals, nor the settlement envelope, although this point was later glossed over by both Graham and Bolger when they indicated that that Waikato-Tainui's signing of the Heads of Agreement gave support to the proposals. Bolger later emphasised the 'extraordinarily important decision made by the largest tribal confederation in New Zealand', Tainui, to resolve its claims, which were the largest in the country, 'under the government's broad package of proposals. ${ }^{447}$

\section{Chapter conclusion}

The year 1994 was a highly significant one for Treaty of Waitangi settlement issues. The second term of the Bolger-led National government changed the direction of Treaty settlements in New Zealand forever. From the time of the 1993 general election Treaty of Waitangi settlement issues took an unparalleled priority in New Zealand society. The government was working towards a collection of proposed policies that were eventually launched in December 1994, policies which were developed through the rigours of debate within officialdom and the cabinet committee process. It was clear that there were tensions, at times, between the

\footnotetext{
445 See Treasury memo 17 December 1994, Treasury Papers

4464 October 1994, OTS File note, TC 30, OTS archive

44730 January 1995, 'Hui Rejects Fiscal Envelope', 2YA Morning Report Transcript.
} 
willingness of Graham (as Minister of Justice) to forge ahead and make deals, and the government's focus on affordability and containment of the process. The progress made by Graham and like-minded ministers, supported by advice from their officials to get dedicated funding for Treaty settlements should not be underestimated, given that the early 1990s was a period of economic downturn and relatively high unemployment; and as Graham recalled, it was a bold move to ask for a substantial sum for Treaty settlements as well as for a new national museum. ${ }^{448}$

The government would argue that much of the development of Treaty settlement policy needed to happen behind the scenes, within the bureaucratic process. For Māori, it felt like history repeating itself, with the Treaty partner acting unilaterally to develop policy that was in effect, already determined by the time it was released. On a more positive note, as Alan Ward has noted, the proposals signalled significant and welcome policy shifts over and above the settlement envelope. They included an acknowledgment that historical injustices had occurred and that the Crown recognised that it had a duty to make reparations that were fair and sustainable, and 'accepted that the resolution of claims must be consistent and equitable between groups. ${ }^{449}$

However, the combined announcement of the settlement cap (which was not open for discussion) and the draft policies (which were theoretically open for discussion) caused a stalemate between Māori and the government. Māori had been continuing to call for a more open and authentic dialogue with the Crown, and now felt that there was only a token opportunity for their voices to be heard on policy issues, something which tended to be lost amidst the highly vocal reaction to the limited size and unilateral imposition of the settlement envelope. When discussing the reaction to the Crown Proposals Edward Durie, Chair of the Waitangi Tribunal said: 'we may find that the issue is not in fact mainly about money but primarily about how we manage race relations in the years ahead. ${ }^{450}$

\footnotetext{
${ }^{448}$ Interview with Sir Douglas Graham, 15 August 2012

${ }^{449}$ Ward, An Unsettled History: Treaty Claims in New Zealand Today, 52.

${ }^{450}$ E. Taihakurei Durie, "Welcome," in Treaty Settlements: The Unfinished Business, ed. Geoff McLay (Wellington: NZ Institute of Advanced Legal Studies and Victoria University of Wellington Law Review, 1995), 5.
} 
The summer of 1994-1995 proved a tense one, as the policy proposals released before Christmas sparked protest and occupations of sites of Crown land from Māori protest groups. The series of hui and community meetings around the country, beginning in February 1995, were to prove a testing experience for Māori hosts, politicians and the Te Puni Kōkiri bureaucrats who were in charge of coordinating and managing the hui. The Crown Law Office, which had provided advice on the consultation of the proposed policies, stressed that for consultation to be successful and ethical it needed to be genuine, with a willingness to change tack. The following chapter considers the process of consultation and the extent to which the consultation and submission process had any impact on the policies released as proposals in December 1995. 


\section{CHAPTER FIVE: AFTER THE ENVELOPE: REACTION TO THE CROWN PROPOSALS}

The Crown Proposals had been released by Treaty of Waitangi Policy Unit in December 1994. After announcing the need for a comprehensive approach to Treaty settlements and working in isolation for a number of years on developing a set of draft policies, which were released to the public for consultation. Prior to the launch of the Crown Proposals there had been ongoing references including in the mainstream media, to their development. ${ }^{451}$ The non-negotiable settlement envelope with its $\$ 1$ billion cap was announced along with the policies released for consultation. This simultaneous announcement of policies open for consultation and the settlement envelope which was not open for consultation was a public relations disaster for the government. The reaction from Māori was immediate and challenging.

The release of the Crown Proposals was followed by a series of hui and community meetings, attended by ministers and Crown officials, planned to present the proposals in detail to Māori and to interest groups. Oral submissions could be made at the hui and these were to be recorded. Written submissions would also be invited, analysed and considered. This chapter examines the details of the regional consultation hui and the submissions received in the first six months of 1995.

Māori felt that as Treaty partner, they should have been included in the development of the policies at an earlier stage. Graham was firmly of the view that it was the government's prerogative to develop a clear and consistent approach to these issues before going public with them. He also argued that the government were not acting in isolation, and had a good idea of what Māori were wanting as a result of being actively engaged in negotiations at the time. ${ }^{452}$ If this is accepted, perhaps the more significant aspect to consider then is the extent to which the consultation

\footnotetext{
451 The first example I have been able to locate is 19 May 1992, 'Govt Looks Ahead on Treaty Claims', New Zealand Herald. See also Douglas Graham 12 January 1994, 'Maori grievances should be understood', The Evening Post

${ }^{452}$ Graham, "Address by the Minister in Charge of Treaty of Waitangi Negotitaions " 144.
} 
process with Māori was genuine and sincerely open to alteration as the result of the submissions process. Crown Law Office had previously advised that the essence of consultation was in keeping an open mind to the possible outcome and that the Crown must be willing to modify its position once Māori had a chance to respond. Crown Law Office reminded the government that those 'being consulted are not simply to be informed of an impending decision - informing is not consultation. ${ }^{1453} \mathrm{~A}$ model of consultation implies that feedback will be taken on board and have an influence on the outcome of that process. However, as will be demonstrated in this chapter, despite attempts by Māori to engage with and respond to the Proposals, there is very little evidence that feedback from Māori modified the position of the Crown. The vast majority of draft policies were left in place at the end of the consultation process.

For the most part, Māori considered the policies too narrow in their interpretation of the Treaty and principles of justice and that they posed a threat to the current position of Māori under the Treaty. ${ }^{454}$ The government was criticised for participating in a typical "decide-announce-defend' process of law-making'. ${ }^{455}$ Reading through the oral transcripts from the consultation and other references from the period, it emerges that there were tensions between what Māori and the Crown were seeking from a negotiated interaction. Prominent anthropologist Dame Joan Metge has used the term 'talking past each other' to refer to some interactions between Māori and Pākehā. ${ }^{456}$ This concept comes to mind as one considers the Crown's methods of consultation process and Māori reaction to the Crown Proposals. These differences were not always recognised by the Crown, who was committed to address only Article Two breaches of the Treaty through the process of Treaty Settlements. For Māori what was being sought was, at least in part, a matter of 'cultural survival'. ${ }^{457}$ The written and oral submissions from Māori tended to have a wider kaupapa or

\footnotetext{
${ }^{453} 27$ June 1994, 'Consultation with Maori and the Wider Public on Treaty of Waitangi Settlement Policies', CSC (94) M 21/1

${ }^{454}$ See Mason Durie, report on Hirangi hui

${ }^{455}$ Ian Macduff, "The Role of Negotiation: Negotiated Justice?," in Treaty Settlements: The Unfinished Business, ed. Geoff McLay (Wellington: NZ Institute of Advanced Legal Studies and Victoria University of Wellington Law Review, 1995), 56.

${ }^{456}$ Joan Metge and Patricia Kinloch, Talking Past Each Other: Problems of Cross-Cultural Communications (Wellington: Victoria University Press, 1984).

${ }^{457}$ Macduff, "The Role of Negotiation: Negotiated Justice?," 57.
} 
scope than the draft policies themselves. Beginning with the Hirangi hui in January 1995 Māori urged the government to broaden the debate to include a wider consideration of the Treaty as a whole. Some Māori were concerned that the interpretation of the Treaty as represented in the proposals limited the Treaty to property rights under Article Two. There were appeals to include discussion of Māori autonomy or rangatiratanga. To Māori, the issues of settlement of historical grievances and a wider consideration of the Treaty as a whole were inextricably connected. By the time the policies were actually released on 8 December 1994 there was already a great deal of speculation and negativity about the settlement cap and the policies. Māori frustration about the mode of delivery as well as the content of the draft proposals manifested in tension during the consultation hui, and more broadly in actions such as occupations of areas of Crown land during this period.

Several months were set aside for the period of consultation. During this process, ministers and Crown officials travelled to present the proposals and receive feedback at 11 regional hui held on marae around the country. Two planned regional hui were cancelled during the consultation process, and a national hui planned as a conclusion to the process did not go ahead. As well as oral and written submissions received at the hui written responses were encouraged from both Māori and members of the public. This chapter considers reaction to the launch of the Crown Proposals, which for the most part became known as the 'fiscal envelope' policies. Some analysis is made of the submissions process - both the oral and written submissions. Inter-departmental Working Groups of Crown officials were established to analyse the submissions and make recommendations to Cabinet on what changes should be made to the draft policies. These groups reported back in September 1995, 18 months after the initial policy launch. Final recommendations were made in July 1996 . The changes made to the draft policies were minor and did not reflect the response or priorities of Māori. Māori then essentially found themselves unable to make traction in the process, although during this period negotiations continued with Ngāi Tahu and concluded with WaikatoTainui. 


\section{Initial Māori Response to the Crown Proposals}

In September 1994 a draft of the Crown Proposals documents had been leaked and widely circulated. ${ }^{458}$ Through November and December 1994, strong reaction had been building among many Māori to the yet to be announced Crown Proposals, especially because of ongoing reference to the settlement envelope. Some of this response can be attributed to ongoing frustration and mistrust resulting from the 1992 Fisheries settlement, which some iwi felt had been finalised without adequate engagement from all iwi. ${ }^{459} \mathrm{~A}$ hui attended by iwi affected by the raupatu of the 1860s, was held at Ōpōtiki in November 1994, sought to develop a united response to the leaked Crown policies. ${ }^{460}$ Victoria University Lecturer, Caren Wickliffe wrote a column condemning the approach before the policies had even been launched. ${ }^{461}$ Ranginui Walker, in his regular Metro column, kept up a stinging assessment of the Crown's approach. ${ }^{462}$

After the release of the proposals the level of criticism rose; this coincided with the struggle on other Māori issues meaning that the summer of 1995 was a tense time for race relations. Wira Gardiner, Chief Executive of TPK, described the situation as 'volatile'. ${ }^{463}$ There were a number of protest actions and occupations on Crown land in different parts of the country, often as a way of bringing media attention to a longstanding grievance. One of the longest and largest was at Moutoa Gardens in central Whanganui, which was occupied for over 70 days from late February 1995. Protestors there made a direct link between the occupation at Moutoa gardens and the Crown Proposals. 'Through its ill-fated fiscal envelope the Crown has unwittingly provided the cement for the most potent Māori coalition since Bastion Point.' ${ }^{464}$

\footnotetext{
45815 September 1994, 2 YA Mana News Transcript; 1 October 1994, 'Final Treaty settlement takes shape' The New Zealand Herald, 17 November 1994, 'Govt set to make Maori land deal', The Dominion

${ }^{459}$ As noted above the Fisheries Settlement had come under criticism and was not unanimously supported. For more information on the settlement see Moon, The Sealord Deal.;Walker, Ka Whawhai Tonu Matou: Struggle without End 293-99.

46015 September 1994, 'Settlement of Treaty claims thrown into question', 2YA Mana News Transcript; "Te Karanga: Hui Theatre," Metro Magazine, April 1995, 126.

${ }^{461} 1$ November 1994, Caren Wickliffe, 'Flaws in the Consultation Process', The Dominion,

${ }^{462}$ See for example, Walker, "Te Karanga: Pushing the Envelope," 143.; "Te Karanga: Tribal Lolly Scramble," 151.; "Te Karanga: Claim Jumping," 123.

${ }^{463}$ Gardiner, Return to Sender: What Really Happened at the Fiscal Envelope Hui.

46417 March 1995, 'A painful search for the past', The Daily News; Jenny Carlyon \& Diana Morrow, Changing Times: New Zealand since 1945 (Auckland: Auckland University Press, 2013), 368-70.
} 
Whatever the correlation, at the very least the Crown Proposals added a sense of urgency to these issues.

\section{The Hirangi Hui}

Sir Hepi Te Heu Heu, paramount chief of Tūwharetoa, convened a hui at Hirangi Marae, near Turangi, on 29 January 1995 with the purpose of considering the Crown Proposals. Attended by over 1,000 Māori representing most major iwi and Māori organisations, the hui attracted prominent Māori leaders such as former Governor General, Sir Paul Reeves, Speaker of the House Peter Tapsell, and Ngāi Tahu leader Sir Tipene O'Regan, along with activists such as Eva Rickard, Ken Mair and Mike Smith. Those present were critical of the degree of progress the government had made on the policies without conferring with Māori. They rejected the principles upon which the proposals were based, and the framework which defined the approach as being too rigid. ${ }^{465}$ There was also criticism that the government had not referred to its own Principles for Crown Action of the Treaty of Waitangi in the proposals. The hui unanimously passed a resolution rejecting the Crown Proposals. The feeling was that without 'sufficient Māori support the Government would be highly irresponsible to recommend the adoption of the Proposals as national policy. ${ }^{466}$ The delegates also called on the government to stop the sale of Crown land in areas where Māori may have an interest. Those at the hui were concerned that the proposals did not take the Māori version of the Treaty, and issues of tino rangatiratanga in particular into consideration. Delegates called for a wider interpretation of the Treaty and its role in New Zealand's constitution, rather than what they saw as the government's narrow approach, which they claimed reduced Article Two of the Treaty to property rights. ${ }^{467}$ Sir Hepi told the hui that there would

Cate Brett, "Whanganui Beyond the Comfort Zone," North and South, June 1995, 44-59. Durie, Te Māna, Te Kāwanatanga: The Politics of Māori Self-Determination, 125-9.

46530 January 1995, 'Maori reject proposals to settle Treaty claims', 2YA Mana News Transcript; Durie, "Proceedings of a Hui Held at Hirangi Marae Turangi," 20.

466 Durie, "Proceedings of a Hui Held at Hirangi Marae Turangi,", 19.

${ }^{467}$ Moana Jackson later articulated that the compartmentalisation of the Treaty occurred when the articles of the Treaty were considered separately, rather than viewing the Treaty as 'inter-related threads of the same story', Moana Jackson, "Comment," in Treaty Settlements: The Unfinished 
continue to be 'disquiet' until constitutional arrangements were addressed. ${ }^{468}$ The hui reflected a broader reading of contemporary New Zealand; historical Treaty grievances were considered inseparable from questions of Māori self-determination

In response, the government dismissed the hui as not being representative of all Māori, with Graham referring to the hui as premature and uninformed. He considered that it was too soon to reject the Crown Proposals: '[t]hey can do what they like but I think it would have been wiser to wait to hear what it's all about before condemning things'. ${ }^{469}$ Graham also sought to distinguish between the 'fiscal envelope' and the rest of the policies. ${ }^{470}$ It was however too late for this separation, having been presented in the same package, the non-negotiable $\$ 1$ billion settlement envelope and the rest of the policies were indistinguishable in the minds of Māori and the public. This was a distinction that Graham repeated at the time (and continues to make), but by introducing both strands of policy simultaneously in the Crown Proposals, Cabinet had lost the opportunity to consider these aspects separately. The Prime Minister, Jim Bolger, pointed to the signing of a Heads of Agreement between Waikato-Tainui and the Crown in December 1994 as an indication that the Hirangi hui did not have universal representation. The Prime Minister also commented, that the Waikato-Tainui claim was the largest in the country, while 'Sir Hepi's tribe do not have significant claims out against the Treaty of Waitangi at all'. ${ }^{471}$ Archie Taiaroa, Chairperson of the Hirangi hui, indicated that the issue was not as straightforward as the Prime Minister was suggesting: he reported that there were quite a large number of Tainui at the hui and that the 'call for rejection was unanimous even by representatives within the Tainui Confederation.' ${ }^{472}$

\footnotetext{
Business, ed. Geoff McLay (Wellington: NZ Institute of Advanced Legal Studies and Victoria University of Wellington Law Review, 1995), 155. see also "Smashing Cups and Muriwhenua," Kia Hiwa Ra: National Maori Newspaper, May 1997, 25.

46830 January 1995, 'Maoris reject fiscal envelope, 'The Dominion

469 ibid

47030 January 1995, 'Maori reject proposal to settle Treaty claims', 2YA Mana News Transcript.

471 In part this reinforces concerns that the full extent of all claims was not known by government at this time.

47230 January 1995, 'Maori reject proposal to settle Treaty claims', 2YA Mana News Transcript.
} 
Both Graham and Bolger wholly rejected the calls for a wider constitutional debate. Graham also differentiated between historical land grievances and issues of sovereignty, thus rejecting the hui attendees conflation of the two issues: 'Maori sovereignty and constitutional issues are much more complicated' and that was not the purpose of the proposals. ${ }^{473}$ The government did not acknowledge the mana of those who had gathered at Hirangi, or the weight of what they had to say, yet the sentiment generated at the hui and the government's reaction to it contributed to a backlash on Waitangi Day and set the tone for the regional consultation hui. ${ }^{474}$ This was clearly signalled at the first of the regional hui, when Te Kuru o te Marama Waaka stated: 'Sir Hepi Te Heuheu by his presence here only embodies the fact that at Hirangi the whole of the Māori race rejected the fiscal envelope.' 475

On Waitangi day itself, during the pōwhiri for the official party, many of the speakers expressed anger towards the government and the fiscal envelope policies. Tensions were high and at times, spilled over. The official evening programme was cancelled due to security concerns. The following day, newspaper headlines referred to New Zealand's 'Waitangi Day of shame' and 'Waitangi Day disgrace'. ${ }^{476}$ There was concern expressed about what this meant for New Zealand as a country. The Prime Minister called for a review after the 'chaos' of the day and suggested relocating future official Waitangi Day celebrations. ${ }^{477}$ Political commentator Colin James reflected public sentiment when he expressed concern about the behaviour of Māori protestors on Waitangi Day. ${ }^{478}$ The editorial of the National Business Review claimed that 'not many countries would tolerate their flag being trampled on or their acting head of state spat at on what should be a national day of unity. Public tolerance of these activists is wearing thin. ${ }^{479}$

\footnotetext{
47330 January 1995, 'Doug Graham - Hui at Turangi', 2ZB Radio Transcript

4741 March 1995, 'Pushing the Envelope', The Evening Post; Walker, "Te Karanga: Claim Jumping."

${ }^{475}$ Gardiner, Return to Sender: What Really Happened at the Fiscal Envelope Hui, 70.

4767 February 1995, 'PM pledges review after Waitangi Day 'disgrace", The Dominion; 7 February 1995, 'Waitangi Day of Shame', The Evening Post; 10 February 1995 'Waitangi woes surmountable', The National Business Review, For further analysis on the reporting of events on Waitangi Day see Sue Abel, Shaping the News: Waitangi Day on Television, Auckland, 1997

4777 February 1995, 'PM pledges review after Waitangi Day 'disgrace", The Dominion

${ }^{478}$ Colin James, "Hey - Isn't the Government Supposed to Be in Charge?," The National Business Review, 10 February 1995, 13.

479 Editorial, 'Waitangi Woes Surmountable', The National Business Review, 10 February 1995
} 
Not surprisingly Māori saw the situation differently; they regarded the Crown Proposals as provocative and chose the day that commemorated the formal relationship between Māori and the Crown to vent their protest. Ranginui Walker claimed that Graham's dismissal of the Turangi hui, combined with the government's determination to press ahead with the regional hui led to the level of opposition expressed at Waitangi. According to Walker, by continuing with its predetermined plan of action, the government gave the activists carte blanche to deliver the message against the fiscal envelope a second time, and in a more vehement manner. ${ }^{480}$ One of those activists, Hone Harawira, regarded the day as a 'success for the whole of Maoridom'. ${ }^{481}$ Sir Graham Latimer, as Chair of the Māori Council, claimed that the consultation process was being rushed and called on the government to delay it. He suggested that 12 months be taken for Māori to consider their position. ${ }^{482}$ Api Mahuika, Chair of Te Rūnanganui o Ngāti Porou, was critical of the fact that 'the Government has single-handedly developed its parameters for consultation and iwi had been merely asked to respond.' 483 Even Edward Durie, as Chairman of the Waitangi Tribunal, pointed out that all the power seemed to reside with the Crown in Treaty negotiations. ${ }^{484}$

\section{The Consultation Hui}

Following the tensions, protests and security risks to dignitaries and officials on Waitangi Day, it was not clear whether the consultation hui would be able to continue as planned. There were rumours of ongoing protest action and potential risks to the safety of ministers and Crown officials. The possibility of cancelling the hui and receiving only written submissions was briefly considered, but the decision was made to approach each hui on a case by case basis. The Prime Minister put the onus onto marae elders to reign in the 'radicals': he was not prepared to put ministers or Crown officials in any danger. ${ }^{485}$ Te Puni Kōkiri was the government

\footnotetext{
${ }^{480}$ Walker, "Te Karanga: Hui Theatre," 126.

4817 February 1995, 'Waitangi Day of Shame', The Evening Post

4829 February 1995, 'Fiscal-envelope huis may be cancelled', The Dominion

48313 February 1995, 'Cabinet to weigh future of Treaty huis', New Zealand Herald

4848 February 1995, 'Govt under pressure for tough Maori line', New Zealand Herald

4859 February 1995, 'Govt may cancel fiscal-envelope huis', The Dominion.
} 
department in charge of the planning for the consultation hui, responsible for developing the hui timetable and liaising with Māori to arrange which marae would host the thirteen regional consultation hui, planned to be a key component of the consultation process. Over 75 fulltime TPK staff, including Regional Directors and district office personnel around the country, were responsible for co-ordinating the logistics of the hui. ${ }^{486}$ Those in the regional offices acted as intermediaries between the hosting marae and officials in Wellington, organising both security and the technical recording equipment needed to record oral submissions, as well as liaising and communicating with the host marae in each region to establish the protocol and order of speakers for each hui. Chief Executive Wira Gardiner claimed that over 120 pre-consultation hui had been held with Te Puni Kōkiri personnel around the country, prior to the formal planned consultation hui. ${ }^{487}$

The first regional hui was scheduled to be hosted by Te Arawa at Te Papaiouru Marae, Ohinemutu, Rotorua on 15 February. Rotorua was selected as the location of the first of the regional hui as it was considered that the dominant Te Arawa leadership would ensure that the hui proceedings would not be interrupted, thereby setting the tone for the following hui. ${ }^{488}$ Despite the tension of the day and the presence of 300-400 protesters, the hui did proceed without significant disturbance. The overall sentiment of the hui however, was a rejection of both the policies and the fiscal cap. After that first hui, officials from Te Puni Kōkiri and other departments continued to articulate concerns about the safety of ministers and officials scheduled to attend the hui. Gardiner argued that it was 'hardly surprising that ministers and officials were caught by surprise at the vehemence of the resistance to the Government's attempts to consult. ${ }^{1489}$ On the contrary, if anyone should have been able to read the situation on the ground it ought to have been Gardiner and his Ministry; after all, it was the role of TPK to liaise through its regional offices to get an

\footnotetext{
${ }^{486}$ ibid

${ }^{487}$ Gardiner, Return to Sender: What Really Happened at the Fiscal Envelope Hui, 48. It has not been possible to assess the content or location of these meetings, or indeed whether these meetings even took place. The author has been unable to locate any further evidence about them, nor does Te Puni Kōkiri hold any record of them; communication from Michelle Hippolite, Chief Executive Officer, Te Puni Kōkiri, 29 January 2015.

${ }^{488}$ Gardiner, 55

${ }^{489}$ Gardiner, 77
} 
understanding of what was happening around the country, and it had supposedly held more than a hundred pre-hui meetings.

The second hui, hosted by Mataatua iwi, went ahead at Te Rere marae, Ōpōtiki on 18 February. Professor Hirini Moko Mead, Chairman of Ngāti Awa, addressed the crowd:

we support the government's claimed intention to settle outstanding grievances as soon as possible. We recognise that settlement proposals have been put before Māori for discussion. We acknowledge the government's claimed commitment to the settlement process. However, Ngati Awa rejects the settlement proposals in their present form. There are significant parts of it that are unacceptable to us and these we will describe. ${ }^{490}$

Throughout the succession of hui Graham reiterated that the government was attempting to address historical grievances in a comprehensive manner, rather than letting the issues simmer. He acknowledged that the policies were not popular, with the public or politically, but:

There isn't the slightest doubt that the grievances in many cases, are not only justified, but can hardly even be questioned. That they may have been ignored for far too long. That we cannot be frozen in time and that time has come to try to address those troubles and those sadness's and put them behind us.... ${ }^{491}$

On the other hand he repeated the point that the fiscal envelope was primarily an internal budgetary tool and was not open for discussion.

Other hui proceeded, with an increased security presence, in Tauranga, Gisborne, Te Kuiti, Whanganui, Waitara, Auckland, and Hastings. Two hui were held in the South Island, in Blenheim on 22 March and in Christchurch on 25 March. The hui in Northland scheduled for 11 March, and the Wellington hui due to be held at Waiwhetu marae on $18 \mathrm{March}$, were cancelled due to security concerns. A national hui that had been planned at Parliament, as a conclusion to the regional consultation hui was not pursued because of the negative reaction and tension. Various meetings were also held for members of the public and particularly for conservation and recreational interest groups such as the Royal Forest and Bird Protection

\footnotetext{
${ }_{490}$ Hirini Mead, Chairman of Ngati Awa, Te Rere Marae, Ōpōtiki, 18 February 1995, CN 010304 02, Oral Transcripts, OTS archive, 18-19.

${ }^{491}$ Douglas Graham, Te Rere Marae, Ōpōtiki, 18 February 1995, CN 010304 02, OTS archive, 1-2
} 
Society of New Zealand, the New Zealand Fish and Game Council, and Federated Mountain Clubs of New Zealand which were very motivated to ensure that the conservation estate remained in government control. ${ }^{492}$

While each hui was unique, the overall tenor of the presentations and submissions were unanimous. Even the most temperate speakers berated the Crown for lack of consultation on the formation of policy and limiting the amount to be spent on compensation without sufficient knowledge of all historical claims. The speakers tended to view the Crown Proposals as a starting point, from which the issues could be further debated and refined. Many called, in particular, for more time to consider proposals that had been several years in the making but had only just become available for Māori to consider. Some who addressed the hui described the Crown as simply repeating the colonial domination of the nineteenth century, and acting without sufficient regard for its Treaty partner. Many speakers acknowledged the importance of kanohi ki te kanohi (face to face) meetings about such significant issues. Speakers often demonstrated a diplomatic approach: oral presentations to the representatives of the Crown for the most part were respectful and carefully worded yet underlying this civility was a robust rejection of the draft policies. None of this should have been a surprise; while marae tikanga or protocol determines that manuhiri (guests) are treated with respect, the marae is a location for robust debate. $^{493}$ The consultation hui were no exception, especially given the magnitude of the issues. Walker drew attention to the theatrical aspects of the marae: 'the prancing haka, baring buttocks, spitting on the ground, stomping on a flag, are ritual gestures of defiance against the power of government. ${ }^{494}$ A careful reading of the transcripts from the regional hui demonstrate this delicate balance between maintaining protocol and expressing displeasure at the policies. Part of what was displayed at the hui was the rhetoric of the marae or what Anne Salmond refers to as 'the rituals of encounter'. ${ }^{495}$

\footnotetext{
492 It is outside the scope of this thesis to focus on the details of these meetings.

${ }_{493}$ Hirini Moko Mead, Tikanga Māori : Living by Māori Values (Wellington: Huia, 2003), 118.

494 Walker, "Te Karanga: Hui Theatre," 127.

495 Anne Salmond, Hui: A Study of Maori Ceremonial Gatherings (Auckland: Reed Books, 1994), chapter 5 .
} 
The vast majority of speakers at these hui saw the proposals as the beginning of a dialogue between themselves and the Crown. While they did not support the fiscal envelope or other proposed policies, many indicated that their iwi sought to work with the government to find an acceptable solution. A written submission by Nick Tupara and Kerekere Smiler, handed over at the Gisborne hui, was an example of this. The submission expressed opposition to the fiscal envelope, but went on to state a desire 'to have a dialogue' with the government to re-design 'the Envelope to meet with the requirements of both the Crown and us; the Treaty Partners. ${ }^{496}$ A similar related sentiment was expressed by Dan Te Kanawa of Ngāti Maniapoto when addressing the Waikato hui three days later:

Ministers this submission has been prepared only as a preliminary response to the Crown's proposal for the Treaty of Waitangi settlement claims process. It cannot be regarded as a comprehensive response from Ngati Maniapoto simply because our people have not had what we regard as a reasonable amount of time to give full and thorough consideration to all aspects of the proposal and to present a consensus view which incorporates their own proposal for settlements. ${ }^{497}$

Likewise, at the Taranaki hui, Huirangi Waikerepuru of Ngāti Ruanui stated: 'you have had four years to consider these issues, can we have the same. ${ }^{498}$

A prominent feature throughout the hui was that each speaker explicitly sought to speak only for the iwi they were representing, not for other groups. The written $\mathrm{Ng}$ āti Porou submission is an example of this:

Ngati Porou rejects the Crown Proposals for the Settlement of Treaty of Waitangi Claims. Ngati Porou supports the sentiments of the Hirangi Hui convened by Sir Hepi Te Heuheu in February 1995 but have reserved the right to deal with Ngati Porou concerns relating to the Crown's Proposals for the Settlement of Treaty of Waitangi Claims through our own leadership. ${ }^{499}$

Many Māori providing oral and written submissions at the hui were also concerned about what they saw as the compartmentalisation of the Treaty. For example, June Mariu, speaking on behalf of Nga Whaea o te Motu, reminded the Auckland hui that

\footnotetext{
${ }^{496}$ Nick Tupara and Kerekere Smiler, 22 February 1995, written submission received at Gisborne Hui CN 010305 01, OTS archive

${ }_{497}$ Dan Te Kanawa, Ngati Maniapoto, Waikato hui, Tokanganui-A-Noho marae, 25 February 1995 CN 01030602

${ }^{498}$ Gardiner, Return to Sender: What Really Happened at the Fiscal Envelope Hui, 157-8.

${ }^{499}$ Te Runanga o Ngati Porou, 22 February 1995, written submission received at Gisborne hui, CN 010305 01, OTS archive
} 
the Treaty was not just about land: 'wider issues such as health, economic development and housing also needed to be taken into account when considering the Treaty. ${ }^{\prime 500}$

At the final regional hui held in Christchurch on 25 March 1995, all of the speakers were Ngāi Tahu, and were understandably focussed on their own negotiations taking place at the time. They were highly critical of the government's approach to those negotiations and to the concept of trying to establish a comparative order between different claims. Ngāi Tahu members were not interested in discussing other iwi or the details of their negotiations. ${ }^{501}$ Despite the various locations and diversity of iwi, the message from all of the hui was clear,

a unanimous message went out to the Crown, definitively rejecting the imposed fiscal envelope as a massive violation of rangatiratanga. Delegates noted, in particular, that no partnership of the type supposedly embodied in the Treaty could tolerate unilateral pronouncements from one side, especially on a subject so crucial as resolving past breaches of the Treaty. ${ }^{502}$

\section{Written Submissions}

As part of the consultation process written submissions were also invited. The original deadline for receiving written submissions of 19 May 1995 was timed so that submissions generated from the planned April national hui could be included. Due to the negative reaction to the Crown Proposals, in March Cabinet deferred making a decision on whether the national hui should go ahead. It also agreed to extend the date for receiving submissions to 10 September $1995 .{ }^{503}$ But before the September deadline for submissions, officials and Graham were already reassessing the consultation process in light of the response to the Crown Proposals. The papers presented to Cabinet Strategy Committee and to Cabinet in the months of August and September 1995, reflect a more conciliatory approach to the position many Māori had been articulating over the previous months, since the release of the draft

\footnotetext{
${ }^{500}$ Gardiner, Return to Sender: What Really Happened at the Fiscal Envelope Hui, 170.

501 See Gardiner, 208. There was some tension between Graham and Ngāi Tahu at this time. see for example 10 February 1995, 'Figure Wrong - Ngāi Tahu', The National Business Review 502 Hill, Maori and the State: Crown-Maori Relations in New Zealand/Aotearoa, 1950-2000, 262. 50313 March 1995, 'Additional item: Treaty of Waitangi settlement envelope: Consultation process', $\mathrm{CAB}(95) \mathrm{M} 8 / 23$
} 
proposals. ${ }^{504}$ These papers referred to the need to keep Māori 'as Treaty partner' informed of the process, but noted that there was no need to keep special interest groups up to date. This position is an about-turn from the initial government response and demonstrates some degree of accommodation of what Māori had been saying through the regional hui, written submissions and other forums.

A prime example of the change of government attitude was a proposed joint CrownMāori working group to undertake analysis of the written submissions. This resulted from the opposition expressed at Hirangi and the regional hui, and the call for the Crown to recognise its Treat partner. Graham advocated that the summary and analysis of the submissions needed to be 'open to scrutiny from the Treaty partner prior to the general public'. ${ }^{505}$ It was suggested that establishing a working party, made up of four Crown and four Māori nominees would address some of the disquiet expressed by Māori at not being consulted during the development of the policy proposals. Graham suggested that Māori, not the government, should put forward their nominees, and that a planned second hui at Hirangi called by Sir Hepi could be an ideal time for this to be discussed. He informed the Cabinet Strategy Committee:

I believe that a hui convened under the auspices of Sir Hepi Te Heu Heu can be considered representative of Maori interests...The resolutions passed at the first Hirangi hui have been widely endorsed by Maori groups in public statements and in submissions made in the consultation process on the Crown's Treaty settlement proposals as reflecting a basis for their views. Accordingly the outcome of the reconvening of that hui can be relied upon to give an authoritative indication of Maori views on the process issues upon which the Crown seeks input. ${ }^{506}$

Graham's attitude compared with his reaction to the first Hirangi hui was notable and reflected how the events of the previous months had significantly affected his earlier self-assurance. It was proposed that the Prime Minister write to Sir Hepi recommending the establishment of the joint working group and inviting Māori to be part of the process of analysing the submissions. The limitations of this invitation were to be clearly spelt out: 'the extent of Maori participation will be limited to the

\footnotetext{
504 If this had reached the level of Cabinet Strategy Committee papers it must have been the subject of many discussions and meetings before this.

50522 August 1995 (deferred until 5 September 1995), 'Treaty of Waitangi Settlement Proposals: Process for managing submissions' CSC (95) 150, 2.

${ }^{506} 22$ August 1995 (deferred until 5 September 1995), 'Treaty of Waitangi Settlement Proposals: Process for managing submissions' CSC (95) 150, 3.
} 
participation in the analysis phase', although Māori were to have an opportunity to comment directly to ministers on the proposals. ${ }^{507}$ The Prime Minister met with Sir Hepi on 31 August 1995, prior to the second Hirangi hui, at which time he declined the invitation to be involved. Given the reaction of Bolger and Graham to the first Hirangi hui this can hardly have been a surprise. The government's new found consideration for the Treaty partner appeared somewhat limited: when Sir Hepi declined the invitation to be involved in the joint working group, the proposal was not pursued further and Crown officials continued to work on processing the submissions alone. ${ }^{508}$ This was another example of the Crown putting limitations on accommodating Māori assertion of rights.

\section{Report of Submissions, December 1995}

The analysis of the written and oral submissions, presented as Report of Submissions: Crown Proposals for the Treaty of Waitangi Claims was published in December 1995. According to the Report, approximately 2077 submissions were received. ${ }^{509}$ These had been logged, coded (according to the aspects of the Crown Proposals it referred to), summarised and loaded into a database of abstracts by the Office of Treaty Settlements. A team from the Ministry of Justice, the Office of Treaty Settlements, Te Puni Kōkiri, and the Treasury considered the submissions and wrote the report. There has not been any historical examination of the Report of Submissions. ${ }^{510}$ This may have been in part because there was so much scepticism about the authenticity of the consultation process that interest had dropped off by the time the report was published. It may also be that the way the information is presented does not allow for any analysis of the data.

\footnotetext{
507 Ibid. A proposed timeline and budget costs were also outlined in the paper

5085 September 1995, 'Settlement of Treaty Claims: Strategic Overview', CSC (95) 160 2.; Office of Treaty Settlements, "Report of Submissions: Crown Proposals for the Treaty of Waitangi Claims," (Office of Treaty Settlements, Department of Justice, 1995), 1.

509 It is not clear why this number was approximate. One would expect that the exact number should have been known.

${ }^{510}$ Mason Durie wrote 'even though the time for submissions was extended, no analysis of them was ever reported.' Durie, Te Māna, Te Kāwanatanga: The Politics of Māori Self-Determination, 193.
} 
The report stated that it did not provide any commentary on 'the quality of ideas, or the practicality of suggestions' and avoided any significant conclusions. ${ }^{511}$ And yet not all submissions were considered equally. Of the written submissions, 880 were categorised as original, including the 166 oral submissions presented at the eleven regional hui. 'Approximately 869' further cards were received, which rejected the Proposals as 'flawed because of their unilateral development; the fiscal envelope as unjust; and recommended re-negotiation with the iwi. ${ }^{1512}$ These cards were distributed on Waitangi Day and at the various hui, and were predominantly disseminated through Māori networks. In addition, 328 form letters were received in support of the Crown retaining control over the whole conservation estate. There is no explanation for why the 'cards' and 'form letters' were treated separately from the original submissions. Given that both were providing a clearly identifiable response to the Crown Proposals, it is difficult to understand the rationale for separating these from the 'original submissions'.

Aside from segregating the cards and form letters, there is little analysis or weighting given to the remaining written submissions in the report. Therefore, it is possible that a submission from an individual may have been given as much credence as one from a rūnanga or an iwi. There is no way to discern the significance of the information being presented, for example:

Only a few submissions explicitly supported the $\$ 1$ billion total size of the envelope. Most who criticised the amount commented that it was too low, too rigid or arbitrary.... Others said that the $\$ 1$ billion amount breached the Crown's obligations under existing legislation, or the Treaty, and a personal submission stated that Māori have spent over $\$ 1$ billion already in courts trying to get their rights upheld, so the amount of the envelope would reimburse their costs, but do nothing in the way of compensation. ${ }^{513}$

The language is obfuscatory, perhaps deliberately so. For example terms such as 'Many of the submitters...', 'Some submissions...', 'only a few submissions...', and 'some submissions called for...' are used throughout. ${ }^{514}$ There is no way for the reader to know how many submissions made up the 'only a few' that supported the

\footnotetext{
511 Settlements, "Report of Submissions: Crown Proposals for the Treaty of Waitangi Claims," 9.

512 Settlements, "Report of Submissions", 5. Again it is unclear why this number was recorded as being 'approximate'

513 Settlements, "Report of Submissions", 43Settlements, "Report of Submissions: Crown Proposals for the Treaty of Waitangi Claims," 43.

514 Settlements, "Report of Submissions" section 5.4, 42-44.
} 
\$1 billion envelope, or whether these submitters were Māori, non-Māori, individuals or representative of an organisation. ${ }^{515}$ Neither is it possible to assess how much weight the oral submissions recorded at the regional hui were given in this process. As described above, the speakers at those hui had been selected to represent specific iwi or groups for the occasion, yet from the report it is not possible to know how these oral submissions were weighed and analysed against the written submissions received. The report notes that it is not possible to deduce much from these numbers: 'they cannot be taken to be representative of a wider group of people than those who actually made submissions. ${ }^{1516}$ Any analysis within the report was clearly going to be limited. The Report of Submissions claimed that it was not possible to attribute any weighting 'to support for or opposition to the Crown Proposals, as submitters were not asked to identify either their ethnicity or status, or to 'vote' one way or another in respect of the proposals. ${ }^{517}$ This was simply not true: submitters had been asked to identify themselves and whom they represented, and whether they were for or against the proposals and why. They were even asked to identify the page and paragraph heading numbers from the Crown Proposals documents; and to suggest 'new wordings'. ${ }^{518}$ It may have been that not all of the submissions received included this information, but one would expect that the report would have addressed this directly and given a breakdown based on those who did provide the requested information.

It is difficult to see how the report itself could have usefully contributed to informing ongoing policy, when it was unable to provide useful data or analysis on the public reaction to the Crown Proposals. It feels like a missed opportunity, given that the group who prepared the report had complete access to all the submissions. This publically disseminated examination of the submissions appears to be more imprecise than analysis in internal Crown documents. For example, when the interdepartmental working groups reported back to Cabinet Strategy Committee they included phrases such as 'submissions sought claimant funding outside the

\footnotetext{
${ }^{515}$ Although it was asked for, it is not clear from the report whether submitters had included these details or not.

${ }^{516}$ Office of Treaty Settlements, "Report of Submissions: Crown Proposals for the Treaty of Waitangi Claims," 4.

${ }^{517}$ Ibid.

${ }^{518}$ Crown Proposals for the Settlement of Treaty of Waitangi Claims: Detailed Proposals, 5.
} 
settlement envelope'; 'submissions sought for the costs of gifted lands redress not be charged to the envelope'. ${ }^{519}$ These papers included an analysis of the submissions that was not available in the publically sanctioned summary of the submissions process. Some officials within the Office of Treaty Settlements were frustrated with the 'spin' that was being put on the submissions process, particularly given Māori reaction to the Crown Proposals as demonstrated at the regional hui. There is suggestion that senior managerial decision-making at OTS may have had some influence on the ineffectual way this material was collated and presented to ministers and to the public. ${ }^{520}$

The two areas that attracted the largest number of submissions were on the settlement envelope and on the conservation estate. Of the 880 original submissions, 439 mentioned the settlement envelope. In addition, the 869 cards received rejected the Crown Proposals and described the fiscal envelope as unjust. Some submissions considered that the concept of the envelope was flawed and that there should not be a set amount of money set aside to settle claims (especially given that not all historical claims had been registered by this time). Other submissions were critical that too much money was being set aside for settlements. Perplexingly the breakdown of the submissions does not identify the numbers that considered the amount of the settlement envelope too much and those that considered it insufficient. This would seem to be a distinction fundamental to any ongoing policy analysis and potentially supports the claim that managerial decisionmaking at the highest level of OTS influenced the way this material was presented.

\footnotetext{
${ }^{519} .5$ July 1996, 'Treaty Settlement Policies: reports from working groups', CSC (96) 127, 5

${ }^{520}$ Interview with former Crown Official 2, 25 September 2012
} 
Submissions received on the Settlement Envelope:

\begin{tabular}{|l|c|c|c|c|c|c|}
\hline \multirow{3}{*}{$\begin{array}{l}\text { Settlement } \\
\text { Envelope }\end{array}$} & \multicolumn{2}{|c|}{ Personal } & \multicolumn{2}{c|}{ Organisational } & Other & Total \\
\cline { 2 - 7 } & Māori & Non-Māori & Māori & Non-Māori & \\
\cline { 2 - 7 } & 125 & 68 & 82 & 50 & 114 & 439 \\
\cline { 2 - 7 } & \multicolumn{2}{|l|}{+869 cards rejecting proposals and fiscal envelope } & 1308 \\
\hline
\end{tabular}

Adapted from 'Report of Submissions', 5.

In the Report of Submissions the category of 'other' was used when it was 'not possible to determine the ethnicity of the submitter'. ${ }^{521}$ As will be noted, the number of submitters categorised as 'other' was almost as large as the number of personal Māori submissions on the settlement envelope.

While the majority of written submissions from Māori did not support the Crown Proposals, many expressed a desire to keep dialogue open with the Crown. Some groups argued that the government were now limiting concepts of rangatiratanga to simple property rights. ${ }^{522}$ Māori were not alone in questioning the approach the government had taken with proposals. Some church groups and social justice groups were critical of the process and of the $\$ 1$ billion cap. Several prominent lawyers and academics also spoke up about the proposals and the nature of the consultation process.

The second most popular subject of submissions was that of the conservation estate; of the 880 original submissions received, 421 mentioned it. ${ }^{523}$ In addition, 'approximately 328 form letters' were received urging the government to retain control of the conservation estate. ${ }^{524}$ The policies concerning the conservation estate motivated non-claimant respondents, including individual Pākehā and Pākehā

\footnotetext{
${ }^{521}$ Office of Treaty Settlements, "Report of Submissions: Crown Proposals for the Treaty of Waitangi Claims," 4.

522 "The Fiscal Envelope and the Treaty Settlement Proposals," in The Fiscal Envelope: Economics, Politics \& Colonisation Volume 1 (Auckland: Moko Productions, 1995), 13.

${ }_{523}$ Some submissions traversed more than one topic

${ }^{524}$ Again, it is not clear why the exact number would not be known
} 
dominated interest groups, such as the Royal Forest and Bird Protection Society of New Zealand Forest and Bird and Federated Mountain Clubs of New Zealand.

Submissions received on the Settlement Envelope:

\begin{tabular}{|c|c|c|c|c|c|c|}
\hline \multirow{2}{*}{ Conservation } & \multicolumn{2}{|r|}{ Personal } & \multicolumn{2}{|c|}{ Organisational } & \multirow[t]{2}{*}{ Other } & \multirow[t]{2}{*}{ Total } \\
\hline & Māori & Non-Māori & Māori & Non-Māori & & \\
\hline \multirow{2}{*}{ Estate } & 45 & 40 & 44 & 80 & 212 & 421 \\
\hline & \multicolumn{5}{|c|}{$\begin{array}{l}+328 \text { form letters in favour of Government retaining } \\
\text { control of conservation estate }\end{array}$} & 749 \\
\hline
\end{tabular}

Adapted from 'Report of Submissions', 5.

Given that the submissions were not evaluated and presented in the robust manner that had originally been planned, it is difficult to know how much importance was attributed to the report at the time. The report appeared to have been produced to meet the undertaking of the consultation process but its usefulness as an analytical tool for ministers, officials, those who had made submissions, and the public is limited. The best conclusion a reader can draw is that there were a variety of opinions expressed. At the time, the monthly Māori Law Review noted that although the Crown Proposals had generated a lot of interest through the country, the analysis as presented did not advance the issues. ${ }^{525}$

An examination of internal documents reveals that the language used in internal Crown documents was more direct than in the published Report on Submissions. An appendix to a September Cabinet Strategy Committee paper entitled 'Review of the Crown's Treaty Settlement Policy Proposals' is an example of this. ${ }^{526}$ An appendix entitled 'Flavour of submissions' is less ambiguous than the published Report on Submissions. It notes that of the 235 submissions coded by 1 September, the major issues were the rejection of the concept of the fiscal envelope,

525 "Report of Submissions: Crown Proposals for the Treaty of Waitangi Claims," Māori Law Review: A Monthly Review of Law Affecting Māori, Dec 1995-Jan 1996. http://Māorilawreview.co.nz/1996/01/, accessed 17 July 2014

${ }^{526} 5$ September 1995, 'Treaty of Waitangi Settlement Proposals: process of managing submissions, $\operatorname{CSC}(95), 161$. 
concerns about costs to be included or excluded from the envelope, the issue of full and final settlement and, the use of the conservation estate in settlement. No breakdown is provided as to the number of submissions for or against these topics. A 'major concern' that emerged from the submissions was the perception of the Crown as 'judge and jury, having developed the proposals in isolation, without adequate consultation. ${ }^{527}$ The language used here is more frank than the later published analysis.

\section{Crown Response to the Submissions Process}

On 5 September 1995 a group of seven interrelated papers on the Crown Proposals and the settlement of Treaty claims and on the wider Crown-Māori relationship were presented to Cabinet Strategy Committee. ${ }^{528}$ Reading across all the papers provide an insight to the main concerns of government as the official consultation process was drawing to a close. One of the papers entitled, 'Settlement of Treaty Claims: Strategic Overview' identified the inherent tensions within the settlement process. According to the paper Māori were frustrated by difficulties in getting claims addressed and about the constitutional status of the Treaty; they were also resentful about ongoing social and economic disadvantage. Non-Māori, on the other hand were described as wanting grievances to come to an end. The tension for government was in trying to bridge the gap between the two perspectives. ${ }^{529}$

Another one of the papers to Cabinet Strategy Committee was 'Government's Treaty Claim Settlement Strategy: Work Programme', which opened with the words; 'Maori have reacted negatively to the policy proposals released in December 1994, but have not rejected them out of hand. ${ }^{530}$ The paper pointed to the Waikato-Tainui

\footnotetext{
${ }^{527} 5$ September 1995, 'Treaty of Waitangi Settlement Proposals: process of managing submissions, CSC (95), Appendix 1

${ }^{528} 5$ September 1995, 'Waitangi Tribunal Review Process', CSC (95) 155; 'Review of Protection Mechanism' CSC (95) 156; 'Crown-Māori Relationships: Summary of Papers', CSC (95) 157;

'Government's Treaty Claim Settlement Strategy: Work Programme', CSC (95) 158; 'Crown-Māori Governance Issues', CSC (95) 159; 'Settlement of Treaty Claims: Strategic Overview', CSC (95) 160; 'Review of the Crown's Treaty Proposals', CSC (95) 161

${ }^{529} 5$ September 1995, Settlement of Treaty Claims: Strategic Overview, CSC (95) 160

5305 September 1995, Government's Treaty Claim Settlement Strategy: Work Programme, CSC (95) 158
} 
settlement and the announcement about the Crown Settlement Portfolio, a type of land-bank for areas affected by raupatu, as having 'engendered some goodwill and momentum' for claimants. ${ }^{531}$ The general assessment was that the process had gone too far and could not now be abandoned; 'standing still is not an option for the Government if Treaty settlements are to be negotiated rather than settled in court.' 532 The paper set out a proposed policy work programme for the following six months, which included 'refining the policy framework', continuing individual negotiations, and 'developing a dialogue focussed on practical aspects of Māori constitutional concerns'. The fact that advisors were recommending that the government 'refine' the policies, not transform them or abandon them and begin again is a further indication that the consultation process had never been an opportunity to influence a complete rethink of the Crown Proposals.

Officials were also reporting on matters relating to the demands on the fiscal envelope. In particular they focussed on the 'relativity commitment' and the need to get a better understanding of the large number of claims registered. The first issue related to the relativity clause, which included in the Waikato-Tainui heads of agreement signed in December 1994. The clause provided that the compensation to be paid to Waikato-Tainui was $\$ 170$ million or 17 percent of the total amount of the fiscal envelope. The Waikato-Tainui negotiators had insisted on the inclusion of a relativity clause as a way of mitigating its risk as the first major claim to be settled under the restriction of the $\$ 1$ billion fiscal envelope. Now officials were indicating that ministers needed to consider the implications of offering such a clause, including whether there was an expectation to offer such a clause in the course of other negotiations. A further reference to the relativity clause indicated that it had not been part of a planned approach:

\footnotetext{
${ }^{531}$ Ibid. The Crown Settlement Portfolio (CSP) was a new initiative (separate from the Protection Mechanism) to prevent surplus Crown, Crown Health Enterprise and Crown Research Institute properties within the raupatu areas from being sold into private ownership, established by 29 May 1995, CAB (95) M 19/16.

${ }^{532} 5$ September 1995, Government's Treaty Claim Settlement Strategy: Work Programme, CSC (95) 158,1
} 
The relativity clause which the Government agreed to in the Waikato-Tainui settlement opens up a significant policy issue between claims and significant policy risks for the Crown. ${ }^{533}$

Officials also noted that the relativities clause in the Waikato-Tainui settlement complicated the 'overall management of the quantum of total settlement. ${ }^{\text {, } 34}$ These references would strongly suggest that the implications of the inclusion of the relativity clause had not been fully explored before it was included in the WaikatoTainui heads of agreement.

The other main demand on the settlement envelope, as signalled by officials at this time, was the realisation that there was insufficient knowledge on the detail of many of the claims that had yet to be negotiated and settled. Approximately 500 claims had been registered but very little was known about the historical background to these claims, which meant that there was very little understanding about the level of compensation that would be required to successfully settle them. It was pointed out that:

Only a small number are claims of the significance of the Waikato-Tainui raupatu claim. Research to scope the potential significance and fiscal cost has been done for only a limited number of claims. There is a risk that claims may turn out to be more significant than first thought. ${ }^{535}$

These are significant acknowledgments, particularly given that the $\$ 1$ billion cap had been fixed and the 17 percent relativity clause had been negotiated by this stage. They also reinforce the suggestion that the $\$ 1$ billion figure for the settlement envelope was not based on any detailed analysis of historical grievances.

The paper entitled 'Crown-Māori Governance issues', written by Te Puni Kōkiri, noted that the Crown Proposals had raised a number of governance issues, particularly calls for a constitutional review. Many Māori had argued that Treaty settlement policies needed to be addressed in the context of a wider dialogue on the constitutional status of the Treaty of Waitangi. The Hirangi hui at the end of January 1995 , had made this point strongly, calling on the government to clearly state its position on the Treaty of Waitangi before asking for Māori engagement with policies

\footnotetext{
${ }^{533} 5$ September 1995, 'Government's Treaty Claim Settlement Strategy: Work Programme', CSC (95) 158 , para 16

5345 September 1995, 'Settlement of Treaty Claims: Strategic Overview', CSC (95) 160, para 3.3

5355 September 1995, 'Settlement of Treaty Claims: Strategic Overview', CSC (95) 160, para 3.3, 9
} 
on Treaty settlements. ${ }^{536}$ There was a call for greater transparency of the government's position on the Treaty, so that a reasoned evaluation of the submissions could be made. ${ }^{537}$ Māori regarded the Treaty as a holistic entity, rather than compartmentalised fragments where historical Article Two implications were considered in isolation from Article Three obligations. Although Bolger and Graham had moved to shut down discussion on constitutional change very quickly earlier in the year, by September the issue was seen as a 'roadblock' to progressing settlements. The paper recommended that any discussion of Māori constitutional rights be confined to 'ways of giving Māori greater involvement in the management of their own affairs and resources, which do not imply any impairment of the sovereignty of Parliament' and 'options for structures for the national representation of Māori within the existing system of government'. ${ }^{538}$ The National government was not open to the kind of constitutional review that many were calling for in the submissions and at the Hirangi hui; its preference was to simply address historical breaches of article Two. Maria Bargh has been critical of this approach, claiming that it 'sought to limit and govern Māori claims and future structures in forms and ways determined by and expedient for the Crown. ${ }^{539}$

Following Sir Hepi's rejection of the Prime Minister's invitation to take part in the collation of submissions at the end of August 1995, the government continued to work on the submissions without any input from Māori. ${ }^{540}$ Once the submissions had been collated and the Report of Submissions had been published in December 1995 Cabinet agreed that the policy proposals and related Treaty issues should be separated and reviewed by six inter-departmental working groups. These groups focussed on the issues of the negotiations process: settlement envelope and policies with fiscal implications; claimant funding; natural resources; conservation estate; and settlement policy principles and Crown-Māori relations. There was no further reference to getting input from Māori to this part of the analysis process. The

\footnotetext{
${ }^{536}$ Durie, "Proceedings of a Hui Held at Hirangi Marae Turangi," 25-6.

537 The upcoming change to a Mixed Member Proportional electoral system contributed to the motivation for this call.

${ }^{538} 5$ September 1995, 'Crown-Māori Governance Issues', CSC(95) 159

${ }^{539}$ M Bargh, "Maori Development and Neoliberalism," in Resistance: An Indigenous Response to Neoliberalism, ed. M. Bargh (Wellington: Huia, 2007), 32.

540 Office of Treaty Settlements, "Report of Submissions: Crown Proposals for the Treaty of Waitangi Claims," 1.
} 
six inter-departmental working groups considered the submissions on the draft policies and assessed the experience of the negotiation and settlement of claims at that time and then made recommendations on the draft policies as presented in the Crown Proposals. The working-group tasked with analysing the negotiations processes summarised the key problem with the draft policies was a lack of clarity in the way the negotiations processes were presented in the Crown Proposals. It recommended that for the most part the processes should remain in place. One recommended that the step of being accepted onto the Negotiations Work Programme (NWP), be removed. The criteria for being accepted onto the Negotiations Work Programme had included the verification of the historical basis to a claim and the Crown developing a position on the nature and extent of each of the breaches of the claims, all of which required a substantial amount of work being done prior to a claim being formally accepted for negotiations. Officials recommended, on the basis of the submissions and a review of the process that this step be removed from the process and a new updated guide to the process be developed for claimants. ${ }^{541}$ A new guide, setting out the amended negotiation process was published by the Office of Treaty Settlements in $1997 .{ }^{542}$

A summary of the findings and recommendations of the six working groups were reported to Cabinet Strategy Committee on 5 July 1996, a full 18 months after the release of the Crown Proposals. ${ }^{543}$ While there were a few minor suggested changes to the draft policies, the overall message was summed up in the Executive Summary of a Cabinet Paper in July 1996:

After examining the submissions and the last 18 months experience of negotiating and settling claims, working groups are now generally of the view that for the present the most constructive approach is to continue to use the draft policies as guidelines, seeking Ministerial or Cabinet direction where significant exemptions are deemed appropriate. ${ }^{544}$

In other words despite the protests, Māori frustration at the unilateral imposition of the policies, and the concerns identified in the submissions, officials advised that the

\footnotetext{
${ }^{541} 5$ July 1996, 'Treaty Settlement Policies: reports from working groups', CSC (96) 127, 1

542 Office of Treaty Settlements, "Treaty of Waitangi Claims - Direct Negotiation Process. A Booklet Produced by the Office of Treaty Settlements 1997," (Office of Treaty Settlements, Ministry for Justice, 1997).

${ }^{543} 5$ July 1996, 'Treaty Settlement policies: reports from Working Groups', CSC (96) 127 544 ibid
} 
government continue to use the draft policies. The Cabinet paper pointed out that in the period since the release of the Crown Proposals claimants had continued to approach the Crown for negotiations, all of which had relied on the Crown Proposals as a guideline. ${ }^{545}$ The Waikato-Tainui raupatu negotiations were pointed to as an example of the success of this approach. In light of this, officials suggested that using the draft policies as a guideline but recognising the individual imperatives presented by each claim offered the best approach to resolving historical grievances. ${ }^{546}$

Officials wrote that it was outside their mandate to provide any advice on the concept or quantum of the Envelope. It was noted that the submissions:

generally rejected the concept of the Envelope on the basis that it was developed without consultation with Māori, was non-negotiable and unduly focused the settlement process on the financial dimension. Submissions also generally rejected the quantum of the Envelope on the basis that it was insufficient to deliver durable settlements, and was arbitrarily derived. ${ }^{547}$

However, despite the 'significant measure of rejection of the Envelope', there had still been willingness for some claimants to negotiate and settle within the parameters. ${ }^{548}$ Both Bolger and Graham had made much of the success and the willingness of claimants, Waikato-Tainui in particular, to negotiate in the climate of the Crown Proposals. ${ }^{549}$ The reality was that for Māori who were seeking to resolve historical grievances there was no choice but to engage with the process. Although there was a tendency for the government to think that because groups were engaging with the Crown to negotiate their claims they were supportive of the new policies. This is too simplistic. In fact many claimants remained frustrated about the lack of change resulting from the consultation process and the limitations imposed

\footnotetext{
${ }^{545}$ It should be noted that the Waikato-Tainui claim (wai 30) 22 May 1995, and Waimamaku claim (wai 147) 20 December 1995 were the only claims that were settled between the launch of the Crown Proposals and the time of this Cabinet paper. Ngāi Tahu was in formal negotiations during this period. It would appear that Rotoma (wai 90) and Te Maunga (wai 315) were also in formal negotiations at this time, as both of these groups signed deeds of settlement with the Crown in October 1996. http://www.ots.govt.nz/, accessed 19 November 2014

${ }^{546} 5$ July 1996, 'Treaty Settlement policies: reports from Working Groups', CSC (96) 127 , para 15

5475 July 1996, 'Treaty Settlement policies: reports from Working Groups', CSC (96) 127, para 18

5485 July 1996, 'Treaty Settlement policies: reports from Working Groups', CSC(96) 127, 4

${ }^{549}$ For example 30 January 1995, 'Maori reject proposal to settle Treaty claims', 2 YA Mana News Transcript. Bolger emphasised the 'extraordinarily important decision made by the largest tribal confederation in New Zealand...to resolve their outstanding claims under the government's broad package of proposals.'
} 
on them by the negotiations process, but were motivated to settle for reasons that suited their own circumstances. ${ }^{550}$ For example Waikato-Tainui had reservations about engaging with the Crown and opposed the Crown Proposals, but considered that the time was right to end its raupatu grievance. ${ }^{551}$ In a similar manner, Tipene O'Regan lead negotiator for Ngāi Tahu, described himself as one in a long line ('a five-generation battle') seeking rangatiratanga for Ngāi Tahu. He continued:

Ngāi Tahu may or may not get a settlement in my lifetime. I don't know whether the Pākehā power culture really wants to make a settlement. But if it doesn't happen this generation, the next generation will do it...My dream has been to move our people out of grievance mode into development mode. But they will never come out of grievance mode until there's a settlement. ${ }^{552}$

Ngāi Tahu did eventually negotiate a \$170 million settlement within the confines of the settlement envelope despite earlier asserting that the proposals were designed to limit its claims, which it had estimated at significantly higher. ${ }^{553}$ The small Waimakuku claim was the other example of a settlement being reached during this period: a settlement was signed with the whanau group on 20 December $1995 .{ }^{554}$ The claim had been accepted onto the Negotiations Work Programme in May 1995, the same month that submissions were originally due on the Crown Proposals. The settlement acknowledged a Treaty breach that had occurred in 1929, some 66 years previously. Although this was a small, discrete claim its successful negotiation and settlement was used as a way to bolster government claims of acceptance of the Crown Proposals.

Along with recommending that the vast majority of draft policies remain in place, officials advocated that communication on these issues should be shaped to emphasise that the government was focussed on settling individual historical Treaty grievances and on ways to increase Māori control over Māori affairs'; that work on

\footnotetext{
${ }^{550}$ For examples of claimant negotiators' experiences of the negotiating with the Crown see CFRT, "Maori Experiences of the Direct Negotiation Process," (Wellington: Crown Forestry Rental Trust, 2003), part 5.

${ }^{551}$ Fisher, "Balancing Rangatiratanga and Kawanatanga: Waikato-Tainui and Ngāi Tahu's Treaty Settlement Negotiations with the Crown," 136.

${ }^{552}$ Tipene O'Regan, "Readying the Canoe on the Beach," in Vision Aotearoa: Kaupapa New Zealand ed. Witi Ihimaera, Roslie Capper and Amy Brown (Wellington: Bridget Williams Books, 1994), 47. ${ }^{553}$ There was disagreement between Ngāi Tahu and the government the amount of reparation that should be paid to compensate for breaches of the Treaty. Fisher, "Balancing Rangatiratanga and Kawanatanga: Waikato-Tainui and Ngāi Tahu's Treaty Settlement Negotiations with the Crown," 108. ${ }_{554}$ The claim was registered as wai 147; https://www.govt.nz/dmsdocument/3754, accessed 5 September 2015
} 
the policies would continue 'informed by' the submissions; and that the government was continuing to 'listen to Maori and all those concerned with the Treaty settlement process. ${ }^{555}$ While officials were keen that the government communicated the message they were continuing to consider the feedback received, and that Māori would have a greater role to play in Māori affairs, there was no real demonstration of this 18 months after the release of the draft policies. The government had committed too much to abandon the proposals at this point. One commentator observed, 'however feeble and flawed the offer is, the Government has set things moving. The trick is to cash in on that momentum. ${ }^{1556}$ In 1997, the Office of Treaty Settlements produced a booklet: 'Treaty of Waitangi claims - Direct Negotiations Process', which was the first public statement of policy since the Crown Proposals. Many of these policies form the basis of the negotiation and settlement policies that are in place today. ${ }^{557}$ Some amendments to the policies took place in the following three years. For example claimant funding was confirmed as a cost of the Crown, rather than an advance on individual settlements. Further, it was agreed that the rentals accumulated from Crown forest licensed land would no longer be deducted from the settlement envelope. ${ }^{558}$

\section{Chapter Conclusion}

The release of the Crown Proposals for the Settlement of Treaty of Waitangi Claims in December 1994 was a watershed moment in the modern Treaty claims settlement process. The following year was dominated by reaction and fall-out to the draft policies and the settlement envelope. Although rumours and draft copies of the Crown Proposals had been circulating it was not until the official release, in December 1994, that Māori were able to read the draft policies and information about the settlement envelope, the government had been working on for several years. Māori reaction to the Proposals was strong. Māori mobilised against the

\footnotetext{
${ }^{555} 5$ July 1996, 'Treaty Settlement Policies: Reports from Working Groups', CSC (96) 127.12

${ }^{556}$ Derek Fox, "A Big Ask of Doug," Mana Magazine, Feb-April 1995, 39.

557 Office of Treaty Settlements, "Treaty of Waitangi Claims - Direct Negotiation Process. A Booklet Produced by the Office of Treaty Settlements 1997." See Settlements, Ka Tika A Muri, Ka Tika $\bar{A}$ Mua: Healing the Past, Building a Future. A Guide to Treaty of Waitangi Claims and Negotiations with the Crown.

${ }^{558} 5$ July 1996, 'Treaty Settlement Policies: Reports from Working Groups', CSC (96) 127.13
} 
approach the Crown had taken; the settlement envelope concept and amount, and the details of the draft policies themselves. Many Māori also engaged with the formal consultation process providing oral submissions and the regional hui and written submissions. Some Pākehā too engaged with the submissions process, particularly in relation to maintaining the status of the conservation estate.

Neither the amount nor the concept of the settlement envelope were open to negotiation and yet it was these aspects that dominated coverage. Many claimed the government had indulged in 'political folly' by insisting on announcing the fiscal envelope along with the rest of the policies. ${ }^{559}$ Graham later reflected that he could understand why the introduction of the cap in 1994 was considered 'offensive, but he argued that it was unavoidable: 'The government wanted to show it was committed to settling claims and to reassure claimants that there would still be money for those at the end of the queue.' Graham pointed out that the Tainui settlement would not have been reached if the Government had not set out its overall budget. ${ }^{560}$

The fiscal envelope aside, the question remains how genuine was the ability for the submissions process to alter policy? Many Māori engaged deeply with the consultation process. The Hirangi hui, held in January 1995 prior to the Crown organised regional consultation hui had concluded that without 'sufficient Māori support the Government would be highly irresponsible to recommend the adoption of the Proposal as national policy. ${ }^{1561}$ Yet, over time, this is exactly what happened. The draft policies were adopted, almost without exception. While there must be an acknowledgement of the progress and commitment of the whole of government to a comprehensive approach to addressing historical breaches of the Treaty; the reality was that very little changed as a result of the process of consultation. This was particularly frustrating for the many Māori who had engaged in the Crown Proposal consultation process in good faith. As has been demonstrated, the consultation process ended up as little more than a box-ticking exercise.

\footnotetext{
${ }^{559}$ Colin James, "Hey- Isn't the Government Supposed to Be in Charge?," The National Business Review, 10 February 1995, 13.

56018 December 1996, 'Lifting of Treaty cap largely symbolic - Graham', The Dominion

561 Durie, "Proceedings of a Hui Held at Hirangi Marae Turangi," 19.
} 


\section{CHAPTER SIX: FROM PARLIAMENT TO THE PAEPAE, POLICIES IN PRACTICE 1996 -1998}

Parallel with the process of the development, release and consultation on the Crown Proposals described in the previous chapter, officials were also engaged in negotiations with a small number of claimant groups. In the course of these negotiations Crown officials used the newly developed draft policies presented in the Crown Proposals as the foundational template for the process. The major negotiations, with both Waikato-Tainui and Ngāi Tahu were conducted under this policy paradigm, even though the policies were still in 'draft' form and both groups expressed opposition to them. ${ }^{562}$ During the consultation process on the Crown Proposals the government was keen to maintain momentum with claims already in negotiation, thus seeking to validate its approach in those proposals and claim some tacit endorsement of the fiscal envelope.

It was considered particularly important that the negotiations with Waikato-Tainui and Ngāi Tahu, whose claims had long been recognised as two of the most significant in the country, reached a settlement within the confines of the Crown Proposals and the fiscal envelope. In short, progress with one or both of these large claims was needed for the fiscal envelope to become a viable strategy, and this chapter focuses on how the policies from the Crown Proposals were applied from 1995 to 1998, specifically in relation to negotiations with Waikato-Tainui and Ngāi Tahu, which established some fundamental practices that remain in place today. One such protocol that, seems to have been introduced in earlier negotiations but was formalised at this time, was negotiations between claimant representatives and Crown representatives were undertaken on a without prejudice, 'in camera' basis. This was agreed to by both claimants and the Crown, and allowed discussions to be confidential and wide-ranging and enabled much needed trust to build up between claimants and those representing the Crown in the negotiations process. It would

\footnotetext{
${ }^{562}$ See Mahuta, "Tainui: A Case Study of Direct Negotiation."; Tipene O'Regan, "A Ngāi Tahu Perspective on Some Treaty Questions," ibid., ed. Geoff Mclay (Wellington: NZ Institute of Advanced Legal Studies and Victoria University of Wellington Law review).
} 
not have been possible to engender the same sense of trust between claimant and Crown negotiators if the negotiations were undertaken in an open forum.

The Crown and Māori have different expectations of the Treaty settlement process. Māori are seeking redress for historical Treaty breaches but also a better relationship with their Treaty partner and a means to assert their autonomy. Although as O'Sullivan has pointed out, the very process of engaging imposes limits on Māori, as the Crown sets the parameters. ${ }^{563}$ The Crown is also motivated to create a better relationship with their Treaty partner, as expressed in a Crown apology. ${ }^{564}$ But the Crown must act in the interests of all New Zealanders, and is therefore also concerned with addressing historical Treaty grievances in a manner deemed acceptable to the whole of society (the vast majority of whom are not Māori). It is not surprising then that there are contested expectations of the Treaty settlement process and its objectives. Meredith Gibbs argued that justice for iwi and the Crown is the principal aim of the Treaty settlement process, although this justice is modified and limited by cultural and temporal constraints. ${ }^{565}$ Some of this modification has taken place through the process of negotiations, and over time these alterations have had significant influence on the settlements negotiated through the Treaty settlement process. The period between 1995 and 1998 signalled a time of increased negotiation activity, and an accelerated level of policy work on the negotiations framework. It also signalled a time for the policies and procedures of the Crown Proposals to move from the realm of officials, ministers and the executive arm of bureaucracy out to claimants, and to the communities and to the marae where the historical injustices had been endured and kept alive through the years.

During this time a number of claimants, including Waikato-Tainui and Ngāi Tahu completed negotiations with the signing of a deed of settlement. There was also a

\footnotetext{
${ }^{563}$ O'Sullivan, Beyond Biculturalism: The Politics of an Indigenous Minority, 60. See also Maria Bargh, "The Post-Settlement World (So Far): Impacts for Māori," in Treaty of Waitangi Settlements, ed. Nicola R. Wheen and Janine Hayward (Wellington: Bridget Williams Books, 2012), 166;

O'Sullivan, Beyond Biculturalism: The Politics of an Indigenous Minority.; and Coates, "International Perspectives on Relations with Indigenous Peoples."

${ }^{564}$ Settlements, Ka Tika $\bar{A}$ Muri, Ka Tika Ā Mua: Healing the Past, Building a Future. A Guide to Treaty of Waitangi Claims and Negotiations with the Crown, 24.

${ }^{565}$ Gibbs, "Are New Zealand Treaty of Waitangi Settlements Achieving Justice? : The Ngāi Tahu Settlement and the Return of Pounamu," 46.
} 
strategy in place through this period to negotiate and settle small claims as quickly as possible. ${ }^{566}$ The consultation process on the draft policies had resulted in minimal change to the proposed process. Rather, modification to the policies and the negotiations process developed over time and emerged from the two parties working together in the process of formal negotiations and this happened when claimants themselves presented priorities for their own claims. I have described this as from Parliament to the paepae. ${ }^{567}$

From the time a concept for a finite settlement fund was established in 1992 and the limit of $\$ 1$ billion announced in December 1994, any room for claimants to exercise autonomy within the negotiation of a Treaty settlement had been restricted. Craig Coxhead and others have been critical that there was in fact very little left to negotiate within the formal negotiations process, given that compensation restricted was by the inclusion of a relativities mechanism for Waikato-Tainui and Ngāi Tahu, and a Crown desire to provide similar levels of compensation for similar types of claims. ${ }^{568}$ Given limitations on funding, the biggest movement on compensation being offered has been outside the limits of financial redress, in the area of cultural redress, together with the development of the Crown apology. ${ }^{569}$ This chapter contends, that while operating under the parameters of the fiscal envelope, it was through the course of individual claimants negotiating directly with the Crown and expressing their priorities for the non-fiscal aspects of their claims, that the settlement process was (and continues to be) modified over time. This chapter focuses on the aspects that were developed in relation to the Waikato-Tainui and the Ngāi Tahu negotiations; in particular the establishment of the Crown Apology in a deed of settlement, which began with the Waikato-Tainui negotiations, and the development of statutory instruments and co-governance relationships, which were

\footnotetext{
${ }^{566}$ Interview with former policy manager at Office of Treaty Settlements, 25 September 2012

567 The paepae refers to the orator's bench on the marae, where formal greetings and discussions take place. It is often the location of robust debate.

${ }^{568}$ Craig Coxhead, "Where Are the Negotiations in the Direct Negotiations of Treaty Settlements?," Waikato Law Review 10 (2002).; Annie Mikaere, "Settlement of Treaty Claims: Full and Final, or Fatally Flawed?," New Zealand Universities Law Review 17, no. 4 (1997).

${ }^{569}$ Cultural redress are those aspects of a deed of settlement that address the 'cultural rather than economic interests of the claimant group.' Settlements, Ka Tika $\bar{A}$ Muri, Ka Tika $\bar{A}$ Mua: Healing the Past, Building a Future. A Guide to Treaty of Waitangi Claims and Negotiations with the Crown, 90.
} 
established through the Ngāi Tahu settlement. I have termed these modifications the 'legacy' aspects of claims.

In addition to these cultural redress aspects, this chapter addresses the claimant priority for the return of Crown land as part of a settlement, and the resulting establishment of land-banking and other protection mechanism schemes. Ngāi Tahu gave priority to establishing its own legal entity, and the return of sites that were of significance to it. Recently chief negotiator O'Regan reflected that the establishment of Te Rūnanga o Ngāi Tahu, which recognised Ngāi Tahu as a legal entity was 'the greatest single achievement' of the Ngāi Tahu negotiating team. ${ }^{570}$

The various types of negotiated outcomes are all attempts at recognising and accommodating Māori autonomy or tino rangatiratanga, albeit in a limited way. These modifications reflect the priorities of claimant groups in the negotiations process which have been picked up and added on to over the years, and developed to an extent not anticipated in the 1990s. For example, the 2013 settlement with Ngāi Tūhoe established a new governance structure to manage the settlement and recognised Te Urewera (previously a National Park), as an independent legal entity. ${ }^{571}$ The Deed of Settlement included Crown acknowledgements of breaches of the Treaty of Waitangi and its principles, including wrongful killing, a scorched-earth strategy, and the confiscation of land, and a Crown apology for these actions. Ngāi Tūhoe's 'mana motuhake', defined as 'maintaining Tūhoe control over every aspect of Tūhoe life', was recognised in the Deed. ${ }^{572}$ The Crown accommodations in the Ngāi Tūhoe settlement are a result of incremental accommodation over the past 20 years of settlement negotiation, and their origins can be traced back to the WaikatoTainui and the Ngāi Tahu negotiations and settlements, which this chapter focuses on. ${ }^{573}$ Likewise, the Whanganui River Settlement in August 2104 recognised that

\footnotetext{
5708 February 2014, 'Man of Mana', Christchurch Press

571 Tūhoe Claims Settlement Act 2014

${ }^{572}$ Te Rangimārie Williams, "Te Mana Motuhake O Tūhoe" (MA thesis, Victoria University of Wellington, 2010), 30.; see also Rawinia Higgins, "Te Wharehou O Tūhoe: The House That 'We' Built," Māori Law Review, October 2014.; Rachael Harris, "The Changing Face of Co-Governance in New Zealand - How Are Ngāi Tahu and Ngāi Tūhoe Promoting the Interests of Their People through Power-Sharing Arrangements in Resource Management?" (MA thesis, University of Canterbury, 2015).

${ }^{573}$ For an in-depth analysis of these two sets of negotiations see Fisher, "Balancing Rangatiratanga and Kawanatanga: Waikato-Tainui and Ngāi Tahu's Treaty Settlement Negotiations with the Crown."
} 
River, its entirety (from the mountain to the sea and all its tributaries) as a legal entity. ${ }^{574}$

On 1 January 1995 the Office of Treaty Settlements (OTS) came into existence and replaced the Treaty of Waitangi Policy Unit (TOWPU). ${ }^{575}$ Belinda Clark, previously a policy manager at Te Puni Kōkiri, was appointed as the new Director. The Office of Treaty Settlements remained in the Department of Justice, but the director reported directly to the Minister in Charge of Treaty of Waitangi Negotiations. ${ }^{576}$ At the time of its creation OTS had a staff of about 40 . Its primary function was to negotiate the settlement of historical grievances under the Treaty of Waitangi and to implement those settlements. It also took on responsibility for the Protection Mechanism for Surplus Crown Land, as well as 'responsibility for the acquisition, management and disposal of land for use in claims settlements', which was to become a growing role for OTS. ${ }^{577}$

\section{The Waikato-Tainui Settlement}

Waikato-Tainui and the Crown had begun the process of direct negotiations with 'scoping negotiations 'in 1989, which had been prompted by the outcome of the Coalcorp case to the Court of Appeal. Justice Robin Cooke had encouraged Tainui and the Crown to resolve their differences through negotiations. ${ }^{578}$ Although the Prime Minister Geoffrey Palmer, did not appreciate the Court of Appeal looking to give direction to the government, Waikato's Chief negotiator Robert Mahuta later identified the Court of Appeal decision as marking a 'turning point in the relationship between the tribe and the Government'. ${ }^{579}$

\footnotetext{
${ }^{574}$ Whanganui iwi and the Crown, 'Ruruku Whakatupua te Mana o te iwi o Whanganui' 5 August 2014, https://www.govt.nz/treaty-settlement-documents/whanganui-iwi/, accessed 15 September 2015

${ }^{575} 22$ September 1994, 'Revised Treaty Negotiations Process' CAB (94) M 31/15, Yellow Book

${ }^{576}$ The Minister of Justice was not necessarily the Minister in Charge of Treaty Negotiations, but during this period Graham held both portfolios

${ }^{577}$ Department of Justice, "Department of Justice Annual Report," (year ended 30 June 1995), 173-4.

${ }^{578}$ Tainui Maori Trust Board V Attorney-General.; McCan, Whatiwhatihoe: The Waikato Raupatu Claim, 281.

${ }^{579}$ Mahuta, "Tainui: A Case Study of Direct Negotiation," 79.
} 
The direct negotiations with Waikato-Tainui were carried out without a Waitangi Tribunal report. Waikato-Tainui had always been very clear on their own history, and did not feel the need to go through the process of a Tribunal inquiry. For the purposes of direct negotiations the Sim Commission report from 1927 and the Waitangi Tribunal's Manukau Report provided contextual background to the raupatu (or confiscation) of over 1.2 million acres following the land wars. ${ }^{580}$ The iwi also drew on their oral knowledge and Crown historians on their knowledge of history from recorded sources. The 'scoping negotiations' which had begun in 1989 resulted in an initial informal offer by the Crown in 1990; which was rejected by the iwi. Negotiations were revived in 1992, but it took some time for Waikato-Tainui's priorities to be recognised and taken on board, specifically the return of raupatu land and a Crown apology.

For the majority of the negotiation process the Crown and Waikato-Tainui were directed by the policies and guidelines set out in the 1990 booklet The Direct Negotiation of Maori Claims. ${ }^{581}$ The negotiations between Tainui and the Crown continued during the period that Crown officials worked on the Crown Proposals policies from 1992 through to their release in December 1994. The release of these proposals and the presentation of a Crown offer to Waikato-Tainui at Turangawaewae marae, just a few weeks later, on 21 December 1994 are inextricably linked. Graham wanted to keep the two processes as co-ordinated as possible and was keen that a settlement with Waikato-Tainui be reached and ideally announced at the same time as the release of the Crown Proposals, a way of giving credibility to the policies. At a meeting in early October 1994 to discuss a proposed timetable for the publication of the Crown Proposals and the Waikato-Tainui settlement, the minister expressed his preference that the release of draft policies and the announcement of the Waikato-Tainui settlement should happen on the same day. He reasoned that the announcements 'needed to be to be synchronised so that one process does not get out of step with the other'. ${ }^{52}$ Crown officials had

\footnotetext{
${ }^{580}$ Sim Commission, AJHR 1928 G7; Tribunal, Report of the Waitangi Tribunal on the Manukau Claim, Wai 8.

${ }^{581}$ Issues, The Direct Negotiation of Maori Claims: An Information Booklet.

582 TOWPU File Note, 4 October 1994, TC 30, OTS archive
} 
earlier indicated that a settlement agreement with Tainui was seen as the best way to ensure the viability and some level of acceptance of the fiscal envelope. ${ }^{583}$

The non-binding Heads of Agreement setting out the details and parameters of the settlement was signed by Mahuta on behalf of Waikato-Tainui and by Graham on behalf of the Crown on 21 December 1994. Negotiations continued to finalise the details of the Heads of Agreement, and Waikato-Tainui sought to have the deal ratified by its registered beneficiaries. During tribal hui, Mahuta emphasised that the settlement was an agreement specifically between Waikato-Tainui and the Crown. The Crown's settlement offer, he said, was a result of Waikato-Tainui's 'sheer hard work, the strength of their convictions, having the courage to endure Maori and Paakeha persecution over the past 100-odd years and an indomitable will to see that the raupatu claim was resolved. ${ }^{584}$ Mahuta did not want Waikato-Tainui's acceptance of the Crown offer to be interpreted as tacit support for the Crown Proposals, which were published after the majority of the negotiations had been completed. He stressed that each iwi had to decide its own response to what the government were presenting. ${ }^{585}$ This did not prevent senior ministers from connecting the successful signing of the Heads of Agreement as an example of the success of the policies.

\section{Return of Crown Land and the Development of Land-banks}

Waikato-Tainui had always sought the return of more than 1 million acres of land that had been confiscated by the Crown in the 1860s, under the 1863 New Zealand Settlements Act. Throughout the negotiations process it was guided by the principle 'i riro whenua atu me hoki whenua mai' (as land was taken land must be returned). It took some time for the significance of Waikato's principle to filter through all aspects of government. Between the time of the initial 'scoping negotiations' between Waikato-Tainui and the Crown in 1989 and the development of the Crown Proposals, however, the priority of returning land did begin to permeate the thinking

\footnotetext{
583 Internal TOWPU Memo, 28 April 1994, T 5/2 Vol 5, OTS archive.

${ }^{584}$ Mahuta, "Tainui: A Case Study of Direct Negotiation," 86.

${ }^{585}$ Mahuta, "Tainui: A Case Study of Direct Negotiation," 85 As noted there were Waikato-Tainui representatives at the Hirangi hui in January 1995.
} 
of the Crown. While many officials who had worked with Waikato-Tainui for some time appreciated this, Graham later reflected: 'I did not realise for some time just how crucial that was. In fact it was everything - much more important than dollars and cents. ${ }^{586}$ By the time of the release of the Crown Proposals, one of the Crown's settlement criteria for all claimant groups was the return of as much Crown land as possible. $^{587}$

Over time a variety of land-banking and other protection mechanisms were introduced to prevent the disposal of Crown land, pending the settlement of claims. ${ }^{588}$ Several systems were established, to address concern from Māori that Crown land was still being disposed of even while Tribunal hearings and negotiations were taking place. ${ }^{589}$ An 'early warning system' had been authorised for Ngāi Tahu in 1990, prompted by its Waitangi Tribunal hearings. The purpose of that system was to identify lands and other assets that may have been of importance to Ngāi Tahu to ensure they were not sold prior to government final decisions on the iwi's claims. ${ }^{590}$ In 1991 a formal land bank was established, administered by the Department of Survey and Land Information (DOSLI). Although in the 1989 Coalcorp case the Court of Appeal declared that the Crown (or its agents) should not dispose of Crown lands until a protective scheme had been put in place. ${ }^{591}$ This was not a straightforward process and only after considerable negotiations was a land-bank specifically for Waikato-Tainui established in 1993. ${ }^{592}$ Also in 1993, Cabinet agreed to establish a national land-banking scheme called the 'Protection Mechanism for Surplus Crown Property', to recognise potential Māori interests in surplus Crown, departmental, or selected Crown entity land, such as Crown

\footnotetext{
${ }^{586}$ Graham, Trick or Treaty?, 72. Officials had been advising on this from the time of scoping negotiations in 1989

${ }^{587}$ Settlements, Crown Proposals for the Settlement of Treaty of Waitangi Claims: Detailed Proposals, 6.

${ }^{588}$ These are different to the section 27B memorials placed on Crown land transferred to State owned Enterprises, which the Waitangi Tribunal (in specific circumstances) has the power to order the resumption of lands. Another separate form of statutory protection is in place from Crown forest land, under provisions of the Crown Forest Assets Act, 1989 For further discussion on the Tribunal's binding powers see Melvin, "The Jurisdiction of the Waitangi Tribunal," 23-26.

${ }_{589}$ The term protection mechanism is now used to describe the variety of methods used to protect Crown assets for use in Treaty settlements, Settlements, Ka Tika $\bar{A}$ Muri, Ka Tika $\bar{A}$ Mua: Healing the Past, Building a Future. A Guide to Treaty of Waitangi Claims and Negotiations with the Crown, 134.

5904 April 1990, SAS (90) M10/3

591 Tainui Maori Trust Board V Attorney-General.

592 This was known as a Claim Specific Land-bank.
} 
Research Institutes. ${ }^{593}$ Under the protection mechanism scheme Crown land which met certain criteria was purchased and held in a land-bank and was then available as redress for a settlement, if required. The scheme was intended to be a stopgap solution, but has remained in place, and has resulted in some properties being held in land-banks for many years; much longer than ever anticipated. ${ }^{594}$

A further mechanism, the Crown Settlement Portfolio (CSP) established in 1995, sought to retain all Crown land within the areas affected by raupatu or confiscation under the 1863 New Zealand Settlements Act. All surplus Crown land within the boundaries of the 1863 legislation were land banked. There was no limit on the value of land that could be held in the CSP. ${ }^{595}$ Graham later reflected how difficult it was to establish these systems, saying that it was a challenge to collate information from government departments about the extent of Crown land held by their portfolios. ${ }^{596}$

\section{Negotiation of the Relativity Clause for Waikato-Tainui}

The Crown and Waikato-Tainui found themselves at somewhat of an impasse in relation the negotiating of redress or compensation for the historical claims. Despite the fact that Waikato-Tainui did not want their negotiations connected with the Crown Proposals and the fiscal envelope, the timing of the negotiations meant that the compensation would be deducted from the fiscal envelope. At the time, Tainui Chief Negotiator Robert Mahuta said that its agreement with the Crown should not be used as a benchmark for other claims, but the government had a different

\footnotetext{
${ }^{593} 3$ May 1993 CAB (93) M 15/33. An amendment to the process was announced 20 November 1995, Press release, 'Protection Mechanism for Surplus Crown property', Minister in Charge of Treaty of Waitangi Negotiations

${ }^{594}$ This issue was raised during the second reading of the Ngāti Manuhiri Claims Settlement Bill, 19 September 2012. Parekura Horomia, Labour's spokesperson on Māori issues, was concerned about the deterioration of properties due to the length of time they were being held in the protection mechanism land-bank. Minister for Treaty of Waitangi Negotiations, Christopher Finlayson agreed, saying that the 'land bank system is under pressure, and I promise him I am on to it'. New Zealand Parliamentary Debates, 19 September 2012

${ }^{595} 20$ June 1995, 'Retention of Crown Surplus land in Raupatu areas: Crown Settlement Portfolio; Implementation Issues' TOW (95) 55

${ }^{596}$ Interview with Sir Douglas Graham, 15 August 2012
} 
perspective. ${ }^{597}$ Graham argued that for settlements to be negotiated and endure there had to be relativity between them. Claims would not be lasting if WaikatoTainui was offered $\$ 170$ million and another group was offered a higher amount. ${ }^{598}$ Another factor which had an impact on quantum related to the nature of the grievances, how much land was involved, the size of the population affected, the nature of the land taking, and whether bloodshed had occurred on the land.

Waikato-Tainui were also wary of the $\$ 1$ billion limit on settlements. First WaikatoTainui had to come to terms with the fact that any compensation offered was a small fraction of the value of the land loss through raupatu, quite apart from losses arising from other grievances, and that any settlement was therefore a compromise for them. Mahuta argued that it was less than two cents in the dollar of the value of land lost to Waikato-Tainui. ${ }^{599}$ The iwi leaders were concerned that the Crown might change its mind on how much money it would need to spend to settle historical claims. If they agreed to a settlement of $\$ 170$ million and the amount of the settlement envelope was later increased, then Waikato-Tainui would find themselves disadvantaged by agreeing to a settlement early in the process. As a compromise, and to mitigate their risk, Waikato-Tainui negotiated that the offer of $\$ 170$ million be indexed to the total expenditure on historical Treaty settlements, so that the offer was to be 17 percent of the real value of total settlement expenditure. The relativity clause appears to have emerged as a result of discussion between Graham and Mahuta. It seems to have been a ministerial initiative that was later endorsed by Cabinet. ${ }^{600}$ The clause ensured that if more was spent on historical settlements in the future Waikato-Tainui was still guaranteed 17 percent of the total spent on redress. This relativity mechanism gave assurance to Waikato-Tainui as the first major claim to be settled under the confines of the settlement envelope. ${ }^{601} \mathrm{Ngāi}$

\footnotetext{
59710 February 1995, 'Protestors Spit While Tainui Quietly Grabs the Cashbox," The National Business Review, 10 February 1995, 1

${ }^{598} 10$ February 1995, Protestors Spit While Tainui Quietly Grabs the Cashbox," The National Business Review, 10 February 1995 1995, 2

${ }_{599}$ Derek Fox, "The Treaty of Waikato," Mana Magazine, February-April 1995, 35.

600 Interview with Sir Douglas Graham, 15 August 2012; Fisher, "Balancing Rangatiratanga and Kawanatanga: Waikato-Tainui and Ngāi Tahu's Treaty Settlement Negotiations with the Crown," 1389.

${ }^{601}$ Waikato Deed of Settlement, 22 May 1995, clause 16.1, Attachment 9
} 
Tahu also negotiated a similar relativity clause as part of its redress some two years later.

\section{The Emergence of the Crown Apology}

One of the key aspects of the settlement for Waikato-Tainui was the Crown apology, which was incorporated into the Deed of Settlement signed by the two parties on 22 May 1995. The settlement was a full and final settlement of all of Tainui's raupatu claims. It included three main components: the return of 40,000 acres of Crown land, a Crown apology, and monetary compensation to bring the value of the settlement to $\$ 170$ million. ${ }^{602}$ Waikato-Tainui also agreed to withdraw its legal action on coal and accept that all minerals (including coal) would remain in Crown ownership. ${ }^{603}$ Initially there was some dissention within Waikato-Tainui about the way compensation was to be distributed, and whether individual hapū should benefit, rather than the wider collective. The Waikato-Tainui Trust Board worked hard to ensure that beneficiaries understood the nature of the agreement. A postal ballot was held and registered beneficiaries were able to vote for or against the proposed settlement; of those who responded 75 percent were in favour of the settlement. ${ }^{604}$ The Waikato-Raupatu Claims Settlement Act 1995 gave effect to the settlement.

The adaptability of government to the priorities of Waikato-Tainui and other claimants is signalled by the fact that the Crown apology has developed as a significant part of a deed of settlement even though it was not signalled in the Crown Proposals. The suggestion that the Crown could offer an apology to Waikato-Tainui for its historical actions emerged very early in the formal negotiations process. A former Crown official, who took part in the 'scoping negotiations' with WaikatoTainui, recalled a Tainui kuia on the Waikato-Tainui negotiating team saying that all they wanted was for the Crown to say sorry for its actions, particularly for the

\footnotetext{
${ }^{602}$ Waikato Raupatu Claims Settlement Act 1995, clause 9

${ }^{603}$ Orange, The Treaty of Waitangi, 255. Claims to the Waikato River and West Coast harbours were exempt from the settlement

${ }^{604}$ Durie, Te Māna, Te Kāwanatanga: The Politics of Māori Self-Determination, 198.
} 
raupatu of its land. ${ }^{605}$ Advice from officials to Graham, shortly after he took on the role of Treaty negotiations in May 1991, noted that while the previous Labour government had been prepared to offer generous settlements it had not been prepared to apologise for the 'sins of the past'. The memo noted that to acknowledge and apologise for past actions of the state could lead to improved relations with claimants. ${ }^{606}$ Through the negotiations process it was increasingly apparent how important an apology was for removing Waikato-Tainui's sense of grievance, and 'it was suggested therefore that the Crown should formally acknowledge the wrong done and tender a full apology. ${ }^{607}$ Representatives of Waikato-Tainui and Crown officials negotiated an agreed text setting out the historical background to Waikato-Tainui's claims, acknowledgements of the Crown, and a Crown apology. ${ }^{608}$ The resulting acknowledgements and apology were included in the Deed of Settlement, signed at Ngaruawahia on 22 May 1995 by the Māori Queen, Te Arikinui Dame Te Atairangikaahu and the Prime Minister, Jim Bolger. Several months later, in November 1995, Queen Elizabeth II assented to the Waikato Raupatu Claims Settlement Act, which gave effect to the settlement. Like much of the results of the Waikato-Tainui negotiations, the symbolism of the Crown apology was ground-breaking, creating national and international precedents. A further significant moment in the settlement process was when Queen Elizabeth read the Crown apology and signed the legislation bringing the deed of settlement into law during a state visit in 1995.

Waikato-Tainui received the first negotiated Crown apology; Ngāi Tahu followed in 1998. A Crown apology is now included as a significant component of all deeds of settlement, and has come to be seen as a key aspect to restoring the relationship between the Crown and the affected claimant group. Three smaller claims settled in 1995 and 1996 included recitals (historical background) on the claim but no apology,

\footnotetext{
${ }^{605}$ Interview with former Crown Official 1, 3 November 2014

${ }^{606} 29$ May 1991, TOWPU Memo to Minister of Justice, T 1/50, OTS archive.

${ }^{607}$ Graham, Trick or Treaty?, 74.

608 The historical component of a deed of settlement has developed to include three specific elements; an historical account, the Crown acknowledgements and the Crown apology itself. The generic term 'Crown Apology' is sometimes used to encompass all three of these elements and that is how it is used in this context. See Settlements, Ka Tika $\bar{A}$ Muri, Ka Tika $\bar{A}$ Mua: Healing the Past, Building a Future. A Guide to Treaty of Waitangi Claims and Negotiations with the Crown, 85.
} 
they were Waimakuku (wai 147), Rotoma (wai 90), and Te Maunga (wai 315). ${ }^{609}$ Since 1997 every deed of settlement, has included a Crown apology. The development of a negotiated Crown apology and associated text reflect a sense of the Crown taking responsibility for the wider context of claims. Crown apologies are now considered an essential part of a deed of settlement, and they are also incorporated in the preamble to legislation which is introduced to implement each individual settlement.

The Crown Apology represents the concept of reconciliation in what is ultimately a political process. Graham spoke of the importance of acknowledging the wrong and then apologising for it. ${ }^{610}$ The restorative justice aspect of the Crown apology can be seen in an international context. ${ }^{611}$ Over the past few decades, various societies around the world have been considering how best to address past atrocities and political 'crimes' committed by governments against their own people. There has been a growing development to repair the relationship with indigenous peoples through acts of reconciliation. For a process of reconciliation to succeed a government must be willing to bring historically damaging actions to the surface and address them in a way that satisfies both parties. This action can take a myriad of forms, as Ann Rigney identified: 'Truth commissions and inquiries, compensation settlements and state apologies have become part of the fixed repertoire of reconciliatory remembrance'. All of these are instruments used to manage 'the transition between a divisive past and new forms of co-existence. ${ }^{612}$ There is a growing body of international literature on the development of a culture of apology and the role of an apology in acknowledging past actions and damage and moving a relationship into a new phase.

Observers of the process have noted that in the negotiation of a Crown apology, it is the Crown which 'largely determines what is to be negotiated and has had greater influence over the final outcome of the historical accounts'. ${ }^{613}$ Martin Fisher pointed

\footnotetext{
${ }^{609}$ https://www.govt.nz/treaty-settlement-documents/, accessed 26 July 2014

${ }^{610}$ Interview with Sir Douglas Graham, 15 August 2012

611 See Ruti G Teitel, Transitional Justice (Oxford: Oxford University Press, 2000).

612 Anne Rigney, "Reconciliation and Remembering: (How) Does It Work?," Memory Studies 5(3) (2012): 252.

613 Julie C Bellingham, "The Office of Treaty Settlements: An Historiographical Study of the Historical Accounts, Acknowldgements and Apologies Written by the Crown, 1992 to 2003" (MA, Victoria
} 
out that both Waikato-Tainui and Ngāi Tahu expressed frustration that the Crown would not include certain details that were important to both iwi. Waikato-Tainui wanted to ensure that the apology and supporting material actually reflected its experience and was not a diluted version of events. The Crown made compromises too. Internally it sought to balance appropriate wording to describe the impact of historical actions, while also being acutely aware of the legal implications and the precedent setting nature of any wording that it agreed to with Waikato-Tainui. ${ }^{614}$ Indeed the Crown came under criticism for the level of compromise it was prepared to make. ${ }^{615}$ The resulting historical detail and Crown apology is a 'negotiated' outcome, but one that both parties need to agree to. Waikato-Tainui must have been satisfied that this was an acceptable compromise in terms of its rangatiratanga, or else it would not have been prepared to sign the deed.

The nature of the Crown apology and associated historical texts has changed significantly over the past twenty years; they are now more comprehensive and detailed. When they are combined, the Crown acknowledgements and the Crown apology to Waikato-Tainui totalled around 600 words; the apology included in the Deed of Settlement for the South Taranaki iwi of Ngāruahine included both an historical account of 22 pages and images and maps to support the written evidence. ${ }^{616}$ Likewise the Ngāi Tūhoe Deed of Settlement, signed in June 2013 is multi-faceted and comprehensive; it included background detail to the negotiation process, Crown acknowledgements and an apology, and set the intention for Tūhoe and the Crown as they entered the post-settlement phase of their relationship. This section of the Deed of Settlement, in te reo Māori and English totalled more than 90

University of Wellington, 2006), 3. For further discussion on the international context see Wethey, "The Politics of Apology: Issues Arising from State Apologies to Indigenous Peoples for Historical Injustices in Australasia and North America."

${ }_{614}$ Fisher, "Balancing Rangatiratanga and Kawanatanga: Waikato-Tainui and Ngāi Tahu's Treaty Settlement Negotiations with the Crown," 224.

${ }_{615}$ Bill Oliver, "Getting Facts on Your Side," New Zealand Books, December 1995, 15. See also Richard S Hill, "Historical 'Facts' and the Waikato Raupatu Claims Settlement Act 1995," Treaty Research Series, Treaty of Waitangi Research Unit, Stout Research Centre (2014).

${ }^{616}$ Ngaruahine Deed of Settlement of Historical Claims, 1 August 2014, http://nz01.terabyte.co.nz/ots/DocumentLibrary/Ngaruahine-DeedofSettlement.pdf., accessed 20 October 2014, 
pages. It is clear that Crown apologies increasingly reflect the priorities of the claimant groups they are offered to. ${ }^{617}$

\section{Settlement with Ngāi Tahu}

If the Waikato-Tainui settlement broke new ground for the inclusion of the relativity clause and a Crown apology, the Ngāi Tahu settlement, just two years later, was significant for the development of both cultural redress and the establishment of Te Rūnanga o Ngāi Tahu as a legal entity. The Ngāi Tahu claims were negotiated from 1991 and concluded with the signing of a deed of settlement in November 1997.

The Ngāi Tahu Claims Settlement Act 1998 implemented the settlement arrangements. Ngāi Tahu's claims focussed on the Crown purchase of large tracts of the South Island, resulting in the alienation of vast amounts of land through Crown purchase, for a paltry sum. A further result was that promised reserves were not set aside, leaving Ngāi Tahu virtually landless. The Waitangi Tribunal noted that formal complaints from $\mathrm{Ngāi}$ Tahu about the inadequacy of the reserves allocated to it had begun back in 1866. As a result, Ngāi Tahu lost access to pounamu (greenstone), and to hunting and food gathering areas (known as mahinga kai), all of which they had sought to protect under the purchase agreements. These mahinga kai resources were crucial to Ngāi Tahu and became significant in the negotiations process.

The path to settlement for Ngāi Tahu was different from that of Waikato-Tainui. While Tainui were content to negotiate directly with the Crown without first going through the Waitangi Tribunal investigation process, Ngāi Tahu preferred to have its claims heard and reported on by the Tribunal. At the time, the Ngāi Tahu inquiry claims were the most thorough claims that had been presented to the Tribunal. Over 200 Ngāi Tahu claims were presented to the Waitangi Tribunal in over two years of hearings. Due to the extensive number and nature of the claims, the inquiry generated an unprecedented level of historical investigation. ${ }^{618}$ In February 1991,

\footnotetext{
${ }^{617}$ Ngāi Tūhoe Deed of Settlement of Historical Claims, 4 June 2013, accessed 20 October 2014, http://nz01.terabyte.co.nz/ots/DocumentLibrary/TuhoeDOS.pdf

${ }^{618}$ Ward, An Unsettled History: Treaty Claims in New Zealand Today, 56.
} 
the Tribunal reported on the main elements of Ngāi Tahu's historic claims, described collectively as the "Nine Tall Trees" of Ngāi Tahu's grievances. In 1995 the Tribunal released a second report on the ancillary claims. ${ }^{619}$ Overall the Waitangi Tribunal found that the Crown had failed in its duty to Ngāi Tahu in multiple ways.

The Crown and Ngāi Tahu entered formal negotiations in September 1991. Like Waikato-Tainui, Ngāi Tahu eventually found itself constrained in negotiations by the presence of the fiscal cap. Although Ngāi Tahu maintained that the present-day value of its losses were valued at up to $\$ 17$ billion, O'Regan noted that it had never sought to claim the full value of its loss: 'we do not want to bankrupt the economy in which we wish to participate. ${ }^{620}$ Of course, to claim full recompense would have been futile. Eventually, while Ngāi Tahu were reluctant to acknowledge that the settlement envelope and the relativity aspects established by the fisheries settlement and the $\$ 170$ million Waikato-Tainui settlement, it had no choice but to agree that the Crown redress offer was going to be limited. ${ }^{621}$

Ngāi Tahu had long maintained that the return of areas of significance was a priority for it, although many of these areas were now part of the Department of Conservation Estate, and as such were not readily available to be returned as part of a Treaty settlement. ${ }^{622}$ Ngāi Tahu emphasised these non-fiscal aspects of its settlement. Through negotiations a wide range of provisions recognising the importance of cultural aspects of the Ngāi Tahu claims were developed to achieve the goal of balanced, durable settlements. As a result, the Crown recognised particular spiritual, cultural and historical associations held by Ngāi Tahu with the natural environment. The cultural redress aspects included in the Ngāi Tahu settlement, in fact, were a significant point of difference between the Ngāi Tahu and the Waikato-Tainui negotiations only two years earlier. Given Ngāi Tahu's focus on the return of areas of significance, especially mahinga kai, new protocols and legal provisions were developed through the negotiations process. These included deeds

619 Tribunal, The Ngai Tahu Report 1991 (Wai 27). (3 vols.); Ngai Tahu Ancillary Claims Report (Wai 27) (Wellington: Waitangi Tribunal, 1995).

620 "Figure Wrong - Ngai Tahu," 5.

${ }^{621}$ As noted earlier, the advice of Crown officials was that Waikato, Taranaki and Ngāi Tahu were regarded as having roughly equivalent grievances reflecting official assessments through time. ${ }_{622}$ Settlements, Crown Proposals for the Settlement of Treaty of Waitangi Claims: Detailed Proposals, 13. 
of recognition, statutory instruments, and legal mechanisms which provided recognition of sites of significance, access to specific areas, and the vesting of reserves in Ngāi Tahu. ${ }^{623}$

The Heads of Agreement between Ngāi Tahu and the Crown was signed 5 October 1996. The document was the first public signal of the approach that Ngāi Tahu and the Crown would take to settle the historical claims of the iwi in a full and final manner. It provided for an immediate on account payment of $\$ 10$ million for $\mathrm{Te}$ Rūnanga o Ngāi Tahu. Perhaps even more significantly it also provided for the vesting of all pounamu within Ngāi Tahu's rohe in Te Rūnanga o Ngāi Tahu. This was later effected through the Ngāi Tahu (Pounamu Vesting) Act 1997. ${ }^{624}$ Graham reflected that at the time it took some innovative thinking on behalf of the Crown to acknowledge that it did not need to own pounamu, and there was no impediment for it to be returned to Ngāi Tahu. ${ }^{625}$ Tūtaepatu Lagoon, in Canterbury, was also to be vested in the Rūnanga, along with a gift of $\$ 25,000$ to help restore the ecology of the lagoon's wetlands. ${ }^{626}$ Overall the 'on-account' settlement was a reflection of $\mathrm{Ngāi}$ Tahu's desire to have its kaitiakitanga (guardianship or stewardship) role recognised, and thereby expand the cultural redress aspects of its settlement as much as possible. The Heads of Agreement included a Crown apology setting out the Crown's breaches of the principles of the Treaty of Waitangi. It also set out the settlement redress amount of $\$ 170$ million, with a relativity clause, if the total settlement expenditure exceeded $\$ 1$ billion in 1994 present value terms. The heads of agreement also established a Deferred Selection Process (DSP) which allowed Ngāi Tahu to select Crown properties at market value. The iwi would also have the right of first refusal (RFR) over Crown land, when it became surplus to Crown requirements. Ngāi Tahu were able to leverage considerable financial value from this process, by purchasing Crown properties at market value and on selling at a later time. ${ }^{627}$ One of the most significant aspects of the Heads of Agreement was the

\footnotetext{
${ }^{623}$ Department of Conservation Paper, 'Ngāi Tahu Negotiations: preliminary Crown position on sites of recreational and conservation interest', September 1997

${ }_{624}^{6}$ Evening Post, 25 September 1997, The Dominion, 26 September 1997

${ }^{625}$ Interview with Sir Douglas Graham, 15 August 2012

${ }^{626}$ Ngāi Tahu Negotiating Group, "Te Karaka Special Edition: Crown Settlement Offer. Consultation Document from the Ngāi Tahu Negotiating Group," (Christchurch1997), 13.

${ }_{627}$ Fisher, "Balancing Rangatiratanga and Kawanatanga: Waikato-Tainui and Ngāi Tahu's Treaty Settlement Negotiations with the Crown," 163.
} 
development of cultural redress protocols, developed through the negotiations process, which were a way of recognising significant sites and locations within Ngāi Tahu's rohe.

Tipene O'Regan told the Ngāi Tahu beneficiaries that 'the Crown's proposal $\$ 170$ million was, in itself, simply not acceptable. ${ }^{1628}$ Therefore, the iwi looked for ways to add on to the fiscal limitation of $\$ 170$ million, O'Regan referring to these as 'boltons'. Through the process of negotiations, Ngāi Tahu and the Crown sought to develop mutually acceptable ways of re-establishing the iwi's access to key spiritual, and cultural locations, as well as to food and resources in its rohe. Ngāi Tahu, like many claimant groups, had also been excluded from decision-making (or a kaitiaki role) on environmental and conservation matters, a consequence of its alienation from its lands. These aspects of settlement which recognise spiritual, cultural and historical association that a claimant group has with the land and the natural environment became known as 'cultural redress'. They have developed to become major aspects of the contemporary Treaty settlements process. ${ }^{629}$ The Ngāi Tahu settlement was ground-breaking in its recognition of the importance of such cultural redress to claimants, defined by the Office of Treaty Settlements as reparation that meets 'the cultural rather than economic interests of the claimant group. ${ }^{630}$

The Waitangi Tribunal had found that at the time of the major land purchases made by the Crown between 1844 and 1864 the Crown failed to set aside adequate reserves for Ngāi Tahu's use. The iwi had sought to have specific areas and resources reserved to it at the time of the purchases and these were not honoured. The iwi continued to assert its interests over such areas. Given that privately owned freehold land was not available to be returned through the Treaty settlements process, it was not possible to retrieve most of the proposed reserved lands.

\footnotetext{
${ }^{628}$ Te Karaka Settlement Offer: consultation document from the Ngāi Tahu Negotiating Group: five generations of Ngāi Tahu men and women have grown old in the shadow of our tall trees, (Christchurch, 1997), 6. [emphasis in original]

${ }^{629}$ For an example of a contemporary approach to cultural redress see Ngāi Tūhoe Deed of Settlement signed on 4 June 2013. This thesis does not seek to discuss the details of the negotiations between Ngāi Tahu and the Crown. For more details on the negotiations process see Fisher, "Balancing Rangatiratanga and Kawanatanga: Waikato-Tainui and Ngāi Tahu's Treaty Settlement Negotiations with the Crown."

${ }_{630}$ Settlements, Ka Tika $\bar{A}$ Muri, Ka Tika Ā Mua: Healing the Past, Building a Future. A Guide to Treaty of Waitangi Claims and Negotiations with the Crown, 90.
} 
Instead, Ngāi Tahu focussed on the return of Crown land in its rohe, much of which was now held within the Department of Conservation estate. ${ }^{631}$ Alan Ward pointed to the 'bitter struggle waged by conservation groups to prevent the conservation estate reverting to Māori control, no matter how inequitably it was acquired by the Crown in the first place. ${ }^{1632}$ There was a great deal of concern aired in the media and to ministers of Treaty Settlements and Conservation about whether the conservation of land and species would be upheld by Māori. Conservation lobby groups emphasised the potential incompatibility of the goals of Treaty settlements and the objectives of conservation. These conservation groups were adamant that conservation of species and continued public access to conservation areas not be compromised, and many alleged that claimants were not motivated by the same goals. ${ }^{633} \mathrm{Ngāi}$ Tahu were critical of the political power that these groups had. ${ }^{634}$

Despite the limitations on much of the land which Ngāi Tahu had specific interests in, the Crown and Ngāi Tahu negotiated that the title to the farmable parts of three high country stations (Greenstone Valley, Elfin Bay and Routeburn), and access to Whenua Hou (Codfish Island) be returned. The iwi were also to receive the title to Titi (Mutton Bird) and Rarotoka (Centre Island) Islands, and the freehold title to the beds of Lake Mahinapua and Te Waihora (Lake Ellesmere). The agreement also set out details of the return of mahinga kai and nohoanga (camping areas for food gathering purposes), there were further provisions for access to defined areas adjacent to lakes and rivers for customary fishing purposes and provisions for the iwi to be involved in the management of customary fisheries. ${ }^{635}$ These new legal provisions also provided for a greater role in conservation management for Ngāi Tahu. The agreement also provided for a dedicated Ngāi Tahu member on conservation boards within the rohe. A significant aspect of the settlement was the return of the title of Aoraki (Mt Cook) to Ngāi Tahu, which was then to be gifted back

\footnotetext{
${ }^{631}$ It has always been Crown policy that freehold title is not available to be returned as part of a Treaty Settlement, therefore it is only land held by the Crown that can be considered for return as part of the settlement process.

632 Ward, An Unsettled History: Treaty Claims in New Zealand Today, 58.

${ }^{633}$ See for example 'What Price History', 5 July1997, New Zealand Listener, 26.

6349 October 1996 , 'Freeing the future from grievance', The Dominion; Fisher, "Defenders of the Environment: Third-Party Interests and Crown-Ngāi Tahu Treaty Settlement Negotiations."

63523 September 1997, Press Release, 'Crown offer to Ngai Tahu'
} 
to the nation. None of these provisions affected public rights or access to land in the conservation estate. ${ }^{636}$

The types of protocols and statutory instruments created during the Ngāi Tahu negotiations have been refined and developed further over the process of successive negotiations. The June 2013 settlement with $\mathrm{Ngāi}$ Tūhoe (Tūhoe) which included the recognition of Te Urewera National Park as a legal entity is an example of the progress of the Treaty settlement negotiation process over time. While the cogovernance arrangements negotiated in that settlement have been acknowledged as establishing a new level of recognition for Tūhoe, the foundation of this can be traced back to the Ngāi Tahu settlement. Those co-management arrangements reflect the political environment in which they were negotiated and their pioneering nature. As this chapter's analysis of the Waikato-Tainui and Ngāi Tahu negotiations shows, this shift has come about as the level of authority that the Crown has been willing to cede in Treaty settlements has shifted, and 'is now considerably more than it was in the 1990s. ${ }^{1637}$ This 'shift' has taken place in incremental steps, as each negotiation and resulting settlement has built on those that have come before.

The final Crown offer was made to Ngāi Tahu on 23 September 1997 and was then taken by the iwi negotiators to present to the $\mathrm{Nga} i \mathrm{~T}$ Tahu beneficiaries for ratification. The cultural redress aspects were described as setting 'this offer apart from any previous Treaty of Waitangi settlement' and in many cases involved 'new mechanisms and ideas that have been developed out of the negotiation process. ${ }^{638}$ The final Deed of Settlement was signed on 23 September 1997. At the end of November the Prime Minister, Jenny Shipley, other ministers and Crown officials travelled to Onuku marae on Banks Peninsula, a site chosen by Ngāi Tahu, where the Prime Minister delivered the Crown apology. ${ }^{639}$ Several hundred Ngāi Tahu welcomed the Crown one of the places its chiefs had signed the Treaty of Waitangi

\footnotetext{
${ }^{636} 19$ June 1998, 'Concern over access rule on settlement', The Dominion

${ }^{637}$ Harris, "The Changing Face of Co-Governance in New Zealand - How Are Ngāi Tahu and Ngāi Tūhoe Promoting the Interests of Their People through Power-Sharing Arrangements in Resource Management?," 168.

${ }^{638}$ Group, "Te Karaka Special Edition: Crown Settlement Offer. Consultation Document from the Ngāi Tahu Negotiating Group," 25.

${ }^{639} 30$ November 1998, 'PM says sorry to Ngai Tahu', The Dominion, The Ngāi Tahu Claims Settlement Bill was passed on 30 September 1998
} 
in 1840. Here was a very real example of policy moving from parliament to the paepae, and the symbolic conclusion to nearly 150 years of grievance. O'Regan reiterated that while the settlement represented only a fraction of Ngāi Tahu's losses it offered an economic base for the iwi to build on: 'we have negotiated a settlement that is as good as we think we can do, and our people have resolved to accept it. ${ }^{1640}$

\section{The Establishment of Te Rūnanga o Ngāi Tahu}

In 1996, during the period of negotiation Te Rūnanga o Ngāi Tahu Act was passed after strong representations during negotiations by the iwi. This legislation established Te Rūnanga o Ngāi Tahu as a corporate entity and the recognised representative of Ngāi Tahu Whanui in negotiations with the Crown. For many years Ngāi Tahu sought both to control its own management structure and to be accountable to its own people, rather than through the existing Ngāi Tahu Māori Trust Board, which was established through the Ngai Tahu Claim Settlement Act (1944) to receive compensation payments as recommended by the Native-land Claims Commission in 1921. ${ }^{641}$ Under that legislation the Trust Board as an organisation was defined and established by the Crown, and ultimately answerable to the Minister of Māori Affairs. ${ }^{642} \mathrm{Ngāi}$ Tahu sought to be recognised as a legal entity, answerable to its own members, through the introduction of the 1996 legislation. There had been challenges from several hapū within Ngāi Tahu's boundary. Three hapū, Ngāti Mamoe, Tuhuru and Waitaha 'objected to being subsumed under a corporate Ngāi Tahu structure. ${ }^{643}$ They argued that they were not part of Ngāi Tahu but were iwi in their own right and therefore did not recognise Ngāi Tahu's mandate over their rohe. ${ }^{644}$ Despite the objections the legislation was passed on 24 April 1996. The Ngāi Tahu Māori Trust Board was replaced with a new legal entity, which represented Ngāi Tahu's 18 marae-centred rūnanga, and was able to manage the settlement assets. O'Regan reflected that the

\footnotetext{
64012 June 1998 ,'Ngai Tahu defends settlement', The Dominion

641 The reports of the Native-land Claims Commission AJHR 1921 G5

642 Marr, "Crown Policy Towards Major Crown-Iwi Claim Agreements of the 1940s and 1950s: A

Preliminary Report for the Treaty of Waitangi Policy Unit."

${ }^{643}$ Ward, An Unsettled History: Treaty Claims in New Zealand Today, 59.

644 See for example The Dominion, 9 October 1996
} 
establishment of Te Rūnanga o Ngāi Tahu was a pivotal step for Ngāi Tahu to move out of a colonial mode into establishing its own destiny. ${ }^{645}$ He spoke of reinvigoration of its iwi corporate structure: 'the Ngai Tahu negotiation team's greatest single achievement was rallying the scattered runanga and forcing the Crown to recognise the tribe as a legal person in the same way any company or corporation can be a legal personality, owning assets and having official standing.' ${ }^{646}$

\section{Limitations of the Relativity Clause}

In contrast with Waikato-Tainui and Ngāi Tahu the Eastern Bay of Plenty iwi of Whakatōhea were not able to negotiate a relativity clause as part of its settlement. As has already been discussed, there had been criticism of the limitation imposed by the settlement envelope. Alan Ward was also critical of the emphasis on the big claims, such as Waikato-Tainui and Ngāi Tahu. ${ }^{647}$ It raised the question of how much leverage there was for claimants to deal with their own claims on their own terms. While there was movement in the areas of Crown apology and cultural redress, it must be acknowledged that this was somewhat limited. The settlement of Treaty of Waitangi claims is ultimately a political process, and any concessions were carefully weighed up by the Crown. The use of the relativity clause can be considered in this context.

An example of the limitation of the relativity clause emerged during the direct negotiations between the Crown and Whakatōhea. These negotiations moved with some haste, in an attempt to reach settlement agreement prior to the 12 October 1996 election, which was the first to be held under the new Mixed Member Proportional electoral system. ${ }^{648}$ There was concern that the new electoral system would result in political uncertainty for the Treaty of Waitangi Settlement process. A draft Deed of Settlement was signed between Whakatōhea and the Crown on 1 October, just days before the election. It was intended as a full and final settlement

\footnotetext{
${ }^{645}$ O'Regan, "A Ngāi Tahu Perspective on Some Treaty Questions," 95.

${ }^{646} 8$ February 2014, 'Man of Mana', Christchurch Press

${ }^{647}$ Ward, An Unsettled History: Treaty Claims in New Zealand Today, 174-5.

${ }^{648}$ The claim, wai 87, had been registered with the Waitangi Tribunal in 1989. The mandate for the Whakatōhea Negotiating Committee had been recognized by the Office of Treaty Settlements in 1995
} 
of all of Whakatōhea's grievances and included a Crown apology; some provision for deeds of recognition to conservation areas; and a role for co-management of the conservation estate; and compensation of $\$ 40$ million, which included the return of Crown and State-owned Enterprise land around Ōpōtiki. As with all such agreements, the draft Whakatōhea Deed of Settlement was conditional on ratification by Whakatōhea beneficiaries, in other words those who had identified as Whakatōhea and had been registered by the iwi. Given the timing of the signing of this particular draft deed, it also required endorsement by the incoming government.

On the day that the Deed of Settlement was initialled there was some tension evident within the iwi over the negotiated arrangements. ${ }^{649}$ In his speech at the signing, Whakatōhea Head negotiator John Delamere (who was soon to be elected as a Member of Parliament for the New Zealand First Party) expressed disappointment that a relativities clause would not be available, and that Department Conservation land was not available as part of the settlement. ${ }^{650}$ Within weeks it was reported that Whakatōhea were likely to turn down the settlement offer.

Ranginui Walker (academic, commentator) of Whakatōhea was critical that the deed of settlement was intended to settle all of the iwi's claims, not just the claims regarding confiscation. ${ }^{651}$ In July 1997, the Whakatōhea beneficiaries voted to reject the Government's settlement offer, and at the end of March 1998 the deed was formally terminated. ${ }^{652}$

While the decision of Whakatōhea not to ratify the draft agreement probably had multiple causes, one of the contributing factors was the fact that the deed did not include a relativity clause. Other claimant groups have also requested that a relativity clause be included in their settlement agreements, but the Crown has not agreed to this. Politically, the relativity clause had achieved its goal. From the Crown's perspective, there was no need to offer further relativity clauses. The substantial settlements of Waikato-Tainui and Ngāi Tahu had provided sufficient

\footnotetext{
${ }^{649} 1$ October 1996, 'Dissenters told to voice complaints on marae', The Evening Post

${ }^{650}$ The Dominion, 2 October 1996.

651 'Maori claims at crunch point'. The Independent, 12 September 1997, 14

65228 July 1997, 'Tribe's rejection 'end of the matter", The Evening Post; 13 March 1998, 'Whakatohea Deed of Settlement to be Terminated', http://beehive.govt.nz/release/whakatohea-deedsettlement-be-terminated, accessed 26 January 2015. At the beginning of 2016, the Whakatōhea claims had still not been settled.
} 
validity to the fiscal envelope to mean it became a workable policy, and iwi had no choice but to accept settlements that reflected the relative size of their claims against other claims. The relativity clauses were (and remain) a potential financial risk for the Crown - if negotiated quantum ended up being higher than estimated, there was an increased chance of triggering the relativity mechanism. Given that the initial estimation of quanta had been done in a fairly informal manner the potential for the settlement of historical claims to cost more than was anticipated would seem to be highly possible. ${ }^{653}$ In its briefing to the incoming government in 1996 the Office of Treaty Settlements noted the use of relativity clauses created 'significant ongoing risks' to government, particularly if future governments changed or removed the cap. Given this, OTS advised that government 'may wish to review the use of relativity clauses.' 654

The fiscal envelope was officially terminated in December 1996, as a result of the coalition agreement between the National Party and the New Zealand First Party following New Zealand's first general election under the Mixed Member Proportional (MMP) electoral system. This abolition was a coalition requirement of New Zealand First, whose leader, Winston Peters, had been a National Party minister, and held portfolios in the National government (including Māori Affairs), following the 1990 election. The coalition agreement stated that the 'fiscal envelope' would be terminated albeit on the basis that there was respect for the settlements already affected, which would not be reopened; the Parties confirm that the Crown will endeavour to settle claims on their merits using the settlements already affected as benchmarks; and that settlements would be fiscally responsible. ${ }^{655}$ Abolishing the fiscal envelope was, despite appearances, largely a symbolic move, as the three qualifications essentially meant that the constraints of the fiscal envelope were still in place. The 'final abolition' of the fiscal envelope concept was announced in July 2000 by Margaret Wilson, Minister of Treaty of Waitangi Negotiations in the Labour-

\footnotetext{
${ }^{653}$ An informal attempt to rank claims, referred to as the 'Richter-scale', was alleged to have been kept in Graham's safe.

${ }_{654}$ Office of Treaty Settlements, "Briefing to the Incoming Government," (Wellington, 1996), 13.

655 '1996 Coalition Agreement between New Zealand First and The National Party of New Zealand', 11 December 1996, Schedule A; 18 December 1996 'Lifting of treaty cap largely symbolic - Graham', The Dominion; 12 September 1997, 'Treaty of Waitangi claims reach a turning point', The Independent, 14.
} 
Alliance government. ${ }^{656}$ Again, this was another symbolic move. Wilson announced that no future settlements would include a relativity clause, but that the existing benchmarks for claims would remain. Moreover, once again previous settlements would be used as benchmarks for future settlements. In reality, as long as WaikatoTainui and Ngāi Tahu settlements retained their relativity clauses, there was a check on any future settlements (and this continues to be so).

The Waikato-Tainui and Ngāi Tahu relativity clauses would have been triggered in 2013, following the initialling of the Ngāi Tūhoe Deed of Settlement. ${ }^{657}$ Christopher Finlayson, Minister for Treaty of Waitangi Negotiations, was reserved about discussing when exactly the relativity clauses would be activated or how much compensation would be due to the groups affected. In July 2012 he told the Māori Affairs select committee: 'I think I said last year that it [relativity clause] would be triggered very soon and that remains the case...We are talking to those iwi and I wouldn't want to disclose too much, if anything, quite frankly, about what we are talking about'. ${ }^{658}$ It was reported that Waikato-Tainui and Ngāi Tahu would have been entitled to approximately $\$ 56$ million based on the Tūhoe settlement of $\$ 170$ million, but it was not officially confirmed how much had been paid out for the relativity clauses. ${ }^{659}$

\section{The Progress of Settlements}

Ten years after the establishment of the Treaty of Waitangi Policy Unit and the tentative discussions that led to the Waikato-Tainui settlement, a paper to the Cabinet Strategy Committee reported that 'good progress has been made in the

\footnotetext{
${ }^{656}$ Margaret Wilson, 'New Principles to guide the settlement of historical Treaty claims', 20 July 2000, http://www.beehive.govt.nz/node/7976 accessed 7 March 2013; 20 July 2000, '\$1 billion limit on treaty settlements abolished', New Zealand Herald, http://www.nzherald.co.nz/nz/news/article.cfm?c id=1\&objectid=144713, accessed 7 March 2013 ${ }^{657} \mathrm{It}$ is following the initialing of the Deed of Settlement that the settlement amount is deducted from the Vote treaty budget.

65818 July 2012, Christopher Finlayson, Minister for Treaty of Waitangi Negotiations, '2012/13 Estimates for Vote Treaty Negotiations: Report of Māori Affairs Committee 659 Tribes due to receive 'top ups', 12 September 2012, http://www.stuff.co.nz/national/politics/7662193/Tribes-due-to-receive-top-ups, accessed 20 July 2015
} 
settlement of historical Treaty claims in recent years. ${ }^{1600}$ Three barriers impeding the progress of settling claims were identified: difficulties associated with achieving and maintaining iwi mandates; most outstanding claims required further research or were still being heard by the Waitangi Tribunal; a Crown position had not yet been formulated on key areas such as the impact and operation of the 'Native land laws' and claims to rivers, lakes and geothermal resources. ${ }^{661}$ The Crown had increasingly stated its preference to negotiate comprehensive iwi-level settlements; rather than piecemeal aspects of a claim. Over time this approach has modified further and now the Crown has a preference for negotiating and settling with 'large natural groupings'. ${ }^{662}$

The government, led by Graham, promoted the process of direct negotiations (without the need to go through a Waitangi Tribunal inquiry), as a quicker, more effective route to resolving historical claims. By this time, greater numbers of claimant groups were entering the formal negotiations process. Ngāti Awa, of Eastern Bay of Plenty were in formal negotiations with the Crown. ${ }^{663}$ And in November 1996 the Crown approved deeds of mandate from Ngati Tama, Ngati Mutunga and Ngati Maru, and in March 1997 the mandate of Ngarūahine iwi and formal negotiations began a short time later. ${ }^{664}$ The Waitangi Tribunal inquiry process was a relatively slow procedure. By 1996 over 522 claims had been registered with the Tribunal, but only 56 reports had been issued. ${ }^{665}$ Graham also reasoned that the process of direct negotiations was more cost effective than the expense of a Waitangi Tribunal; 'If we are satisfied that the grievance has been

\footnotetext{
${ }^{660} 20$ November 1998 Cabinet Strategy Committee, STR (98) 302,

${ }^{661}$ Cabinet Strategy Committee, STR (98) 302, 20.11.1998, para b

${ }^{662}$ Office of Treaty Settlements, Ka Tika A Muri, Ka Tika $\bar{A}$ Mua: Healing the Past, Building a Future. A Guide to Treaty of Waitangi Claims and Negotiations with the Crown, 39.; Robert Joseph, "Unsettling Treaty Settlements: Contemporary Māori Identity and Representation Challenges," in Treaty of Waitangi Settlements, ed. Nicola R Wheen and Janine Hayward (Wellington: Bridget Williams Books 2012).

${ }^{663}$ They were offered a $\$ 42.3$ million package in December 1998, Evening Post, 22 December 1998

${ }^{664}$ Minister in Charge of Treaty of Waitangi Negotiations, Press release, 10 March 1997; The Dominion, 24 June 1998

${ }^{665}$ It should be noted that some of the claims registered and some of the reports related to contemporary, rather than historical claims. There was no distinction between historical and contemporary claims when they were registered with the Waitangi Tribunal.
} 
established...I see no need to rush off and spend millions with the Waitangi Tribunal.'666

The speed and cost aspect was just one part of the political motivation for privileging direct negotiations over the Tribunal process. The growing Crown preference for direct negotiations was interpreted by some as undermining the influence of the Tribunal. The Crown had no control over its priorities or the findings, which had been the cause of some unease among ministers and some government officials. There had long been concern that the independent nature of the Tribunal (which gave it credibility with claimants) was also a risk, politically. Between 1985 and the year 2000 the Waitangi Tribunal released 30 major reports, and many broke new ground in their historical analysis of government-Māori interaction. The findings of the Waitangi Tribunal in relation to Turangi, Taranaki and Muriwhenua were met with scepticism and at times hostility from politicians and the mainstream press. ${ }^{667}$

\section{In August 1997 The Sunday Star Times newspaper ran a headline 'Waitangi} Fatigue' - what has been achieved so far and when will it end?'668 Graham claimed the settlement process was at a turning point, and called for tolerance from nonMāori, arguing that there would be an end to the process if Māori were allowed to put their grievances behind them. ${ }^{669}$ He recognised that some were growing weary of the settlement process as, apparently, were some Māori leaders, such as Robert Mahuta and Graham Latimer. A substantial number of registered claims had not yet been heard by the Waitangi Tribunal or made any progress with the direct negotiations process. ${ }^{670}$ There had been some expectation that the Rangahaua Whanui research programme would short-cut the process to settlement for some claims. However, in reality this did not happen. There was concern that the claims process was 'lingering'; Alan Ward felt that New Zealand history risked becoming a permanent 'bleeding sore' unless all historical Treaty of Waitangi claims were

\footnotetext{
${ }^{666}$ Graham, 'The race relations minefield', Evening Standard, 23.8.1997

667 This thesis does not seek to provide a précis of the Waitangi Tribunal's inquires and findings during this period. For further information see Waitangi Tribunal, The Turangi Township Report (Wai 84) (Wellington: Waitangi Tribunal, 1995).; The Taranaki Report: Kaupapa Tuatahi, Wai 143.; Muriwhenua Land Report (Wai 45).

668 'Waitangi Fatigue', The Sunday Star Times, 24 August 1997

6692 September 1997, 'National party conference', The Dominion

67023 September 1997, 'The race relations minefield', Evening Standard
} 
addressed. ${ }^{671}$ In March 1998 it was reported that more than half the country, 54 percent, considered Treaty of Waitangi settlements had been 'too generous' (even though there had been very few to this point). A New Zealand Herald survey reported fewer than 30 per cent of respondents believed the settlements were 'about right'. ${ }^{672}$ Again, this demonstrates the inherent tensions of the settlements process; although the process of direct negotiations sped up the resolution of historical grievances, it was not universally popular. Yet successive governments considered that it was necessary to give priority to the settlement of historical Treaty grievances.

\section{Chapter Conclusion}

The years 1996 to 1998 were highly significant in the relatively new process of settling historical Treaty of Waitangi Claims. During this time the policies which came to govern the process emerged from the confines of government departments and the Cabinet table out to the areas where those grievances had been experienced, lived and remembered. It was in this period that theory or policy met practical application, and was modified in key respects.

Richard Hill argued that most claims, whether explicitly referred to or not 'were about rangatiratanga'. ${ }^{673}$ Through the settlements process Māori sought ways to secure Crown respect for their rangatiratanga. There was always an inherent tension: any self-determination or autonomy gained from the Crown was always limited, as the government refused any recognition of rangatiratanga arrangements that might impinge upon Crown prerogatives. ${ }^{674}$ Yet, over time, settlements have built on those which have come before, and by incremental steps progress towards rangatiratanga, albeit still within Crown parameters. The first major settlement, that of WaikatoTainui in 1995, included a Crown apology. Requested by Waikato-Tainui, and negotiated with the Crown, the apology became a significant aspect of its settlement. Since then the Crown apology and accompanying texts of historical

\footnotetext{
${ }^{671} 23$ September 1998, 'Treaty claims could become 'bleeding sore', The Evening Post

${ }^{672} 6$ January 1998, 'Treaty Deals too lavish, says poll', The Evening Post; see also Morrow, Changing Times: New Zealand since 1945, 380.

${ }^{673}$ Hill, Maori and the State: Crown-Maori Relations in New Zealand/Aotearoa, 1950-2000, 260.

${ }^{674}$ Hill, Maori and the State, 261.
} 
background and Crown acknowledgement, have been recognised as a significant aspect of the settlement between the Crown and a claimant group. Likewise the Ngāi Tahu settlement of 1998 included provisions for significant cultural redress, including new statutory instruments or associated rights over Crown assets. Neither of these aspects of a settlement were provided for in the policies developed for the Crown Proposals, having been developed through the process of negotiation between the Crown and a claimant group.

In tracing these significant aspects of specific settlements, this chapter contends that the early Deeds of Settlement, particularly those signed with Waikato-Tainui and Ngāi Tahu, provided a platform from which other groups were able to adopt and build on: each negotiation incrementally builds on what has come before. This may prove to be one of the most significant legacies of the Treaty settlements process in this pioneering phase. Likewise, the cultural redress aspects developed in the negotiations between $\mathrm{Ngāi}$ Tahu and the Crown were enhanced further in later deeds of settlement. ${ }^{675}$ The cultural redress aspects were historically significant to Ngāi Tahu. According to Ngāi Tahu lead negotiator O'Regan they were also a way of Ngāi Tahu leveraging more for its settlement, within the quantum agreed for the Tainui settlement of 1995, government policy being predicated on the need to find some benchmark between quanta.

The base financial parameters had already been established by the Waikato-Tainui settlement, which itself paralleled that of the fisheries settlement. Although O'Regan had argued against relativities between settlements, as tribal resources and properties had not been of equal proportion in the first place, it became clear, as negotiations continued, that Ngāi Tahu were not going to be able to negotiate a higher quantum than the $\$ 170$ million that had been allocated to Waikato-Tainui. ${ }^{676}$ The Crown had already acknowledged the seriousness of any claim including raupatu, the waging of war in Waikato and the resulting loss of life, which the Waikato-Tainui claim clearly did. These events were considered to be at the highest level of Crown culpability and compensation was to reflect this. Eventually O'Regan

\footnotetext{
${ }^{675}$ This was possibly as the total amount spent of Treaty settlements grew closer to the $\$ 1$ billion cap set in 1992. This has lead to a significant break-through as now the Whanganui River and the former Te Urewera National Park have been identified as being legal entities.

${ }^{676}$ O'Regan, "A Ngāi Tahu Perspective on Some Treaty Questions," 89.
} 
and Ngāi Tahu had to concede this point if they wanted to make progress with the negotiations.

Neither the Crown apology nor extensive cultural redress were part of draft proposals presented by the Crown in December 1994, but rather emerged in the space of the two major pioneering iwi groups negotiating with the Crown. These became a crucial element in ongoing negotiations; perhaps their strength in adding to the durability of settlements reflects their organic development though iwi-based demands, as opposed to the Crown-generated polices which later fell by the wayside. 


\section{CONCLUSION}

The Treaty is moving in as surely as the tide...You know, when we stand at the foreshore, we do not always see the movement of the tide. We see no more than the regular breaking of the waves, as if no painful inch is gained. But look back to the creeks and inlets. There, silently, it is plain to see the tide running at full flow. ${ }^{677}$

Treaty of Waitangi Settlements processes have developed significantly over the past twenty-five years. This thesis is a study of the various ways the Crown approached the resolution of historical Treaty grievances in the decade 1988-1998. The Treaty settlement process emerged as the Crown's response to historical breaches of Article Two of the Treaty, resulting from a combination of factors including political protest, pressure from Māori and other sectors of society, the Māori renaissance, an increased acknowledgement of the role of the Treaty in New Zealand society, and the establishment of the Waitangi Tribunal. This research examines key primary sources, such as Cabinet papers, and internal files of the Treaty of Waitangi Policy Unit and the Office of Treaty Settlements not previously accessed. It also builds on the work of previous scholarship and is an example of the Crown acting to accommodate Māori when Māori led action threatened the status quo. ${ }^{678}$ The outcome in this case, seeks to address and resolve historical Crown breaches of the Treaty of Waitangi, provide redress, and among other things, offer an official apology for historical Crown actions.

By 1988 the Treaty of Waitangi had risen to a position of prominence in New Zealand. The Crown had begun to take responsibility for ensuring that the Treaty was considered in relation to the implementation of policy and legislation. In 1986, under the fourth Labour government it had been agreed that any legislation referred to Cabinet should consider its implications in relation to the principles of the Treaty

\footnotetext{
677 This observation is from Edward Taihakurei Durie, first Waitangi Tribunal presiding Chair, in 1989, noting the progress of the Treaty to that point. It is also a fitting image for the period covered in this thesis. Edward Taihakurei Durie, "Waitangi 6 February 1989," in The Treaty of Waitangi Companion: Māori and Pākehā from Tasman to Today (Auckland: Auckland University Press, 2010), 361.

${ }^{678}$ See Durie, Te Māna, Te Kāwanatanga: The Politics of Māori Self-Determination; Sharp, Justice and the Māori: The Philosophy and Practice of Māori Claims in New Zealand since the 1970s (Second Edition); Hill, Maori and the State: Crown-Maori Relations in New Zealand/Aotearoa, 19502000.
} 
of Waitangi. ${ }^{679}$ The Waitangi Tribunal was beginning to inquire into and report on Māori claims to historical acts or omissions by the Crown, and reports into Waiheke Island and Orakei were considered ground-breaking, in part for tracing historical Treaty breaches and making recommendations to government to address them in the present. ${ }^{600}$ By this time the Court of Appeal had made its significant finding on the State-owned Enterprise or 'Lands case'. The legacy of the 'Lands case' was the protection of State-owned Enterprise land that may have been subject to Waitangi Tribunal claims, resulting in the Treaty of Waitangi (State Enterprises) Act 1988 and a clear articulation of the principles of the Treaty in contemporary New Zealand.

Late in 1988, the Treaty of Waitangi Policy Unit (TOWPU) was established within the Department of Justice to provide coordination on Treaty issues across different government departments. When it became operational in 1989, TOWPU was soon called upon to extend its initial brief. Within a short time, it was decided that TOWPU would also take on the role of leading the negotiating on behalf of the Crown to settle historical claims, commencing with the scoping negotiations with Waikato-Tainui.

The foundation process to address and resolve historical claims through a process of direct-negotiation was established by the fourth Labour government under Prime Minister Geoffrey Palmer, who sought to return these issues from the courtroom into the political arena. The process was still relatively provisional, without a clear understanding of the extent of historical grievances. By the 1990 election the Treaty settlement process had support from both the Labour and the National Parties. The incoming National government acknowledged that genuine grievances needed to be addressed, and undertook to settle as many as possible by the end of the decade. This in itself was significant. Such support across the political spectrum is an example of the Crown shifting to accommodate pressure from Māori. The resulting process was essentially a political one, established through policy, and it remains so.

For the remaining period covered by this study National remained the dominant party holding office, and Doug Graham's retention of his role as the Minister in

\footnotetext{
67923 June 1986, 'Treaty of Waitangi: Implications of Recognition', CM 86/22/7

680 Tribunal, Report of the Waitangi Tribunal on the Waiheke Island Claim (Wai 10).;Report of the Waitangi Tribunal on the Orakei Report (Wai 9).
} 
Charge of Treaty of Waitangi Settlements from 1991 until 1998 gave the process some continuity. The National government continued to engage in negotiation with Waikato-Tainui, and commenced negotiations with $\mathrm{Ngāi}$ Tahu (after the release of the Waitangi Tribunal report). Parallel with these formal negotiations, the Crown developed the Crown Proposals, a comprehensive series of draft policies designed to establish a clear process for negotiating and settling historical claims. When the policies of the Crown Proposals were released for consultation in December 1994, the settlement envelope of $\$ 1$ billion (the fund from which all historical claims would be settled) was introduced on a non-negotiable basis. ${ }^{681}$ There was significant backlash from Māori and others about the fact that the settlement envelope was not open for negotiations, and it was too limited an amount of money to compensate for such a significant number of claims. The inclusion of the settlement envelope and its $\$ 1$ billion cap was a public relations disaster. Officials from the Office of Treaty Settlements had advised against combining the announcement of a non-negotiable dollar amount to settle all historical claims at the same time as announcing a series of policy proposals that feedback was sought on.

A further significant flaw in the process emerged from the consultation process itself. Māori were invited to provide feedback to the draft policies, either through regional hui or through written submissions. Feedback from Māori tended to focus on the extent to which the Crown had developed policies in a vacuum, without any input from the Treaty partner. The Crown Law Office, moreover, had earlier advised that if the government were to engage in a process of consultation it must, keep an open mind, allow for sufficient time, and take the views of Māori into account when finalising any policy position. ${ }^{682}$ As has been demonstrated, this was not done and despite the submissions and feedback the majority of those draft policies remained in place.

It took some time for the ongoing impact of grievances and an inherited sense of loss that many Māori experienced to be appreciated by all Crown officials and

\footnotetext{
${ }^{681}$ Settlements, Crown Proposals for the Settlement of Treaty of Waitangi Claims: Detailed Proposals.

68229 June 1994, Treaty of Waitangi Settlement Policies: Consultation with Maori and the Wider public, CSC (94) M 21/1
} 
ministers. ${ }^{683}$ Through the negotiations process Waikato-Tainui were able to convey to the Crown the ongoing impact of raupatu which had occurred in the 1860s, and in particular to the significance of the alienation from its land. Waikato-Tainui, Ngāi Tahu and other iwi were concerned that Crown land was still being alienated even while negotiations were going on. As a result the Crown established a range of land-banks, including the protection mechanism and claim specific land-banks, as a way of retaining Crown land for return, as part of a settlement.

The influence that Māori were able to exert over the establishment, early development and bedding-in of the Treaty claims settlement process was limited at times. Yet modification did occur, particularly outside the limits of financial redress, in the areas of the Crown Apology and cultural redress, through individual claimant groups engaging with the Crown in the negotiation process. The Crown apology is an example of this. Crown apologies, which are a significant part of any Settlement, did not emerge out of policy or as a result of a Cabinet paper or the response of Crown officials to the situations but came from Maori themselves. The first Crown apology was negotiated as part of the Waikato-Tainui settlement in 1995. Since that time the negotiated apology has become a significant aspect of settlements. A significant aspect, when considering theories of reconciliation and historical justice, is the notion that an apology must also be accepted, not simply offered. An example of this was in August 2014, when Tamati Kruger lead negotiator for Ngāi Tūhoe accepted the Crown apology of behalf of the iwi, signifying the role of the apology as an instrument for reconciliation. ${ }^{684}$

This thesis argues that the development of cultural redress has followed a similar route to that of the Crown apology. As has been discussed, the return of sites of significance first emerged as a key component of the Ngāi Tahu negotiations. One key element of this was the return of pounamu to Ngāi Tahu during the negotiations process. Further cultural redress provisions were negotiated in the course of the Ngāi Tahu negotiations, particularly historically and culturally significant sites, such

\footnotetext{
${ }^{683}$ Graham, Trick or Treaty?, 72.

${ }^{684}$ This took place on 22 August 2014, when a group of Crown representatives were welcomed into heartland Tūhoe territory at Taneatua to take part in a 'Settlement Day' ceremony to mark the passing of the Tūhoe Treaty settlement legislation.
} 
as food gathering areas and camping reserves. All of which were intended to reconnect Ngāi Tahu with its traditional environment.

The approach has been modified over time as a result of negotiation between individual claimant groups and the Crown. Much of this innovation has emerged as a result of one on one negotiations between the Crown and an individual claimant group. The process has continued to evolve, with the conclusion of several significant claims. The early settlements, such as those of Waikato-Tainui and Ngāi Tahu have provided a platform other groups have been able to adapt and build on. In this way, each process of negotiation has incrementally built on what has come before. The level of 'authority that the Crown has been willing to cede in Treaty settlements has shifted, and is now considerably more than it was in the 1990s. ${ }^{, 65}$ The Ngāi Tūhoe settlement of 2013, is an example of progress made on these issues over time; Te Urewera (formerly Te Urewera National Park) is now recognised as a legal entity. ${ }^{686}$ While the co-governance arrangements negotiated in this settlement have been acknowledged as establishing a new level of recognition for Tūhoe, the foundation of this can be traced back to the Ngāi Tahu settlement. Likewise the Whanganui River, New Zealand's longest navigable river was recognised, in its entirety (from the mountain to the sea and all its tributaries) as a legal entity, in the Deed of settlement signed in August 2014. ${ }^{687}$

As I finish, I am cognisant that issues of Crown consultation with Māori have again come to the fore. There are two such issues dominating the headlines: the signing of the Trans-Pacific Partnership Agreement (TPPA) and a draft report issued by the Waitangi Tribunal. The TPPA signing in Auckland, which took place just days before Waitangi Day, led to questions about the impact of the Agreement on Māori and Treaty rights. There had been no formal consultation with Māori (nor indeed the New Zealand public as a whole) about how their rights would be affected by the

\footnotetext{
${ }^{685}$ Harris, "The Changing Face of Co-Governance in New Zealand - How Are Ngāi Tahu and Ngāi Tūhoe Promoting the Interests of Their People through Power-Sharing Arrangements in Resource Management?," 168.

${ }^{686}$ Te Urewera Act 2014; Higgins, "Te Wharehou O Tūhoe: The House That 'We' Built," 10.

${ }^{687}$ Whanganui iwi and the Crown, 'Ruruku Whakatupua te Mana o te iwi o Whanganui' 5 August 2014, https://www.govt.nz/treaty-settlement-documents/whanganui-iwi/, accessed 15 September 2015
} 
Agreement. ${ }^{688}$ On the same day, 5 February 2016, the Waitangi Tribunal issued a draft report, on 'initiation, consultation and consent' in relation to the proposed reforms to the Te Ture Whenua Māori Act 1993.689 The Tribunal was critical of the Crown's process. But Treaty Negotiations Minister Chris Finlayson rejected the draft report, saying that there had been 'well over 100 consultation hui' on the Bill. ${ }^{690}$ These are further examples of the Treaty and its principles still being navigated, by the Treaty partners, in the present day.

The claims resolutions process has come to dominate the Crown-Māori dialogue over the past 25 years. The issues are complex and there is by no means unanimous support for the Crown approach by either Māori, or the rest of the population. Claimants recognise that engaging with the Crown to settle their claims requires compromise. ${ }^{691}$ For example, the true extent of loss of lands can not be replaced or compensated for in twentieth century New Zealand, and iwi who engage in the negotiations process acknowledge this. However for the most part, Māori are also motivated to achieve settlements and many iwi have engaged, and continue to engage, in the process.

This thesis has examined the factors, fundamentally political in nature, which contributed to the development of Crown policy in the crucial decade of 1988-1998. The process and the outcome is often recognised by Māori and Pākehā leaders, scholars and commentators as being world-leading. ${ }^{692}$ During this period of rapid policy development the Treaty settlements process transitioned from ad-hoc development of policies and arrangements into an entrenched system, yet one that

\footnotetext{
${ }^{688}$ Claire Charters Carwyn Jones, Andrew Erueti, Jane Kelsey, "Expert Paper \#3 Māori Rights, Te Tiriti O Waitangi and the Trans-Pacific Partnership Agreement " TPP Legal.files.wordpress.com 20 January 2016.; Carwyn Jones, 'The TPPA and the Treaty', 3 February 2016, https://www.victoria.ac.nz/news/2016/02/the-tppa-and-the-treaty-2, accessed 9 February 2016 ${ }^{689}$ Waitangi Tribunal, Initiation, Consultation, and Consent Chapter 3 of Report into Claims Concerning Proposed Reforms to Te Ture Whenua Maori Act 1993: Pre-Publication Version, Wai 2478 (Wellington: Waitangi Tribunal, 2016). This report was in fact a draft chapter of the lager report into reforms to Te Ture Whenua Māori Act 1993 due to be released a few weeks later. Its release was prompted by the government announcement of another round of 'informational hui' due to begin on 9 February 2016.

6902 February 2016, 'Consultation on Māori land law 'nonsense", http://www.radionz.co.nz/news/national/206039/consultation-on-maori-land-law-'nonsense', accessed 9 February 2016 ${ }^{691}$ CFRT, "Maori Experiences of the Direct Negotiation Process," 51.

692 Justice Joseph Williams, "Landmarks: 40 Years of the Treaty of Waitangi Act 1975, Presentation," (Victoria University of Wellington, 12 October 2015).
} 
was flexible enough to change in the course of negotiations with new claimant groups. 


\section{SELECT BIBLIOGRAPHY}

\section{Primary Sources}

\section{Archives}

Treaty of Waitangi Policy Unit [hereafter TOWPU] files, policy files 1988-1994

TOWPU files, settlement policy, Treaty settlement proposals 1992-1994

Office of Treaty Settlements [hereafter OTS], policy files 1995-1998

OTS files, Settlement policy, Treaty settlement proposals 1995-1997

OTS files, consultation Treaty settlement 1995-1997

\section{Interviews}

Former Crown Official 1, 3 November 2014

Former Crown Official 2, 25 September 2012

Right Honourable Sir Douglas Graham (former Minister in Charge of Treaty of Waitangi Negotiations), 15 August 2012

Right Honourable Sir Geoffrey Palmer (former Minister of Justice and Prime Minister), 27 February 2012

\section{Legislation}

Crown Forest Assests Act 1989

Maori Affairs Amendment Act 1967

Maori Fisheries Act 1989

New Zealand Settlements Act 1863

Ngaitahu Claim Settlement Act 1944

Ngāi Tahu Claims Settlement Act 1998

Ngai Tahu (Pounamu Vesting) Act 1997

State-Owned Enterprises Act 1986 
Taranaki Maori Claims Settlement Act 1944

Te Runanga o Ngai Tahu Act 1996

Treaty of Waitangi Act 1975

Treaty of Waitangi (Fisheries Claims) Settlement Act 1992

Tūhoe Claims Settlement Act 2014

Waikato Raupatu Claims Settlement Act 1995

\section{Litigation}

New Zealand Maori Council V Attorney-General[1987] 1 NZLR 641

New Zealand Maori Council V Attorney-General[1989] 2 NZLR 142

Tainui Maori Trust Board V Attorney-General [1989] 2 NZLR 513

\section{Newspapers and Periodicals}

The Dominion (Wellington)

Evening Post (Wellington)

Kia Hiwa Ra: National Maori Newspaper

Mana Magazine

Māori Land Law

Metro Magazine

New Zealand Herald

North and South Magazine

Sunday Star Times

Te Karaka

The Listener

The National Business Review

Treaty Times 


\section{Official documents and Government publications}

Appendices to the Journals of the House of Representatives (AJHR)

Crown Forestry Rental Trust. "Maori Experiences of the Direct Negotiation Process." Wellington: Crown Forestry Rental Trust, 2003.

Department of Justice. "Department of Justice Annual Report.", year ended 30 June 1995.

Hill, Richard.S. "Enthroning "Justice above Might"?: The Sim Commission, Tainui and the Crown." Treaty of Waitangi Policy Unit [hereafter TOWPU], Department of Justice, Wellington, 1989.

_. "Settlements of Major Maori Claims in the 1940s: A Preliminary Historical Investigation. The Ngai Tahu Grievance and Its Ramifications." TOWPU, 1989.

Marr, Cathy, "Crown Policy Towards Major Crown/Iwi Agreements in the 1940s and 1950s." Wellington, TOWPU, 1990.

. "An Overview History of the Taranaki Confiscation Claim 1920s-1980s:

From the Sim Commission to the Submission of Taranaki Claims to the Waitangi Tribunal, Wai 143." Wellington: Waitangi Tribunal, 1993.

Office of Treaty Settlements, "Briefing to the Incoming Government." Wellington, 1996.

. Crown Proposals for the Settlement of Treaty of Waitangi Claims:

Consultation with Maori. Wellington: Office of Treaty Settlements [hereafter OTS], Department of Justice, 1994.

- Crown Proposals for the Settlement of Treaty of Waitangi Claims: Detailed Proposals. Wellington: OTS, Department of Justice, 1994.

- Crown Proposals for the Settlement of Treaty of Waitangi Claims: Summary. Wellington: OTS, Department of Justice, 1994

_. Ka Tika Ā Muri, Ka Tika Ā Mua: Healing the Past, Building a Future. A Guide to Treaty of Waitangi Claims and Negotiations with the Crown. Wellington, OTS, 2015.

.."Policy Papers for Crown Proposals for the Settlement of Treaty of Waitangi Claims", released 3 March 1995

_. "Quarterly Report 1 July 2015 - 30 September 2015 ".

_. "Report of Submissions: Crown Proposals for the Treaty of Waitangi Claims." Wellington: OTS, Department of Justice, 1995. 
."Treaty of Waitangi Policy Unit Ministerial Briefing Papers on Crown

Proposals for the Settlement of Treaty of Waitangi Claims", released on 31 March 1995.

- Treaty of Waitangi Claims - Direct Negotiation Process. A Booklet Produced by the Office of Treaty Settlements 1997. Wellington: OTS, Ministry for Justice, 1997.

The Treaty of Waitangi Policy Unit for the Crown Task Force on Treaty of Waitangi Issues. The Direct Negotiation of Maori Claims: An Information Booklet. Wellington: Department of Justice, 1990.

- Principles for Crown Action on the Treaty of Waitangi. Wellington:

Department of Justice, 1989.

The Treasury. "Treasury Advice on the Crown Proposals for the Settlement of Treaty of Waitangi Claims", released 3 March 1995

. "Government Management: Brief to the Incoming Government 1987, Vol.1." Wellington: The Treasury, 1987.

Waitangi Tribunal. He Whakaputanga Me Te Tiriti - the Declaration and the Treaty: The Report on Stage 1 of the Te Paparahi O Te Raki Inquiry. Wellington: Waitangi Tribunal, 2014.

- He Kura Whenua Ka Rokohanga: Report on Claims about the Reform of Te Ture Whenua Māori Act 1993, Pre-Publication Version (Wai 2478).

Wellington: Waitangi Tribunal, 2016.

—. Muriwhenua Land Report (Wai 45). Wellington: Waitangi Tribunal, 1997.

—. Ngai Tahu Ancillary Claims Report (Wai 27). Wellington: Waitangi Tribunal, 1995.

_. The Ngai Tahu Claim: Supplementary Report on Legal Personality. Wellington: Waitangi Tribunal, 1991.

—. The Ngai Tahu Report 1991 (Wai 27). Wellington: Waitangi Tribunal, 1991.

. Report of the Waitangi Tribunal Claims Concerning the Allocation of Radio Frequencies (Wai 26, Wai 150). Wellington: Waitangi Tribunal, 1990.

- Report of the Waitangi Tribunal on a Claim by J.P Hawke and Others of Ngati Whatua Concerning the Fisheries Regulations, (Wai 1). Wellington Waitangi Tribunal, 1978.

. Report of the Waitangi Tribunal on the Kaituna River Claim, (Wai 4).

Wellington: Waitangi Tribunal, 1984.

- Report of the Waitangi Tribunal on the Manukau Claim, (Wai 8). Wellington: Waitangi Tribunal, 1985. 
Report of the Waitangi Tribunal on the Motunui-Waitara Claim, (Wai 6).

Wellington: Waitangi Tribunal, 1983.

. Report of the Waitangi Tribunal on the Muriwhenua Fishing Claim (Wai 22).

Wellington: Waitangi Tribunal, 1988.

. Report of the Waitangi Tribunal on the Orakei Report (Wai 9). Wellington:

Waitangi Tribunal, 1987.

Report of the Waitangi Tribunal on the Te Reo Maori Claim (Wai 11).

Wellington: Waitangi Tribunal, 1986.

Report of the Waitangi Tribunal on the Waiheke Island Claim (Wai 10).

Wellington: Waitangi Tribunal, 1987.

- The Taranaki Report: Kaupapa Tuatahi, (Wai 143). Wellington: Waitangi

Tribunal, 1996.

—. Te Roroa Report (Wai 38). Wellington: Waitangi Tribunal, 1992.

- The Turangi Township Report (Wai 84). Wellington: Waitangi Tribunal, 1995.

\section{Secondary Sources}

\section{Articles, books, theses}

Aimer, Peter and Jack Vowles. Voters' Vengeance: The 1990 Election in New Zealand and the Fate of the Fourth Labour Government, Auckland: Auckland University Press, 1993.

Anderson, Atholl, Judith Binney, Aroha Harris. Tangata Whenua, Wellington: Bridget Williams Books, 2015.

Awatere, Donna. Maori Sovereignty, Auckland: Broadsheet, 1984.

Bargh, M. "Maori Development and Neoliberalism." in M. Bargh (ed.), Resistance: An Indigenous Response to Neoliberalism, Wellington: Huia, 2007.

Bargh, Maria. "The Post-Settlement World (So Far): Impacts for Māori." in Nicola R. Wheen and Janine Hayward (eds.), Treaty of Waitangi Settlements, Wellington: Bridget Williams Books, 2012.

Barkan, Elazar. The Guilt of Nations: Restitution and Negotiating Historical Injustices, New York: W W Norton and Co., 2000 
Belgrave, Michael. Historical frictions: Māori claims and reinvented histories, Auckland: Auckland university Press, 2005.

."Negotiations and Settlements." in Nicola R Wheen and Janine Hayward (eds.), Treaty of Waitangi Settlements, Wellington: Bridget Williams Books, 2012.

. "Something Borrowed, Something New: History and the Waitangi Tribunal." in Bronwyn Dalley and Jock Phillips (eds.), Going Public: The Changing Face of New Zealand History, Auckland: Auckland University Press, 2001.

Belich, James. Paradise Reforged: A History of the New Zealanders from the 1880s to the Year 2000, Auckland: Penguin Books (NZ) Ltd, 2001.

- Making Peoples: A History of New Zealanders from Polynesian settlement to the end of the nineteenth century, North Shore: Penguin, 2007

Bell, Rachael, 'Texts and Translations,' Ruth Ross and the Treaty of Waitangi.' New Zealand Journal of History, 43, 1 (2009).

Bellingham, Julie C. "The Office of Treaty Settlements: An Historiographical Study of the Historical Accounts, Acknowldgements and Apologies Written by the Crown, 1992 to 2003." MA thesis, Victoria University of Wellington, 2006.

Boast, Richard. "New Zealand Maori Council V Attorney-General: The Case of the Century?". New Zealand Law Journal (August 1987).

. The Native Land Court: A Historical Study, Cases and Commentary, 18621887, Auckland: Thomson Reuters, 2013.

.and Richard Hill (eds.), Raupatu: The Confiscation of Māori Land, Wellington: Victoria University Press, 2009

Bolger, Jim. A View From the Top, Auckland: Viking Press, 1998.

Bönisch-Brednich, Brigitte and Richard S. Hill. "Fitting Aotearoa into New Zealand:

Politico-Cultural Change in a Modern Bicultural Nation." in Manfred Berg and Bernd Schaefer (eds), Historical Justice in International Perspective: How Societies Are Trying to Right the Wrongs of the Past, New York: Cambridge University Press, 2009.

Boston, Jonathon. "Reorganizing the Machinery of Government: Objectives and Outcomes." in J. Boston, J. Martin, J. Pallot, P. Walsh (eds), Reshaping the State: New Zealand's Bureaucratic Revolution, Auckland: Oxford University Press, 1991.

and Martin Holland, (eds.). The Fourth Labour Government: Politics and Policy in New Zealand (Second Edition). Auckland: Oxford University Press, 1992. 
Brookfield, Jock. Waitangi and Indigenous Rights: Revolution, Law and Legitimation, Auckland: Auckland University Press, 1999

Butterworth, G.V. and H.R. Young, Maori Affairs: A Department and the People Who Made It, Wellington: Government Printing Office, 1990.

Byrnes, Giselle. The Waitangi Tribunal and New Zealand History, Auckland: Oxford University Press, 2004

.'By Which Standards? History and the Waitangi Tribunal: A Reply,' New Zealand Journal History, 40, 2 (2006)

."Jackals of the Crown? Historians and the Treaty Claims Process." in Bronwyn Dalley and Jock Phillips (eds.), Going Public: The Changing Face of New Zealand History, Auckland: Auckland University Press, 2001.

_. (ed.), The New Oxford History of New Zealand, Oxford: Oxford University Press, 2009.

Christie, Walter. Treaty Issues. Christchurch: Wyvern Press, 1997. A Race Apart, Auckland: Wyvern Press, 1998.

Clark, Margaret (ed.). The Bolger Years: 1990-1997, Wellington: Dunmore Press, 2008.

Coates, Ken S. A Global History of Indigenous Peoples: Struggle and Survival, New York: Palgrave Macmillan, 2004.

. and P. G. McHugh (eds.). Living Living Relationships, Kōkiri Ngātahi: The Treaty of Waitangi in the New Millenium, Wellington: Victoria University Press, 1998.

_. "International Perspectives on Relations with Indigenous Peoples." in Ken S. Coates \& P.G. McHugh (eds.), Living Relationships, Kōkiri Ngātahi: The Treaty of Waitangi in the New Millenium, Wellington: Victoria University Press, 1998.

Cowie, Dean. "The Treaty Settlement Process." in Nicola R Wheen and Janine Hayward (eds.), Treaty of Waitangi Settlements, Wellington: Bridget Williams Books, 2012.

Coxhead, Craig. "Where Are the Negotiations in the Direct Negotiations of Treaty Settlements?". Waikato Law Review 10 (2002).

Crocker, Therese. "Mandating Matters: Maori Representation and Crown Policy in the Early Treaty Settlements Processes, 1988-1998." Treaty Research Series, Treaty of Waitangi Research Unit, Victoria University of Wellington (2013). 
.Principles for Crown Action on the Treaty of Waitangi, 1989, (Historical dcoument series), Wellington: Treaty of Waitangi Research Unit, 2011.

. "Reconciliation and Resolution: The Office of Treaty Settlements and the Treaty of Waitangi Claims Process in New Zealand/Aotearoa." in Peter Adds, Brigitte Bönisch-Brednich, Richard S Hill and Graeme Whimp (eds.), Reconciliation, Representation and Indigeneity: 'Biculturalism' in Aotearoa, Universitätsverlag Winter, 2016 (forthcoming).

Cunnigham, Michael. 'Saying Sorry: the Polictics of Apology,' The Political Quarterly, v. 70, 1999.

Diamond, Paul. A Fire in Your Belly: Māori Leaders Speak, Wellington: Huia, 2003.

Durie, Edward Taihakurei. "Welcome." in Geoff McLay (ed.), Treaty Settlements: The Unfinished Business, Wellington: NZ Institute of Advanced Legal Studies and Victoria University of Wellington Law Review, 1995.

and Gordon S Orr. "The Role of the Waitangi Tribunal and the Development of a Bicultural Jurisprudence." New Zealand Universities Law Review 14, no. 1 (June 1990): 62-81.

. "Waitangi 6 February 1989." in Vincent O’Malley, Bruce Stirling and Wally Penetito (eds.), The Treaty of Waitangi Companion: Māori and Pākehā from Tasman to Today, Auckland: Auckland University Press, 2010.

Durie, M.H. "Proceedings of a Hui Held at Hirangi Marae Turangi." in Geoff McLay (ed.), Treaty Settlements: The Unfinished Business, Wellington: NZ Institute of Advanced Legal Studies and Victoria University of Wellington Law Review, 1995.

_. Te Māna, Te Kawanatanga: The Politics of Māori Self-Determination. Auckland: Oxford University Press, 1998.

—_. Ngā Tai Matatū: Tides of Māori Endurance. Melbourne: Oxford University Press, 2006.

Edmunds, D. A. and R. P. Boast "How Negotiations for Reconciliation Can Exacerbate Division as Well as Promote Reconciliation." in Reconciliation, Representation and Indigeneity: An international conference hosted by University of Mainz and Victoria University of Wellington. Wellington, March 2013.

Fisher, Martin. "Balancing Rangatiratanga and Kawanatanga: Waikato-Tainui and Ngāi Tahu's Treaty Settlement Negotiations with the Crown." PhD Thesis, Victoria University of Wellington, 2015.

. "Defenders of the Environment: Third-Party Interests and Crown-Ngāi Tahu Treaty Settlement Negotiations." Treaty Research Series, Treaty of Waitangi Research Unit, Victoria University of Wellington (2015). 
Frame, Alex. "Raupatu Settlement - Legal Finality and Political Reality." in Richard Boast and Richard S. Hill (eds.), Raupatu: The Confiscation of Maori Land, Wellington: Victoria University Press, 2009.

"A State Servant Looks at the Treaty." New Zealand Universities Law Review 14, no. 1 (June 1990): 82-96.

Gardiner, Wira. Return to Sender: What Really Happened at the Fiscal Envelope Hui. Auckland: Reed Publishing (NZ) Ltd, 1996.

Gibbs, Meredith. "Are New Zealand Treaty of Waitangi Settlements Achieving Justice? : The Ngāi Tahu Settlement and the Return of Pounamu." PhD Thesis, Otago University, 2002.

Graham, Douglas. Trick or Treaty? Wellington: Institute of Policy Studies, 1997.

"Address by the Minister in Charge of Treaty of Waitangi Negotitaions ". in Geoff McLay (ed.). Treaty Settlements: The Unfinished Business, Wellington: NZ Institute of Advanced Legal Studies and Victoria University of Wellington Law Review, 1995.

. "The Treaty and Treaty Negotiations." in Margaret Clark (ed.). The Bolger Years: 1990-1997, Wellington: Dunmore Publishing, 2008.

Hamer, Paul. "A Quarter-Century of the Waitangi Tribunal: Responding to the Challenge." in Janine Hayward and Nicola R Wheen (eds.). The Waitangi Tribunal:Te Roopu Whakamana I Te Tiriti O Waitangi, Wellington: Bridget Williams Books, 2004.

Harris, Aroha. Hikoi: Forty Years of Maori Protest. Wellington: Huia, 2004.

Harris, Rachael. "The Changing Face of Co-Governance in New Zealand - How are Ngāi Tahu and Ngāi Tūhoe promoting the interests of their people through power-sharing arrangements in resource anagement?" MA thesis, University of Canterbury, 2015.

Hayward, Janine and Nicola R. Wheen (eds.), The Waitangi Tribunal: Te Roopu Whakamana I Te Tiriti O Waitangi, Wellington: Bridget Williams Books, 2004.

."Flowing from the Treaty's Words: The Principles of the Treaty of Waitangi ". in Janine Hayward and Nicola R Wheen (eds.), The Waitangi Tribunal: Te Roopu Whakamana I Te Tiriti O Waitangi, Wellington: Bridget Williams Books, 2004.

"In Search of a Treaty Partner: Who, or What, Is the Crown?" PhD Thesis, Victoria University of Wellington, 1995.

Hickey, Maureen. "Apologies in Treaty Settlements." in Nicola R Wheen and Janine Hayward (eds), Treaty of Waitangi Settlements, Wellington: Bridget Williams Books, 2012. 
"Negotiating History: Crown Apologies in Historical Treaty of Waitangi Settlements." in Gabrielle Maxwell and James H Liu (eds.), Restorative Justice and Practices in New Zealand: Towards a Restorative Society, Wellington: Victoria University Press, 2007.

Higgins, Rawinia. "Te Wharehou O Tūhoe: The House That 'We' Built." Māori Law Review, October 2014, 7-12.

Hill, Richard.S. State Authority, Indigenous Autonomy in New Zealand/Aotearoa 1900-1950. Wellington: Victoria University Press, 2004.

Autonomy and Authority: Rangatiratanga and the Crown in Twentieth Century New Zealand: An Overview. Wellington: Crown Forestry Rental Trust, 2000.

_- "Historical 'Facts' and the Waikato Raupatu Claims Settlement Act 1995." Treaty Research Series, Treaty of Waitangi Research Unit, Treaty of Waitangi Research Unit, Victoria University of Wellington (2014).

. "A Quarter Century of Treaty of Waitangi Reconciliation Processes, 19882013: An Appraisal." in Peter Adds, Brigitte Bönisch-Brednich, Richard S Hill and Graeme Whimp (eds.), Reconciliation, Representation and Indigeneity: 'Biculturalism' in Aotearoa, Universitätsverlag Winter, 2016 (forthcoming).

-Anti-Treatyism and Anti-Scholarship: An Analysis of Anti-Treatyist Writings, (Occasional papers series) Wellington: Treaty of Waitangi Research Unit, 2002.

- Maori and the State: Crown-Maori Relations in New Zealand/Aotearoa, 1950-2000. Wellington Victoria University Press, 2009.

Jackson, Moana. "Comment." in Geoff McLay (ed.), Treaty Settlements: The Unfinished Business, Wellington: NZ Institute of Advanced Legal Studies and Victoria University of Wellington Law Review, 1995.

Joseph, Robert. "Unsettling Treaty Settlements: Contemporary Māori Identity and Represntation Challenges." in Nicola R Wheen and Janine Hayward (eds), Treaty of Waitangi Settlements, Wellington: Bridget Williams Books, 2012.

Kawharu, I.H. Maori Land Tenure: Studies of a Changing Institution. Oxford: Oxford university Press, 1977.

Kelsey, Jane. A Question of Honour? Labour and the Treaty 1984-1989. Wellington: Allen and Unwin, 1990.

. Rolling Back the State: Privatisation of Power in New Zealand/Aotearoa. Wellington: Bridget Williams Books Ltd, 1993.

Macduff, Ian. "The Role of Negotiation: Negotiated Justice?". in Geoff McLay (ed.), Treaty Settlements: The Unfinished Business, Wellington: NZ Institute of 
Advanced Legal Studies and Victoria University of Wellington Law Review, 1995.

Mahuika, Nēpia, 'New Zealand History is Māoro History: Tikanga as the Ethical Foundation of Historical Scholarship in Aotearoa New Zealand. New Zealand Journal of History, 491 (2015)

Mahuta, Robert Te Kotahi. "Tainui: A Case Study of Direct Negotiation." in Geoff McLay (ed.), Treaty Settlements: The Unfinished Business, Wellington: NZ Institute of Advanced Legal Studies and Victoria University of Wellington Law Review, 1995.

Marr, Cathy. Crown Policy Towards Major Crown-Iwi Claim Agreements of the 1940s and 1950s: A Preliminary Report for the Treaty of Waitangi Policy Unit. (Historical document series), Wellington: Treaty of Waitangi Research Unit, 2010.

McAloon, Jim. "By Which Standards? History and the Waitangi Tribunal." New Zealand Journal of History 40, 2 (2006).

McCan, David. Whatiwhatihoe: The Waikato Raupatu Claim. Wellington: Huia, 2001.

McDowell, Tiopira. “Ka Hoki A Kupe?': The Political Career of Matiu Rata, 19631979.' New Zealand Journal of History 491 (2015)

McHugh, P G. The Māori Magna Carta: New Zealand law and the Treaty of Waitangi. Auckland: Oxford University Press, 1991

_. "Sealords and the Sharks: The Maori Fisheries Agreement 1992." New Zealand Law Journal (October 1992).

. "From Soverignty Talk to Settlement Time: The Consitutional Setting of Māori Claims in the 1990s." in Paul Havemann (ed.), Indigenous Peoples' Rights in Australia, Canada, and New Zealand, Auckland: Oxford University Press, 1999.

.and Lisa Ford. "Settler Sovereignty and the Shapeshifting Crown." in Lisa Ford and Tim Rowse (eds.), Between Indigenous and Settler Governance, New York: Routledge, 2013.

McKinnon, Malcolm. Treasury: The New Zealand Treasury 1840-2000. Auckland: Auckland University Press, 2003.

McLay, Geoff, (ed.). Treaty Settlements: The Unfinished Business, Wellington: NZ Institute of Advanced Legal Studies and Victoria University of Wellington Law Review, 1995.

Mead, Hirini Moko. Tikanga Māori : Living by Māori Values, Wellington: Huia, 2003. 
Melvin, Geoff. "The Jurisdiction of the Waitangi Tribunal." in Janine Hayward and Nicola R Wheen(eds.), The Waitangi Tribunal: Te Roopu Whakamana I Te Tiriti O Waitangi, Wellington: Bridget Williams Books, 2004.

Metge, Joan and Patricia Kinloch. Talking Past Each Other: Problems of CrossCultural Communications. Wellington: Victoria University Press, 1984.

Mikaere, Annie. "Settlement of Treaty Claims: Full and Final, or Fatally Flawed?". New Zealand Universities Law Review 17, no. 4 (1997): 425-55.

Moon, Paul. The Sealord Deal, Palmerston North: Campus Press, 1999.

Morrow, Jenny Carlyon \& Diana. Changing Times: New Zealand since 1945, Auckland: Auckland University Press, 2013.

Mutu, Margaret. The State of Māori Rights. Wellington: Huia, 2011

_. "'The Sea I Never Gave': Fisheries Settlements." in Nicola R Wheen and Janine Hayward (eds.), Treaty of Waitangi Settlements, Wellington: Bridget Williams Books, 2012.

New Zealand Labour Party,. Jobs. Growth. Health: Labour's Manifesto for New Zealand 1993, Wellington: GP Publications Ltd, 1993.

New Zealand National Party. Manifesto '93: Stepping out on the Path to 2010: The Spirit of Recovery, Wellington: New Zealand National Party, 1993.

National Party Policies for the 1990s: Creating a Decent Society, Wellington: New Zealand National Party 1990.

Ngāi Tahu Negotiating Group. Te Karaka Special Edition: Crown Settlement Offer. Consultation Document from the Ngāi Tahu Negotiating Group, Christchurch: Ngāi Tahu Publications Ltd, 1997.

O'Regan, Tipene. "A Ngai Tahu Perspective on Some Treaty Questions" in Geoff McLay (ed.), Treaty Settlements: The Unfinished Business, Wellington: NZ Institute of Advanced Legal Studies and Victoria University of Wellington Law Review, 1995.

_. "Readying the Canoe on the Beach." in Roslie Capper, Amy Brown and Witi Ihimaera (eds.), Vision Aotearoa: Kaupapa New Zealand, Wellington: Bridget Williams Books, 1994.

O'Malley, Vincent. Beyond the Imperial Frontier: the Contest for Colonial New Zealand. Wellington: Bridget Williams Books, 2014

O'Sullivan, Dominic. Beyond Biculturalism: The Politics of an Indigenous Minority, Wellington: Huia, 2007.

Oliver, W.H. Claims to the Waitangi Tribunal, Wellington: Waitangi Tribunal Division, Department of Justice, 1991. 
—_. 'A reply to Jim McAloon', New Zealand Journal of History, 41, 1 (2007)

_. "Getting Facts on Your Side", New Zealand Books, December 1995, 15.

Orange, Claudia. An Illustrated History of the Treaty of Waitangi, Wellington Bridget Williams Books Ltd, 2004.

—. The Treaty of Waitangi, Wellington: Bridget Williams Books, 2011.

Palmer, Geoffrey. New Zealand's Constitution in Crisis: Reforming Our Political System, Dunedin: John Mclndoe, 1992.

_. "The Treaty of Waitangi - Principles for Crown Action", Victoria University of Wellington Law Review 19 (1989): 335-45.

Palmer, Matthew S. R. The Treaty of Waitangi in New Zealand's Law and Constitution, Wellington: Victoria University Press, 2008.

Peters, B. Guy and Donald J. Savoie (eds.). Taking Stock: Assessing Public Sector Reforms, Montreal: McGill-Queens University Press, 1998.

Phillips, Jock. "Of Verandahs and Fish and Chips and Footie on Saturday Afternoon: Reflections on 100 Years of New Zealand Historiography." New Zealand Journal of History 24, 2 (1990).

Pihama, Leonie (ed.), the Fiscal Envelope: economics, politics and colonnisation, Vol.1. Auckland: Moko Productions, 1995.

Price, Richard T. "Assessing Modern Treaty Settlements: New Zealand's 1992 Treaty of Waitangi (Fisheries Claims) Settlement and Its Aftermath." Christchurch: Macmillan Brown Centre for Pacific Studies, 1996.

Richardson, Ruth. Making a Difference, Christchurch: Shoal Bay Press, 1995.

Rigby, Barry. "Forty Years On: A Personal View of the History of the Waitangi Tribunal, 1975-2015" in Peter Adds, Brigitte Bönisch-Brednich, Richard S Hill and Graeme Whimp (eds.), Reconciliation, Representation and Indigeneity: 'Biculturalism' in Aotearoa, Universitätsverlag Winter, 2016 (forthcoming).

Riseborough, Hazel. Days of Darkness: Taranaki 1878 -1884 (rev ed.), Wellington: Penguin Books, 2002.

Ross, R.M. "Te Tiriti O Waitangi: Texts and Translations." New Zealand Journal of History 6, 2 (1972).

Ruru, Jacinta, ed. 'In Good Faith' Symposium Proceedings Marking the 20th Anniversary of the Lands Case, Dunedin: New Zealand Law Foundation and Faculty of Law, University of Otago, 2008.

Salmond, Anne. Hui: A Study of Maori Ceremonial Gatherings. Auckland: Reed Books, 1994. 
Scott, Stuart C. The Travesty of Waitangi: Towards Anarchy, Dunedin: Campbell Press, 1995.

—. Travesty after Travesty, Christchurch: Certes Press, 1996.

Sharp, Andrew. Justice and the Māori: Māori Claims in New Zealand Political Argument in the 1980s, Auckland: Oxford University Press, 1990.

- Justice and the Māori: The Philosophy and Practice of Māori Claims in New Zealand since the 1970s (Second Edition), Oxford: Oxford University Press, 1997.

Smith, Linda Tuhiwai. Decolonizing Methodologies: Research and Indigenous Peoples, Dunedin: Otago University Press, 1999

Sorrenson, M.P.K. "Towards a Radical Reinterpretation of New Zealand History: The Role of the Waitangi Tribunal." in I.H. Kawharu (ed.), Waitangi: Maori and Pakeha Perspectives on the Treaty of Waitangi, Auckland: Oxford University Press, 1989.

Stevens, Michael. 'A 'Useful' Approach to Māori History', New Zealand Journal of History 491 (2015).

Taylor, Louise. 'The Fiscal Envelope: A manifesto for finality.' LL.B (hons.), Victoria University of Wellington, 1995.

Teitel, Ruti G. Transitional Justice, Oxford: Oxford University Press, 2000.

Temm, Paul. The Waitangi Tribunal: The Conscience of a Nation, Auckland: Random Century, 1990.

Veracini, Lorenzo. Negotiating a Bicultural Past: An Historical 'Revolution' in 1980s Aotearoa/New Zealand. (Occasional papers series) Wellington: Treaty of Waitangi Research Unit, 2001.

Walker, Ranginui. Ka Whawhai Tonu Matou: Struggle without End, Auckland: Penguin, 1990.

. Ka Whawhai Tonu Matou: Struggle without End (rev. ed.), Auckland: Penguin Books, 2004.

Ward, Alan. A Show of Justice: Racial 'Amalgamation' in Ninteenth Century New Zealand, Canberra: Australian National University Press, 1974.

-A Show of Justice Racial 'Amalgamation' in Nineteenth Century New Zealand (rev. ed.), Auckland: Auckland University Press, 1995.

An Unsettled History: Treaty Claims in New Zealand Today, Wellington: Bridget Williams Books, 1999. 
- National Overview: Rangahaua Whanui Series. 3 volumes, Wellington: Waitangi Tribunal, 1997.

Wards, Ian. The Shadow of the Land: a study of British policy and racial conflict in New Zealand 1832-1852, Wellington: Department of Internal Affairs, 1968.

Wethey, Emma. "The Politics of Apology: Issues Arising from State Apologies to Indigenous Peoples for Historical Injustices in Australasia and North America." MA thesis, University of Cambridge, 2002.

Wheen, Nicola R. and Janine Hayward. "The Meaning of Treaty Settlements and the Evolution of the Treaty Settlement Process." in Nicola R Wheen and Janine Hayward (eds.), Treaty of Waitangi Settlements, Wellington: Bridget Williams Books, 2012.

Williams, David. "Honouring the Treaty of Waitangi - Are the Parties Measuring Up?". Murdoch University Electronic Journal of Law 9, no. 3 (2002)

Perspective." New Zealand Universities Law Review 14, no. 1 (June 1990): 936.

Williams, Joseph. "Landmarks: 40 Years of the Treaty of Waitangi Act 1975", Presentation." Victoria University of Wellington, 12 October 2015.

_- "Speech." in 25th Anniversary of the Waitangi Tribunal conference. Wellington, 11 October 2000.

Williams, Te Rangimārie. "Te Mana Motuhake O Tūhoe" MA thesis, Victoria University of Wellington, 2010.

Wilson, Margaret and Anna Yeatman (eds.), Justice and Identity: Antipodean Practices. Wellington: Bridget Williams Books, 1995

Wishart, lan. The Great Divide: The Story of New Zealand and Its Treaty, Auckland: Howling at the Moon, 2012. 